
$A^{2}$ 
Digitized by the Internet Archive in 2007 with funding from Microsoft Corporation 


\title{
THE ROMAN COMAGMATIC REGION
}

\author{
BY \\ HENRY S. WASHINGTON
}
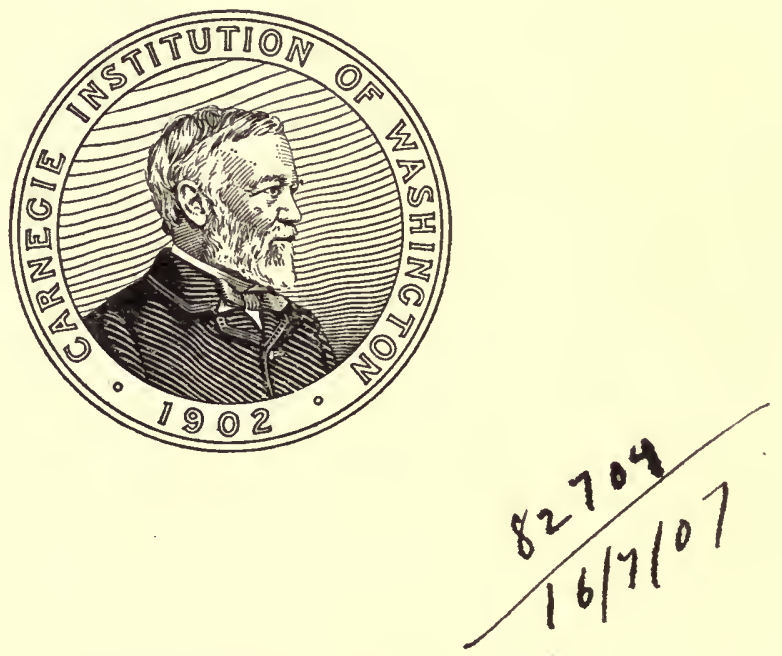

WASHINGTON, D. C.

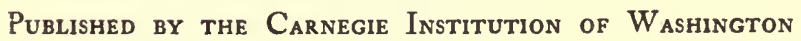
1906 


\section{CARNEGIE INSTITUTION OF WASHINGTON}

Publication No. 57

PRINTED AT THE UNIVERSITY OF CHICAGO PRESS, CHICAGO 
CONTENTS.

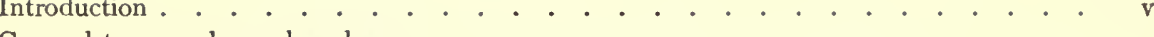

General topography and geology . . . . . . . . . . . . . . . . . . I

Vulsinian District . . . . . . . . . . . . . . . . . . 3

Ciminian District . . . . . . . . . . . . . . . . . . 5

Sabatinian District . . . . . . . . . . . . . . . . . . . 5

Latian District . . . . . . . . . . . . . . . . . . . 6

Hernican District . . . . . . . . . . . . . . . . . . . 7

Auruncan District . . . . . . . . . . . . . . . . . . . 7

Campanian District . . . . . . . . . . . . . . . . 8

Petrography . . . . . . . . . . . . . . . . . . . . . . . . 9

Introduction . . . . . . . . . . . . . . . . . . . . . . . . 9

Chemical analyses . . . . . . . . . . . . . . . . . . 10

Classification . . . . . . . . . . . . . . . . . . . . . . . I I

Descriptions and names of the rocks . . . . . . . . . . . . . . . I2

The formal descriptions . . . . . . . . . . . . . . . . . . . I5 $_{5}$

Transitional types . . . . . . . . . . . . . . . . . . 17

Determination of minor constituents . . . . . . . . . . . . . . $\quad$ r8

Ischial nordmarkose-phlegrose [augite-trachyte] . . . . . . . . . . . . . I9

Cumal phlegrose [phonolitic trachyte] . . . . . . . . . . . . . . . . 22

Rotaral phlegrosc [trachyte obsidian] . . . . . . . . . . . . . 27

Bolsenal vulsinose [vulsinite]. . . . . . . . . . . . . . . . . . . . 30

Viterbal vulsinose [leucite-trachyte] . . . . . . . . . . . . . . . . . 34

Pallanzanal vulsinose [leucite-trachyte] . . . . . . . . . . . . . . 40

Paglial procenose-pulaskose [leucite-trachyte] . . . . . . . . . . . . . . 4 I

Sabatinal becmerose [leucite-phonolite] . . . . . . . . . . . . . . . . $4^{6}$

Tavolatal janeirose-appianose [leucite-tephrite, tavolatite]. . . . . . . . . . 50

Sorianal harzose [biotite-latite] . . . . . . . . . . . . . . . 54

Arsal vulsinose-ciminose [vulsinite] . . . . . . . . . . . . . . . 58

Fiescolal ciminose [ciminite] . . . . . . . . . . . . . . . . . 62

Bagnoreal ciminose [leucite-trachyte] . . . . . . . . . . . . . . . 67

Martinal vicose-ciminose [leucite-tephrite] . . . . . . . . . . . . . . 7 I

Arsal monzonose [vulsinite] . . . . . . . . . . . . . . . . . . . . 74

Foglianal ciminose-auruncose [leucite-tephrite] . . . . . . . . . . . . . . 79

Teanal ciminose-auruncose [leucite-trachyte] . . . . . . . . . . . . . 82

Orvietal auruncose [leucite-tephrite] . . . . . . . . . . . . . . . 85

Monfinal shoshonose [biotite-latite] . . . . . . . . . . . . . . . . 88

Foglianal vicose [leucite-tephrite] . . . . . . . . . . . . . . . . . . 9 9

Bagnoreal vicose [leucite-tephrite] . . . . . . . . . . . . . . . . 96

Orvietal vicose [leucite-tephrite] . . . . . . . . . . . . . . . . . 100

Vesbal braccianose [leucite-tephrite] . . . . . . . . . . . . . . . . . 103

Sommal braccianose [leucite-tephrite] . . . . . . . . . . . . . . . 107

Galeral braccianose [leucitite] . . . . . . . . . . . . . . . . ro8

Hernical braccianose [leucitite] . . . . . . . . . . . . . . . . . . . I I I

Atrial braccianose [leucite-tephrite] . . . . . . . . . . . . . . . . . II5

Scalal vesuvose-braccianose [lcucite-tephrite] . . . . . . . . . . . . . . II7 
Romal vesuvose [leucitite] . . . . . . . . . . . . . . . .

Galeral albanose-jugose [leucitite] . . . . . . . . . . . . . . . I23

Fiordinal fiasconose [leucite-basanite] . . . . . . . . . . . . I26

Romal albanose [leucitite] . . . . . . . . . . . . . . . . . I30

Saccal albanose [leucitite] . . . . . . . . . . . . . . . . . . I33

Boval albanose [melilitic leucitite, cecilite] . . . . . . . . . . . . . . I38

Correlation of types . . . . . . . . . . . . . . . . . . . . I4I

Petrology . . . . . . . . . . . . . . . . . . . . . . . . . . . I44

Geologic occurrence . . . . . . . . . . . . . . . . . . . . . 144

Chemical characters . . . . . . . . . . . . . . . . . . I45

Normative characters . . . . . . . . . . . . . . . . . . I5I

Relations of norm and mode . . . . . . . . . . . . . . . . . . . . 154

Mineralogical characters . . . . . . . . . . . . . . . . I55

Soda-orthoclase . . . . . . . . . . . . . . . . I56 $^{\circ}$

Soda-lime feldspar . . . . . . . . . . . . . . . . ${ }_{156}$

Leucite . . . . . . . . . . . . . . . . . . . . . I57

Nephelite. . . . . . . . . . . . . . . . . . . . . . 157

Sodalite and haüyne . . . . . . . . . . . . . . . . . . I57

Augite . . . . . . . . . . . . . . . . . . . . . I57

Hypersthene . . . . . . . . . . . . . . . . . . ${ }_{15}^{8}$

Biotite . . . . . . . . . . . . . . . . . . . ${ }_{15} 8$

Olivine . . . . . . . . . . . . . . . . . . . . ${ }_{5} 8$

Melilite . . . . . . . . . . . . . . . . . . . . . . I59

Absence of minerals . . . . . . . . . . . . . . . . . . . . I59

Textural characters . . . . . . . . . . . . . . . . . . . . . . . I59

Space relations . . . . . . . . . . . . . . . . . . . . . . . . . I60

Vulsinian District . . . . . . . . . . . . . . . . . . I6I

Ciminian District . . . . . . . . . . . . . . . . . . . I62

Sabatinian District . . . . . . . . . . . . . . . . I I63

Latian District . . . . . . . . . . . . . . . . . . I64

Hernican District . . . . . . . . . . . . . . . . . I $6_{4}$

Auruncan District . . . . . . . . . . . . . . . . . . I64

Campanian District . . . . . . . . . . . . . . . . . I65

Distribution of magmas . . . . . . . . . . . . . . . . . 166

Progression of types . . . . . . . . . . . . . . . . . . 169

The rocks of the Tuscan Region . . . . . . . . . . . . . . . I I0

Quantitative relations . . . . . . . . . . . . . . . . I I

Quantitative relations of the magmas . . . . . . . . . . . I72 $^{\circ}$

The average magma . . . . . . . . . . . . . . . . . I73

Time relations . . . . . . . . . . . . . . . . . . . . . I75

Geologic age of the eruptions . . . . . . . . . . . . . . I75

Order of succession of the types. . . . . . . . . . . . . I76

Comparison with other regions . . . . . . . . . . . . . . . . . I77

The formation of leucite . . . . . . . . . . . . . . . . . . . ${ }_{I} 8_{I}$

The Roman Region . . . . . . . . . . . . . . . . . . . . I $8 \mathrm{I}$

Conclusions . . . . . . . . . . . . . . . . . . . . . . . I85

The distribution of barium . . . . . . . . . . . . . . . . . . . . . . . . 188

Bibliography . . . . . . . . . . . . . . . . . . . . . . . . 192

Index . . . . . . . . . . . . . . . . . . . . . . . . . . . . $\quad$. 195 


\section{INTRODUCTION.}

The present paper embodies the results of an investigation undertaken under the auspices of the Carnegie Institution of Washington, and is the continuation and completion of some studies which were published several years ago. Since the first publications much additional material has been collected, and, while my collections do not pretend to be exhaustive or complete, the specimens are so numerous and are regarded as so representative of the rocks of the region that they may properly serve as a basis for some general discussion.

One of the objects of the paper is the detailed description of the many rare rock types characterized by the presence of leucite, for which the Italian volcanoes are so famous, and most of which are very inadequately known. It was thought also that a careful chemical study of these, as well as of the accompanying non-leucitic rocks, might throw some light on the magmatic and physical conditions which are involved in and control the formation of this rare and interesting mineral.

Another aim was the description and discussion of the characters of the region as a whole, as an addition to the small but growing list of petrographic provinces which are more or less adequately known in their petrological and petrographical aspects. The study of these would seem to have important bearings on some of the broader problems of petrology, especially the theory of differentiation and the question of the original homogeneity or heterogeneity of the earth. As regards these we are still in the observing and fact-collecting stage of the science, and it was thought that the description of the region from the petrological, as well as from the petrographical, point of view would be of some value.

In this connection attention may be called to the introduction of the term "comagmatic region" to replace the older "petrographical province." It is thought that the latter is unsatisfactory in that it implies only the purely petrographical characters, without reference to the broader petrological characters and relations (of which the petrographical are but one set), the knowledge of which is essential to our understanding of a given area of genetically related rocks as a whole. Furthermore, the term "province" implies that the area is part of a larger one, and, while this may ultimately be found to be true in some instances, it would seem better to employ some term which does not have this connotation and which does not postulate in the term itself any relations to others.

It may be objected to the word "comagmatic" that it begs the question of common genetic origin for the rocks of a given region. But the word is used merely with the idea that the magmas of a certain area have characteristics in common, which is the idea underlying the use of "petrographical province," and whether the occurrence of these common characters is due to processes of magmatic differentiation or to other causes is not asserted or implied in the term.

In the case of the present region, as in many others, it will be found that it is naturally divisible into smaller groups, around clustered or single centers of intru- 
sion or eruption. For these the term "district" is used, the individual points from which the igneous rocks were extruded being called "centers."

Advantage was also taken of this opportunity to illustrate some of the practical applications to the study of rocks of the principles of the new classification and nomenclature, and to test their value in petrological investigations. Such an exposition was especially needed in the matter of types and the use of the proposed rock names. In recent literature a number of petrographers have employed the classification so far as to give the magmatic position of the various rocks dealt with. But the system, to be a practical one, as it is intended to be, must go farther than this, and its rock names and other parts of its nomenclature must be capable of use in descriptive literature, just as are those of the prevailing systems.

No apology is therefore offered for the language in which part of the paper is couched, nor for the unfamiliar terms employed throughout. On the contrary, it is hoped that their use here will aid petrographers to a better understanding of the quantitative system, and that the paper will serve in some sort as a working model of its methods and applications. Some of the terms which are not to be found in the original publication of the quantitative system are the result of subsequent conferences and discussions between the joint authors of that, and they, as well as further additions, are expected to appear in the Journal of Geology (vol. xIV, I906).

The whole region whose rocks are the present objects of study is being investigated with enthusiasm, especially from the geological and structural points of view, by many able Italian geologists, whose published results have been made use of largely. Some of the more important of these publications, with those of foreign observers, will be found in the bibliographical list given later. With comparatively limited opportunities to make the many detailed observations in the field which are needed to elucidate all the strictly geological questions involved in the study of the region, I can not renture to treat these adequately on the basis of my own knowledge and must leave their discussion to the geologists of the country, who have shown such zeal in the study of the many interesting problems which their favored peninsula presents. I can only express the hope that my Italian confrères will not deem me an unwelcome intruder into their proper sphere of investigation, but will consider the efforts made here to solve some of the special problems as evidence of the deep interest taken in the geology of their country, whose men of science have always shown themselves most hospitable to those from abroad.

It is a great pleasure to express my thanks to the Trustees of the Carnegie Institution of Washington, who have so generously aided me in these investigations, and have made it possible to bring to completion a long-cherished plan. To my colleagues in the quantitative classification, Doctor Cross, Professor Iddings, and Professor Pirsson, I am deeply indebted for much kind interest, advice, and aid in many ways. As one of the objects of this paper is to serve as an example of the practical application of our ideas, they have been frequently consulted, part of the manuscript has been examined and commented on by them, and the general form in which the descriptions of the types are cast is the result of our joint discussions. 


\section{THE ROMAN COMAGMATIC REGION.}

\section{GENERAL TOPOGRAPHY AND GEOLOGY. Introduction.}

The volcanoes of the Italian peninsula may be referred to several distinct comagmatic regions (petrographic provinces), the distinctions between them being based largely upon the petrographic and chemical characters of their rocks, though they are also separated by their geologic ages and their topographic and geologic relations. The most prominent of these may be enumerated as follows, and are shown in the map on the following page:

The Venetian Region, comprising the volcanic complexes of the Euganean and Berican Hills.

The Apulian Region, comprising the volcanic complex of Monte Vulture.

The Tuscan Region, comprising the volcanoes of Monte Amiata, Montecatini, Orciatico, Campiglia and Roccastrada, with which may be placed the volcanoes of Tolfa and Cerveteri, and Monti Calvario and San Vito near Bracciano.

The Roman Region, comprising the main line of volcanoes which extend from Lake Bolsena southeast to Vesuvius and the Phlegrean Fields.

All of these vary widely in the characters of their eruptive rocks, and tiffer as well in regard to their geological ages. The only one which concerns us here is the last mentioned, the Roman Region, so named from the fact that it embraces the chief territory of the ancient Roman Republic, as well as the capital city of modern Italy. These volcanoes are all of Quaternary age, the eruptions of some of them extending into historic and even modern times. Extending in a narrow line between the Apennines and the Tyrrhenian Sea, these volcanoes occupy the sites of old embayments in the Mesozoic and Tertiary sediments which form the backbone of the Italian peninsula.

It will be found convenient to take up the description of the region under the different districts into which it may be subdivided, which surround distinct centers of volcanic activity, and which are more or less clearly separated from one another. These districts are seven in number, and may be thus enumerated, the names bestowed upon them following as far as possible the usages of the Italian geologists:

(I) Vulsinian District, comprising the volcanic complex around Lake Bolsena. Named from the ancient tribe of the Vulsinii.

(2) Ciminian District, comprising the volcanoes near Viterbo. Named from the Latin appellation of Colli Ciminii.

(3) Sabatinian District, comprising the volcanic complex around Lake Bracciano. Named from the Roman name of the lake, Lacus Sabatinus. 


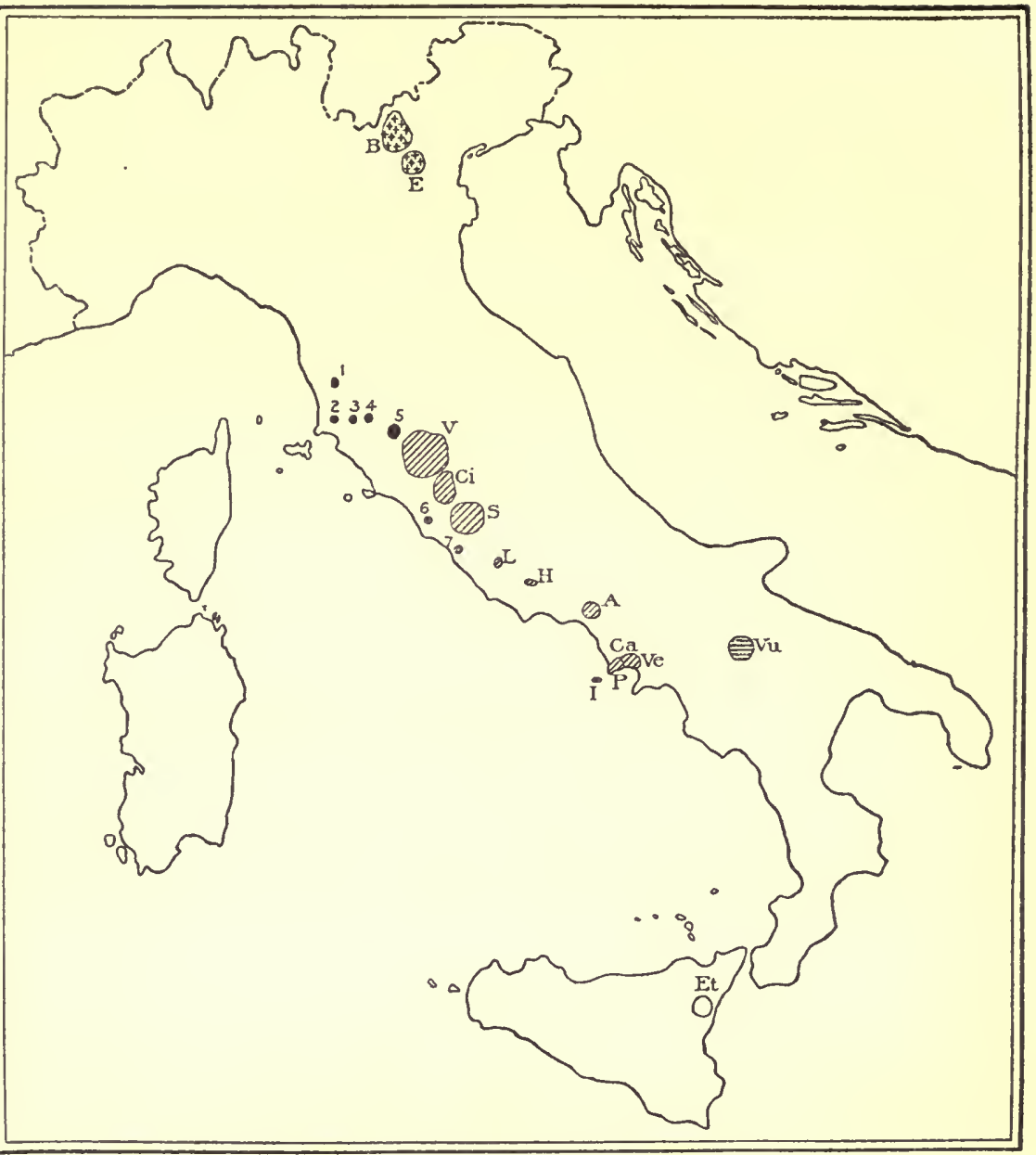

FIG. I.-Sketch map of Italian comagmatic regions.

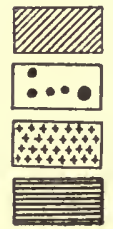

Roman Region. $\quad \begin{array}{ll}\mathrm{V}=\text { Vulsinian District. } & \text { Ve=Vesbian Volcano. } \\ \mathrm{P}=\text { Ciminian District. } & \mathrm{P}=\text { Phlegrean Fields. }\end{array}$ Tuscan Region. $\quad \begin{aligned} & \mathrm{S}=\text { Sabatinian District. } \\ & \text { L }\end{aligned}$

$I=$ Ischia.
$\mathbf{I}=$ Montecatini.

5 = Monte Amiata.

Venetian Region.

$\mathrm{H}=$ Hernican District.

$2=$ Campiglia.
3 = Massa Marittima.

7 = Cerveteri

Venetian Region. $\quad \mathrm{A}=$ Auruncan District.

Apulian Region. $\quad \mathrm{Ca}=$ Campanian District.

4 - Roccastrada.

$\mathbf{E}=$ Euganean Hills.
$\mathrm{Vu}=$ Monte Vulture.

$E_{\mathrm{t}}=E_{\text {tna }}$. 
(4) Latian District, comprising the volcanic complex of the Alban Hills near Rome. It is so called from its position in the ancient Latium.

(5) Hernican District, comprising the volcanoes in the valley of the Sacco River, formerly inhabited by the Hernici, whence the name is derived.

(6) Auruncan District, comprising the volcano of Rocca Monfina. The name is derived from the ancient tribe of the Aurunci.

(7) Campanian District, comprising the volcanoes of Vesuvius, the Phlegrean Fields, and of Ischia. It is named from the Roman province of Campania, in which it lies.

In addition there are a number of very small cones, or remains of cones, at some distance from the main line, as at Radicofani, San Venanzo, and Rieti. The rocks of these are possibly connected with those of the main line, but they will not be described, and their rocks will be only incidentally mentioned.

The relations of the volcanoes of the Roman Region to the earlier ones of the Tuscan Region, which lie rather closely to the north and west, are problematical. There is some evidence that the rocks of the two regions are connected genetically, as will be pointed out later, but it seems advisable for the present to confine our attention to the Roman Region, leaving the discussion of the volcanoes and rocks of the Tuscan Region to the future.

The brief descriptions which follow do not pretend to be complete. They serve only to give a general idea of the topography and geology and the vulcanological structure of the several districts, sufficient for a proper understanding of some of the petrological relations to be discussed in subsequent pages. They are based on the most modern literature available, which is due to the activity of the able Italian and German geologists who have studied the region, supplemented by the observations which I was able to make.

\section{Vulsinian District.}

This district, the most northerly of the zone, extends from the Paglia River on the north to the Ciminian District on the south, the boundary between the two being irregular and in places not well defined. It embraces an area of about 2,280 square kilometers, and extends in all directions around Lake Bolsena, which is the most prominent topographical feature.

The lake is quite regularly elliptical in shape, the major axis running north and south. Its dimensions are I 3 by I I kilometers, with an area of II4.5 square kilometers. The lake surface lies 305 meters above sea-level, and the bottom, with some irregularities, slopes in general toward a point near the center, where the depth is the maximum one of 146 meters. Two small islands project above the water in the southern half.

Lake Bolsena is surrounded by a girdle of hills which slope steeply down to the narrow fringing shore. These are the highest on the north, where they attain an altitude of 702 meters above sea-level, and among these are the small 
towns of San Lorenzo and Acquapendente. On the east the hills are of a fairly uniform height of 600 to $65^{\circ}$ meters, the town of Bolsena lying on the northeastern shore, and the city of Orvieto some I4 kilometers northeast of the lake, on the edge of the igneous area. The town of Montefiascone is situated on a hill (633 meters) near the southeastern corner of the lake. On the south the hills are low, uniformly less than 100 meters above the lake-level. On this shore are the villages of Marta (at the lake emissary) and Capodimonte, while I $_{5}$ kilometers to the south is the town of Toscanella. The western hills are also low, though somewhat higher than on the south, with the town of Valentano near the southwestern corner.

From this encircling crest of hills the land surface slopes down to the north, east, and west, the fall being quite regular, but somewhat diversified by the remains of cones and craters. As the rocks are to a large extent somewhat incoherent tuffs, the general topography is characterized by erosion ravines, radiating from the lake, and often leaving isolated buttes here and there.

To the west of Lake Bolsena is another, though much smaller, depression, or rather plain, surrounded by a girdle of hills, whose circle impinges on that of Lake Bolsena. In this is the small Lake Mezzano, and the whole, undoubtedly a distinct crater, is known as the Latera Volcano, from a small town on its rim. A prominent feature of this is an extensive and very rough-surfaced lava flow, now covered with forest, and known as the Selva del Lamone. Owing to bad weather I was unfortunately unable to visit the Latera Volcano, though my examination of the rest of the district was fairly complete.

The general structure of the complex (and especially the origin of Lake Bolsena) has long been the subject of dispute, and unfortunately the two geologists who have studied the district most completely (Moderni and Sabatini) do not hold the same views. According to Moderni, the Vulsinian complex has been formed by the eruptions from four principal vents-the volcanoes of Latera, Bolsena, Montefiascone, and Capodimonte-the first three being situated, respectively, on the west, northeast, and southeast, and the last being to a large extent now covered by the waters of the lake in its southern part. Each of these rolcanoes had its own smaller flanking and parasitic cones. Lake Bolsena, according to his view, is not a true crater lake, due to either the explosion or the falling in of a single large volcanic cone, but rather a lake basin formed by the accumulation of the materials ejected from the four surrounding volcanoes.

On the other hand, Sabatini regards the complex as essentially a system of concentric crater ridges and atrios, due to the gradually decreasing vulcanicity about one main central vent, of which Lake Bolsena is the crater. Superposed on the flanks of, and later than, this main volcano are the smaller ones of Latera, Bolsena, and Montefiascone, with their parasitic cones.

It is unnecessary here to weigh these two opinions, so diametrically opposed in some respects. Each represents the conclusions of an able geologist who has made a careful and profound study of the district, Moderni more especially of the western 
half, and Sabatini of the eastern. For the present, the question must be left an open one, and this is the more advisable here, since, whatever be the facts as to the origin of the topographic features and structure, they have little bearing on the predominantly petrological questions treated of in the present paper.

\section{Ciminian District.}

The Ciminian District immediately adjoins the preceding one on the north, and is bounded on the south by the Sabatinian District. Its area is approximately 900 square kilometers. It is composed of two distinct volcanoes, that of Cimino on the north and of Vico on the south, the former being the earlier.

The remains of the Cimino Volcano are made up of several hills, including Monti Pallanzana, Vitorchiano, Cigliano, and Soriano, surrounding on the west, north, and east the main mass of Monte Cimino proper, whose highest point has an altitude of $\mathrm{r}, 035$ meters above sea-level. This complex is pretty clearly the remnant of a single volcano, though the original structure is largely hidden by the extensive erosion which it has undergone and which has been much aided by the tuff-like character of most of its rocks.

Immediately to the south, or rather south-southwest, of Monte Cimino, whose southern flanks are partly covered by its ejectamenta, is the better-preserved Vico Volcano. Vico is a fairly well-preserved volcanic cone of the normal type of strato-volcano, the sides sloping up regularly (much more so than in the Vulsinian District) to the circular crest, inside which is the small, shallow Lake Vico. North of this lake is the site of the last eruption of the volcano, Monte Venere, a small hill, rising 325 meters above the lake-level, and composed of lava flows with some tuffs and lapilli. The lake surface is 507 meters above sea-level, and the steep inner wall of Vico rises from roo meters above this on the south, where it is the lowest, to 456 meters at Monte Fogliano on the west. Though the almost perfect circularity of the rim is marred by the projection of this last summit, there seems to be no doubt that the hollow is a true crater and the volcano a simple one, with few parasitic cones. The feature of radial valleys eroded in the loose surrounding tuffs is well marked in the topography of this volcano.

Of the towns which may be mentioned, the city of Viterbo lies in the angle between the two volcanoes, west of Soriano and north of Vico. About the Cimino Volcano we find the villages of Soriano on the east, Vitorchiano a short distance to the north, and Bagnaia on the northwest, while around Vico are San Martino near the northwest crater rim, Vetralla on the west, Capranica on the southern edge of the area, Ronciglione near the southeast shore of Lake Vico, and Caprarola and Canepina to the east and northeast.

\section{Sabatinian District.}

This lies immediately to the south of the Vico Volcano, with whose tuffs its own intermingle. The area covered by volcanic rocks is estimated by Moderni at 1,369 square kilometers, so that in extent it is intermediate between the Vulsinian and the 
Ciminian districts. It resembles the district first described, inasmuch as a sheet of water, Lake Bracciano, forms the topographic center. This lake, with an area of 57.5 kilometers and a depth of I60 meters, has its surface I64 meters above sealevel. It is approximately circular in shape, with two or three small bays, and is surrounded on the west and north by a girdle of hills, which attain their highest altitude above sea-level (602 meters) at Monte di Rocca Romana on the north. Immediately to the east is the small Lago di Martignano, and the basins of two others are represented in the Stracciacappa Marsh and the Valle di Baccano, all three being distinctly elliptical or circular and surrounded by rings of hills or curving ridges. From the inner wall surrounding Lake Bracciano the land slopes down to the west, north and east rather regularly, though it is broken on the west by the Tertiary volcanic masses of Monte Calvario and Monte San Vito. On the south the hills along the lake shore are lower, and the slope southward is very gentle.

The general topographic resemblance to the Vulsinian District is very marked, though the features are on a somewhat smaller scale. Moderni, who has studied this district very carefully, argues for it a structure analogous to that which he assigns to the Vulsinian. He regards Lake Bracciano as being, not a crater lake, but as a lake basin formed by the ejections of the surrounding volcanic vents, of which he enumerates and describes eight main ones, with their parasitic cones. This view is combated by Sabatini, so that, for the present, the question of the structure of the complex and the origin of the lake must be regarded as unsettled.

Of the towns in the district the most important is Bracciano, on the crest of the western lake-rim. Smaller ones are Manziana and Oriolo on the northwest, Trevignano on the northern shore, near a small semicircular bay, and Anguillara on the southeast shore near the outlet of the lake.

\section{Latian District.}

The Alban Hills, which make up this district, are situated to the southeast of Rome, as is well known, and some 50 kilometers southeast of Lake Bracciano. The area covered by the volcanic complex is about 580 square kilometers.

The complex consists of a circle of hills and summits, varying in altitude from 550 to 939 meters, and with a diameter of about 15 kilometers. Up to this the surface rises gently from the north, east, and south, while on the west and southwest the regularity of this somma is broken by the lakes Albano and Nemi and the Valle Ariccia, the sites of late flanking eruptions. Inside the large circle there rises a fairly well-defined cone, attaining a height of 956 meters and with the crater known as Campo d'Annibale at the top. Monte Cavo forms the most prominent and almost the highest point of the rim encircling this.

The structure is explained by Sabatini, who has made a careful study of the complex, as analogous to that of Somma and Vesuvius. The larger circle of hills is the crater of the earliest volcano, within which, at a later date, was thrown up the interior cone of Monte Cavo. The small lakes occupying the western slope, and 
which destroyed much of the earliest crater wall, are true crater lakes, due to later eruptions, the positions of the vents having shifted. The tuffs from this volcano have covered nearly the whole of ancient Latium.

The most important towns to be mentioned are Rocca di Papa near Monte Cavo, Grotta Ferrata, and Frascati on the northwest outer slope of the earliest cone, Rocca Priora on the northeast, and Velletri on the southeast, while Marino, Castel Gandolfo, Albano, and Genzano are all in the immediate vicinity of the small, late crater lakes on the west and southwest.

\section{Hernican District.}

This district, which lies in the valley of the Sacco, about 50 kilometers eastsoutheast of the Alban Hills, differs from those described above in two respectsthe geologic structure and the volume of the eruptive products. Instead of forming a single volcano or volcanic complex of large dimensions, the eruptions were of such small amount and the vents so widely separated that they formed only six or eight small and isolated cones. These may be called the Cones of Ticchiena (between Frosinone and Ferentino), Pofi, San Francesco, San Marco, Sant'Arcangelo, Callame (the last four around the town of Ceccano), Giuliano, Patrica, Morolo, and Selva dei Muli. Of these the one which best preserves any well-defined vestiges of its original form is that of Pofi. This village lies on a hill 295 meters above sea-level and I 30 above the Sacco Valley bottom, which is formed for the most part of tuffs and lapilli, with a few small lava flows, the crater having disappeared. The other cones have suffered so extensively from atmospheric degradation that they are now represented by areas of volcanic tuffs, with small exposures of lava here and there, and with but little trace of the original form. The total area of the volcanic products is very small-less than 50 square kilometers in all.

\section{Auruncan District.}

This district is situated about 70 kilometers southeast of the preceding one and about 65 north-northwest of Vesuvius, and its volcanic rocks cover an area of about 400 square kilometers, roughly estimated. It consists of but one volcano, which is called Rocca Monfina. This is of the simple type of strato-volcanoes, analogous to that of the Alban Hills and the Somma-Vesuvius mass, and has comparatively few parasitic cones. It possesses an external ring, sloping regularly outward on all sides and eroded into radial valleys. The crest of the ring reaches its maximum height of 926 meters above sea-level on the southwest side, which is the best preserved, the original crater walls having been much degraded, or being at least much lower, on the north and east. In the center of the plain inclosed by the large crater ring, which measures about 6 kilometers in diameter, rises the dome of Monte Santa Croce, the site of the final eruption of the volcano, with the smaller Monte Lattani adjoining it on the north.

Of the towns around this volcano, the only ones which need be mentioned are Rocca Monfina, at the east foot of Monte Santa Croce; Teano, near the southeastern 
edge of the district; Sessa Aurunca, similarly placed on the southwest; and Conca, on the northern outer slope.

\section{Campanian District.}

This district may be conveniently divided into three subdistricts-the Vesbian,* which consists of the Vesbian Volcano, a convenient appellation for the mass of Mount Vesuvius and the encircling Monte Somma; the Phlegrean, embracing the volcanoes of the Phlegrean Fields; and the Ischian, consisting of the island of Ischia.

The Vesbian Volcano is so well known and has been described so often that little need be said of it here. It consists of the older ring of Somma, which forms a half-circle open to the south, with a maximum elevation of I,I37 meters. Inside this, and slightly eccentric to the south, rises the cone of Vesuvius to a height of about I,300 meters, the product of the long series of eruptions since 79 A. D. The valley between the Somma ring and the cone of Vesuvius is called the Atrio del Cavallo.

As is well known, the Vesbian Volcano is a typical strato-volcano, composed of lava flows and interbedded tuffs, which are deeply scored by radial erosion valleys on the outer slopes of Somma. The total area covered by the eruptive products of the volcano, exclusive of the thin beds of tuff which extend to considerable distances around it, may be estimated at 300 square kilometers.

The Phlegrean Fields are only less well known than Vesuvius, and consist of numerous small volcanoes, of which Günther enumerates 26, arranged in 6 groups. The most important ones are: Pianura and Soccavo, which are among the earliest; Astroni, Olibano, Solfatara, Campiglione, Cuma, Averno, Monte Nuovo (which is the latest and was formed in I538), Monte di Procida, Capo Miseno, and the small islands of Nisida, Procida, and Vivara. None of these volcanoes is of very large size or great altitude, and they have ejected very small amounts of solid lava, the material for the most part being tuffs. The total area of the Phlegrean Fields has been estimated at about $\mathrm{r}_{3} \mathrm{O}$ square kilometers.

The island of Ischia, with an area of 46.5 square kilometers, is somewhat pyramidal in form, rising up to the summit of Monte Epomeo (792 meters), which is the ruin of the original large volcano, of the crater of which traces remain at Fontana. In large part the island, and especially the main mass of the Epomeo Volcano, is built up of tuffs, but lava flows are also to be found. Flanking the Epomeo Volcano, especially on the east and north, are several parasitic cones, of which there may be mentioned Monte Campagnano on the southeast, Castello d'Ischia on the east coast, the lava flow of L'Arso ( $\mathrm{r}_{302}$ A. D.), which, issuing from Le Cremate about half-way up the east slope of Epomeo, reaches the sea at the northeastern corner of the island, and Lago di Bagno, Montagnone, Monte Rotaro, and Monte Tabor, which lie along the north coast. The extreme northwest corner of the island is occupied by the mass of Marecocco and Zale, which may belong to the eruption of 470 B. C.

* From an ancient name of Mount Vesuvius. 


\section{PETROGRAPHY.}

\section{Introduction.}

The present section will be devoted to the purely petrographic characters, that is, to the descriptions of the rocks themselves, including their magmatic or chemical, modal or mineralogical, and textural characters. While some of the rocks dealt with are well known to all petrographers, or have been already described according to the prevailing systems, others are here discussed, at least in detail, for the first time. But in order to secure uniformity, all the types which have come under my observation will be described, irrespective of whether they have previously appeared in literature or not. This is essential, because the older descriptions, based as they are on primarily qualitative principles of classification, are inadequate for the description and discussion of the region according to the newer system. Furthermore, one of the objects of this paper being the illustration of the application of the recently proposed quantitative system, the more rocks that are described, especially if of well-known types, the better will the paper serve its purpose. The tuffs of the region will not be discussed.

As the specimens examined and the rock types to be described are very numerous, the descriptions will be as brief as may be consistent with their purpose. Minute details and certain mineral and textural peculiarities, such as the extinction angles of the feldspars and other minerals, schemes ofp leochroism, the details of zonal structure and of the arrangement and character of inclusions, etc., will either be omitted or only briefly alluded to. While undoubtedly of great value, such minutiæ belong rather to the descriptions of single specimens, and considerations of space and time would, in any case, lead to their omission here. Direct reference to previous work or observations will not often be made, but further details may be looked for in the references given in the bibliography.

On the other hand, the descriptions will be much more quantitative than has hitherto been attempted, in accordance with the fundamental principles of the classification and nomenclature adopted here. The necessity of this in the premises is apparent, but the somewhat laborious and time-consuming work involved by this method of treatment, as well as the difficulty of applying microscopical measurements to rocks of such fine grain as are many of these, have limited their application, at least in an exact way, to those rock specimens which were analyzed chemically and which serve as types. The others have been classified by reference to and comparison with these type specimens, supplemented in some necessary cases by measurements under the microscope. On this account the reference of some of the unanalyzed rocks to certain classificatory positions, or their classification, is not altogether certain. It was found, however, that practice in the comparison of rocks from the quantitative point of view, and the gradual assumption of a mental attitude of regarding them quantitatively, made the discrimination and 
decision gradually easier, so that in the final general survey of all the specimens and their thin sections there were very few cases where any change in the assigned position seemed to be justified, and few attributions which were seriously in doubt.

Chemical Analyses.

As a knowledge of the chemical composition of igneous rocks is fundamental to their classification according to the system adopted here, especial attention was paid to their chemical analysis. In the selection of appropriate specimens for this the endeavor was made to have them, as far as possible, representative of the various kinds of magma found in the region-those which are common as well as those which are of rare occurrence. Furthermore, it was attempted to have the analyses representative of as many as possible of the different magmas found in each district, so as to furnish a clue to the magmatic variations in each; and again to have analyses of some, at least, of the diverse modes and textures which each magma might assume on solidification. These various aims could not all be completely attained, some magmas being represented by many analyses, while of others equally as abundant but few were made. At the same time, the analyses here presented are so numerous, and cover such a variety of rocks of widely diverse chemical, modal, and textural characters, that they may be deemed an adequate basis for a discussion involving the chemistry of the rocks.

There exist in the literature numerous analyses of the rocks of the Roman Region, especially those of the Vulsinian and Campanian districts. Of these older analyses only a few have been found, on careful consideration, to be adequate for modern use either as regards accuracy or completeness. A large series of analyses of Vulsinian rocks are not only incomplete in the determination of minor constituents, but, as will be shown later, are so hopelessly inaccurate, especially in the figures for the alkalies, that they may all be rejected without hesitation. The older analyses of the Vesuvian lavas, while in part much more accurate in the determination of the main constituents, are faulty on the score of completeness, in the absence of determinations of the minor ones, as titanium and phosphorus. In these rocks, as is seen elsewhere, these usually negligible constituents assume a very considerable importance in classification, so that we can not avail ourselves here of this otherwise adequate and useful older work, except in a general way.

Most of the analyses made and published several years ago by myself have been incorporated, as new analyses and redeterminations have shown them to be reliable. In some cases they have been corrected by redeterminations of some of the constitutents, as well as rendered more complete by the determination of minor constituents in which they were lacking, especially titanium and phosphorus. Unless otherwise stated, this has been carried out with material remaining from the original analysis. But the majority of the analyses presented in this paper have been made by me especially for the present investigation. In making them, as well as in the determinations which were needed to bring the older analyses up to modern standards of completeness, the methods employed were those advocated by Hille- 
brand* and myself, $\uparrow$ and which long experience has shown to be reliable. In many cases the rarer and less often looked-for constituents, as baryta and zirconia, were estimated, with results which are of considerable interest. In the statements of the analyses the molecular ratios are given in a column immediately following that of the percentage amounts.

\section{Classification.}

The classification adopted here is the quantitative one recently proposed, a description of which it seems unnecessary to give. Comparatively little literature has as yet appeared expressed in the terms of the new system, and little in the way of describing or establishing types according to the suggestions made, so that the present paper may be regarded as illustrative of the practical application of the new classificatory principles and nomenclature to the actual study of rocks and the discussion of petrological problems.

It is a somewhat difficult matter for the petrographer to change his conceptions of rocks so as to conform to the new requirements and to regard rocks primarily as magmas of which they are but the solidified forms, and more especially to keep the importance of the quantitative relations constantly in mind. This has proved true in my own case, and it has required considerable effort at times to keep to the narrow and untrodden path of a quantitative system based primarily on chemical composition, and to refrain from treading the broad road, easy from much use in the past, of qualitative systems based on mineral composition and texture. To what extent this effort to adapt the mental attitude to the new requirements is successful, it will be easier for the reader than for the writer to judge.

Magmatic Divisions Represented in the Roman Region.

\begin{tabular}{|c|c|c|c|c|}
\hline Class. & ORDER. & RANG. & \multicolumn{2}{|c|}{ Subrang. } \\
\hline III. Salfemane... & 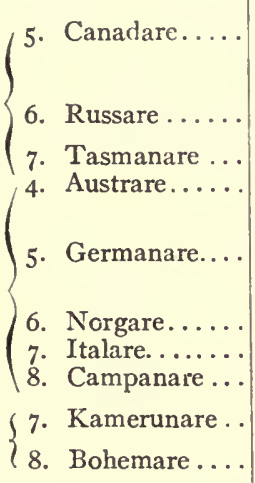 & 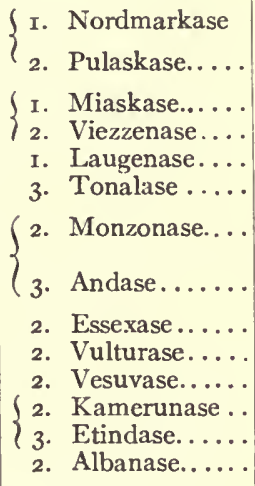 & $\begin{array}{l}\text { 3. Phlegrose, } \\
\text { 2. Vulsinose, } \\
\text { 3. Pulaskose, } \\
\text { 3. Beemerose, } \\
\text { 3. Procenose, } \\
\text { 3. Appianose, } \\
\text { 3. Harzose, } \\
\text { \{. Ciminose, } \\
\text { 3. Monzonose, } \\
\text { 2. Auruncose, } \\
\text { 3. Shoshonose, } \\
\text { 2. Vicose, } \\
\text { 2. Braccianose, } \\
\text { 2. Vesuvose, } \\
\text { 2. Jugose, } \\
\text { 2. Fiasconose, } \\
\text { 2. Albanose, }\end{array}$ & 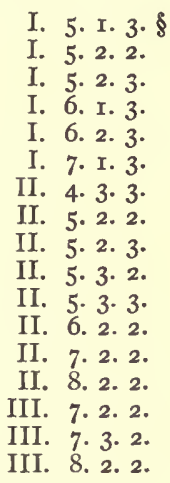 \\
\hline
\end{tabular}

* W. F. Hillebrand, Some Principles and Methods of Rock Analysis, Bull. U. S. Geol. Surv. No. 176, 1900

$\dagger$ H. S. Washington, Manual of the Chemical Analysis of Rocks, New York (I904).

$\ddagger$ Cross, Iddings, Pirsson, and Washington, Quantilative Classification of Igneous Rocks (Chicago, 1903). Cf. Journal of Geology, X (1902), pp. 555-690.

$\$$ For the explanation of these symbols to indicate the magmatic position, see H. S. Washington, Prof. Paper U. S. Geol. Surv. No. 28,1904 , p. 13. 
In the terms of the quantitative classification the preceding magmatic divisions, as far as subrang, are represented in the Roman Region. They include 3 classes, Io orders, $x_{4}$ rangs, and I7 subrangs. There are probably a few more which are not discussed in this paper, but the amounts of these are probably small, and those given here undoubtedly embrace the great majority of the most important and most abundant of the Roman magmas.

\section{Descriptions AND NaMes of Rocks.}

The rocks will be described under the heads of the various types to which they belong, a type being understood to mean a standard rock with a certain assemblage of characters, accurately and quantitatively described as regards the chemical composition, norm, mode, texture, and the textural disposition of the constituent minerals. Rocks will be considered to belong to the same type when they are quite or almost identical in these respects, so much so that they may be mistaken for one another, or might be parts of the same mass, as suggested in the publication of the Quantitative System (p. 179). As a practical matter the identity can not be absolute in all cases, and a certain amount of latitude, or very slight divergence from the type, must be allowed. Otherwise the number of types will be almost as great as the number of the occurrences or of the hand specimens collected. This latitude is only reasonable, and that it is allowable is shown by the practice in botany, where, for instance, individual plants are referred to the same species, although there are slight differences in minor and unimportant points, such as the lengths of the leaves, the heights in different habitats, etc.

The name of a rock, then, according to the quantitative system, and as applied throughout this paper, will be considered to be the type name-that is, the name of the subrang qualified by a typal adjective or one indicating the type to which the rock belongs. This typal adjective is formed according to the published suggestion by the use of a root derived from a geographical locality and the termination al. Such a name expresses as concisely as possible, and without ambiguity, or at least with only very narrow limits of variation, all the inherent characters of a rock, the subrang name indicating its chemical character and systematic position in the classification, and the type adjective its color, modal and textural characters, the textural disposition of the minerals, etc.

For the purpose of correlation with the prevailing systems, and for the benefit of those who are unacquainted or unfamiliar with the quantitative system, the names by which the rocks would be called in the prevalent nomenclature are also used throughout the paper, in brackets [ ], while the symbols of the subrang will be placed in parentheses ( ) when it is deemed advisable to add them to the quantitative rock name. But it must be remembered that these symbols do not form any part of the name, and are used only to indicate the magmatic position on account of the unfamiliarity of the new terms.

In assigning the names of the prevailing nomenclature, the usage of Zirkel in 
regard to leucite-trachyte and leucite-phonolite has been followed rather than that of Rosenbusch, for reasons discussed elsewhere. The term "leucite-trachyte," therefore, as used in this paper, implies a rock composed essentially of leucite and orthoclase, while a "leucite-phonolite" is one composed of the same two minerals with nephelite in addition, in both cases the presence of subordinate amounts of alferric and other minerals being allowed. It has sometimes been difficult to decide between two names, as, for instance, between "leucite-trachyte" and "leucitetephrite," or "leucite-tephrite" and "leucitite," as both labradorite and orthoclase may be present in the former case, or a little labradorite alone in the latter, in both cases with much leucite. In all such cases the name finally selected was based, as far as possible, on the quantitative estimation of the mode, modified in some instances by the greater prominence of one or the other mineral.

A list is appended of the various rock types which have been observed and described in the region, with their corresponding names according to the prevailing systems, so that comparison between the two may be rendered more easy. In the prevailing names I have followed the trend of some modern authors in further qualifying the broader and more common names by the use of type names. This would seem to be reasonable, as it is certainly advisable to be able to discriminate, even in the customary nomenclature, between, for instance, three such different "leucitetephrites" as those of the Viterbo type, with its large and numerous leucite phenocrysts, that of the Orvieto type, without any phenocrysts, and that of the Tavolato type, with large leucite phenocrysts, abundant haüyne, little feldspar, and very different chemical composition.

In two or three instances new names have been proposed for use in the prevailing system of nomenclature. This has been done with caution, and only in those cases where they seemed to be especially necessary or useful, on account of the peculiar chemical, mineralogical, or textural character of the type, as with the abundant and highly characteristic leucite-trachytes and leucite-tephrites with the viterboid habit marked by the numerous large leucite phenocrysts, or the peculiar leucitetephrite of Tavolato, with its abundant large haüynes and peculiar chemical composition, which has little in common with the leucite-tephrites as usually understood. In one instance an old and forgotten rock name has been revived-that of cecilite (Cordier), for the highly melilitic leucitites.

It is seen that many of the prevailing rock names cover wide variations in texture and magmatic characters - a point which will be more fully appreciated by referring to the descriptions which follow. And it is also evident that some of the subrang names are applied to rocks which differ much in their modes and textures, a consequence of the fact that the quantitative system is based primarily on the chemical composition of the rock, and that the modal and textural characters are regarded as of less importance, they being expressed by the type name. A study of the table from this point of view is very instructive, and the relation between the two systems should be borne in mind when reading the descriptions of the various types. 
Rock Types Occurring in the Roman Region.

\begin{tabular}{|c|c|c|}
\hline SYмвоL. & Name in Quantitative System. & Name in Prevaluing System. \\
\hline 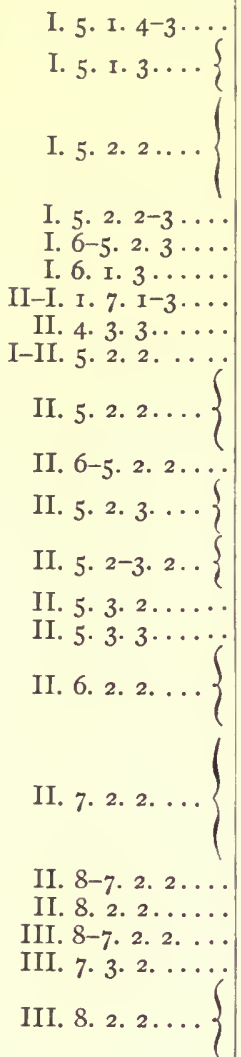 & 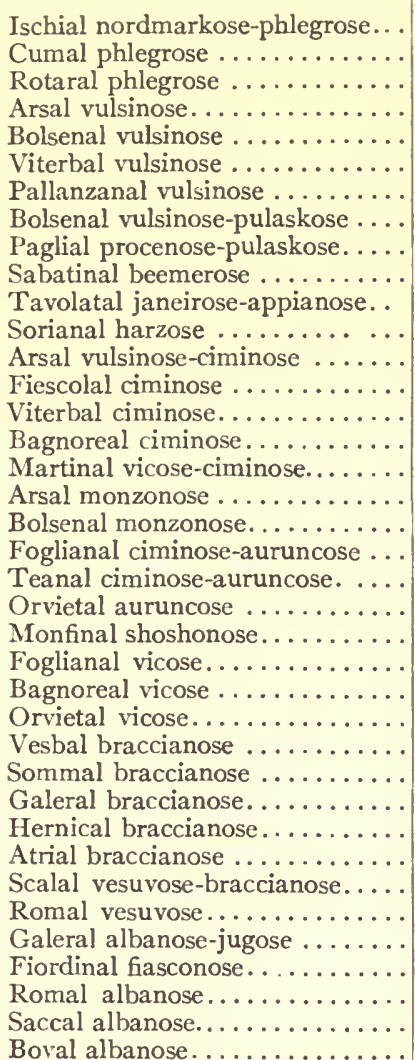 & $\begin{array}{l}\text { Augite-trachyte (Ischia type). } \\
\text { Phonolitic trachyte (Cuma type). } \\
\text { Trachyte obsidian (Rotaro type). } \\
\text { Vulsinite (Arso type). } \\
\text { Vulsinite (Bolsena type). } \\
\text { Leucite-trachyte (Viterbo type). } \\
\text { Leucite-trachyte (Pallanzana type). } \\
\text { Vulsinite (Bolsena type). } \\
\text { Leucite-trachyte (Paglia type). } \\
\text { Leucite-phonolite (Sabatino type). } \\
\text { Leucite-tephrite (Tavolato type). } \\
\text { Biotite-latite (Soriano type). } \\
\text { Vulsinite (Arso type). } \\
\text { Ciminite (Fiescoli type). } \\
\text { Leucite-trachyte (Viterbo type). } \\
\text { Leucite-trachyte (Bagnoreal type). } \\
\text { Leucite-tephrite (San Martino type). } \\
\text { Vulsinite (Arso type). } \\
\text { Vulsinite (Bolsena type). } \\
\text { Leucite-tephrite (Viterbo type). } \\
\text { Leucite-trachvte (Teano type). } \\
\text { Leucite-tephrite (Orvieto type). } \\
\text { Biotite-latite (Monfina type). } \\
\text { Leucite-tephrite (Viterbo type). } \\
\text { Leucite-tephrite (Bagnorea type). } \\
\text { Leucite-tephrite (Orvieto type). } \\
\text { Leucite-tephrite (Vesuvius type). } \\
\text { Leucite-tephrite (Somma type). } \\
\text { Leucitite (Galera type). } \\
\text { Leucitite (Hernici type). } \\
\text { Leucite-tcphrite (Atrio type). } \\
\text { Leucite-tephrite (Scala type). } \\
\text { Leucitite (Rome type). } \\
\text { Leucitite (Galera type). } \\
\text { Leucite-basanite (Fiordine type). } \\
\text { Leucitite (Rone type). } \\
\text { Leucitite (Sacco type). } \\
\text { Leucitite (Bove type) cecilite. }\end{array}$ \\
\hline
\end{tabular}

In the descriptions of the types the order in which they will be taken up is that of their magmatic position, by class, order, rang, and subrang. The divisions below subrang - that is, grads and subgrads-will not be regarded or discussed, as it is thought that there are sufficient new terms used in this paper without adding to them the many complications and more numerous names which the introduction of these minor divisions would involve. It was also thought desirable to determine by actual practice whether the refinement in classification implied by the use of grads and subgrads in the dosalanes and salfemanes is strictly necessary, or whether the general needs of petrographic description and discussion can not be met without their use. In a perfect system, carried out to the last details, they are undoubtedly logical and necessary, but for practical purposés at present it would seem advisable not to discard them, but to avoid the complications that they introduce, and to 
reserve them for the more detailed and special investigations. From examination of the subsequent pages, and when it is considered that the rocks of any one region have certain chemical characters in common, it is fairly clear that grads and subgrads can be dispensed with in great part for general purposes, and that the use of type adjectives will replace them advantageously to a large extent.

In each subrang the general order will be that those types whose modes are most normative will be first described, followed by those which are abnormative, in each case the most coarsely granular, or those with the largest and most abundant phenocrysts, preceding the less porphyritic or aphyric ones. The hyaline types will be the last to be described.

In a number of cases the rock habits will be named-that is, those more general features of mode and texture or both in which rocks may resemble each other without belonging to the same type. The habits named, however, are only a few, and are those which seem to be most common to, or characteristic of, the rocks of the region.

In the statement of the norm one modification from the original has been introduced, the result of a joint discussion of the subject on the part of all the authors of the quantitative system. This has to do with the normative minerals sodalite and noselite. Without going into details here, it was thought advisable to modify these to the extent of splitting them up and stating in the norm the amounts of halite $(\mathrm{NaCl})$ with the symbol $\mathrm{Hl}$, and of thenardite $\left(\mathrm{Na}_{2} \mathrm{SO}_{4}\right)$ with the symbol $T h$, instead of sodalite and noselite. The soda which was previously combined with the sodium chloride and sulphate remains with the rest in calculating the norm, and, if necessary, is distributed between albite and nephelite in the usual way. In some cases a change in the position of the rock as regards the order is thus brought about, but this will happen only when the amounts of chlorine or sulphuric anhydride are large; and, as a matter of fact, it was found that in the present series the systematic position of the rock was not altered, nor the relative amounts of feldspar and lenard changed in the slightest, in any of the few cases in which the sodalite minerals are present. An advantage of this method of procedure is that it minimizes the influence of the small amounts of $\mathrm{Cl}$ and $\mathrm{SO}_{3}$ usually found, which is very great if they bind up in the norm a much greater amount of soda and silica. This matter will be discussed in a forthcoming joint paper, along with other modifications of and additions to the system.

\section{The Formal Descriptions.}

Following the descriptions of the different types, which are couched in the usual petrographical terms, except such as belong to the phraseology of the quantitative system, are what may be called formal descriptions of the types. These aim to give a concise but complete description of the type, both qualitative and quantitative, which may be regarded as standard, and from which one may judge whether another rock belongs to the same type or not, certain narrow departures being 
regarded as allowable. They are based on the descriptions of botany and zoölogy, and follow the plan of these in general, mutatis mutandis.

These have, both in form and in language, been adopted after consultation with my colleagues in the quantitative system, though they may be regarded as possibly not definitive or final, but as an attempt at a more precise and concise statement of the characters of igneous rocks such as is demanded by the new system of classification for the establishing of types. Many of the terms used in these formal descriptions are some which have recently been adopted by ourselves, and which will be published by us elsewhere in a paper setting forth some additions to the quantitative system of classification. Most of these will be self-explanatory.

The general plan on which these formal descriptions are arranged is as follows: The megascopic characters, or those determinable in the field, will be given first; the more general, or those which are discernible at a greater distance from the eye, being stated before the more particular. If phenocrysts are present, they will be named and briefly described megascopically in the order of their abundance. The statement of the specific gravity of the analyzed specimen belongs in this part of the description.

Next follows the description of the characters discernible only in the thin section-the microscopic characters. Here also the more general features of texture, as being the more readily discernible, come first, in the order of characters pertaining to crystallinity, granularity, and fabric. Then follows a succinct statement of the mode, the minerals present being given in the order of abundance, and, if the rock is porphyritic, the phenocrystic minerals preceding those which belong to the groundmass. After this come the descriptions of the several minerals, given in the order of their statement in the norm, though the alferric minerals, which do not belong to the norm, are given in the order, augite, hornblende, biotite, garnet, and precede the femic minerals. The characters of the several minerals are stated in the order of their importance, their relative amount in the rock (by weight, not by volume), their size, crystal development, shape, twinning phenomena, color, inclusions, and arrangement. A detailed statement of the optical and other characters, as extinction angles, pleochroism, zonal variation, etc., will not be attempted, nor are data given as to the order of formation, though these last may well be considered to have a place in the formal description.

It is, of course, understood that the figures expressing relative amounts and sizes, which have been arrived at by study under the microscope, are averages merely, and that other rocks may depart from one or more of them within reasonable limits and still be considered as belonging to the same type.

These formal descriptions are pen pictures of the rocks-skeletons which the imagination of the reader must clothe with reality, but which furnish in concrete form the absolute and relative characters with which other investigators may compare other rocks in the future. They are intended primarily for reference, supplementing and stating the facts of the ordinary descriptions. 
Transitional Types.

In the list of types given above, as well as in the descriptions which follow, there will be noticed a considerable number of types which fall almost on the borders between two or more magmatic divisions, or are "transitional." Their occurrence is of importance as illustrating a feature of the quantitative classification which, as has been said elsewhere, $*$ is not peculiar to it, but is inherent in the character of igneous rocks, so that no "natural" division lines exist, and those which are selected must be arbitrary, in the nature of the case. As has been said, such transitional types are just as important as those which fall at the centers of the various divisions-a fact clearly brought out in the present region, where transitional types are very numerous, and to which belong some of the most abundant and characteristic rocks.

To emphasize this fact of the equality in importance of "central" and "transitional" types, the last have in nearly every case been described separately, even though this involved an increase in the number of types.

In this connection the question naturally arises: How close to the border of a given division must a magma fall to be considered transitional? The answer to this is debatable, and one which has been under consideration by the proposers of the quantitative system for some time. While no definite conclusion has been reached as yet, it would seem that the decision must rest largely upon the petrographer himself in any given case. The need for arbitrary boundaries is not felt here as in the establishment of the definite magmatic divisions, and, furthermore, it is evident that, were the attempt made to establish rigid borders within or outside of which rocks should be said to be or not to be transitional, the difficulty would only be shifted, not eliminated entirely. Thus it might easily happen that the carrying out of the molecular ratios to four instead of three decimal places, or the determination and introduction into the calculation of such minor constituents as zirconia, baryta, or strontia, could change the type from a transitional to a nontransitional one, or vice versa.

The treatment adopted here is rather a tentative than a final one, and in places may not be wholly consistent. As a general rule, a type or a magma has been considered transitional when the ratio in question differs from that of the border line by \pm 0.05 or \pm 0.10 . Thus where the border ratio is $7: 1$, the magma is regarded as transitional if the ratio falls between 6.90 and 7.10. If the ratio of the border is $5: 3=1.666+$, the magma is regarded as transitional if it falls between 1.60 and I.70, a difference here of only about \pm 0.05 , as the border ratio is less than in the other case. But these are only in the nature of general and tentative suggestions, and this seems to be one of the features of the quantitative classification which it were best to leave somewhat indefinite, just as are the limits of identity or similarity in mode and texture which may define a type, and which are briefly discussed on another page.

* Cross, Iddings, Pirsson, and Washington, op. cit., pp. I21, 166, 231; Iddings, Prof. Paper U. S. Geol. Surv. No. 18, 1903, p. 69; Pirsson, Bull. U. S. Geol. Surv. No. 237, 1905, p. 120. 


\section{Determination of Mrnor Constituents.}

The remarks above lead to the consideration of another matter of some importance which is clearly brought out in the following pages, namely, the importance in the quantitative system of determining the chemical constituents which are usually regarded as minor, or at least some of them. It will be observed in a number of cases that the classificatory position of a rock is changed by the determination of and introduction into the calculation of some constituent, as $\mathrm{TiO}_{2}$ or $\mathrm{P}_{2} \mathrm{O}_{5}$, which is present only in very small amount, sometimes less than one-half of I per cent. Thus the arsal vulsinose-ciminose [vulsinite] of Vetralla was formerly placed in vulsinose, but the recent determination of $0.6 \mathrm{I} \mathrm{TiO}_{2}$ and $0.17 \mathrm{P}_{2} \mathrm{O}_{5}$ shows that it is properly in ciminose; similarly, the determination of $0.77 \mathrm{P}_{2} \mathrm{O}_{5}$ has shifted the "leucite-tephrite" of $\mathrm{La}$ Scala from vesuvose into braccianose. Such cases are to be expected, and while they may be considered by some to be a practical defect in the quantitative system in demanding what may seem to be ultra-refinements in the chemical analysis, they can not justly be regarded in this light. This has been briefly discussed elsewhere,* and it was pointed out that it is "not an objection, but really a very strong point in favor of the new system. For it postulates as fundamental to the classification the absolute necessity for only the best class of analytical work." And it may be said in addition, though it can not be held as an excuse for, or as justifying, incomplete analyses, that changes thus brought about by the determination of these minor constituents will usually happen only when the rock is transitional as to magmatic position.

In the present case, however, some of the rocks involved are of such a character that the determination of small amounts of $\mathrm{TiO}_{2}, \mathrm{P}_{2} \mathrm{O}_{5}$, etc., or slight inaccuracies in the determination of the main constituents, as silica or the alkalis, will bring about very serious changes in the magmatic position. These rocks are those which belong to the more lenic orders of dosalane, braccianose and vesuvose, and to the salfemanes. In the present region these rocks are leucitic without exception; that is, are dopotassic and with a deficiency of silica. On account of the silica relations of orthoclase and leucite with 64.75 and 55.05 per cent of silica respectively, a very slight difference in the amount of silica or the alkalis, or in other components, may bring about very decided changes in the norm, owing to the readjustments of potash between the polysilicate orthoclase, $\mathrm{KAISi}_{3} \mathrm{O}_{8}$, and the metasilicate molecule, $\mathrm{KAlSi}_{2} \mathrm{O}_{6}$.

In other words, the limits of the dopotassic subrangs of these lenic orders are very narrow. This is very clearly shown by Iddings $\dagger$ in his diagram of the limits of orders and rangs for theoretically pure potash-salic rocks. In this the uniformly smaller area of the potassic subrangs, as compared with the purely sodic ones, and especially the extremely small dimensions attained by the potassic divisions as the silica decreases and the amount of the lenad leucite rises, are very clearly brought

* Washington, Prof. Paper U. S. Geol. Surv. No. 14, 1903, p. 44.

† Iddings, Prof. Paper U. S. Geol. Surv. No. 18, 1903, p. 72 and Plate II. 
out, and will repay some study. This matter will be discussed later in connection with the formation of leucite.

\section{5. 1. 4-3. Ischial Nordmarkose-Phlegrose [Augite-Trachyte, Ischia Type].}

Megascopic characters.-Rocks of this type are light gray, rough in feel, and highly porphyritic. The most abundant phenocrysts are of feldspar, which constitute about 30 per cent of the rock. These are tabular or stout prismatic, from Io to $20 \mathrm{~mm}$. long, colorless, and with a highly vitreous luster. From the absence of twinning striations they would be considered to be orthoclase. Small prismatic phenocrysts of black augitè and grains of magnetite are very rare, not making up more than I or 2 per cent of the rock. The groundmass is very light gray and phanerocrystalline, but very fine-grained. It is obviously composed almost exclusively of salic minerals, presumably feldspars.

Microscopic characters. - The thin sections show the following minerals: Alkali feldspar very abundant, with less augite and magnetite, and accessory lavenite and sodalite. The texture is typically holocrystalline, and with a characteristic trachytic fabric.

The feldspar phenocrysts are of soda-orthoclase in thick subhedral tables, tabular parallel to $b$ (oro), or occasionally stoutly prismatic parallel to the $a$ axis. They are not uncommonly fragmentary, having been broken during the flow. Although their sodic character is certain from chemical analysis, the microscopic appearances so characteristic of soda-orthoclase are usually absent. They show, for the most part, a clear, even gray between crossed nicols, without the lamellæ of microcline, microperthitic intergrowths of orthoclase and albite, or the common moire appearance. The rare augite phenocrysts are subhedral, in stout prismoids, and of a very pale-gray color, or with only an extremely faint tinge of green. Inclusions are very rare both in these and in the feldspar phenocrysts.

The groundmass has the typical trachytic fabric, and usually with marked evidences of flow. It is composed in very great part of small prismoids of alkali feldspar, elongated parallel to the axis $a$. Small prismoids of colorless augite and grains of magnetite are present, but only in negligible amounts. In some specimens lavenite occurs as a rare accessory, in small, yellow, pleochroic prismoids, often arranged in divergent clusters; but this mineral can not be regarded as characteristic of the type. The same is true of sodalite, which is sometimes present in very small amount in the groundmass as colorless, rounded anhedra, as well as in crevices of the rock. No glass could be detected in most of the specimens, though it may be present to a very slight extent.

Chemical composition.-An analysis of this type was published some years ago, and is here repeated in more complete form. An older analysis by Fuchs is also given for comparison.

The analysis is noteworthy because it shows that a typical "trachyte," which is regarded as composed essentially of orthoclase, may carry as much soda as potash 
in percentages, and that molecularly the former may surpass the latter. The exact classificatory position of this type is clear from the ratios. As regards class, order, and rang, it falls well within the borders of persalane, canadare, and nordmarkase; but the ratio of the alkalis shows that the rock is transitional between the sodipotassic subrang phlegrose, in which it actually falls, and the dosodic subrang nordmarkose. This type must therefore be called a nordmarkose-phlegrose.

Chemical Composition of Ischial Nordmarkose-phlegrose [Augite-trachyte].

\begin{tabular}{|c|c|c|c|c|c|c|c|}
\hline & &. & II. & & I & & II. \\
\hline 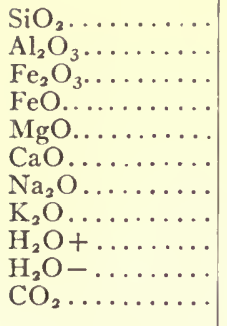 & $\begin{array}{r}61.88 \\
18.06 \\
2.19 \\
1.38 \\
0.61 \\
1.15 \\
6.89 \\
6.72 \\
0.37 \\
\text { none }\end{array}$ & $\begin{array}{l}\text { I.03I } \\
.178 \\
.014 \\
.019 \\
.015 \\
.021 \\
.111 \\
.071\end{array}$ & $\begin{array}{r}61.49 \\
20.02 \\
3 \cdot I 1 \\
2.72 \\
0.52 \\
1.88 \\
3.39 \\
7.13 \\
0.46 \\
\ldots \ldots\end{array}$ & 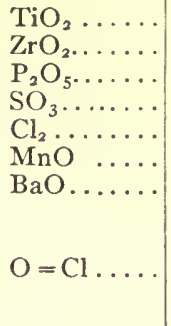 & $\begin{array}{r}0.69 \\
0.08 \\
0.07 \\
0.05 \\
0.30 \\
\text { n.d. } \\
0.08 \\
100.52 \\
0.07 \\
100.45\end{array}$ & $\begin{array}{r}0.009 \\
.001 \\
.004\end{array}$ & $\begin{array}{c}\ldots \\
\cdots \\
0.02 \\
\cdots \\
\cdots \\
\cdots \\
0.01 \\
100.75\end{array}$ \\
\hline
\end{tabular}

I. Ischial phlegrose (augite-trachyte). Marecocco, Ischia. Washington, analyst. $A m$. Jour. Sci., VIII, I899, p. 289 .

II. Ischial phlegrose (augite-trachyte). Marecocco, Ischia. Fuchs, analyst. Tsch. Min. Mitth., 1872, p. 229 .

Norm of $I$.

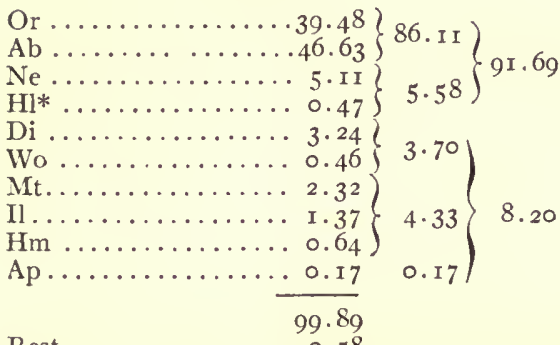

Rest................ $\frac{0.58}{100.47}$ Ratios of $I$.

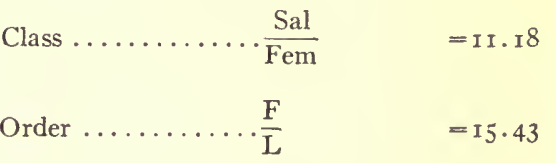

$* \mathrm{Hl}=$ halite $(\mathrm{NaCl})$; cf. p. 15 .

The figures for some of the constituents in the analysis of Fuchs (II) closely resemble mine. That his determinations of the alkalis are not correct is indicated by the calculation of the norm of his analysis, which proves that these are not present in sufficient amount to satisfy the silica and alumina.

Mode.-The mode of the specimen analyzed was determined by Rosiwal's method, and is given in the table below. It must be observed, however, that no sodalite could be detected in the thin sections of the rock analyzed, and a test on the section by Lemberg's method with dilute nitric acid and silver nitrate solution gave a negative result. It is possible that it was present in crevices of the piece analyzed, or else possibly existent as a glass, in which form it would be very difficult to detect 
among the fine feldspar laths of the groundmass. As the figure for chlorine is concordant with that shown in other analyses of closely related rocks from the same district, it is justifiable to assume that the amount is correct. Furthermore, a study of the norm shows that a lenad must be present in the mode, since there is not enough silica to form albite with all the soda. The amount of nephelite shown in the norm is just enough to form sodalite with the normative halite ( 3.88 per cent), leaving only r.70 of nephelite free. Consequently, in the calculated mode given in the first column, obtained by readjustment from the norm, the sodalite is stated to be present as such, while in the measured mode it is bracketed with the orthoclase. In any case the amount of this mineral, as well as of lavenite, is quite negligible; so the mode is a normative one, and the rock may be described as normative trachiphyro-phlegrose.

\begin{tabular}{|c|c|c|c|c|c|}
\hline & Calculated. & & Measur & ED. & \\
\hline 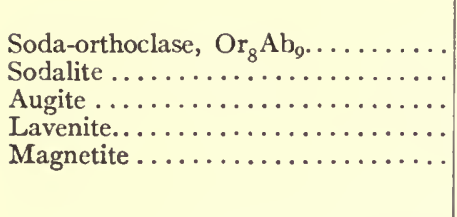 & 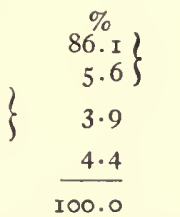 & $\begin{array}{r}\text { Vol. \% } \\
94.16 \\
2.25 \\
0.68 \\
2.91 \\
100.00\end{array}$ & $\begin{array}{l}\text { Sp.gr. } \\
\times 2.6= \\
\times 3.3= \\
\times 3.5= \\
\times 5.2=\end{array}$ & $\begin{array}{r}244.82 \\
7.43 \\
2.45 \\
\quad 15.13 \\
269.83\end{array}$ & $\begin{array}{r}\text { Wt. \% } \\
90.73 \\
2.75 \\
0.9 \mathrm{I} \\
5.6 \mathrm{I} \\
100.00\end{array}$ \\
\hline
\end{tabular}

Occurrence.--Ischial phlegrose is especially abundant on the island of Ischia, where it was found, among other localities, at Marecocco and Zale, probably the site of the eruption of about $470 \mathrm{~B} . \mathrm{C}^{\text {. } *}$ at Monte Rotaro, probably due to an eruption between 400 and 352 B. C.; at Carbone and near Scanella. The flow at Monte Olibano in the Phlegrean Fields may also be referred to this type, though somewhat transitional toward the cumal type, to be described presently. Outside of the Campanian District rocks of this type were met with by me only at the Molino di Casa Fredda, in the Auruncan District.

Name.-The name of the subrang is, of course, derived from the Phlegrean Fields, where this magma is predominant, and where specially well-known types of it occur. The type adjective is derived from the island of Ischia, on which the type is abundant.

In the prevailing systems of classification this rock is regarded as a typical augite-trachyte, of the Ponza typus of Rosenbusch, though with affinities toward his phonolitic trachyte, through the presence of sodalite and lavenite.

ISCHIAL NORDMARKOSE-PHLEGROSE. I. 5. 1. 4-3.

Megascopic characters.-Very light gray, compact, highly porphyritic. Feldspar phenocrysts abundant, ro to $20 \mathrm{~mm}$. long, tabular or stout prismatic, clear and colorless. Augite and magnetite phenocrysts very few, 0.5 to I mm. long; augite stout prismatic, magnetite equant. Groundmass: very light gray, fine grained, phanerocrystalline.

Microscopic characters.-Holocrystalline, megaporphyritic, dopatic, magnophyric. Phenocrysts: about 33 per cent, soda-orthoclase, augite, magnetite. Groundmass: about 67 per

* C. W. C. Fuchs, 18, p. 237 . 
cent, trachytic fabric, soda-orthoclase, augite, lavenite, sodalite, magnetite. A very little glass base may be present.

Soda-orthoclase.-Phenocrysts: about 30 per cent, to to $20 \mathrm{~mm}$., euhedral to subhedral, often fragmentary, mostly tabular parallel to $b$ (оIO) or stout prismatic parallel to axis $a$, microperthite and microcline structures generally wanting, Carlsbad twinning common, inclusions rare. Groundmass: about 60 per cent, 0.05 to $0.20 \mathrm{~mm}$., subhedral, prismatic parallel to axis $a$, arrangement parallel or subparallel.

A ugite.-Phenocrysts: about I per cent, 0.2 to $1.0 \mathrm{~mm}$., subhedral to anhedral, prismoidal, very pale gray or slightly yellowish green, non-pleochroic, no inclusions. Groundmass: about 2 per cent, 0.05 to $0.20 \mathrm{~mm}$., anhedral, prismatic, colorless or very pale gray.

Magnetite.-Phenocrysts: about I per cent, 0.2 to $0.4 \mathrm{~mm}$., anhedral, equant. Groundmass: about 2 per cent, 0.01 to $0.05 \mathrm{~mm}$., subhedral, equant.

Sodalite.-A small amount, about 3 per cent, may be present, either as equant anhedra in the groundmass or in crevices of the rock, but is not essential to the type.

Lavenite.-Groundmass: about I per cent, 0.1 to $0.2 \mathrm{~mm}$, subhedral prismatic or anhedral equant, pale to deep yellow, nonpleochroic, not essential to type.

Chemical composition as in analysis I, p. 20.

Type specimen from Marecocco, Ischia.

\section{5. 1. 3. Cumal Phlegrose [Phonolitic Trachyte, Cuma Type].}

Megascopic characters.-This type is closely similar to that just described, as far as the mode is concerned, but differs texturally in the much smaller number and size of the phenocrysts. The rocks are very light gray, in some cases slightly greenish, and with a somewhat greasy luster. There may be schlieric patches of darker material, which does not differ essentially from the lighter, except in color, but these are not regarded as characteristic of the type.

The phenocrysts constitute only about Io per cent of the mass. The majority of them are of alkali-feldspar, in small, subhedral stout prisms or thick tables. Very small phenocrysts of sodalite are also seen, but in much less amount than those of feldspar, and crystals of this mineral may be found in crevices. Their color is sometimes blue, but they are more often colorless. Still less abundant are the small prismatic phenocrysts of augite.

In some specimens, as those of this type from the tuffs of the Vico Volcano, there are present rare, rounded white phenocrysts of leucite, about $5 \mathrm{~mm}$. in diameter. Their number is very few, not over two or three being visible in a goodsized hand specimen. The light-gray groundmass is aphanitic, sometimes with a dull, sometimes with a slightly greasy, luster.

Microscopic characters. - In thin section these rocks are typically holocrystalline, though very small amounts of glass may be present. The fabric is a trachytic one, though in this type most of the specimens do not show such a well-marked fluidal arrangement of the feldspar laths as in the preceding one. The rare phenocrysts of soda-orthoclase offer nothing specially noteworthy, resembling those of the ischial type, except in their smaller size. The phenocrysts of augite are either euhedral or subhedral, are decidedly olive-green in color, markedly pleochroic, and with the axis of greatest elasticity $a$ at an angle of $30^{\circ}$ with the vertical axis. They are therefore of ægirite-augite. The sodalites are either colorless, when they are 
distinguishable only with difficulty, as at the Phlegrean Fields, or blue, with the characteristic dusty inclusions arranged in lines, as in the blocks from Monte Vico.

The groundmass is composed in very large part of a soda-orthoclase in very small prismoids, usually with a subparallel arrangement. There are also a few minute anhedra of very pale greenish or grayish augite, occasionally small anhedra of sodalite, and usually a little nephelite interstitial between the feldspar laths, and often difficult to detect. Magnetite is usually present in very small amount, but not invariably, while lavenite is sometimes found. In some specimens there are small euhedral individuals of titanite, but this is a purely accessory constituent. Glass may be present in some cases, but its amount is always small, and it is difficult to detect on account of the character of the groundmass.

Chemical composition.-Analyses of three occurrences of cumal phlegrose were published several years ago, and are given below with the addition of determinations of some of the minor constituents. Those from the Phlegrean Fields (Monte di Cuma and Monte Nuovo) scarcely differ from each other, but the third, from Monte Vico, shows a very considerably greater amount of potash relatively to the soda, though the ratios of the alkalis in all three are so near unity as to cause all to fall in the same sodipotassic subrang. It is also seen that in the Monte Vico rock sulphur trioxide partially replaces the chlorine of the other two, though the amounts are so small in all cases as to be negligible for purposes of classification. The analysis by vom Rath (IV) is very probably of the same type as III, but it is almost certain that through some error the alkalis have been interchanged.

Chemical Composition of Cumal Phlegrose [Phonolitic Trachyte.]

\begin{tabular}{|c|c|c|c|c|c|c|c|}
\hline & \multicolumn{2}{|c|}{ I. } & \multicolumn{2}{|c|}{ II. } & \multicolumn{2}{|c|}{ III. } & IV. \\
\hline \multirow{15}{*}{ 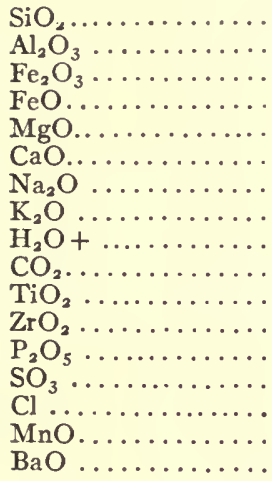 } & $59 \cdot 79$ & 0.997 & 60.33 & I. .006 & $59 \cdot 24$ & 0.987 & 60.18 \\
\hline & 19.05 & .187 & I 8.27 & . I 79 & 18.63 & . 183 & 18.70 \\
\hline & 2.05 & .019 & 2.84 & .018 & $3.3^{\circ}$ & .021 & ... \\
\hline & I. 08 & .015 & I. 29 & .018 & I. 20 & .017 & $3 \cdot 44$ \\
\hline & $0.3^{6}$ & .009 & $0.3^{8}$ & .010 & 0.12 & .003 & $0.3^{2}$ \\
\hline & I. I9 & $.02 \mathrm{I}$ & I. I 5 & .021 & 2.06 & .037 & 2.80 \\
\hline & 6.79 & . IIO & 7.15 & . I I5 & 4.87 & .079 & 9.67 \\
\hline & $7 \cdot 10$ & .076 & $7 \cdot 30$ & .078 & 9.14 & .097 & 4.18 \\
\hline & $\begin{array}{l}0.24 \\
\text { none }\end{array}$ & & $\begin{array}{l}0.5^{6} \\
\text { none }\end{array}$ & & $\begin{array}{l}0.86 \\
\text { none }\end{array}$ & & 0.33 \\
\hline & $0.5^{6}$ & .007 & 0.43 & .005 & 0.56 & .007 & $\ldots$ \\
\hline & $\ldots$ & & $\ldots$ & & 0.10 &.$\infty \mathrm{I}$ & $\cdots$ \\
\hline & 0.10 & .001 & 0.04 & & 0. 15 & .001 & $\cdots$ \\
\hline & none & & none & & 0.17 &.$\infty 2$ & 0.19 \\
\hline & 0.53 & .014 & 0.43 & .012 & 0.08 & .002 & 0.14 \\
\hline & $\begin{array}{l}\text { n.d. } \\
\ldots . .\end{array}$ & & $\begin{array}{l}\text { n.d. } \\
\ldots . .\end{array}$ & & $\begin{array}{l}\text { n.d. } \\
0.06\end{array}$ & & $\cdots$ \\
\hline \multirow{3}{*}{$\mathrm{O}=\mathrm{Cl} \ldots \ldots \ldots \ldots$} & $99 \cdot 74$ & & 100.17 & & 100.54 & & 99.95 \\
\hline & 0.12 & & 0.10 & & 0.02 & & \\
\hline & 99.62 & & 10007 & & $100 \cdot 5^{2}$ & & \\
\hline Sp. gr........... & & & & & \multicolumn{2}{|l|}{2.509} & \\
\hline
\end{tabular}


Notes Explaining Headings or Preceding Table.

I. Cumal nordmarkose-phlegrose [phonolitic trachyte]. Monte di Cuma, Phlegrean Fields. Washington, analyst. Cf. Am. Jour. Sci., VIII, r899, 287.

II. Cumal nordmarkose-phlegrose [phonolitic trachyte]. Monte Nuovo, Phlegrean Fields. Washington, analyst. Cf.'Am. Jour Sci., VIII, I899, 287.

III. Cumal phlegrose [phonolitic trachyte]. Block in tuff, Via Aurelia, $4 \mathrm{~km}$. SW. of Viterbo, Ciminian District. Washington, analyst. Cf. Jour. Geol., IV, I896, 849.

IV. Cumal phlegrose [phonolitic trachyte]. Monte Cimino, near Viterbo. vom Rath, analyst. Zeits. d. d. geol. Ges., XVIII, I866, p. 58r, alkalis interchanged?

Norms.

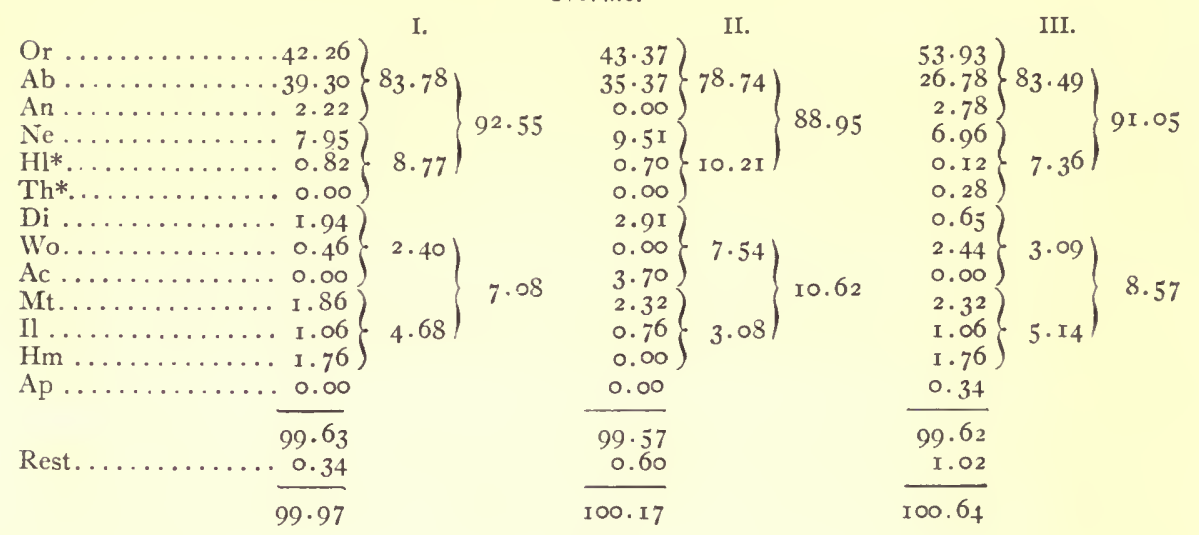

Ratios.

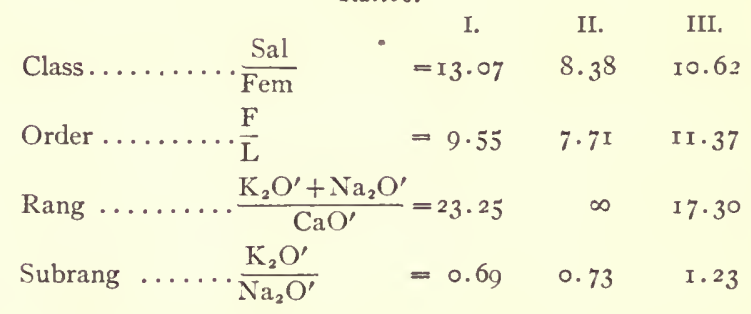

*For $\mathrm{Hl}$ and $\mathrm{Th}$ see $\mathrm{p} . \mathrm{I5}$.

From these norms and ratios it is seen that the rocks from the Phlegrean Fields approach the border of the dosodic subrang nordmarkose, like the ischial type, and they might be considered as transitional and the subrang be called nordmarkose-phlegrose. On the other hand, the Vico rock is close to the center of the sodipotassic subrang, and the potash indeed slightly surpasses the soda. In other respects they are all well within the limits of class, order, and rang.

Modes.-The mode of the Cuma specimen, both as calculated from the norm and as measured by Rosiwal's method, is given below. In the former the amount of sodalite was calculated on the basis of the figures for chlorine reported, and is seen to be very close to the measured value. As the composition of the ægiriteaugite was unknown, and the whole of the normative hematite would yield far too much ægirite, an amount of $\mathrm{Na}_{2} \mathrm{O}(.004)$ equivalent to that of $\mathrm{CaO}$ in the wol- 
lastonite was taken as a basis, which would give a composition approximately like that of most ægirite-augites, the rest of the hematite being placed with the ores. The $\mathrm{CaO}$ of the wollastonite takes up, then, just the amount of $\mathrm{Al}_{2} \mathrm{O}_{3}$ set free from nephelite by the transfer of $\mathrm{Na}_{2} \mathrm{O}$ to acmite, to form anorthite (3.3 per cent) which, with that calculated normatively, must exist in the feldspar. A small amount of nephelite is necessarily present, but this would easily escape observation, owing to

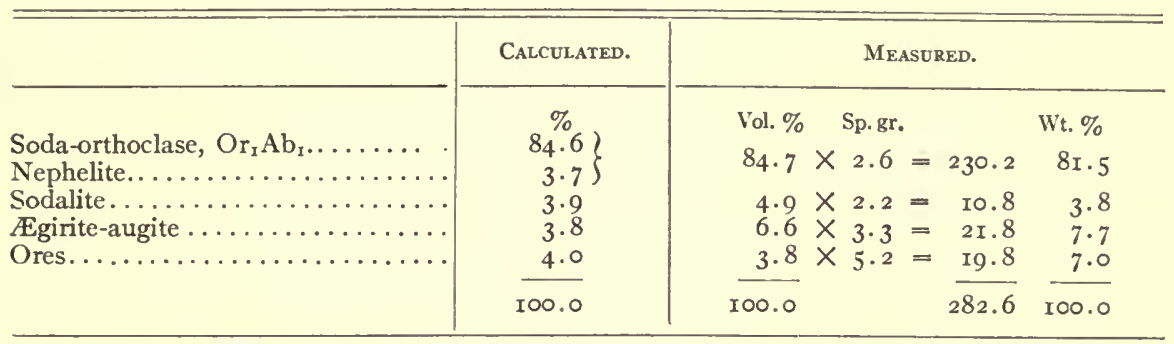

the fabric of the groundmass. Allowing for these readjustments, the average composition of the alkali-feldspar would be $\mathrm{Or}_{76} \mathrm{Ab}_{75}$; that is, almost exactly $\mathrm{Or}_{\mathrm{I}} \mathrm{Ab}_{\mathrm{I}}$.

In the measured mode the nephelite has been measured with the feldspar, and the amount of these is seen to be rather less than the calculated amount. On the other hand, the measured amounts of pyroxene and ores, the colored minerals, are rather higher than those calculated by the same figure, these for sodalite being almost identical. This discrepancy, though not serious, may be attributed to the overlapping of the small mineral grains, and a consequent greater apparent amount of the colored ones, a point we shall have to notice later.

The mode of the blocks from Monte Vico was also calculated and measured with the following results. The process of calculation was very similar to the pre-

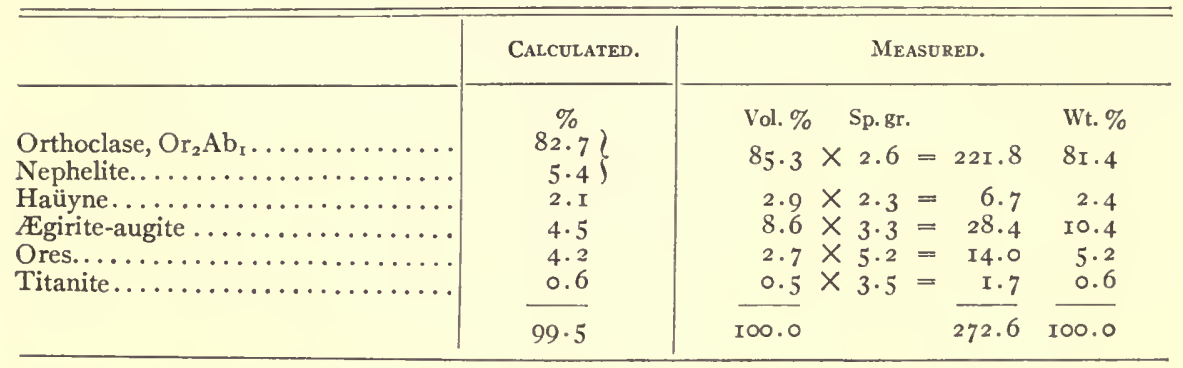

ceding. The measured amount of titanite was assumed to be correct, and the FeO thus set free from normative ilmenite placed in a diopside molecule, the extra lime being taken from normative wollastonite. A small amount of ægirite was arbitrarily calculated, as in the last case, and an amount of anorthite corresponding to this calculated, the total amount of this being 3.6, which goes into the feldspar. 
The wollastonite which was left over was placed in the ægirite-augite molecule though it is a trifle high. There not being enough $\mathrm{SiO}_{2}$ left to form albite from all the $\mathrm{Na}_{2} \mathrm{O}$ present, nephelite was calculated by the same set of equations used to calculate the norm, exactly as was done in the preceding mode. The average alkalifeldspar, then, will be $\mathrm{Or}_{97} \mathrm{Ab}_{48}$, or almost exactly $\mathrm{Or}_{2} \mathrm{Ab}_{1}$.

Comparison with the measured mode shows the same relations as in the case of the Cuma rock, though here it is considerably greater, and is also to be attributed to overlapping. The calculated and measured amounts of haüyne are very concordant, which in both cases is to be attributed to the rather fair size of the crystals, equaling or excelling the thickness of the section, and their equant shape and consequent small liability to overlapping.

The mode of the Monte Nuovo rock was not calculated or measured, as it was deemed to be superfluous. It may be assumed to correspond closely with that of the Cuma phlegrose.

Taking all the above facts into consideration, we may conclude that the mode of cumal phlegrose is best represented by the two calculated modes given above, rather than by the measured ones. The variations from the norm are inconsiderable, and these rocks can readily be classified as far as rang by a microscopic examination alone, and, if the highly sodic character of the alkali-feldspar were known, as far as subrang. They would therefore be described as normative trachiphyrophlegrose.

Occurrence.-Cumal phlegrose is most typically and abundantly represented in the Phlegrean Fields, where it occurs at Monte di Cuma, Monte di Procida, and as blocks at Monte Nuovo, as well as other localities. The well-known "piperno" of Pianura might be considered to be of this type, though the entire absence of phenocrysts and the peculiar eutaxitic texture shown in the "flames" of darker material would justify the establishment of a separate type for this, which might be called the pianural. The cumal type is also frequent on Ischia, as at Monte Tabor, Monte Rotaro, Punto di Castiglione, Scanella, Panza, and elsewhere. Outside of the Campanian District these rocks are comparatively rare. They are met with in the Auruncan District, where they form flows east of Casi near Teano, below Orchi, and possibly elsewhere, and in the Ciminian District, where the type occurs as blocks in yellow tuffs around Monte Vico and possibly as a few flows.

Name.-The type name is derived from the locality of Cuma in the Phlegrean Fields, the earliest Greek settlement of the neighborhood and a prominent locality for the type.

In the prevailing classifications these rocks would be properly called trachyte, and would, for the most part, fall under the head of phonolitic trachytes of Rosenbusch, though he classes some of the occurrences as acmite-trachyte, and others as augite-trachyte. The rocks of this type from Monte Vico were formerly called phonolite by me, but this name lay undue stress on the presence of nephelite and haüne, the amounts of which are in reality very small. 
CUMAL PHLEGrose. I. 5. 1.3.

Megascopic characters.-Light gray, compact, slightly porphyritic. Feldspar phenocrysts rare, I to $5 \mathrm{~mm}$., stout prismatic or tabular, clear and colorless. Sodalite or haüyne phenocrysts rarer, not always visible, about I mm., colorless or blue, equant. Augite phenocrysts very rare, about I mm., prismatic, black. Groundmass: aphanitic, light gray, usually dull, but sometimes with slightly greasy or silky luster, often mottled with darker schlieren.

Microscopic characters.-Holocrystalline, megaporphyritic, perpatic, mediophyric. Phenocrysts: ro per cent or less, soda-orthoclase, sodalite or haüyne, ægirite-augite. Groundmass: $9 \circ$ per cent or more, soda-orthoclase, sodalite or haüyne, nephelite, ægirite-augite, magnetite, titanite, occasionally a little glass.

Soda-orthoclase, $\mathrm{Or}_{2} \mathrm{Ab}_{1}$ to $\mathrm{Or}_{1} \mathrm{Ab}_{1}$. - Phenocrysts: about 5 per cent, I to $5 \mathrm{~mm}$., euheral to subhedral, tabular parallel to $b$ (oro) or stout prismatic, microperthite and microcline structures wanting, Carlsbad twinning common, inclusions rare. Groundmass: about $9 \circ$ per cent, 0.05 to $0.20 \mathrm{~mm}$., subhedral prismatic, arrangement parallel or subparallel.

Sodalite or haüyne.-Phenocrysts: about 3 per cent, 0.5 to $2.0 \mathrm{~mm}$., subhedral, equant, colorless or blue, inclusions sometimes common, dusty, in fine lines. Groundmass: about 2 per cent, same as phenocrysts but much smaller.

Egirite-augite.-Phenocrysts: about 2 per cent, 0.5 to $2.0 \mathrm{~mm}$., subhedral, prismatic, pale olive-green, pleochroic. Groundmass: about 2 per cent, 0.05 to 0 . Io $\mathrm{mm}$., subhedral, prismatic, pale green or gray.

Magnetite.-Groundmass: about 3 per cent, 0.05 to $0.5 \mathrm{~mm}$., anhedral, equant.

Titanite.-Groundmass: about 0.5 per cent, $0.5 \mathrm{~mm}$., euhedral.

Nephelite.-Groundmass: about 5 per cent, formless areas, interstitial between the feldspar prisms, colorless.

Chemical composition as in analyses I, II, and III, p. 23.

Type specimens from Monte di Cuma and Monte Nuovo, Phlegrean Fields, and Monte Vico, Ciminian District.

\section{5. 1. 3. Rotaral Phlegrose [Trachyte Obsidian, Rotaro Type].}

Megascopic characters.-Megascopically these rocks show rather numerous (about I5 per cent) white phenocrysts of alkali-feldspar, in stout prisms, from I to $5 \mathrm{~mm}$. long, and which stand out prominently against the dark groundmass. The very dark gray or black groundmass is either obviously hyaline to the naked eye or else aphanitic and with a rough fracture; but even in this last case examination with the lens and the natural surfaces of the lava blocks shows that it is highly vitreous.

Microscopic characters. - In thin section the feldspar phenocrysts are clearly of a sodic orthoclase, usually with Carlsbad twinning, and the few small phenocrysts of augite show a very pale gray or yellowish green and those of biotite a brown color. The groundmass varies considerably, enough so as to permit the establishing of several distinct types, were this desirable. In some cases, as in specimens from the Monte di Procida, as well as some Ischian localities, it is an almost pure glass of a light-brown color and quite free from microphenocrysts or microlites. In others, as in the Monte Rotaro rocks most typically, it is quite thickly strewn with small, prismatic microphenocrysts of sodic feldspar, which are sometimes much branched. It was noticed that the rocks in which the glass cement is most free from these small crystals are very friable and break into small pieces under the hammer, not showing the solidity and coherence of such well-known obsidians as those of Lipari, Iceland, or the Yellowstone Park. 
Chemical composition and mode.-Only one analysis was made of this type, and this of a rock of somewhat exceptional textural character. While, therefore, in the absence of analysis, and in view of the abundance of the glass base and the consequent indeterminability of the mode, the magmatic position can not be definitely established for all the specimens, there is little reason to doubt that all those obtained in the Campanian District belong to the subrang phlegrose, where the great majority of the holocrystalline, and hence determinable, rocks fall. There is all the more reason for this belief in the fact that no soda-lime feldspars were observed either among the phenocrysts or the microlites. In the rocks of the Phlegrean Fields which fall in vulsinose, and which carry modal labradorite, this mineral is invariably present as large phenocrysts. It is therefore justifiable to think that, were these rocks in question domalkalic, they would show phenocrysts of labradorite. No definite proof can be given to show that they are sodipotassic, except that of an analysis, and it is possible that some of them are dosodic, and hence in nordmarkose. But when the general character of the district is considered, this does not seem very probable.

Chemical Composition of Rotaral Phlegrose [Trachyte Obsidian].

\begin{tabular}{|c|c|c|c|c|c|c|}
\hline & & I. & II. & & I. & II. \\
\hline \multirow{8}{*}{ 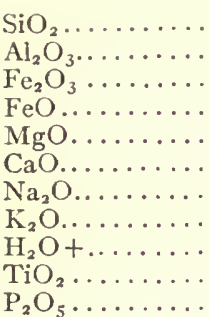 } & 61.62 & 1.027 & 60.77 & \multirow{4}{*}{$\begin{array}{l}\mathrm{Cl} \ldots \ldots \ldots \\
\mathrm{MnO} . . .\end{array}$} & \multirow[t]{5}{*}{0.004} & $\ldots$ \\
\hline & $\begin{array}{r}\text { I8. II } \\
2.36\end{array}$ & $\begin{array}{r}0.177 \\
.015\end{array}$ & $\begin{array}{r}19.83 \\
4.14\end{array}$ & & & trace \\
\hline & I. 28 & .018 & 2.43 & & & 100.55 \\
\hline & $0.5^{6}$ & ..014 & 0.34 & & & \\
\hline & I. 44 & .026 & 1.63 & \multirow[t]{2}{*}{$\mathrm{O}=\mathrm{Cl} \ldots}$. & & \\
\hline & $\begin{array}{l}5.77 \\
7.60\end{array}$ & $\begin{array}{l}.093 \\
.081\end{array}$ & $\begin{array}{l}4.90 \\
6.27\end{array}$ & & 100.64 & \\
\hline & $0.7^{8}$ & & $0.4^{6}$ & \multirow{2}{*}{ Sp.gr...... } & & ? \\
\hline & $\begin{array}{l}0.07 \\
0.13\end{array}$ & .001 & trace & & & 2.44 \\
\hline
\end{tabular}

I. Rotaral phlegrose [trachyte-obsidian]. Monte Rotaro, Ischia. Washington, analyst. Cf* Am. Jour. Sci., VIII, 1899, 289.

II. Rotaral phlegrose [trachyte-obsidian]. Monte Rotaro, Ischia. Fuchs, analyst. Tsch. min. Mitth., I872. p. 232.

Norm of $I$.

Or.............................. 45 )

Ab.................................

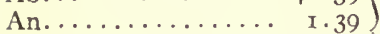

Ne.....................................

HIl......................................

Di......................................

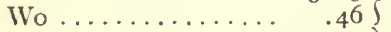

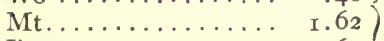

$\left.\begin{array}{lll}\mathrm{Il} \ldots \ldots \ldots \ldots \ldots \ldots & \text { I. } 67 \\ \mathrm{H} m \ldots \ldots \ldots & \text { I. } 28\end{array}\right\}$

Ap............ 0.24

99.85

Rest........... 0. $0.7^{8}$
8.82 $91 \cdot 45$

$3 \cdot 49$

$4 \cdot 57$

0.34

8.40

Ratios of $I$.

Class............ $\frac{\text { Sal }}{\mathrm{Fem}} \quad=\mathrm{I} 0.89$

Order.......... $\frac{F}{L} \quad=24 \cdot$ I9

Subrang............ $\frac{\mathrm{K}_{2} \mathrm{O}^{\prime}}{\mathrm{Na}_{2} \mathrm{O}^{\prime}} \quad=0.87$ 
The very close resemblance between this analysis and the preceding ones is evident, though the norm shows that this rock is nearer all the center points of phlegrose than any of the others. This is especially true of the ratio of soda to potash, which is very close to unity, instead of approaching the dosodic border as in the other phlegroses of the district.

As the mode is indeterminate through the presence of abundant glass, it is not possible to discuss the relations of norm and mode. It may be observed, however, that the greater part of the normative augite and magnetite molecules, with the sodalite, have not crystallized out, but exist in the glass base. Were the rock holocrystalline, its mode would have been undoubtedly almost identical with that of the Cuma phlegrose, and the average feldspars would have had the composition $\mathrm{Or}_{\mathrm{y}} \mathrm{Ab}_{\mathrm{y}}$.

Occurrence.-In the Roman Region the rotaral type is found only in the Campanian District, and even here is by no means abundant. Among localities which may be mentioned are Monte di Cuma and Monte di Procida in the Phlegrean Fields, and Monte Rotaro and Scanella on Ischia. It is noteworthy that this highly vitreous texture is never assumed by the same magma in the other districts where it occurs, the Auruncan and the Ciminian, where the phlegrose rocks are uniformly holocrystalline.

Name.-The type name is derived from Monte Rotaro, the locality of the type specimen. In prevailing classifications this type would, of course, be considered a trachyte-obsidian.

\section{ROTARAL PHLEGROSE. I. 5. 1. 3.}

Megascopic characters. - Compact, black sprinkled with white crystals, obviously highly vitreous, porphyritic. Phenocrysts of feldspar rather abundant, I to $5 \mathrm{~mm}$., stout prisms, white and colorless, prominent. Groundmass black or brownish black, highly vitreous, often with conchoidal fracture, sometimes rough.

Specific gravity, 2.44 .

Microscopic characters.-Dohyaline, mega- and micro-porphyritic, dopatic, mediophyric. Phenocrysts, about $\mathrm{I}_{5}$ per cent, feldspar. Groundmass: about 85 per cent, mostly glass, with some microphenocrysts of alkali-feldspar, augite and biotite.

Soda-orthoclase.-Megaphenocrysts: about 15 per cent; I to $5 \mathrm{~mm}$.; subhedral to euhedral, stout prismatic; Carlsbad twinning rare, inclusions rare. Microphenocrysts very variable, sometimes about 50 per cent, sometimes almost none; 0.10 to $0.30 \mathrm{~mm}$.; subhedral, prismatic, often branched in sheaflike forms; arrangement often subparallel.

Augite.-Microphenocrysts: about 2 per cent; 0. I to $0.2 \mathrm{~mm}$.; euhedral, prismatic; pale gray or very pale greenish.

Biotite.-Microphenocrysts: about I per cent, not always present; 0.05 to $0.02 \mathrm{~mm}$; ; thick tabular; brown, unaltered.

Glass.-About 80 per cent; usually brown, sometimes almost colorless. Sometimes dusty with minute, indeterminate microlites.

Chemical composition and norm as on p. 28 .

Type specimen from Monte Rotaro, Ischia. 


\section{5. 2. 2. Bolsenal Vulsinose [Vulsinite, Bolsena Type].}

As is stated elsewhere, this type is homologous texturally with the cumal type of phlegrose, differing from the arsal type just as the cumal differs from the ischial. Modally, on the other hand, the arsal and bolsenal vulsinose differ from ischial and cumal phlegrose by the presence of considerable anorthite or labradorite.

Megascopic characters. - These rocks are light gray, in specimens from one locality somewhat mottled with streaks of darker gray and yellowish. As the "schlieren" seem to be due rather to slight weathering than to essential differences in composition, they are not of sufficient importance to justify the separation of these specimens from the others as a distinct type. While the type is distinctly porphyritic, it is not conspicuously so, as in the preceding one. The phenocrysts, which are mostly of feldspar with fewer of augite and biotite, are small, from $I$ to 5 $\mathrm{mm}$. long, and not very abundant, making up not more than one-fifth of the rock volume. The feldspar and biotite phenocrysts are tabular, as usual, while those of augite are stoutly prismatic. The light-gray groundmass is aphanitic.

Microscopic characters. - The tabular phenocrysts of feldspar are seen in thin section to be of both orthoclase and anorthite, the former more abundant than the latter. They are both subhedral, with some crystal planes, occasionally fragmentary. Carlsbad twinning is common in the former feldspar, while the anorthite is often quite untwinned, though usually with multiple lamellæ. Zonal structure is not often seen, and inclusions are not very common, of augite, magnetite, apatite, and glass in both, and also of anorthite in the orthoclase. In many specimens the phenocrysts of both feldspars are surrounded by a border of alkali-feldspar substance of later growth, which is oriented parallel crystallographically with the inclosed crystal, extinguishes simultaneously all around it, and extends a short distance into the groundmass, without definite form. The augite phenocrysts call for little notice. They are mostly subliedral, in stout prismoids, of the usual pale-gray color so characteristic of the rocks of the region, and contain few inclusions of magnetite and of glass. The biotite phenocrysts are tabular, with irregular outlines, of a pale brown, and are uniformly much altered in the usual way. A few phenocrysts of magnetite, in irregular grains, may generally be seen.

The groundmass is holocrystalline and composed in great part of small prismoids of soda-orthoclase, which frequently have a subparallel arrangement, giving rise to a trachytic fabric. With them are some very small prismoids of colorless augite and still fewer small anhedra of magnetite. A little titanite and apatite are seen in accessory amounts, and some specimens show rare flakes and irregular areas of a pale-brownish hornblende; but none of these minerals can be considered as essential to the type. 
Chemical composition.-Analyses of bolsenal vulsinose are available from two occurrences. Those of the Bolsena rock were made on material from the same flow but of different specimens. One has already been published, but another analysis was made, since the former was only the second complete rock analysis which I had made, and a test of my work at that time was desirable. The results are satisfactorily concordant, especially when it is considered that they were made on different specimens of a somewhat eutaxitic lava. As none of the sample of powder from the first analysis was preserved, the figures for $\mathrm{TiO}_{2}$ and $\mathrm{P}_{2} \mathrm{O}_{5}$ given in II have been inserted in I, with proper corrections in the amount of $\mathrm{Al}_{2} \mathrm{O}_{3}$. This is not strictly accurate, but as both specimens come from the same flow, and the figures in question are small, the error can not be of importance, and the analysis as thus corrected and completed is undoubtedly more nearly in accordance with the facts than as it was originally published. The two analyses of the Astroni rocks by Riva have been used, as they show evidence of accuracy by correspondence with the descriptions and figures of the mode, and are satisfactorily complete.

Chemical Composition of Bolsenal Vulsinose [Vulsinite].

\begin{tabular}{|c|c|c|c|c|c|c|c|c|c|c|}
\hline \multirow[b]{2}{*}{$\mathrm{SiO}_{2} \ldots \ldots \ldots$} & \multicolumn{2}{|c|}{ I. } & \multicolumn{2}{|c|}{ II. } & \multicolumn{2}{|c|}{ III. } & \multicolumn{2}{|c|}{ IV. } & \multicolumn{2}{|c|}{ V. } \\
\hline & 58.21 & 0.970 & $57 \cdot 95$ & 0.966 & $5^{8.08}$ & 0.968 & $57 \cdot 5^{8}$ & 0.960 & $57 \cdot 50$ & $0.95^{8}$ \\
\hline $\mathrm{Al}_{2} \mathrm{O}_{3} \ldots \ldots$ & I 8.88 & .185 & I9.33 & . 89 & I9. I I & .187 & $19 \cdot 39$ & .190 & 18.80 & .184 \\
\hline $\mathrm{Fe}_{2} \mathrm{O}_{3} \ldots \ldots$ & 4.07 & .026 & 3.03 & .019 & $3 \cdot 55$ & .023 & 3.22 & .020 & $4 \cdot 37$ & .028 \\
\hline $\mathrm{FeO} \ldots \ldots \ldots$ & 0.87 & .013 & I. I 2 & .015 & 1.00 & .014 & 1.62 & .022 & 0.62 & .009 \\
\hline $\mathrm{MgO} \ldots . . .$. & 0.98 & .025 & $x \cdot I 2$ & .028 & I.05 & .026 & I.I 7 & .029 & I. 20 & .030 \\
\hline $\mathrm{CaO} \ldots \ldots \ldots$ & $3 \cdot 5^{8}$ & .046 & $3 \cdot 93$ & .070 & $3 \cdot 7^{6}$ & .067 & 4.08 & .073 & 3.84 & .069 \\
\hline $\mathrm{Na}_{2} \mathrm{O} \ldots \ldots$. & 2.57 & .042 & 3.10 & .050 & 2.84 & .046 & $3 \cdot 12$ & .050 & $3 \cdot 16$ & $.05 \mathrm{I}$ \\
\hline $\mathrm{K}_{2} \mathrm{O} \ldots \ldots$ & $9 \cdot 17$ & .098 & 8.55 & $.09 \mathrm{I}$ & 8.86 & .095 & 8.68 & .093 & 8.39 & .089 \\
\hline $\mathrm{H}_{2} \mathrm{O}+\ldots \ldots \ldots$ & ? 0.74 & & 0.54 & & 0.54 & & 0.50 & & $0.6 \mathrm{I}$ & \\
\hline $\mathrm{H}_{2} \mathrm{O}-\ldots \ldots \ldots$ & $\zeta^{0.74}$ & & 0. I I & & O. I I & & 0.44 & & $0.3^{8}$ & \\
\hline $\mathrm{CO}_{2} \ldots \ldots \ldots$ & none & & none & & none & & $\ldots$ & & $\ldots$ & \\
\hline $\mathrm{TiO}_{2} \ldots \ldots$ & 0.82 & .010 & 0.82 & .010 & 0.82 & .010 & 0.32 & .004 & $0.5^{\circ}$ & .006 \\
\hline $\mathrm{P}_{2} \mathrm{O}_{5} \ldots \ldots \ldots \ldots$ & 0.20 &.$\infty 01$ & 0.20 &.$\infty 01$ & 0.20 & $.00 \mathrm{I}$ & $0.2 \mathrm{I}$ &.$\infty O I$ & 0.28 & .002 \\
\hline 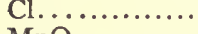 & $\cdots$ & & $\cdots$ & & $\ldots$ & & o. I7 & .005 & 0.03 & .000 \\
\hline \multirow[t]{2}{*}{$\mathrm{MnO} \ldots \ldots \ldots$} & n.d. & & n.d. & & n.d. & & $\cdots$ & & 0.57 & \\
\hline & 100.09 & & 99.80 & & $99 \cdot 92$ & & 100.49 & & $100.2 I$ & \\
\hline Sp. gr........ & 2.534 & $25^{\circ}$ & & & & & & & & \\
\hline
\end{tabular}

I. Bolsenal vulsinose [vulsinite]. Below castle, Bolsena, Vulsinian District. H. S. Washington, analyst. Jour. Geol., IV, $\mathrm{x} 896$, p. 552. $\mathrm{TiO}_{2}$ and $\mathrm{P}_{2} \mathrm{O}_{5}$ from II.

II. Bolsenal vulsinose [vulsinite]. Below castle, Bolsena, Vulsinian District. H. S. Washington, analyst.

III. Bolsenal vulsinose [vulsinite]. Below castle, Bolsena. Mean of I and II.

IV. Bolsenal vulsinose [vulsinite]. Caprara, Astroni, Phlegrean Fields. C. Riva, analyst. De Lorenzo and Riva, Att. Acc. Nap. Sci., XI, r9o2, p. 43.

V. Bolsenal vulsinose [vulsinite]. Pagliaroni, Astroni, Phlegrean Fields. C. Riva, analyst. De Lorenzo and Riva, Att. Acc. Nap. Sci., XI, I902, p. 48. 


\begin{tabular}{|c|c|c|c|c|c|c|c|c|c|}
\hline & III. & & & $\begin{array}{l}\text { Norms } \\
\text { IV. }\end{array}$ & & & & v. & \\
\hline Or.......... & $\left.5^{2.82}\right)$ & & & $5 \mathrm{I} \cdot 7 \mathrm{I})$ & & & $\left.49 \cdot 4^{8}\right)$ & & \\
\hline $\mathrm{Ab} \ldots \ldots \ldots$ & $23.06\}$ & $88.67)$ & & 21.48 & $\{86.8 \mathrm{I})$ & & $25.15\}$ & 86.86 ) & \\
\hline $\begin{array}{l}\text { An } \ldots \ldots \ldots \\
\text { Ne } \ldots \ldots \ldots \ldots\end{array}$ & $\left.\begin{array}{r}12.79 \\
0.57\end{array}\right\}$ & \} & 89.24 & $\begin{array}{r}13.62\} \\
1.08\end{array}$ & \{ & 89.02 & $\begin{array}{r}12.23 \\
0.85\end{array}$ & & $87 \cdot 7 \mathrm{I}$ \\
\hline $\mathrm{Hl}$........ & 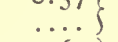 & 0.57 & & 0.23 & $2.21)$ & & .... & 0.851 & \\
\hline 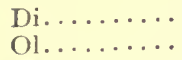 & $\left.\begin{array}{l}3.67 \\
0.63\end{array}\right\}$ & $\left.4 \cdot 3^{\circ}\right)$ & & $\left.\begin{array}{l}4.32 \\
c .63\end{array}\right\}$ & 4.95 & & $3.89\}$ & $4 \cdot 73 \mid$ & \\
\hline Mt ........... & $0.93)$ & & & $4 \cdot 18$ & & & $0.70\}$ & & \\
\hline Il . ......... & $\left.1.5^{2}\right\}$ & $5 \cdot 49\}$ & I0. I9 & $0.61\}$ & $5 . \mathrm{II}$ & 10.46 & $0.91\}$ & $5.6 \mathrm{I}$ & II.OI \\
\hline $\operatorname{Am} \ldots \ldots$ & $\begin{array}{l}3.04) \\
0.40\end{array}$ & $0.40)$ & & $\begin{array}{l}0.32) \\
0.40\end{array}$ & 0 & & $4.00)$ & 0671 & \\
\hline & & & & & & & & & \\
\hline est....... & $\begin{array}{r}99.43 \\
0.65\end{array}$ & & & $\begin{array}{r}99.48 \\
0.94\end{array}$ & & & $\begin{array}{r}98.72 \\
I .59\end{array}$ & & \\
\hline & 100.08 & & & 100.42 & & & 100.30 & & \\
\hline & & & & Ratios. & & & & & \\
\hline & & & Sal & & III. & IV. & v. & & \\
\hline & Class & & $\overline{\mathrm{Fem}}$ & & 8.76 & $8 \cdot 5 \mathrm{I}$ & $7 \cdot 97$ & & \\
\hline & Orde & & $\frac{F}{L}$ & & $=155 \cdot 44$ & $39 \cdot 28$ & I02. I9 & & \\
\hline & Rang & & $\underline{\mathrm{K}_{2} \mathrm{O}^{\prime}}$ & $+\mathrm{Na}_{2} \mathrm{O}^{\prime}=$ & 3.07 & 2.92 & 3.19 & & \\
\hline & Subra & & $\ldots \frac{\mathrm{K}_{2} \mathrm{O}}{\mathrm{S}}$ & & $=2.07$ & I. 86 & I. 74 & & \\
\hline
\end{tabular}

The very close correspondence of these rocks, from near the extremities of the volcanic zone, establishes the type of bolsenal vulsinose with great definiteness. As regards class, the ratios approach somewhat closely to the border of dosalane, though not near enough to justify us in calling the type transitional. The ordinal position in every case is well within the limits, the amount of normative lenads being entirely negligible. The ratios determining rang are almost exactly at the center point in all three analyses, but as regards subrang all three approach the border toward the third (sodipotassic) division. This is especially true of $\mathrm{V}$, which might be designated properly a pulaskose-vulsinose, though it would seem to be a rather hairsplitting matter to call it a separate type on this ground, when the other representative from the same volcano resembles it so closely.

Mode.-Complete estimation of the mode by Rosiwal's method was impossible, on account of the small size and confused arrangement of the constituents of the groundmass, as well as the error due to overlapping, although the phenocrysts could be measured with sufficient accuracy in the thin sections. The figures below are therefore based partly on Rosiwal measurements and partly on recalculation of the norm.

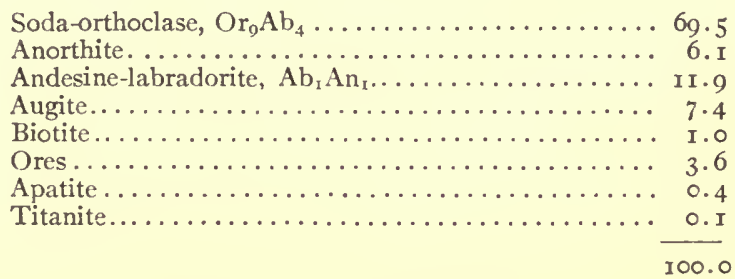


It is clear from this that considerable soda-lime feldspar must exist among the groundmass feldspar laths, which is indistinguishable from those of orthoclase, partly due to their small size and partly to the absence of twinning, which is not always pronounced even in the phenocrysts of anorthite. That the groundmass soda-lime feldspar must be considerably more sodic than the phenocrysts is shown by their lower refractive index, as well as from a consideration of the norm and the composition of the orthoclase, which can not be far from that stated above; that is, roughly $\mathrm{Or}_{2} \mathrm{Ab}_{\mathrm{I}}$. This leads to the assignment of the composition $A \mathrm{~b}_{\mathrm{I}} \mathrm{An}_{\mathrm{I}}$ to the groundmass plagioclase, rendering the average composition $\mathrm{Ab}_{\mathrm{I}} \mathrm{An}_{2}$. From the optical characters of the augite it is clear that none of the acmite molecule is present; in the readjustment of molecules for calculating this mineral it was assumed to have the composition of that from the Ticchiena albanose, the analysis of which is given later. The amount of $\mathrm{Al}_{2} \mathrm{O}_{3}$ thus set free by the transfer of $\mathrm{CaO}$ from normative anorthite to the wollastonite demanded by the augite is just about sufficient for the small amount of biotite present.

In general, the modal departures from the norm are of very small moment, so that the mode is a normative one, and the rock may be described as normative salphyro-vulsinose.

Occurrence.-The best-known locality of this type is at the town of Bolsena in the Vulsinian District, and it probably occurs elsewhere in the northern part of this district. Recently rocks of this type have been described by De Lorenzo and Riva from the Astroni Volcano in the Phlegrean Fields, and the same type is found in the Auruncan District, as in the valley east of Casi and near Torano, both near Teano.

Name.-The derivation of the subrang name has been already given, and that of the type is, of course, derived from the locality mentioned above.

In the prevailing systems of classification rocks of this type have usually been designated trachyte, though they differ from the true trachytes chemically in their lower silica and alkalis and higher lime, and modally in the presence of considerable labradorite or anorthite; and this abnormality has been commented on by almost every petrographer who has described them. On these grounds I proposed some years ago that they be separated from the true trachytes, as a separate group intermediate between the trachytes and basalts, and that they be called vulsinite, this name having been applied as well to the types known here as arsal vulsinose and arsal and bolsenal ciminose. While the separation of these types from the true trachytes and the bestowal of a distinctive name upon them has been criticized, the close accordance between the more numerous analyses which we now have of them, and their very marked dissimilarity in chemical composition from the typical "trachytes" of the older systems, as revealed by their norms and classification quantitatively, would seem to show that the separation and the use of the new name were amply justified. 
BOLSENAL VULSINOSE. I. 5. 2. 2.

Megascopic characters.-Light gray, sometimes mottled through darker schlieren, compact porphyritic. Feldspar phenocrysts rather abundant, I to $5 \mathrm{~mm}$., stout prisms, clear, glassy. Augite phenocrysts few, 0.5 to I mm., prismatic, black. Biotite phenocrysts very few, 0.5 to I mm., thin tabular, bronzy brown. Groundmass: light gray, aphanitic, rough fracture.

Specific gravity, 2.534 at $25^{\circ} \mathrm{C}$.

Microscopic characters.-Holocrystalline, megaporphyritic, dopatic, mediophyric. Phenocrysts: about 20 per cent, orthoclase, anorthite, augite, biotite. Groundmass: about 80 per cent, trachytic fabric, orthoclase, labradorite, augite, magnetite, apatite, titanite.

Soda-orthoclase, $\mathrm{Or}_{9} \mathrm{Ab}_{4}$.-Phenocrysts: about ro per cent, $\mathrm{x} .0$ to $5 \mathrm{~mm}$., subhedral, prismatic, Carlsbad twinning common, often surrounded by a mantle of later orthoclase substance extending irregularly into the surrounding groundmass. Groundmass: about 60 per cent, 0.05 to $0.2 \mathrm{~mm}$., anhedral, subprismatic and irregular, arrangement often subparallel.

Anorthite.-Phenocrysts: about 6 per cent, 0.5 to $3.0 \mathrm{~mm}$., subhedral, stout prismatic, often equant, usually multiply twinned, often surrounded by later mantle of orthoclase like alkali-feldspar phenocrysts. Groundmass: none, except as below.

Labradorite, $\mathrm{Ab}_{1} \mathrm{An}_{1}$. - Phenocrysts none. Groundmass: about $\mathrm{I} 2$ per cent, 0.05 to $0.20 \mathrm{~mm}$., subhedral, prismatic to irregular, arrangement subparallel. In many specimens there is no difference in composition between the plagioclase of the phenocrysts and of the groundmass, both having about the composition $\mathrm{Ab}_{\mathrm{r}} \mathrm{An}_{\mathbf{2}}$.

A ugite.-Phenocrysts: about 2 per cent, 0.2 to $\mathrm{I} .0 \mathrm{~mm}$., subhedral, stout prismatic and fragmentary, colorless or pale greenish-yellow. Groundmass: about 5 per cent, 0.01 to $0.03 \mathrm{~mm}$., anhedral, prismatic and equant, gray or pale yellowish.

Biotite.-Phenocrysts: about I per cent, 0.5 to $\mathrm{I} .0 \mathrm{~mm}$., subhedral, thin tabular, brown, usually altered. Groundmass, none.

Magnetite.-Groundmass: about 4 per cent, 0. or to $0.2 \mathrm{~mm}$., anhedral, equant.

A patite and titanite.-Very rare accessories, in minute crystals of usual form.

Chemical composition and norm as on p. $3 \mathrm{r}$.

Type specimen from below castle, Bolsena, Lake Bolsena, Vulsinian District.

\section{5. 2. 2. Viterbal Vulsinose [Leucite=Trachyte, Viterbo Type].}

With this type of vulsinose we meet the first of the long and interesting series of leucitic rocks for which the Roman Region is so famous, and which give it such a strongly marked petrographic character. The rocks to be now described, furthermore, exhibit a habit which is one of the best marked in the region and which rivets the attention of every geologist. The assumption of this leucitic mode by a persalic magma is of some interest, as leucite rocks are, for the most part, of the dosalane or salfemane classes.

Megascopic characters. - The rocks, which would be called leucite-melaphyres in the field, are characterized especially by the abundance and size of the phenocrysts of leucite. These constitute about 40 per cent of the rock volume, and vary in diameter from 2 to $\mathrm{r}_{5} \mathrm{~mm}$., with an average of about $8 \mathrm{~mm}$. These leucites are highly euhedral trapezohedra, though sometimes fragmentary through breaking up during the flow of lava. They are lightly spotted with black inclusions of augite and glass, and carry as well some inclusions of labradorite, which are not distinguishable mega- 
scopically. Owing to their white color, their size, and the generally rather dark shade of the groundmass, these phenocrysts stand out very prominently and give the rocks of this and homologous types a most characteristic appearance-so much so that they have the popular name of "fish-eye" (occhio di pesce). Accompanying these leucites, but very inconspicuously, are a few much smaller phenocrysts of feldspar (mostly labradorite) and augite. The aphanitic groundmass is a rather dark ash-gray.

The habit of these and homologous types, characterized by abundant, large, euhedral leucite phenocrysts, with only very small amounts of small augite phenocrysts, and a rather light to rather dark gray aphanitic groundmass, may be called "viterboid." Microscopically the groundmass may or may not show some leucite, as it does in the homologous type of vicose, the relative proportions of alkali- and soda-lime feldspars in the groundmass may vary considerably, the former being usually the more abundant, and the fabric may be more or less trachytic. But these differences are microscopic, and it would not seem advisable at present to regard them as of sufficient importance to determine different habits.

Microscopic characters. - In thin section the large leucites show the usual double refraction and twinning, which are very well marked unless alteration has set in. Inclusions of augite, labradorite, magnetite, and glass are not uncommon. The less abundant feldspar phenocrysts are mostly of orthoclase, with some of labradorite. They are in the form of stout subhedral prismoids, often with numerous glass inclusions, mostly clustered toward the center. The augite phenocrysts are mostly well formed crystallographically, and are of the usual very pale gray, with only a slight tinge of green and non-pleochroic. The groundmass is holocrystalline, composed in very large part of small orthoclase prismoids, whose arrangement is diverse, forming a felted fabric. With these are small quantities of minute augite prismoids, some biotite flakes interstitial between the feldspar laths, magnetite grains, and an occasional small apatite and titanite. A few of the specimens which are of this type contain small amounts (not more than 2 per cent) of leucite in the groundmass, as very small, clear, equant euhedra, in this respect being transitional toward the viterbal vicose to be described later.

Chemical composition.-Two analyses were made of viterbal vulsinose and are presented below, along with one of bolsenal vulsinose for comparison. The second of these was made and published some years ago, though additional determinations of minor constituents have been made since. It differs from the other in several respects, notably in lower alkalies and alumina, and higher oxides of iron, lime, and magnesia. As will be seen when the mode is under discussion, there is strong reason for the belief that the sample analyzed was not representative of the rock, but contained less of the leucite phenocrysts and more of the groundmass. For this reason the analysis of the Grignano rock is to be regarded as the most typical. 
Chemical Composition of Viterbal Vulsinose [Leucite-trachyte].

\begin{tabular}{|c|c|c|c|c|c|c|}
\hline & I. & & I & & III. & IV. \\
\hline 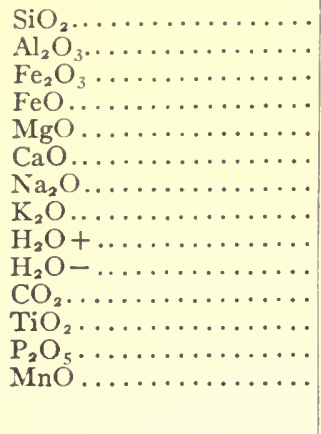 & 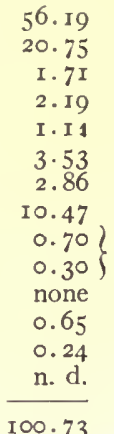 & $\begin{array}{r}0.936 \\
.203 \\
.011 \\
.031 \\
.029 \\
.063 \\
.046 \\
.112 \\
\\
.008 \\
.002\end{array}$ & $\begin{array}{r}55.17 \\
\text { I } 9.60 \\
3.27 \\
2.74 \\
1.5^{8} \\
3.73 \\
2.27 \\
9.5^{8} \\
0.99 \\
\text { none } \\
0.69 \\
0.20 \\
\text { n. d. } \\
00.82\end{array}$ & $\begin{array}{r}0.920 \\
.192 \\
.020 \\
.038 \\
.040 \\
.067 \\
.037 \\
.102\end{array}$ & 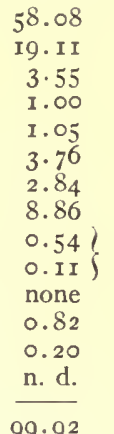 & $\begin{array}{r}58.48 \\
\text { I } 8.56 \\
2.03 \\
3.16 \\
0.53 \\
2.60 \\
3.14 \\
10.47 \\
0.24 \\
\ldots . .70 \\
0.70 \\
0.30 \\
\cdots . . \\
100.21\end{array}$ \\
\hline
\end{tabular}

I. Viterbal vulsinose [leucite-trachyte]. Sorgente di Grignano, southwest of Lake Vico, Ciminian District. H. S. Washington, analyst.

II. Viterbal vulsinose [leucite-trachyte]. Below San Rocco, Monte Vico, Ciminian District. H. S. Washington, analyst. Jour. Geol., V, I897, p. 370 . Additional determinations here.

III. Bolsenal vulsinose [vulsinite]. Bolsena, Vulsinian District. (Cf. p. 3I.)

IV. Bagnoreal vulsinose [leucite-trachyte]. Monte San Antonio, Auruncan District. vom Rath, analyst. Zeits. d. d. geol. Ges., XXV, I873, p. 244. $\mathrm{Fe}_{2} \mathrm{O}_{3}, \mathrm{FeO}, \mathrm{TiO}_{2}$, and $\mathrm{P}_{2} \mathrm{O}_{5}$ estimated by $\mathrm{H}$. S. WV.

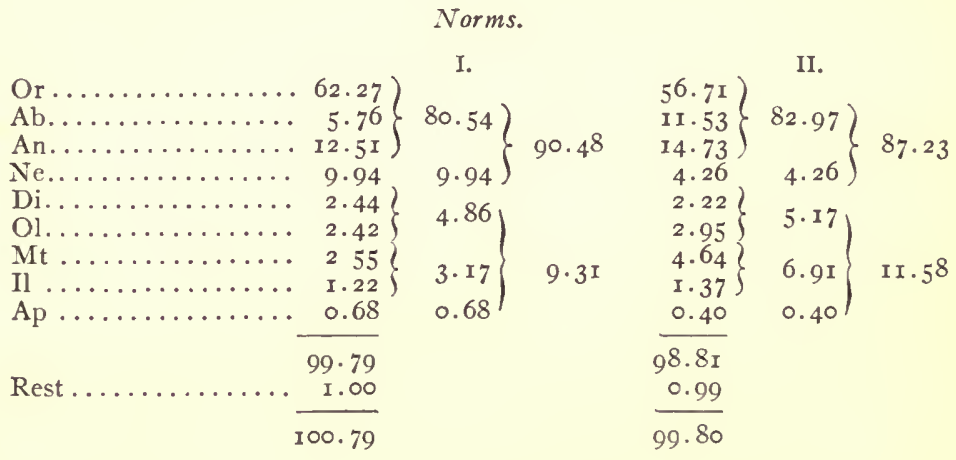

Ratios.

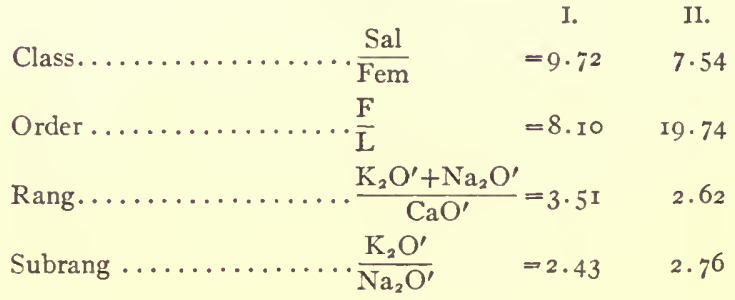


Comparison of the analysis of this leucitic type (I) with that of the non-leucitic (III) is of interest. While they are closely similar in the figures for alumina, iron oxides, magnesia, lime, and soda, the silica of $I$ is lower by about 2 per cent, and potash higher by about I.6 per cent. These differences are not very great, but they are concordant, and sufficient to have determined (it may be concomitantly with the physical conditions) the formation of modal leucite in the one and its absence in the other. At the same time, it must be understood that modal leucite could have formed from the magma of III, as is clear from consideration of the norm, though only to a comparatively small extent, limited by the small amounts of normative nephelite and olivine which this type shows.

The analysis in IV has been corrected by me from vom Rath's original one in regard to the oxides of iron, titanium, and phosphorus, the corrections being based on an analysis of mine of a leucite rock from the same locality. It will be discussed later.

Mode.-The measured mode of I was determined both megascopically and microscopically, the phenocrysts of leucite having been measured on the surfaces of a good-sized hand specimen and those of labradorite and augite, with the constituents of the groundmass, in the thin section. For the calculated mode the composition of augite was assumed to be that occurring in the Ticchiena albanose, as in the preceding case, and that of the biotite to be about equal parts of leucite and olivine. This last is not strictly correct, but the error will be slight in view of the small amount of this mineral present.

\begin{tabular}{|c|c|c|c|c|}
\hline & Calculated. & MEAS & JRED. & \\
\hline 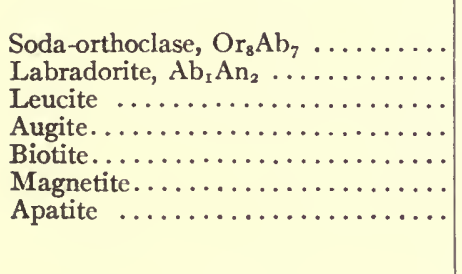 & $\begin{array}{r}39.6 \\
\text { I } 7 \cdot 5 \\
31.4 \\
5 \cdot 3 \\
2.3 \\
3 \cdot 2 \\
0.7 \\
100.0\end{array}$ & $\begin{array}{l}\text { Vol. \%. Sp. gr. } \\
42.0 \times 2.6= \\
11.0 \times 2.7= \\
38.0 \times 2.5= \\
5.4 \times 3.3= \\
2.0 \times 2.9= \\
1.6 \times 5.2= \\
\ldots . \\
100.0\end{array}$ & $\begin{array}{r}109.20 \\
29.70 \\
95.00 \\
17.82 \\
5.80 \\
8.3^{2} \\
\ldots \cdots \cdots \\
265.84\end{array}$ & $\begin{array}{r}\text { Wt. \%. } \\
4 \mathrm{I} . \mathrm{I} \\
\text { II. } \\
35 \cdot 7 \\
6.7 \\
2.2 \\
3 \cdot \mathrm{I} \\
\ldots \cdots \\
\text { I00.0 }\end{array}$ \\
\hline
\end{tabular}

It will be seen that the correspondence is fairly close for most of the constituents, especially when the very fine grain of the groundmass is taken into consideration. The only marked discrepancies are in the amounts of labradorite and leucite, which are respectively lower and higher in the measured mode. The former is probably due in part to the presence of some labradorite inclusions in the leucite phenocrysts, which were not reckoned in, and also in part to the possible presence of some lime-soda feldspar among the groundmass laths. The measured leucite must, of course, be diminished by the amount of labradorite which it includes, as well as by the small quantities of augite and glass inclusions, whose exact amount could not 
be definitely ascertained, as most of the leucites were much broken in the sections and their inclusions lost. Of the two modes, that calculated from the norm is regarded as the more reliable and the nearer approximation to the true composition.

From these it is clear that the modal deviations from the norm due to alferric minerals are inconsiderable, but that the essential difference lies in the modal leucite replacing a negligible amount of normative nephelite. The relations of mode and norm are of especial interest as illustrative of the possibility that a rock belonging to a perfelic order may carry modally about 30 per cent of the lenad leucite. This will be adverted to in a later discussion. From the description of the rock and the relation of the mode to the norm, the type may be described as a leucite-salphyro-vulsinose.

The mode of II was less satisfactorily estimated by Rosiwal's method, and as thus determined agrees far less closely with that calculated from the norm. The leucite phenocrysts were determined by measurements on the surfaces of the hand specimen, and those of feldspar and augite phenocrysts in thin section, both as compared with the groundmass as a whole. Attempts to estimate the relative amounts of the minerals in this last were unsatisfactory, because of their very small size and the consequent large error due to overlapping. As thus determined the mode may be stated as follows:

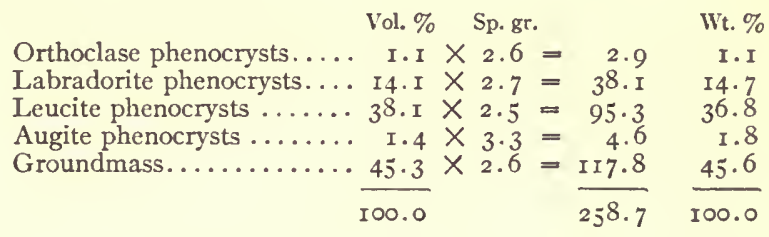

Comparing this with the Rosiwal mode of the Grignano rock, it is seen that the amounts of leucite phenocrysts in both are almost alike, and as these could be measured with considerable accuracy, it must be assumed that the measured amounts of this mineral are very close to the truth, though slight corrections must be made for the small quantities of inclusions which the large phenocrysts carry, and which it was not practicable to estimate.

The mode was also calculated from the norm by the usual process of successive readjustments, all the normative olivine being changed to hypersthene, which enters into modal augite, and the normative nephelite taking silica enough to form albite, which enters into modal alkali-feldspar and labradorite. In this way we obtain the maximum amount of molecules of minerals as highly silicated as possible, leaving as little silica as possible to combine with potash in orthoclase and leucite, the amounts of which are thus theoretically fixed and can be calculated by the equations given in the "Quantitative Classification" on page r94. We must thus obtain the maximum amount of leucite capable of formation from the magma, as, if more were assumed to be present, some silica would necessarily be set free, which is contrary to the actual facts. 
In this way the following calculated mode was obtained:

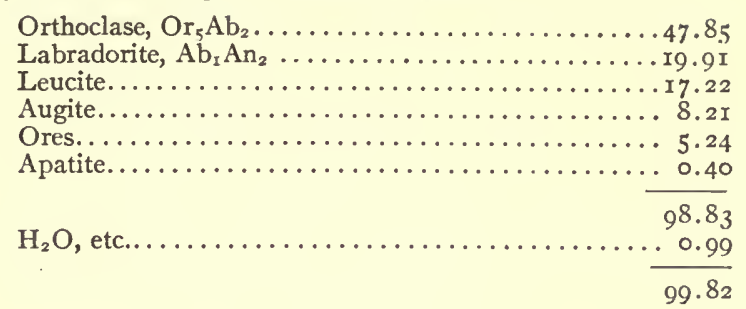

It is clear that the discrepancy between the observed and the calculated amounts of leucite, 36.8 and 17.2 per cent, can not be explained by the corrections needed for inclusions, and it has been shown above that the larger amount of leucite as revealed by Rosiwal's method must be close to the truth. As, furthermore, by no possible means can more leucite be calculated frorn the magma without setting silica free, and there is no reason to believe that the analysis is seriously incorrect, it follows that the only allowable explanation of the discrepancy is that the sample analyzed did not correspond to the rock as a whole, but contained an unduly large amount of groundmass and an unduly small amount of the leucite phenocrysts.* That this explanation is the correct one is the more probable when it is considered that the analysis was made by me some eight years ago, when the importance of crushing up a sufficiently large piece of rock had not impressed itself upon me, and when the coarsely porphyritic character of the rock and of the brittleness of the leucite phenocrysts are taken into account. If a rather small piece was taken, it would be probable that the sample analyzed would contain relatively more groundmass than the rock itself. This conclusion is borne out by the fact that the modes of the San Rocco specimen show considerably more of the groundmass constituents than in the other specimen. Attention is called to this otherwise rather unimportant point, as it serves to emphasize a feature of the analysis of rocks-the proper preparation of the sample - on which I have laid stress elsewhere. $\dagger$ In view of the conclusions above, the analysis (II) of the San Rocco vulsinose can not be considered as representative of the rock magma, and must be disregarded in future discussions.

Occurrence.-This type has been found with certainty only in the Ciminian District, where it is very abundant, many of the lava flows of the Vico Volcano belonging here. Among localities where especially good specimens were collected may be mentioned several flows in the east inner wall of Monte Vico below San Rocco, flows near San Martino, northwest of Lake Vico, especially above the church and below the town at the Contrada di Merlano, and southwest of Lake Vico, as at the Sorgente di Grignano and the Ponte delle Cese.

* As the silica percentage of leucite is 55.05 , and therefore close to that of the rock, the removal of leucite would not materially affect the silica shown by the analysis.

†H. S. Washington, P. P. 14, U. S. G. S., p. 18, 1903; and The Chemical Analysis of Rocks, New York, 1904, p. 47. 
The type may also occur in the Auruncan District. The analysis of a "leucite-trachyte" by rom Rath given in column IV is that of a vulsinose and with a leucitic mode. A rock with prominent leucite phenocrysts collected by me at this locality shows much less silica ( 5 r.20) and falls in vicose (II. 6. 2.2), and is clearly not the same as vom Rath's rock, as his silica determination can not be so greatly in error. His description is not very clear or detailed, but it may be gathered that the mode is probably closely like that of the bagnoreal ciminose and vicose, to be described later, in which the leucite phenocrysts are much less abundant and less prominent, and with more numerous augite phenocrysts. I have therefore assigned vom Rath's rock provisionally to the type of bagnoreal vulsinose, though this needs further investigation. The descriptions of Bucca lead one to believe that true viterbal vulsinose is quite abundant in the Auruncan District, as at the localities of Valogno Piccolo and below Orchi. I did not visit the former locality, and the rocks which I collected near the latter village are not of this type.

Name.-The type adjective, viterbal, is derived from the city of Viterbo, the chief town of the Ciminian District. In prevailing classifications rocks of this type have gone under very different names. If we disregard the small amount of labradorite, which is always subordinate to the orthoclase, the rocks would be called by Zirkel leucite-trachytes, and by Rosenbusch leucite-phonolites. Of these two, that of Zirkel is the better, in my opinion, for reasons given elsewhere. Some petrographers, however, regard the presence of the labradorite as of more importance than that of the more abundant orthoclase, and therefore call these rocks leucitetephrites. Of this appellation it may be remarked that it is at variance with the quantitative relations of the two feldspars, ignoring that which is most abundant and laying special stress on the subordinate one. It may also be noted that these rocks differ widely from others of the region to which the name of leucite-tephrite is applied with as much logical reason as the prevailing systems are capable of. Under the prevailing systems, however, there is no means of distinguishing this well-marked type from others in which the leucite is not decidedly porphyritic. The characters are so well marked and so easily recognizable, and these rocks are so important in the petrography of the region, that they would seem to be deserving of a separate name. For this the term viterbite may be used.

\section{5. 2. 2. Pallanzanal Vulsinose [Leucite-Trachyte, Pallanzana Type].}

This type is intermediate between the bolsenal and viterbal types. It resembles the former in the rather small and rare feldspar phenocrysts and the latter in the presence of phenocrysts of leucite, though these last are much smaller and far less abundant than in the rocks just described.

The rocks are all more or less decomposed, being so friable that it was impossible to obtain good specimens, and it is noteworthy that all writers mention the uniformly altered condition. On this account no analysis was made of them, so that their exact magmatic position is not sure. Microscopic study, however, ren- 
dered it evident that at least the majority of the occurrences fall in vulsinose, so that, as a description is called for on account of their importance in the Ciminian District, it may be inserted here.

The rocks are light gray, megaphyric, and dopatic to perpatic. The majority of the phenocrysts are of feldspar, mostly of orthoclase, but with about half as much labradorite. These are up to 20 or $30 \mathrm{~mm}$. in length and euhedral to subhedral tabular. The feldspar phenocrysts constitute from ro to 15 per cent of the rock. Phenocrysts of leucite are less numerous, making up not more than about 5 per cent of the rock. They vary from 5 to $10 \mathrm{~mm}$. in diameter, are anhedral equant, and always a dull white through kaolinization. Very few phenocrysts of augite and biotite are also present, of about the size of the leucites.

The groundmass is either very fine grained or aphanitic, and is quite often somewhat vesicular, though never scoriaceous. It is also holocrystalline and closely resembles that of the bolsenal type, composed in very large part of small laths of orthoclase, which have a subparallel arrangement. With these are a very few small ( 0.05 to $0.01 \mathrm{~mm}$.), round spots of colorless, isotropic substance, which is probably to be referred to leucite. Their amount, however, is negligible. There are the usual small prismoids and irregular grains of colorless augite, and fewer of magnetite, but none of the interstitial biotite seen in the preceding phase. Here this mineral seems to have developed entirely as phenocrysts.

The occurrence of these rocks is confined to the Ciminian District, where they are rather common, being known locally as "petrisco." The typical "petrisco" is best developed in the northeastern part of the district, where it forms extensive flows from the Vico Volcano. The largest of these originated apparently on the north flank of Vico, and passed northward around Monte Pallanzana, which divided it into two branches. From this flow characteristic specimens were obtained by me at the Villa Lante near Bagnaia and at Cavorcie on the north branch and at I Cappuccini on the south branch, as well as from other localities. Mercalli describes several flows of "petrisco" on the east and south of Monte Vico, between Capranica and Ronciglione, but whether they are strictly of this type or not is uncertain, as I was unable to visit them.

As stated above, no analysis was made of this type, on account of the weathered condition of all the specimens, so a formal description is uncalled for.

\section{6-5. 2. 3. Paglial Procenose-Pulaskose [Leucite-Trachyte, Paglia Type].}

Megascopic characters.-In the hand specimen the rocks of this type are much like those of the type of sabatinal beemerose to be described later, the main difference being the somewhat darker groundmass. They are medium gray in color, very compact, and markedly porphyritic. Leucite phenocrysts are not very numerous, making up but about one-tenth of the rock, but they are conspicuous and quite large, from 5 to $20 \mathrm{~mm}$. in diameter. Most of them show crystal planes, but all are more or less fragmentary, so that completely bounded trapezohedra are very 
rare. Their color is inclined to yellowish, the luster is apt to be somewhat waxy, and they are mostly quite free from inclusions. There are also very few large ( Io to $20 \mathrm{~mm}$. long), stout prismoids of feldspar, which the microscope proves to be of orthoclase, and some smaller ones of what the thin section shows to be labradorite. In addition are very few and small prismoids of black augite, so inconspicuous as almost to escape notice. The groundmass is a rather dark ash gray, and quite aphanitic.

Microscopic characters.--In thin sections the larger leucite phenocrysts have generally fallen out, but the fragments left show the usual double refraction and twinned structure. One or two sections of the large feldspar phenocrysts show that they are of orthoclase, undoubtedly sodic, while the smaller ones are of labradorite, about $\mathrm{Ab}_{\mathrm{I}} \mathrm{An}_{2}$. These last are much twinned, and are usually gathered into clusters, whose numbers are greater than those of the orthoclase phenocrysts. The phenocrysts of augite are subhedral or anhedral, mostly in stout prismoids or fragments, and of the usual pale-gray tint.

The groundmass is holocrystalline, and the fabric is, on the whole, trachytic, though not as typically so as in many otlier types, on account of the presence of considerable numbers of formless anhedra of orthoclase and rounded leucites. It is composed very largely of feldspar, for the most part in slender prisms or laths, of which the majority are of orthoclase with fewer of labradorite, though it was impossible to arrive at any satisfactorily accurate estimate of the relative amounts. As noted above, anhedral individuals of orthoclase also occur. Leucite is present in considerable amount as small, round anhedra, defined by the rings of augite and magnetite grains and feldspar laths surrounding them, and identifiable by the faint double refraction. Scattered through the mass are the usual small prismatic anhedra of colorless augite, equant anhedra of magnetite, and rare apatite prisms. Neither nephelite nor glass could be detected, and the sodalite minerals seem to be wholly absent.

Chemical composition.--For the analysis a fair-sized hand specimen was crushed and sampled, in order to obtain a representative powder, on account of the large size of the leucite phenocrysts. With the analysis of mine is given one by Ricciardi of a rock also from Proceno, called a leucite-tephrite by Klein, whose description agrees in the main with that of the specimen analyzed by me. There is also given an analysis by Riva of a bolsenal vulsinose-pulaskose (vulsinite) from the Astroni Volcano in the Phlegrean Fields.

The analysis itself does not call for special remark, except that the considerable amount of $\mathrm{BaO}$ and the presence of small quantities of zirconia, strontia, and the "rare earths" may be noted. These last were determined with care by Hillebrand's method,* and there is probably little doubt that they exist in similarly small amounts in other rocks of the region, as they were also found to be present in a more femic rock.

* W. F. Hillebrand, Bull. I;6, U. S. Geol. Surv., p. $77,1900$. 
Chemical Composition of Paglial Procenose-pulaskose [Leucite-trachyte].

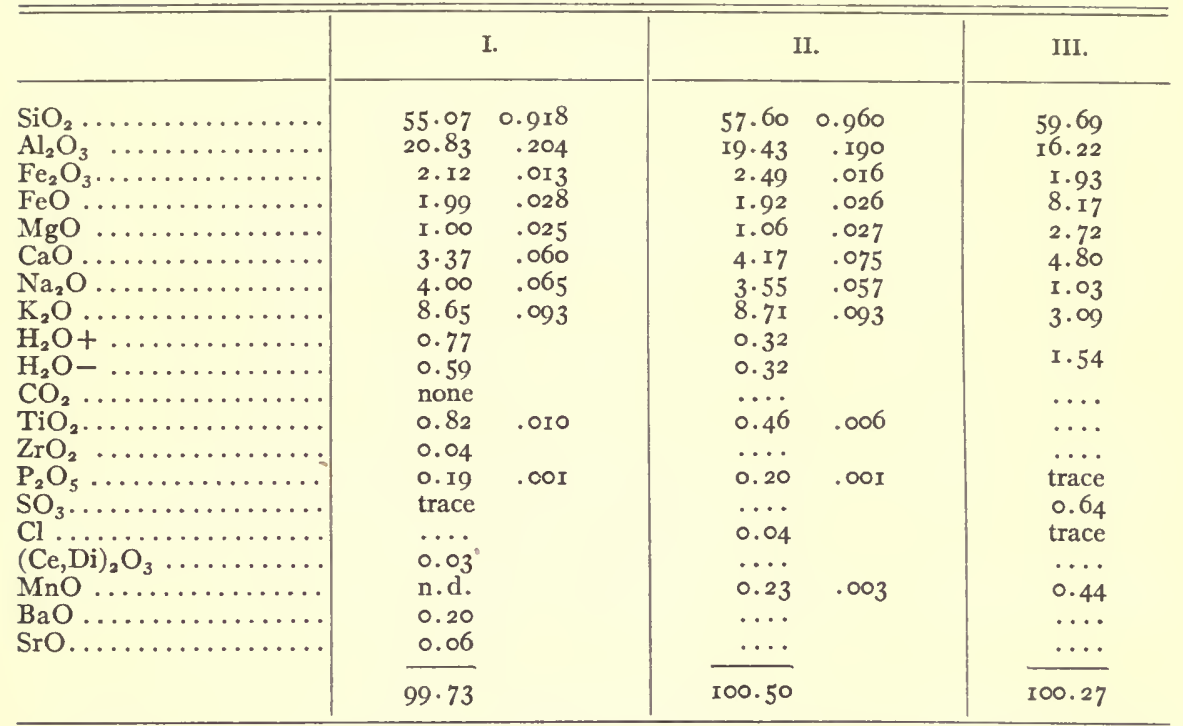

I. Paglial procenose-pulaskose [leucite-trachyte]. Below castle, Proceno, N. W. of Lake Bolsena, Vulsinian District. Washington, analyst.

II. Bolsenal vulsinose-pulaskose [vulsinite]. Rotondella, Astroni Volcano, Phlegrean Fields. Riva, analyst. De Lorenzo and Riva, Att. Acc. Sc. Nap., XI, 1902, p. 52.

III. Paglial pulaskose? ["Ieucite-tephrite"]. Below castle, Proceno. Ricciardi, analyst. Klein, Neu. Jahrb., B. B. VI, I889, p. 26.

Norm of $I$.

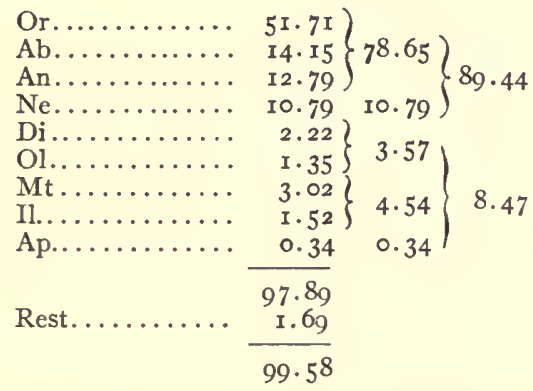

Ratios.
Norm of II.

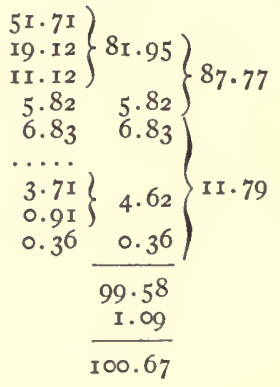

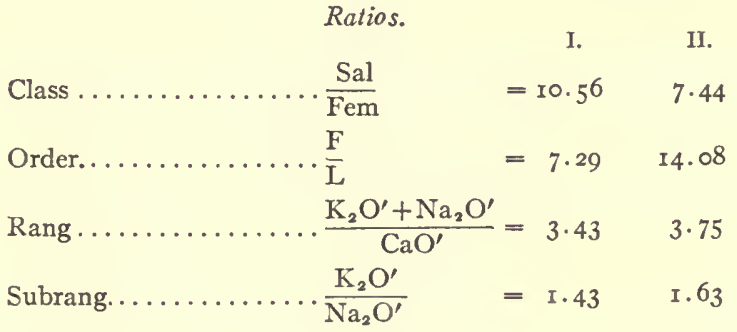


From the figures of the norm and the ratios it is seen that the rock falls well within the persalane class and the domalkalic rang, and fairly well within the sodipotassic subrang, though somewhat close to the dopotassic border. But it is almost exactly on the line between the perfelic and lendofelic orders, falling in order 5 or 6 according to whether the small amount of apatite is calculated in the norm or not. It is therefore eminently a transitional one belonging strictly in pulaskose, I. 5. 2. 3, but very close to the border of the subrang I. 6. 2. 3, as yet unnamed, which may be called procenose, from the locality of the specimen analyzed. The magmatic name then will be procenose-pulaskose.

The analysis of the Astroni rock in II resembles the other very closely, except in containing 2.5 per cent more silica. This larger amount, by increasing the quantity of normative albite and diminishing that of normative nephelite, removes the type well away from the border of order 6, while, like the preceding, it falls well within class I and rang 2. On the other hand, the ratio of soda to potash brings it very near the line of dopotassic subrang 2 , so that this type must be regarded as a vulsinose-pulaskose. It will be remembered that the other rocks of the Astroni Volcano fall in rulsinose, one, indeed, being strictly a pulaskose-vulsinose.

The analysis by Ricciardi in III must be of a rock almost, if not quite, the same as that analyzed by me, as Klein's description agrees with mine in all essential respects, and the town of Proceno is built upon but one thick lava flow, from which the two specimens must have come. It will be seen that here, as in so many other of the same chemist's analyses, the amounts of the alkalis reported are quite irreconcilable with the mode of the rock. Thus the potash reported would allow the formation of but 18.35 of orthoclase or 14.39 of leucite, and the silica is so high that it can not be satisfied by the bases present, and the rock would necessarily contain considerable amounts of quartz. Indeed, the discrepancy is so marked that Klein comments on the apparently low figure for alkalis.

Mode.-Estimation of the mode of the paglial procenose-pulaskose could be carried out by Rosiwal's method only as far as the phenocrysts and the dark minerals were concerned. The feldspar laths of the groundmass were far too fine and confused in arrangement to allow of separate estimation of the orthoclase and the labradorite. The amount of the large leucite phenocrysts (I0.4 per cent by volume) was determined in the hand specimen, while the thin section was used for those of the groundmass and the other constituents. The results may be thus tabulated:

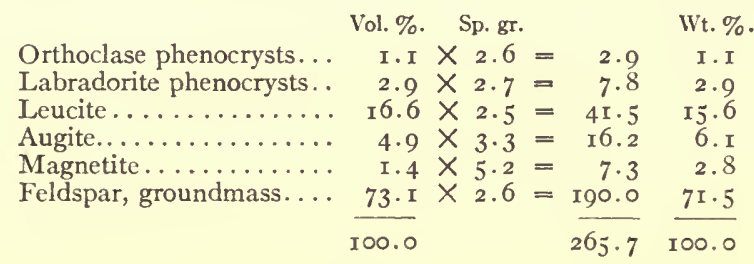

In calculating the mode from the norm it will be found that if all the nephelite is assumed to take up silica to form modal albite there must result 36.2 per cent of 
leucite and only 5.6 per cent of orthoclase. These amounts are obviously incorrect, as the amount of leucite shown by Rosiwal's method can not be so far from the truth, since this mineral is mostly in the form of phenocrysts and is easily measurable. If we then assume that the amount of leucite is that given above I6.6 per cent and that all the olivine molecules enter as hypersthene into the augite, we shall obtain the following results:

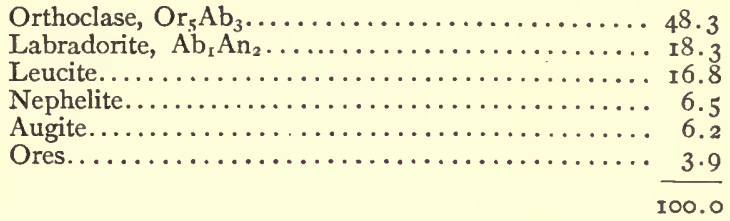

This calculated mode may be regarded as closely correct, though it differs from the microscopic description in the presence of nephelite. The amount of this, however, is small, and it could easily be overlooked among the closely packed feldspar laths. After attention was directed to its probable presence, examination under high powers revealed some colorless interstitial cement, with weak birefringence, which may well be this mineral.

The deviation of the mode from the norm is therefore considerable, but is especially marked in the presence of abundant leucite, replacing some of the normative orthoclase and nephelite, much of the latter becoming albite and entering the feldspars. The readjustments due to alferric minerals are negligible. The rock may therefore be described as a leucite salphyro-procenose-pulaskose.

Occurrence.-The most important occurrence of the type of paglial procenosepulaskose is the very extensive flow which, issuing from the Latera Volcano in the northwestern part of the Vulsinian District, flowed north and ended at the Paglia River, near Proceno and Acquapendente. The specimen analyzed came from below the castle of Proceno, but specimens of the same type were obtained by me from elsewhere in the flow. From the descriptions of Bucca and Klein it is probable that the same type, or similar ones, occur at Gradoli, Monte Calveglia, Poggio Pilato, and elsewhere around the Latera Volcano, though I can not confirm this supposition definitely by actual specimens, as I was prevented from visiting these localities. The same type was also found by me at Monte Bisenzo, on the southwest shore of Lake Bolsena, though the majority of the rocks of this locality belong to other types and magmas.

Name.-The derivations of the subrang names have been explained elsewhere, and that of the type is derived from the Paglia River, at which the flow composed of the type ends--the most prominent geographical feature of the neighborhood.

The rocks of this type are nearly always referred to as leucite-tephrite by the Italian and German petrographers, on account of their content in labradorite. Such a designation, however, exaggerates the importance of this constituent at the expense of the very much more abundant orthoclase. Furthermore, these rocks, with their large leucite phenocrysts and rather light-gray groundmass and abundant 
orthoclase, differ widely in texture and mode from the other rocks of the region to which the name tephrite is applied, and which contain abundant labradorite, practically no orthoclase, few and small leucite phenocrysts, and with a dark-gray groundmass. For these reasons the name of leucite-trachyte is the more appropriate.

PAGlial PROcenosepulas=Kose. I. 6-5. 2. 3.

Megascopic characters. - Light gray, compact, porphyritic. Leucite phenocrysts not very abundant, 5 to $20 \mathrm{~mm}$. in diameter, fragmentary, and with crystal planes, not many inclusions. Feldspar phenocrysts, few, some ro to $20 \mathrm{~mm}$. long, stout prismatic, mostly small and inconspicuous; augite phenocrysts, very few, very small, prismatic, black. Groundmass: medium gray, aphanitic.

Microscopic characters.-Holocrystalline, megaporphyritic, megaphyric and microphyric, dopatic. Megaphenocrysts: about I5 per cent, leucite, labradorite, orthoclase, augite. Microphenocrysts: about 6 per cent, leucite. Groundmass: about 80 per cent, trachytic fabric; orthoclase, labradorite, augite, nephelite, magnetite.

Orthoclase, $\mathrm{Or}_{5} \mathrm{Ab}_{3}$.-Phenocrysts: about I per cent, ro to $20 \mathrm{~mm}$., subhedral, stout prismatic. Groundmass: about 50 per cent, 0.05 to $0.20 \mathrm{~mm}$., anhedral, prismatic, arrangement subparallel.

Labradorite, about $\mathrm{Ab}_{1} \mathrm{An}_{2}$.-Phenocrysts: 3 per cent, glomerophyric, clusters of anhedral, stout prisms, clusters 0.5 to $2.0 \mathrm{~mm}$. in diameter, commonly twinned. Groundmass: about 15 per cent, 0.05 to $0.20 \mathrm{~mm}$., anhedral, prismatic, arrangement subparallel.

Leucite.-Megaphenocrysts: Io per cent, 5 to $20 \mathrm{~mm}$., subhedral, mostly fragmentary, equant to irregular, few inclusions, of augite and labradorite. Microphenocrysts: about 6 per cent, 0.1 to $0.2 \mathrm{~mm}$., anhedral, equant, inclusions rare.

Augite.-Phenocrysts: about 2 per cent, 0.5 to $1.0 \mathrm{~mm}$., anhedral to subhedral, prismatic, pale greenish-gray, inclusions few. Groundmass: about 4 per cent, 0.02 to $0.05 \mathrm{~mm}$., anhedral, prismatic, colorless.

Nephelite.-Groundmass: about 6 per cent, anhedral, interstitial cement.

Magnetite.-Groundmass: about 2 per cent, 0.01 to $0.02 \mathrm{~mm}$., anhedral, equant.

Analysis and norm as on p. 43 .

Type specimen from below castle, Proceno, northwest of Lake Bolsena, Vulsinian District.

\section{6. 1. 3. Sabatinal Beemerose [Leucite=Phonolite, Sabatino Type].}

Megascopic characters.-Rocks of this type are very light gray and markedly porphyritic, showing rather numerous large phenocrysts of leucite, with many minute ones of augite. The leucite phenocrysts, which vary in diameter from 2 to Io mm., are usually anhedral and with irregular outlines, though they sometimes show crystal planes. In the type specimen they are slightly yellowish, but they may be normally considered as colorless. The small augites are stoutly prismatic, and very dark green or black. The ash-gray groundmass is quite aphanitic.

Microsco pic characters. - In thin section the large leucite phenocrysts show the twinned structure very well. The augite phenocrysts are subhedral, in stout prisms, of a rather deep olive-green, and with the optical characters of ægirite-augite.

The groundmass is holocrystalline and shows a confused fabric, due to the diverse arrangement of the short, stout prisms of alkali-feldspar of which it is very largely composed. These are either twinned according to the Carlsbad law, or more often simple crystals, and lime-soda feldspar seems to be entirely wanting. There are also many small, round anhedra of leucite, which are not infrequently changed to 
the so-called pseudoleucite, a mixture of orthoclase and nephelite. Small, mostly colorless haüynes are seen here and there, with the customary dusty inclusions. Small prismatic anhedra of ægirite-augite and grains of magnetite are present in very small amount, and crystals of apatite and titanite are still more rare. Acting as a cement for these is some nephelite, which is the last product of crystallization.

Chemical composition.-An analysis of this type, published some years ago in incomplete form, is given in I below, with a number of additional determinations. Two of the few other analyses of beemerose rocks are also presented in II and III.

Chemical Composition of Sabatinal Beemerose [Leucite-phonolite].

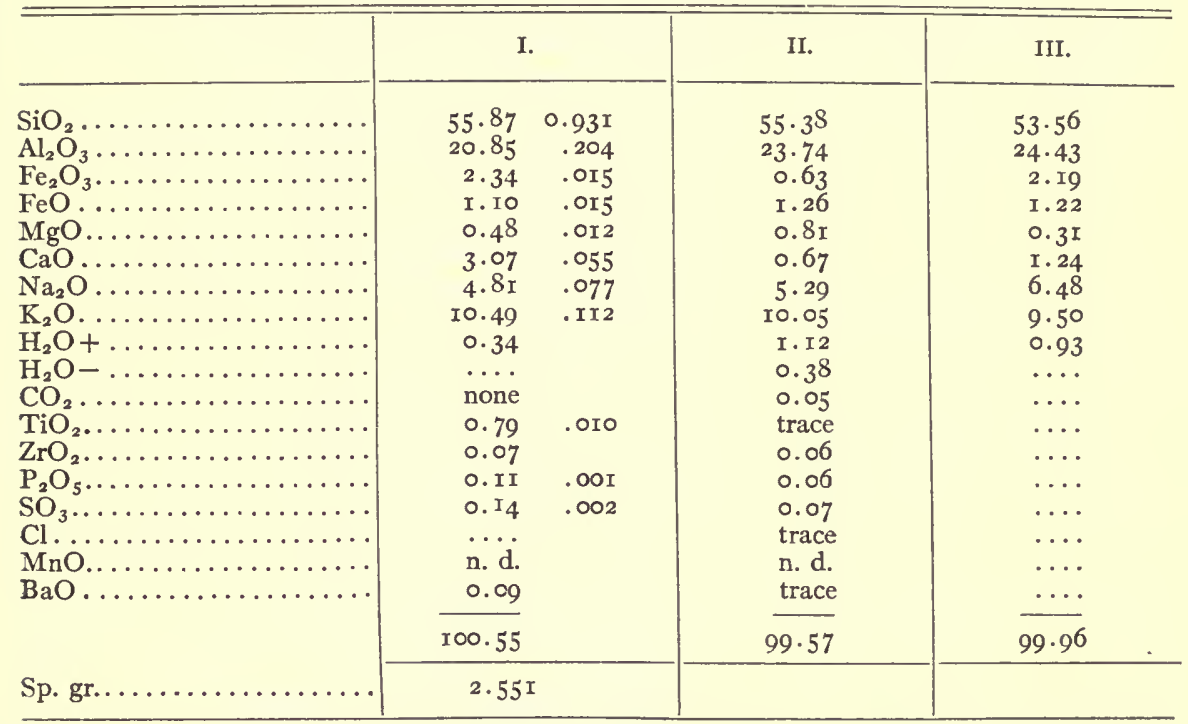

I. Sabatinal beemerose [leucite-phonolite]. Poggio Muratella, Lake Bracciano, Sabatinian District. Washington, analyst. Jour. Geol., V, ז897, p. 49.

II. Grano-beemerose [nephelite-syenite]. Itschan, East Cape, Siberia. Washington, analyst. Am. Jour. Sci., XIII, I902, p. I76.

III. Grano-beemerose [nephelite-syenite]. Beemerville, Sussex County, New Jersey. Eakins, analyst. Iddings, Bull. U. S. Geol. Surv. No. ${ }_{5}$, 1898, p. 2 rr.

Norm of $I$.

Or..............62.27

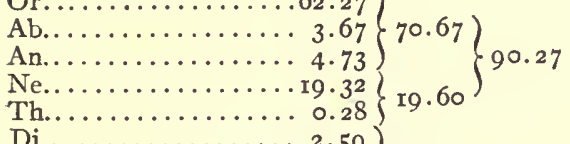

Wo................ 3.02 $\} 5.6 \mathrm{I}$

Ol...................

Mt............ r. 6

Il................. I. 52$\} 4.12$

$\mathrm{Hm} \ldots \ldots \ldots \ldots \ldots \ldots$ I. 44

100.00

Rest.......... $0.6 \mathrm{r}$
Ratios of $I$.
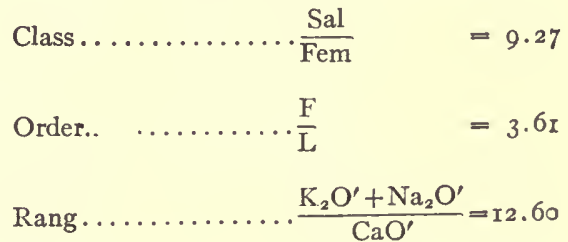

Subrang............ $\frac{\mathrm{K}_{2} \mathrm{O}^{\prime}}{\mathrm{Na}_{2} \mathrm{O}^{\prime}} \quad=\mathrm{I} .45$ 
As regards class, sabatinal beemerose lies toward the dosalanes, but is far from being transitional. In order and rang it is quite close to the center points, though the amount of lime is somewhat high. In the subrang it approaches the dopotassic border, though it can hardly be called transitional.

Analyses of two other types of beemerose are given in II and III. In both of these the mode and texture differ widely from the Italian type. Though they resemble each other in being holocrystalline, coarse-grained, and more or less homometric, they not only belong to different types, but exhibit very distinct modes. Their analyses are of interest in this connection, not only as they represent a subrang the rocks of which are decidedly rare, but still more because these three form another excellent illustration of wide divergence in mode with great similarity in chemical composition. Comparison of the analyses of these three rocks and consideration of the varying modes will repay some study, but would lead us too far astray.

Mode.-The mode was determined by measuring the leucite megaphenocrysts on the surfaces of a large hand specimen and by measuring the microphenocrysts and the constituents of the groundmass at two magnifications. It can not be checked satisfactorily by calculation from the norm, as two feldspars, orthoclase and albite, and the two lenads, leucite and nephelite, are present, and the exact amounts of these last can not be measured, owing to the texture. To distribute the silica, therefore, we would have four unknown quantities and but three equations. The amount of nephelite, and consequently that of orthoclase, as the two were measured together, are but rough approximations, but they can not be far from the truth. The calculated composition of the feldspar is that indicated by the molecules of potash and soda left over after using what were needed for leucite, nephelite, haüyne, and some acmite. The amount of haüyne, calculated as noselite from the $\mathrm{SO}_{3}$, is I.r 3 , so that in this case, as in the preceding, the estimation of this mineral is very satisfactory. The exact amount of ægirite-augite can not be calculated, as its composition is unknown, though an approximation may be arrived at by making assumptions as to its chemical composition. If the acmite present is calculated on the basis of the amount of normative hematite, the total pyroxene would be about ro per cent, which is undoubtedly much too high. The amounts of augite and magnetite as given in the mode are somewhat too high, owing to overlapping, but are probably not far wrong.

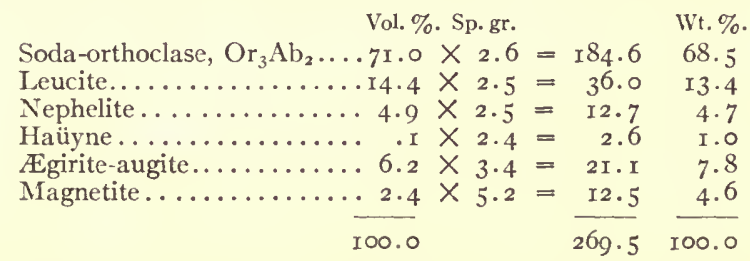

Comparing the mode with the norm, it is clear that the chief and only important points of difference are in the modal presence of leucite, this being accompanied by decrease in the amounts of orthoclase and nephelite as compared with the norm. The type therefore may be described as leucite-salphyro-beemerose. 
Occurrence.-This type is found only in the Sabatinian District, so far as is known with certainty. The most prominent locality is a massive flow on the northwest shore of Lake Bracciano, below Poggio Muratella, the lava being derived, according to Moderni, from the cone of Poggio Tondo to the northwest. The type also forms blocks in bedded tuffs in the railroad cut about $2 \mathrm{~km}$. southeast of Oriolo station, which are probably from the same cone. Another excellent locality is on the north shore of Lake Bracciano, just west of Vicarello, at the end of a large lava stream from the cone of Monte Levo.

A rock which may be provisionally referred to this type occurs near Acquapendente (especially at a quarry at the east gate), north of Lake Bolsena, in the Vulsinian District. No analysis has yet been made of this, and although it is certain that it falls in the same class, order, and rang as beemerose, it is possibly in the dopotassic subrang, which is as yet unrepresented. From the descriptions of Bucca and Klein it is possible that rocks belonging to the same subrang, or that of beemerose and of the same or similar type, occur elsewhere in the district, especially in the northwest, around the Latera Volcano.

Name.-The name of the subrang is derived from the locality, Beemerville, near which a well-known type occurs. That of the type is derived from that of the district where it occurs.

In the prevailing systems of classification these rocks would be called either leucite-trachyte or leucite-phonolite, according to Zirkel, or leucite-phonolite or leucitophyre, according to Rosenbusch, as one does not or does lay stress on the presence of nephelite. In a previous paper I used the name leucite-phonolite in the sense of Zirkel, as the presence of nephelite and haüyne, even in rather small amount, seemed to be of sufficient importance to distinguish these rocks from other similar ones of the region which are free from these lenic minerals.

SABATINAL BEEMEROSE. 1. 6. 1. 3.

Megascopic characters.-Very light gray, compact, porphyritic. Leucite phenocrysts common, not well shaped, from 2 to $10 \mathrm{~mm}$., often yellowish and waxy luster, very few inclusions. Some augite phenocrysts, about $\mathrm{x} \mathrm{mm}$. long, black. Groundmass: light gray, aphanitic. Specific gravity $2.55^{\mathrm{I}}$ at $10^{\circ} \mathrm{C}$.

Microscopic characters.-Holocrystalline, megaporphyritic, dopatic. Phenocrysts: about I2 per cent, leucite, ægirite-augite. Groundmass: about 88 per cent, confused, hypautomorphic granular fabric, soda-orthoclase, leucite, haüyne, nephelite, ægirite-augite, magnetite, apatite, titanite.

Soda-orthoclase, $\mathrm{Or}_{3} \mathrm{Ab}_{2}$. - Phenocrysts: none. Groundmass: about 70 per cent, 0.2 to $0.4 \mathrm{~mm}$., subhedral, stout prisms, arrangement diverse.

Leucite.-Phenocrysts: about Io per cent, 2 to Io mm., subhedral to anhedral, equant to irregular, twinning common, inclusions of augite and groundmass rare. Groundmass: about 5 per cent, 0.05 to 0 . Io mm., anhedral, equant, few inclusions, sometimes altered to pseudoleucite.

Egirite-augite.-Phenocrysts: about 2 per cent, 0.5 to $1.0 \mathrm{~mm}$., subhedral, stout prismatic, olive-green, pleochroic. Groundmass: about 5 per cent, 0.02 to $0.05 \mathrm{~mm}$., anhedral, prismatic, light olive-green.

Nephelite.-Groundmass: about 5 per cent, anhedral, cement about the other minerals of the groundmass. 
Haiiyne.-Groundmass, about I per cent, 0. I to $0.2 \mathrm{~mm}$., subhedral to anhedral, equant to irregular, colorless or blue, dusty inclusions.

Magnetite-Groundmass: about 3 per cent, $0.02 \mathrm{~mm}$., anhedral, equant.

A patite and titanite.-Groundmass: less than I per cent, very small, subhedral, usual forms.

Chemical composition as on p. 47 .

Type specimen from below Poggio Muratella, northwest shore of Lake Bracciano, Sabatinian District.

\section{II-I. 7. 1. 3. Tavolatal Janeirose=Appianose [Leucite-Tephrite, Tavolato Type, Tavolatite].}

Megascopic characters.--Rocks of this type are light gray and very coarsely porphyritic. Large white or very pale-gray leucite phenocrysts are quite abundant. These vary in size from Io to $30 \mathrm{~mm}$., are for the most part euhedral with wellformed crystal planes, though often in fragments, and carry few evident inclusions. Small blue specks of haüyne and fewer small black prisms of augite are numerous, and an occasional yellow grain of garnet is visible. The groundmass is light gray and quite aphanitic.

Microscopic characters. - The large leucite phenocrysts offer few features of special interest in the thin sections. They show the usual twinned structure, and carry only a few inclusions of blue haüyne and less often of augite. The haünnes are sometimes euhedral in cubes and dodecahedra, but more often are "corroded" deeply and irregularly. They are of a rather pale blue color and are often very dusty with the common minute inclusions, which are sometimes arranged in straight lines, parallel to the crystal faces and crossing each other reticulately, and again are irregularly scattered through the crystal and not zonally arranged. The small augite phenocrysts, which form anhedral stout prismoids, are usually of a deep brownish-green, somewhat pleochroic, and evidently contain some of the ægirite molecule.

Small, round, anhedral microphenocrysts of leucite are very abundant in the groundmass, their outlines being rather ill-defined in the surrounding cement. Small microphenocrysts of feldspar are rare, in the form of anhedral, stout prismoids. These are partly of orthoclase and somewhat less frequently of soda-lime feldspar, which varies in composition from labradorite, $\mathrm{Ab}_{\mathrm{I}} \mathrm{An}_{2}$, to anorthite. There are also a few small brown garnets, generally in well-formed crystals, which frequently show a zonal structure, and an occasional small brown biotite table is seen.

The micro-groundmass in which these lie contains many very small, slender feldspar prismoids, with a diverse arrangement, and which are in part orthoclase and to a much less extent labradorite. With these are small prismatic anhedra of the green ægirite-augite. These are cemented by a colorless, feebly doubly refracting substance, which is undoubtedly nephelite. It is noteworthy that magnetite was wholly absent from the specimen analyzed and described. Glass is mentioned by Struever and others as replacing the nephelite base, but none of the specimens which I collected contain it. 
Chemical composition.-For the analysis of tavolatal appianose a whole hand specimen was crushed and sampled, so as to obtain representative material without an undue amount of groundmass. The analysis is remarkable for the very high potash, which is exceeded only by that in some of the analyses of orendose from Wyoming. The analysis by Aichino of the same rock varies widely from mine in many important particulars. It was probably made on unrepresentative material, containing relatively too much groundmass. This, however, would not account for the inverse ratio of the alkalis as compared with $\mathrm{I}$, and as the microscopic examination shows that potash is present in greater amount than the soda (even in the groundmass), it would seem to be possible that the figures for the alkalis in II have been accidentally interchanged, as has happened in other cases. The other discrepancies of note are also difficult to account for, and the analysis can not be regarded as very trustworthy.

Chemical Composition of Tavolatal Janeirose-appianose [Leucite-tephrite, Tavolatite].

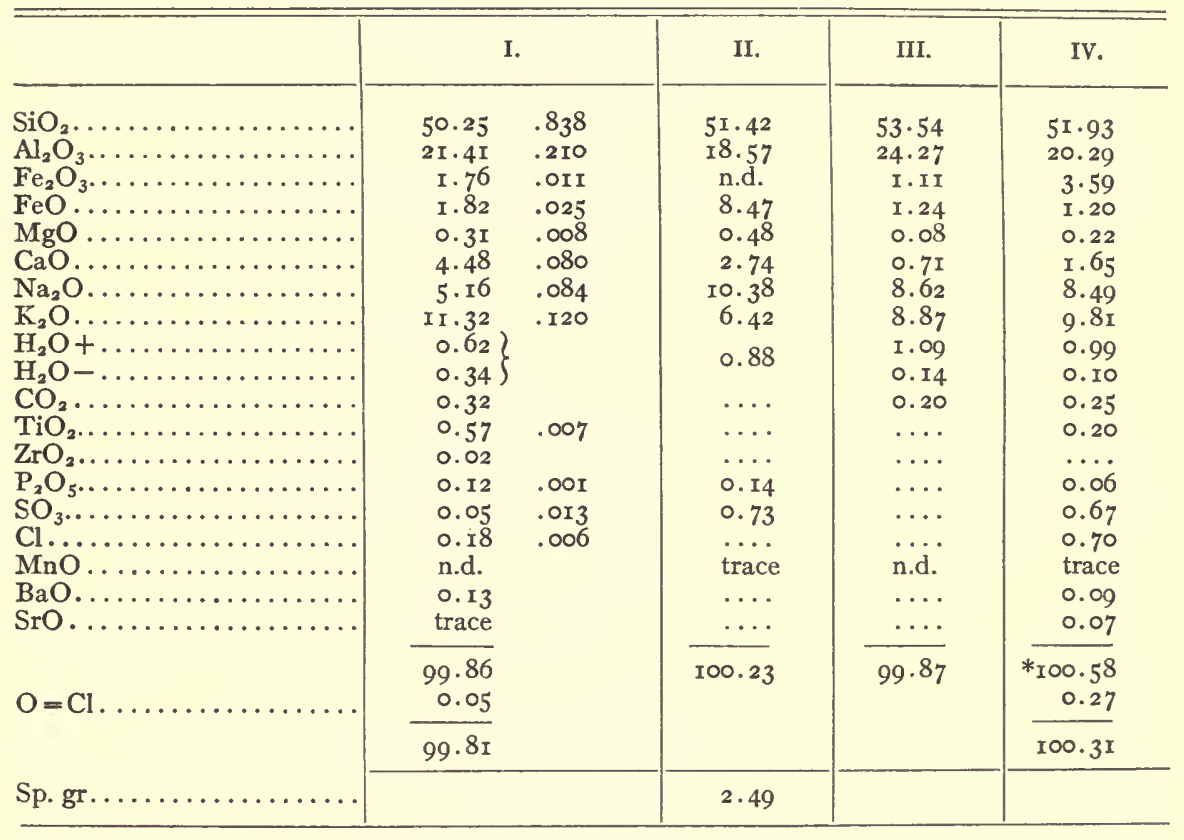

*Includes also $0.27 \mathrm{~F}$ and trace of $\mathrm{Li}_{2} \mathrm{O}$.

I. Tavolatal janeirose-appianose [haüynitic leucite-tephrite]. Osteria di Tavolato, Appian Way, Latian District. Washington, analyst.

II. Tavolatal appianose [haüynitic leucite-tephrite]. Same locality. Aichino, analyst. Sabatini, Mem. Descr. Cart. Geol. Ital., X, Igoo, p. I64.

III. Grano-appianose [foyaite]. J. M. Henry No. 2, near Chamberlain Creck, Magnet Cove, Arkansas. Washington, analyst. Jour. Geol., IX, r9or, p. 667.

IV. Beaveral janeirose [leucite-tinguaite]. Beaver Creek, Bearpaw Mountains, Montana. Stokes, analyst. Weed and Pirsson, Am. Jour. Sci., II, I896, p. 196. 
Norm of $I$.

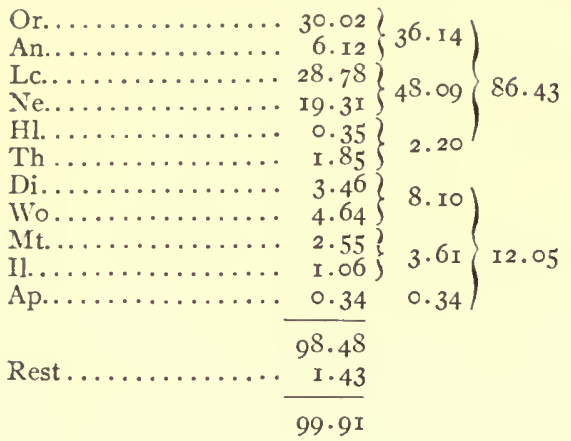

Ratios of $I$.

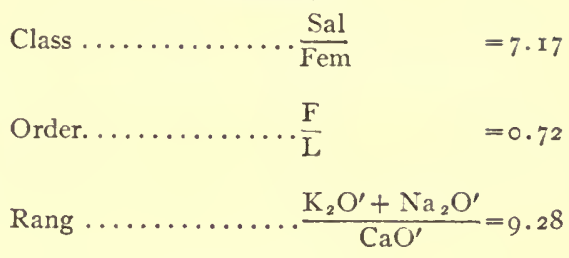

Subrang. ........... $\frac{\mathrm{K}_{2} \mathrm{O}^{\prime}}{\mathrm{Na}_{2} \mathrm{O}^{\prime}} \quad=I .43$

The magmatic position of the tavolatal appianose is distinctly transitional as regards class, the ratio of sal to fem being almost exactly on the border between persalane and dosalane. The magma consequently is a janeirose-appianose. The similarity to an analysis of a typical janeirose rock is shown by comparison of $I$ and IV, the chief divergencies being in the alkalis. It will be seen on reference to the norms of the two that the dosalic position of the latter rock is brought about by the presence of acmite, both normative and modal, while in the Italian rock this mineral does not occur normatively, and only to a subordinate extent modally. As regards order, rang, and subrang, it need only be said that the tavolatal appianose is well within the respective limits of these divisions.

The only other analysis yet known of an appianose rock is one from Magnet Cove, shown in III, which is non-leucitic, the only lenad present being nephelite. As the alkalis show, this latter rock is quite close to the dosodic subrang laugenose.

Mode.-Owing to the small size and confused arrangement of the groundmass constituents and the presence of the ill-defined cement, an exact estimation of the mode by Rosiwal's method was almost impossible, though it was practicable for some of the constituents, as the phenocrysts of leucite, labradorite, haüyne, ægiriteaugite, and melanite. The complexity of the mineral composition also precluded an exact calculation from the norm. By assuming that the composition of the pyroxene was that of the ægirite-augite of Elfdalen, and that those of the haüne and melanite were represented by well-known analyses of these minerals from the Alban Hills, and checking the calculations by the microscopic observations, the following mode was estimated. That it is approximately correct is shown by a comparison of the chemical composition recalculated from this with that obtained by chemical analysis. The agreement is seen to be as satisfactory as could have been expected when dealing with such a complex rock.

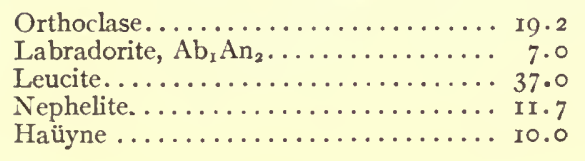

Ægirite-augite .............. I r.5

Melanite .................. 2.0

Biotite .................. 1.3

Apatite.................... 0.3

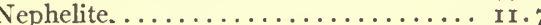

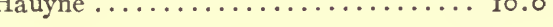




\begin{tabular}{|c|c|c|c|c|c|}
\hline & I. & II. & & I. & II. \\
\hline 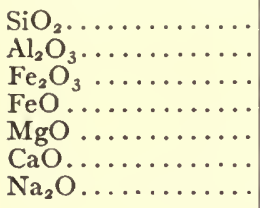 & $\begin{array}{r}5 \mathrm{I} .0 \\
2 \mathrm{I} \cdot 7 \\
2.4 \\
0.7 \\
0.8 \\
4.0 \\
5 \cdot 1\end{array}$ & $\begin{array}{r}50.3 \\
21.4 \\
I .8 \\
1.8 \\
0.3 \\
4.5 \\
5.2\end{array}$ & $\begin{array}{l}\mathrm{K}_{2} \mathrm{O} \ldots \ldots \\
\mathrm{TiO}_{2} \ldots \ldots \\
\mathrm{P}_{2} \mathrm{O}_{5} \ldots \cdots \cdots \\
\mathrm{SO}_{3} \cdots \cdots \\
\mathrm{Cl} \ldots \ldots \\
. \cdots \cdots\end{array}$ & $\begin{array}{r}\text { II. } \\
\text { I. } \\
0.1 \\
\text { I. } \\
0.1 \\
\text { IOO.I }\end{array}$ & $\begin{array}{r}\text { II . } 3 \\
0.6 \\
0.1 \\
\text { I.I } \\
0.2 \\
98.6\end{array}$ \\
\hline
\end{tabular}

I. Calculated from the mode. II. Determined by chemical analysis.

Comparison of this mode with the norm shows that, while the divergencies are considerable, the readjustments affect all of the normative molecules and are well distributed. The readjustments of most moment are the formation of the haüyne from normative nephelite, brought about by the normative thenardite and halite, and the large increase in the amount of leucite, chiefly brought about by the change of some of the normative nephelite to modal albite in the labradorite. Readjustments of subsidiary importance are those involved in the formation of the ægiriteaugite and melanite, the latter being the most striking varietal mineral, as the presence of some modal acmite molecules are to be expected in sodipotassic rocks of this region. Taking all these into consideration, as well as the fact that the phenocrysts are of the lenads leucite and haüyne, we may describe the Tavolato blocks as melanitic haüyne-lenphyro-janeirose-appianose, a rather ungainly nomenclatorial product, which the shorter tavolatal appianose replaces advantageously.

Occurrence.-This type is represented only in the Latian District, and here but sparingly. The best-known locality is that near the Osteria di Tavolato, on the Via Appia Nuova, about $5 \mathrm{~km}$. from Rome, where it is found as blocks in an agglomerate of volcanic material, along with rocks belonging to the types and subrangs which are more common in the district. The provenience of these Tavolato blocks is, as yet, uncertain, although they are undoubtedly derived from the Albano Volcano. Closely similar types have been described by Struever and Sabatini from elsewhere in the district, as near the Lago di Nemi.

Name.-The name of the subrang is derived from that of the old Roman highway, the Via Appia, near which the type occurs. The type adjective is derived from the oldest and best-known locality named above.

In the prevailing classifications this type is constantly called a leucite-tephrite, of the phonolithoid Typus according to Rosenbusch. But the classification of these rocks as tephrites is scarcely justified by the mode described above, by which it is seen that the rock contains only about 7 per cent of plagioclase, but about ig of orthoclase and $\mathbf{1} 2$ of nephelite, and this subordinate position of the lime-soda feldspar is more or less clearly evident in the descriptions published by others. Disregarding this mineral, then, and taking into consideration the very notable amounts of the lenads nephelite and haüyne, the type should be called a haüynitic leucite-phonolite in the sense of Zirkel, or a leucitophyr of Rosenbusch. The remarkable chemical com- 
position of this type, its peculiar mode or mineral composition, the abundance of haüyne, and the very large size of the leucite phenocrysts distinguish it clearly from nearly all other leucite-phonolites, and in the prevailing classifications it would seem to be deserving of a distinct name, for which that of tavolatite might be chosen.

TAVOLATAL JANEIRO SE-APPIANOSE. II-I. 7. 1. 3.

Megascopic characters. - Light gray, compact, highly porphyritic. Leucite phenocrysts numerous, large, to to $30 \mathrm{~mm}$., well crystallized, but often fragmentary, few inclusions. Haüyne phenocrysts numerous but very small, up to I mm., blue. Augite phenocrysts few and small, black. Garnet phenocrysts very rare and small, yellow. Groundmass: light gray, phanerocrystalline, very fine-grained.

Microscopic characters.-Holocrystalline, porphyritic, dopatic. Megaphenocrysts: about 30 per cent, leucite, haüyne, ægirite-augite, garnet. Microphenocrysts: about 55 per cent, leucite, orthoclase, haüyne, labradorite, ægirite-augite, garnet. Microgroundmass, about I5 per cent, nephelite, orthoclase?

Leucite.-Megaphenocrysts: about ${ }_{5}$ per cent, io to $30 \mathrm{~mm}$., euhedral to subhedral, often fragmentary, equant, twinned, inclusions few, of haüyne and augite. Microphenocrysts: about 20 per cent, 0.1 to $0.3 \mathrm{~mm}$, anhedral, equant and irregular, often not well defined, few inclusions.

Orthoclase.-Microphenocrysts, about 20 per cent, 0.05 to $0.50 \mathrm{~mm}$., anhedral to subhedral, stout prismatic, arrangement diverse. Microgroundmass: about 5 per cent possibly present as cement.

Nephelite.-Groundmass: about 12 per cent, interstitial cement.

Haüyne.-Megaphenocrysts: about 8 per cent, 0.5 to $1.0 \mathrm{~mm}$., euhedral and anhedral, equant and irregular, often deeply corroded, usually blue, many dusty inclusions. Microphenocrysts: about 5 per cent, 0.05 to $0.5 \mathrm{~mm}$., same characters as megaphenocrysts except size.

Labradorite, $\mathrm{Ab}_{1} \mathrm{An}_{2}$.-Phenocrysts: about 7 per cent, 0.05 to $0.50 \mathrm{~mm}$., anhedral, stout prismatic, multiple twinning constant.

Egirite-augite.-Megaphenocrysts: about 5 per cent; microphenocrysts: about 6 per cent; 0.05 to $2.0 \mathrm{~mm}$., anhedral to subhedral, stout prismatic, brownish-green, pleochroic.

Garnet.-Phenocrysts: about 2 per cent, 0.2 to $2.0 \mathrm{~mm}$., subhedral, equant, brown, often zonal.

Biotite.-Phenocrysts: about I per cent, subhedral, tabular, brown.

Chemical composition, norm, and mode as above.

Type specimen from Osteria di Tavolato, Via Appia Nuova, Latian District.

\section{4. 3. 3. Sorianai Harzose [Biotite-Latite, Soriano Type].}

The rocks of this type occur in the Roman Region in two distinct forms, the one a compact lava, the other a flow-breccia. Although the two seem, at first sight, to be quite distinct, they may both be considered to be of the same petrographic type, the differences between them being differences of consolidation merely, due to the viscosity of the material and slightly varying accidental conditions during extrusion. For this reason they will be considered together, though the field and microscopic characters of each will be described separately.

Megascopic characters-Lava form: These rocks are very dark, compact and highly porphyritic. Small tabular phenocrysts of feldspar are abundant, making up about one-quarter of the rock volume. With them are many, but less numerous, small, glistening, dark tables of biotite and prisms of pyroxene. These lie 
scattered through a very dark, sometimes almost black, entirely aphanitic groundmass, which may appear hyaline at times.

Breccia form: This form of the type is much lighter and somewhat variable in color, light gray in the freshest specimens, and yellowish to reddish in those which are weathered. The hand specimens usually show a somewhat streaked or schlieric appearance, due to lines and patches of darker and lighter gray, or grays and yellows. In some places these streaks have a generally parallel and horizontal arrangement, with the biotite tables mostly horizontal, simulating a sort of bedded or flow structure. The rocks are quite rough and soft and rather friable when first quarried, but harden on exposure. They are highly porphyritic, containing numerous small white prismoids of feldspar, many small glistening tables of biotite, and some prisms of pyroxene. The aphanitic groundmass is either gray or somewhat yellowish or reddish.

Microscopic characters - Lava form: The feldspar phenocrysts are seen in thin section to be of both orthoclase and labradorite, the former being more numerous. They are usually twinned and do not carry many inclusions. There are few small anhedral or fragmentary prismoids of a colorless or very pale-gray pryoxene, some of which is augite, but the greater part of which is hypersthene. Biotite tables are abundant, more so than would appear to be the case from the megascopic examination. They are from $\mathrm{I}$ to $2 \mathrm{~mm}$. across, and are almost uniformly altered, the larger ones on the edges and the smaller ones throughout, to a dark, finely granular aggregate. The groundmass in which these lie, forming about 70 per cent of the rock, is a colorless glass, thickly sprinkled with very minute prismoids of pyroxene, apparently hypersthene, some small feldspar laths, but no magnetite grains. With low powers this glass and its crystals show evidence of flow around the phenocrysts. No quartz was seen in any of my specimens.

Breccia form: The feldspar phenocrysts here also are of both orthoclase and labradorite, the former more abundant, but they are for the most part angular and decidedly fragmentary, few showing well-defined prismatic or tabular shapes. There are the same phenocrysts of colorless augite and hypersthene, but these are also much more broken than in the preceding form. The numerous biotite tables are similar to those in the lava and have suffered much less deformation and rupture. The cement between these is either a dusty, rather indeterminate but evidently vitreous mass, or a colorless glass which contains many minute fragments and anhedra of the minerals mentioned above. In either case the cement exhibits a well-marked flow structure around the larger crystal fragments.

There has been much discussion as to the character of this rock, called locally "peperino," opinions being divided as to whether it is a tuff or a lava. In a previous paper I considered it a tuff, though somewhat doubtfully. But examination of the specimens collected since the earlier publication would show that these rocks are, for the most part at least, not tuffs, but lava-breccias or flow-breccias, that is, lavas which had partially crystallized and solidified during eruption, but which the still moving, very viscous flow shattered and brecciated, this fluid portion forming on 
solidification the glassy cement. This view of their origin is that held by Doctor Cross and Professor Iddings, who very kindly examined my specimens and remarked on their similarity to the numerous flow-breccias of the Western States, with which they are very familiar. This explanation of their texture agrees with the observed occurrences in the field, where they appear for the most part to be flows rather than bedded tuffs, and yet have left unaltered the subjacent rocks, and it harmonizes the divergent views as to their origin.

Chemical composition.-A specimen of the breccia variant was chosen for analysis, rather than one of the lava, as it is locally far the more important. The analysis calls for no special comment, except that it indicates that the rock is quite fresh. The magmatic position of the rock is not very close to the center point of any of the divisions, as is evident from the ratios given, except in the case of the subrang, where the alkalis are almost equal. The analysis by Ricciardi of a closely similar rock, though transitional between the typical peperino and that with large feldspars according to Mercalli, is given for comparison, and the general resemblance is rather close. It must be remarked, however, that the figures in Ricciardi's analyses are often open to doubt as to their accuracy, in many cases demonstrably widely inaccurate, so that the analysis is of little value. For this reason the norm was not calculated.

Chemical Compositon of Sorianal Harzose [Biotite-latite].

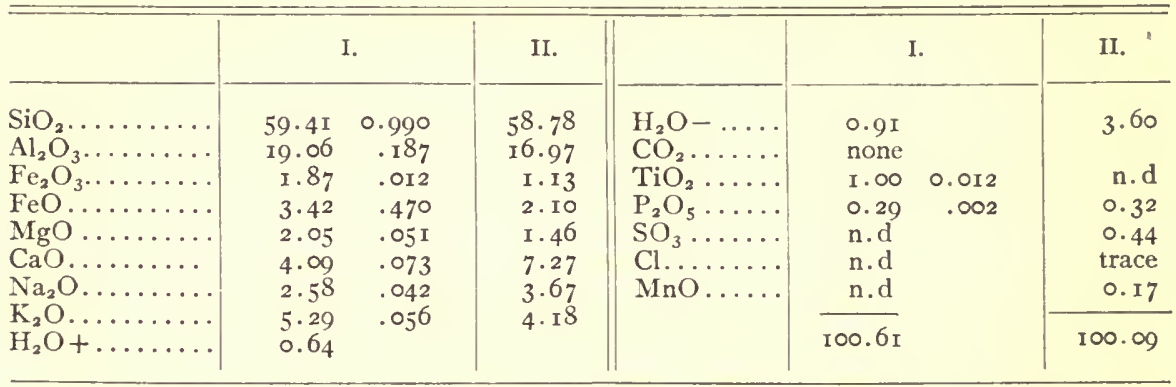

I. Sorianal harzose breccia [biotite-latite]. La Cava, near Viterbo, Ciminian District. H. S. Washington, analyst.

II. Peperino. Bagnaia, near Viterbo, Ciminian District. L. Ricciardi, analyst. Cf. Mercalli, Mem. Acc. Linc., XX, 1903, p. I2.

Norm of $I$.

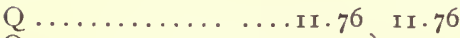

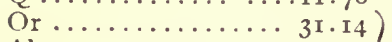

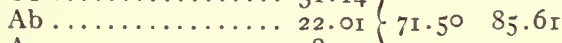

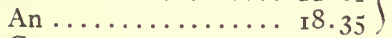

C............. $2.35 \quad 2.35$

Hy............ 8. 84 8.14

$\left.\begin{array}{lll}\mathrm{Mt} \ldots \ldots \ldots \ldots \ldots \ldots \ldots & 2.7^{8} \\ \mathrm{Il} \ldots \ldots \ldots \ldots \ldots \ldots & \mathrm{I} . \mathrm{S}_{2}\end{array}\right\} 4.60 \mathrm{I} 3.4 \mathrm{I}$

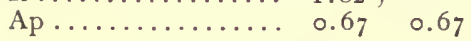

Rest......... $\frac{99.02}{1.55}$
Ratios of $I$.

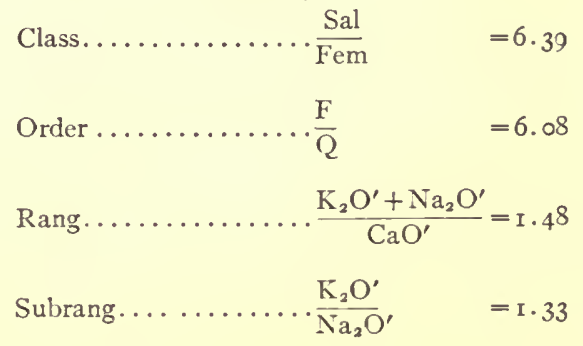


Mode.-As the mode is indeterminate, through the presence of abundant glass, discussion of it is uncalled for. Were the rock holocrystalline, however, with the same minerals present as shown in this form, its mode would probably be roughly something like this:

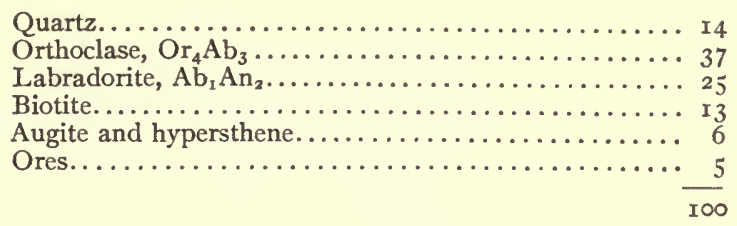

Occurrence.-Sorianal harzose was found only in the Ciminian District, around the Cimino Volcano, where the lava form occurs as flows and as blocks in the tuffs at many places. Among the localities where I obtained typical specimens may be mentioned flows from Monte Ciliano, along the highway northwest of Soriano, and at Le Piaggie, about $3 \mathrm{~km}$. southwest of Soriano, as well as in the ravine near Bagnaia, where it occurs as blocks (sometimes reddened through weathering) in the lower tuffs.

The breccia form of sorianal harzose (peperino) is met with in abundance around the Cimino Volcano, especially on the west, north, and northeast, and it forms much of the lower slopes of the hills. So abundant is it that enumeration of special localities is superfluous, and the only ones that need be named are the quarry of L. Mercati, at La Cava, near Viterbo, from which the analyzed specimen was obtained, and the vicinity of Bagnaia.

Name.-The derivation of the subrang name has been discussed elsewhere. That of the type is derived from the town of Soriano, near which it is very abundant.

In prevailing classifications there has been considerable diversity as to the name of these rocks. The lava form has been called a trachyte by vom Rath, an andesitic trachyte or trachy-andesite by Mercalli, and a mica-andesite by Deecke. Consideration of the mode, which shows almost equal amounts of alkali and sodalime feldspar, would seem to render Ransome's term "latite" suitable, especially as the free silica has not crystallized out as quartz. As the prominent alferric mineral is biotite it may be classed, then, as biotite-latite.

The diversity of opinion as to the origin of the breccia form has already been touched on. The rocks known locally as peperino, and called by Brocchi necrolite, on account of their use by the Etruscans for sarcophagi, embrace two distinct types. The one is the péperite des hauteurs of Sabatini and the trachite-andesitico d grossi sanidini of Mercalli, which is the earliest product of eruption and forms the nucleus of the Cimino Volcano. This peperino apparently belongs to the subrang vulsinose and is sometimes a lava, sometimes a flow-breccia, and sometimes a tuff. The other is the péperite typique of Sabatini and the trachite-andesitico à piccoli felspati of Mercalli, which overlies the other, and which is apparently earlier than the flows of ciminose to be described presently. This peperino is the breccia form of sorianal harzose, and might be called in the prevailing nomenclature a biotite-latite breccia. 


\section{SORIANAL HARZOSE.*}

Megascopic characters.-Dark gray, compact, highly porphyritic. Feldspar phenocrysts abundant, 2 to $5 \mathrm{~mm}$., tabular, colorless or white. Phenocrysts of biotite common, small, glistening, dark-brown tables. Phenocrysts of pyroxene rare, small prismatic, black. Groundmass dark gray, aphanitic, sometimes vitreous looking.

Microscopic characters.-Hyalocrystalline, megaporphyritic, mediophyric. Phenocrysts: about 40 per cent, orthoclase, labradorite, biotite, hypersthene, augite. Groundmass: about 60 per cent, glass with microlites of hypersthene and feldspar. Flow structure visible.

Orthoclase, $\mathrm{Or}_{4} \mathrm{Ab}_{3}$ ?.-Phenocrysts: about 20 per cent, 2 to $5 \mathrm{~mm}$., tabular or stout prismatic, subhedral to euhedral, Carlsbad twinning. Groundmass: small indeterminable amount, 0.01 to $0.03 \mathrm{~mm}$., prismatic, scattered in flow structure through the glass base.

Labradorite, $\mathrm{Ab}_{1} \mathrm{An}_{2}$.-Phenocrysts: about 7 per cent. 2 to $5 \mathrm{~mm}$., euhedral to subhedral, tabular or stout prismatic, multiply twinned.

Biotite.-Phenocrysts: about ro per cent, 0.05 to $0.5 \mathrm{~mm}$., subhedral, thin tabular, brown, much altered.

Hypersthene.-Phenocrysts: about 4 per cent, O. I to r.o mm., subhedral to anhedral, prismatic to irregular, often fragmentary, colorless. Groundmass: very small, indeterminable amount, 0.01 to $0.03 \mathrm{~mm}$., anhedral prismatic, scattered with flow structure through the glass base.

Augite.-Phenocrysts: about 2 per cent, o.r to r.o mm., subhedral to anhedral, stout prismatic or fragmentary, colorless. Groundmass: augite may be present in very small amount, as minute prisms along with hypersthene in the glass base.

Glass.-Nearly 60 per cent, colorless, often dusty, contains the small microlites described above, flow structure common.

Chemical composition and norm as on p. 56. Mode indeterminate.

Type specimens from Monte Ciliano, Soriano Volcano, Ciminian District. Type specimen of breccia form from La Cava, near Viterbo, Ciminian District.

\section{I-II. 5. 2. 2. Arsal Vulsinose=Ciminose [Vulsinite, Arso Type].}

Megascopic characters.-These rocks are light gray when fresh, but weather to reddish tones, especially in the groundmass. They are decidedly porphyritic, the phenocrysts being quite large and making up rather over one-eighth of the rock mass. The great majority of these, as well as the largest, are of feldspar, which are mostly tabular parallel to $b$ (ого) and from 5 to ro $\mathrm{mm}$. long. There are also few small, black, prismatic phenocrysts of augite, and still more rare small tables of biotite. The light-gray groundmass is clearly phanerocrystalline and fine-grained.

Microscopic characters. - In thin section the phenocrysts of alkali feldspar are seen to be more common than those of the lime-soda feldspar. The former do not show usually the common characteristics of soda-orthoclase; though the analysis of the rock indicates that they are quite sodic, while the latter give extinction angles corresponding to an average composition of $\mathrm{Ab}_{\mathrm{r}} \mathrm{An}_{2}$. Carlsbad twinning is common among the former and the usual multiple twinning among the latter. The feldspars carry few inclusions, mostly of augite and glass, and the orthoclase phenocrysts also inclose occasionally small inclusions of labradorite. The augite phenocrysts are subhedral to anhedral, in stout prisms or fragmentary, of the usual pale gray, sometimes with a slightly greenish tinge, though never pleochroic. The thin tables of biotite are light brown and for the most part altered at the edges to the common aggregate.

* This description applies to the lava form of the type, as the breccia form was not readily measured, and its brecciated condition also does not make a formal description necessary. 
The groundmass is composed in great part of small prisms of feldspar, both of orthoclase and labradorite, the quantity of the former exceeding by several times that of the latter. The arrangement of these laths is subparallel, giving rise to a well-marked trachytic fabric. There are scattered through the groundmass small prismoidal anhedra of colorless augite and some small anhedral grains of magnetite. Between the feldspar laths is a little nephelite cement. This is difficult to detect, but one or two crystal forms were seen, and its presence was verified by treatment of the rock powder with very dilute acid which furnished some gelatinous silica.

Chemical composition.-The only analysis made of this type was published some years ago and is presented below in more complete form, determinations of $\mathrm{TiO}_{2}$ and $\mathrm{P}_{2} \mathrm{O}_{5}$ having been made recently. With it is given for comparison an analysis of the bolsenal vulsinose [vulsinite] from Bolsena.

Chemical Composition of Arsal Vulsinose-ciminose [Vulsinite].

\begin{tabular}{|c|c|c|c|c|c|c|}
\hline & & & II. & & I. & II. \\
\hline \multirow[t]{2}{*}{$\begin{array}{l}\mathrm{SiO}_{2} \ldots \ldots \\
\mathrm{Al}_{2} \mathrm{O}_{3} \ldots \ldots \\
\mathrm{Fe}_{2} \mathrm{O}_{3} \ldots \ldots \\
\mathrm{FeO} \ldots \ldots \\
\mathrm{MgO} \ldots \ldots \\
\mathrm{MaO} \ldots \ldots \\
\mathrm{Na}_{2} \mathrm{O} \ldots \ldots \ldots \\
\mathrm{K}_{2} \mathrm{O} \ldots \ldots \ldots\end{array}$} & \multirow[t]{2}{*}{$\begin{array}{r}57 \cdot 3 \\
19.0 \\
2.2 \\
2.3 \\
1.6 \\
3.8 \\
3.2 \\
9.1\end{array}$} & \multirow[t]{2}{*}{$\begin{array}{l}0.956 \\
.187 \\
.014 \\
.033 \\
.040 \\
.068 \\
.052 \\
.097\end{array}$} & \multirow[t]{2}{*}{$\begin{array}{r}58.08 \\
\text { I9.1I } \\
3.55 \\
1.00 \\
1.05 \\
3.76 \\
2.84 \\
8.86\end{array}$} & $\begin{array}{l}\mathrm{H}_{2} \mathrm{O}+\ldots \\
\mathrm{H}_{2} \mathrm{O}-\ldots \\
\mathrm{CO}_{2} \ldots \ldots \\
\mathrm{TiO}_{2} \ldots \ldots \\
\mathrm{P}_{2} \mathrm{O}_{5} \ldots \ldots \\
\mathrm{MnO} \ldots \ldots\end{array}$ & $\begin{array}{cr}0.57 & \\
\text { none } & \\
0.6 \mathrm{r} & 0.008 \\
0.17 & .00 \mathrm{r} \\
\mathrm{n.d} . & \\
\mathrm{r} 00.09 & \end{array}$ & $\begin{array}{l}0.54 \\
\text { o. I I } \\
\text { none } \\
0.82 \\
\text { o. } 20 \\
\text { n.d. }\end{array}$ \\
\hline & & & & Sp. gr...... & $2.6 \mathrm{II}$ at $\mathrm{II}^{\circ}$ & 2.534 at $25^{\circ}$ \\
\hline
\end{tabular}

I. Arsal vulsinose-ciminose [vulsinite]. Near Vetralla, Monte Vico, Ciminian District. Washington, analyst. Jour. Geol., IV, I896, p. 849.

II. Bolsenal vulsinose [vulsinite]. Bolsena, Vulsinian District.

Norm of $I$.

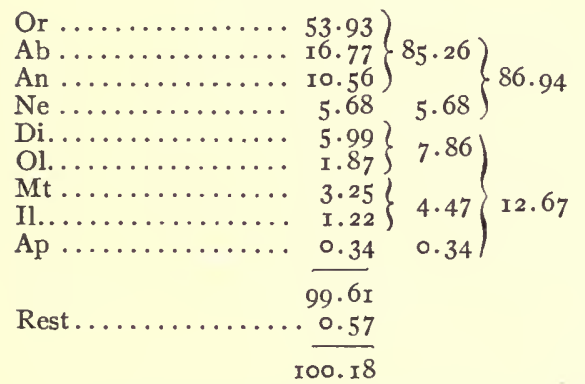

Ratios of $I$.

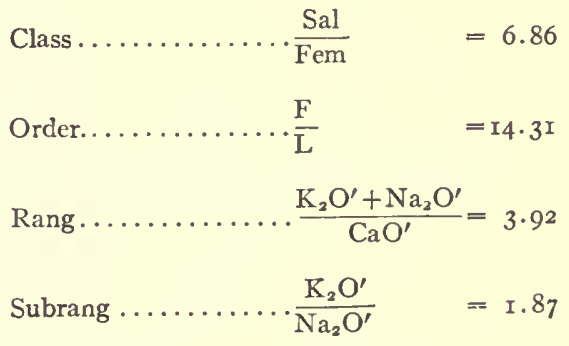

From the figures given above it is clear that this type falls well within the perfelic order, the domalkalic rang, and the dopotassic subrang. On the other hand, it is almost exactly on the border line of the persalane class, where it was formerly* considered to belong. The change in its position is due to the recent determination of $\mathrm{TiO}_{2}$ and $\mathrm{P}_{2} \mathrm{O}_{5}$, which were not reported in the original analysis, and which just

* H. S. Washington, Prof. Paper U. S. Geol. Surv. No. 14, 1903, pp. 198. 199. 
add sufficiently to the femic minerals to carry the rock across the line. This is one of several instances of the same kind which occurred in the present investigation.

This transitional character is also shown by the very close correspondence between the analysis of the ciminose and that of the bolsenal vulsinose given in II. The difference in position is due partly to the slightly higher $\mathrm{FeO}$ and $\mathrm{MgO}$ of II, as well as to its lower silica and higher alkalis. The two former involved the presence of an absolutely greater amount of normative femic minerals, while the two latter necessitated the formation of a considerable amount of nephelite from some of the soda, and thus reduced notably the relative amount of salic minerals.

While the effect of such a shifting of the classificatory position through the influence of very small amounts of minor chemical constituents may seem to be a serious defect in the system of classification, it is in fact not so. For rocks whose position can be thus changed are transitional in character, and in the nomenclature the change is simply one corresponding to the present case, from ciminose-vulsinose to vulsinose-ciminose, and it is a matter of very slight moment in which of the two contiguous divisions the rocks strictly belong.

In the present case it is quite certain that some of the rocks of the region, which will be mentioned later, fall in vulsinose rather than in ciminose, so that they belong to ciminose-vulsinose, or are even possibly so far from the border as to be well within vulsinose itself and not properly transitional. But no analyses of these were made and it was not thought advisable or sufficiently important to erect these at present into distinct types.

Mode.-The calculation of the mode from the norm is comparatively simple. For the augite the composition of that from Ticchiena ( $c f$. p. I34) was assumed, for the small amount of biotite, a mixture in equal parts of leucite and olivine. After assigning sufficient $\mathrm{Na}_{2} \mathrm{O}$ to form albite in the proportion toward the anorthite demanded by the average composition $A_{1} \mathrm{An}_{2}$, the rest was distributed between albite (which enters into the alkali-feldspar) and nephelite, as there was insufficient silica to form the polysilicate molecule with all of it. In determining the mode by the microscope it was found to be impossible to distinguish accurately between the small laths of orthoclase and labradorite, as well as between these and the interstitial nephelite, so that the total amount of these is given.

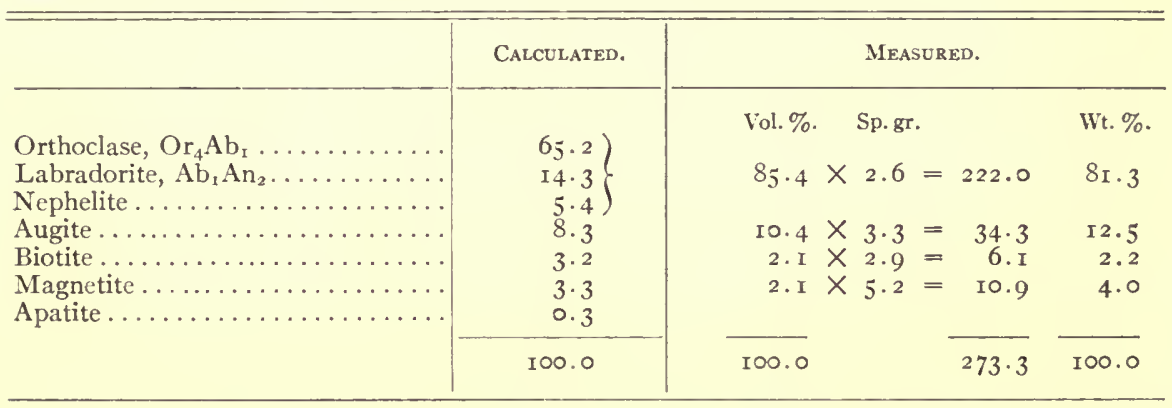

It is seen that the two methods yield very concordant results in this case, the error due to overlapping not being serious. Of the two the calculated mode must 
be regarded as the more reliable, both on the score of freedom from this error and on that of completeness.

Compared with the norm the only divergence of note is that involved in the formation of biotite, which takes up the normative olivine (used as the basis for calculating the biotite) and a little of the orthoclase, as well as the transfer of a very small portion of the normative anorthite and magnetite to form the augite. But these readjustments are of slight importance and their effect is negligible, so that the mode may be considered normative and the rock may be described as normative salphyro-vulsinose-ciminose.

Occurrence.-Typical arsal vulsinose-ciminose is met with especially in the Ciminian District, to the west and southwest of Monte Vico, where it forms extensive flows. The most prominent localities are in the neighborhood of Vetralla and San Giovanni di Bieda, where it is quarried extensively. It is also probable that the type occurs in the northern part of the Vulsinian District and possibly in the Auruncan, but of this there can be no certainty in the absence of specimens and the meagerness of the published descriptions.

Rocks which belong rather to ciminose-vulsinose or to vulsinose, and of this type, are abundant about the Cimino Volcano in the Ciminian District, as at Monte Pallanzana and Monte Valentino, where they form sometimes lava flows, sometimes flow-breccias, and again tuffs. These are the pépérite des hauteurs of Sabatini and the trachite-andesitico à grossi sanidini of Mercalli, already mentioned in connection with sorianal harzose. In these rocks the orthoclase phenocrysts sometimes attain a large size, up to $5 \mathrm{~cm}$. in length. The flow from the Vico Volcano at Massa di San Sisto, southwest of Viterbo, in the Ciminian District, and flows near San Lorenzo in the northern part of the Vulsinian District, also seem to belong in vulsinose rather than in ciminose. As the specimens of these were not very fresh no analyses of them were made.

Name.-The subrang name, ciminose, like the older ciminite, is derived from that of the Ciminian District in which this magma is very common. The type name, arsal, is derived from the flow of L'Arso, on the island of Ischia, as the mode and texture and the habit of the rocks described above much resemble those of the arsal monzonose from the Campanian locality. At the same time, it must be said that the Arso rock differs from those from the Ciminian and Vulsinian Districts in the greater conspicuousness of the feldspar phenocrysts as well as in the presence of accessory olivine phenocrysts. On this account it might be well to distinguish between them and erect two types instead of one, restricting the term "arsal" to rocks identical with the Arso lava and calling those with less conspicuous feldspars and with very small amounts of biotite and no olivine, vetrallal ciminose, vulsinose, or monzonose, as the case may be. But it would seem unwise at the present time to increase the already large number of types described here, and the recognition of such rather unimportant differences may well be left to the future if it be then deemed advisable.

As regards the position of the type in the prevailing systems of classification, the remarks in connection with bolsenal vulsinose (p. 33) will apply here. Placed 
generally in the trachytes, they are distinguished from the most typical of these by the abundance of labradorite and by their chemical composition, on account of which the name of vulsinite has been bestowed on rocks of this type. To distinguish them from the vulsinites which belong to the type of bolsenal vulsinose, with the much smaller and less abundant phenocrysts, the present rocks may be referred to the Arso type, while the others are of the Bolsena type.

ARSAL VULSINOSE=CIMINOSE. I-II. 5, 2.2.

Megascopic characters.-Light gray, compact, rough, porphyritic. Feldspar phenocrysts rather numerous, large, tabular, colorless. Augite phenocrysts rare, very small, prismatic, black. Biotite phenocrysts very rare, thin tabular, brown. Groundmass: very light gray, phanerocrystalline, very fine-grained.

Specific gravity $2.61 \mathrm{I}$ at $\mathrm{x} \mathrm{I}^{\circ} \mathrm{C}$.

Microscopic characters.-Holocrystalline, megaphyric, dopatic. Phenocrysts: about 20 per cent, orthoclase, labradorite, augite, biotite. Groundmass: about 80 per cent, orthoclase, labradorite, augite, magnetite, nephelite. Fabric trachytic.

Orthoclase.-Phenocrysts: about xo per cent, 5 to xo $\mathrm{mm}$. long, subhedral, tabular, Carlsbad twinning common, inclusions few, of augite and labradorite. Groundmass: about $5^{\circ}$ per cent, 0.05 to $0.20 \mathrm{~mm}$., anhedral, stout prismatic and irregular equant, arrangement subparallel.

Labradorite, $\mathrm{Ab}_{\mathrm{r}} \mathrm{An}_{2}$.-Phenocrysts: about 5 per cent, 3 to $7 \mathrm{~mm}$., subhedral, tabular, much twinned, inclusions few, of augite and magnetite. Groundmass: about ro per cent, 0.05 to $0.20 \mathrm{~mm}$., anhedral, stout prismatic, arrangement subparallel.

Augite.-Phenocrysts: about 4 per cent, 0.5 to $2.0 \mathrm{~mm}$., anhedral, stout prismatic and fragmentary, pale greenish-gray, non-pleochroic. Groundmass: about 5 per cent, 0.02 to $0.06 \mathrm{~mm}$., anhedral, prismatic and equant, colorless or very pale-greenish.

Nephelite.-Groundmass: about 5 per cent, rarely subhedral, mostly anhedral, interstitial between the groundmass feldspar laths.

Biotite.-Phenocrysts: about 3 per cent, 0.5 to $2.0 \mathrm{~mm}$., subhedral, thin tabular, light brown, somewhat altered at the edges.

Magnetite.-Groundmass: about 3 per cent, $0.0 x$ to $0.05 \mathrm{~mm}$., anhedral, equant.

A patite.-Groundmass: about 0.5 per cent, subhedral, prismatic.

Chemical composition, norm, and mode as above.

Type specimen from near Vetralla, Ciminian District.

\section{5. 2. 2. Fiescolal Ciminose [Ciminite, Fiescoli Type].}

Megascopic characters. - This type is related texturally to the arsal ciminose, just as is the bolsenal vulsinose to arsal vulsinose, the difference consisting in the size and number of the feldspar phenocrysts. It differs also modally from the arsal type in the presence of olivine instead of biotite, though this is of comparative unimportance.

The rocks are rather light to rather dark gray, and in the hand specimen show but few and small phenocrysts of feldspar, which are tabular and not very conspicuous. There are also small phenocrysts of black augite and of yellow olivine, but these are not very numerous. The gray groundmass is quite aphanitic, and most of the specimens are compact, though a few are somewhat vesicular.

Microscopic characters. - The not very abundant phenocrysts of feldspar are seen in the thin section to be of both orthoclase and of a labradorite of about the composition $\mathrm{Ab}_{\mathrm{I}} \mathrm{An}_{2}$. They are usually tabular, sometimes prismatic, and often 
show some crystal planes, or are subhedral. Twinning is common, but is not very marked, and in most specimens the phenocrysts of both feldspars are about equal in amount. Small, subhedral, often fragmentary phenocrysts of augite are rather more abundant, and are almost wholly colorless, only the larger ones showing a faint greenish tinge. The somewhat less numerous olivine phenocrysts are likewise small and subhedral, most of them having the customary crystal planes. They are much less fractured than the augites and occasionally are euhedral. In thin section they are colorless, but often have a thin outer border of yellow or brown substance, which is probably iddingsite.

The groundmass is typically holocrystalline and the fabric a felted one, due to the diverse arrangement of the feldspar laths. It is made up in great part of very small laths of feldspar, those of orthoclase more numerous than those of labradorite, with small prismoids of augite and grains of magnetite. These are scattered without definite arrangement, giving rise to the felted fabric, through a colorless cement, which usually shows somewhat faint birefringence and is referred to orthoclase. In a few specimens this is replaced by a colorless glass, the amount of which is always negligible, and it is often a matter of difficulty to decide with finality on the holocrystalline character of such groundmasses. In rare cases, as in a flow south of Soriano, the feldspathic cement presents an ill-defined poikilitic texture, irregular and vaguely bounded areas extinguishing simultaneously.

Chemical composition.--Of fiescolal ciminose two analyses are available, both of which have been published previously. As given below they include recent determinations of $\mathrm{P}_{2} \mathrm{O}_{5}$ and also a redetermination of $\mathrm{TiO}_{2}$ in $\mathrm{I}$, with proper corrections of the figures for $\mathrm{Al}_{2} \mathrm{O}_{3}$. It must be noted that the original analysis of this type* was incorrect as regards alumina and magnesia, as was pointed out in a later publication, $\uparrow$ and is therefore to be rejected and replaced by that given here.

Chemical Composition of Fiescolal Ciminose [Ciminite].

\begin{tabular}{|c|c|c|c|c|c|c|c|c|c|}
\hline \multirow{9}{*}{$\begin{array}{l}\mathrm{SiO}_{2} \ldots \ldots \ldots \\
\mathrm{Al}_{2} \mathrm{O}_{3} \ldots \ldots \\
\mathrm{Fe}_{2} \mathrm{O}_{3} \ldots \ldots \\
\mathrm{FeO} \ldots \ldots \\
\mathrm{MgO} \ldots \ldots \\
\mathrm{CaO} \ldots \ldots \\
\mathrm{Na}_{2} \mathrm{O} \ldots \ldots \\
\mathrm{K}_{2} \mathrm{O} \ldots \ldots \\
\mathrm{H}_{2} \mathrm{O}+\ldots \ldots \\
\mathrm{H}_{2} \mathrm{O}-\ldots \ldots\end{array}$} & \multicolumn{2}{|l|}{ I. } & \multicolumn{2}{|c|}{ II. } & & \multicolumn{2}{|c|}{ I. } & \multicolumn{2}{|c|}{ II. } \\
\hline & $55 \cdot 46$ & 0.924 & $57 \cdot 3 \mathrm{I}$ & 0.955 & $\mathrm{CO}_{2} \ldots \ldots$ & none & & none & \\
\hline & 14.47 & .142 & I 4.4 I & .141 & $\mathrm{TiO}_{2} \ldots$ & 0.53 & 0.007 & 0.40 & 0.005 \\
\hline & I. 34 & .008 & I. $2 \mathrm{I}$ & .008 & $\mathrm{P}_{2} \mathrm{O}_{5} \ldots$ & 0.36 & .003 & 0.30 & .002 \\
\hline & $4 \cdot 50$ & .062 & $4 \cdot 37$ & $.06 \mathrm{r}$ & $\mathrm{MnO} \ldots$ & n.d. & & n.d. & \\
\hline & 7.90 & . I98 & 7.80 & . I95 & $\mathrm{BaO} \ldots$ & $\ldots$ & & none & \\
\hline & 6.69 & . I I9 & 6.90 & .123 & & $I 00.2 I$ & & $100.6 \mathrm{I}$ & \\
\hline & r. 79 & .029 & $x \cdot 35$ & .022 & & & & & \\
\hline & $\left.\begin{array}{l}6.63 \\
0.23 \\
0.15\end{array}\right\}$ & $.07 I$ & $\begin{array}{l}6.3^{8} \\
0.18\end{array}$ & .068 & Sp. gr... & 2.70 & at $10^{\circ}$ & & \\
\hline
\end{tabular}

I. Fiescolal ciminose [ciminite]. Fontana Fiescoli, Cimino Volcano, Ciminian District. Washington, analyst. Am. Jour. Sci., IX, rgoo, p. 44.

II. Fiescolal ciminose [ciminite]. La Colonetta, Cimino Volcano, Ciminian District. Washington, analyst. Am. Jour. Sci., IX, I900, p. 44.

* Jour. Geol., IV, 1896, p. 837 .

†Am. Jour. Sci., IX, x900, p. 45. 


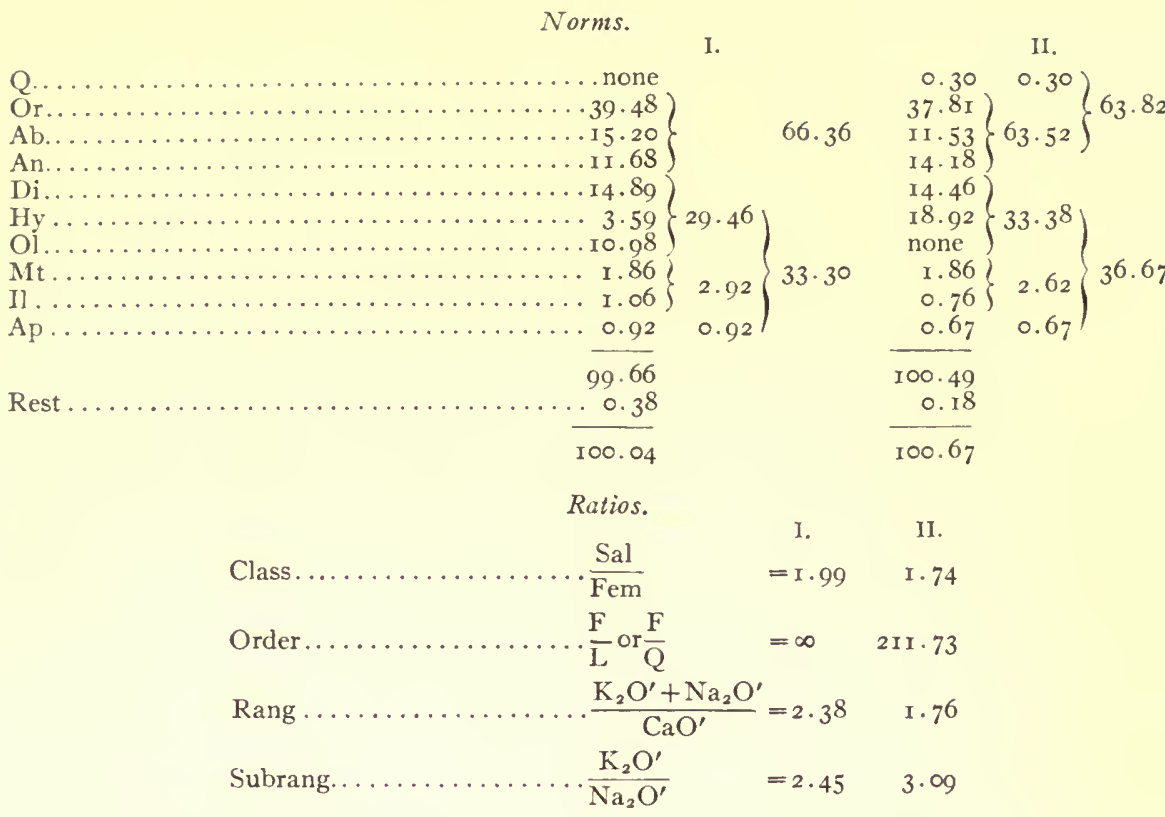

The very close similarity of the two analyses is striking, all the respective figures being almost close enough to be satisfactory duplicates, except in the case of silica, which is higher by 2 per cent in II than in I. In this connection it must be said that the specimen of this rock differs from the other in containing a very small amount of glass, instead of being holocrystalline as is the rock from Fontana di Fiescoli. Corresponding to this chemical difference the norm of II shows not only none of the abundant olivine of $\mathrm{I}$, but hypersthene in its stead and even a trifling excess of silica which appears as normative quartz.

As regards the classificatory positions of the rocks little need be said. They are much alike and fall well within the boundaries of the several divisions, except that II is rather close to the border of salfemane and might strictly be regarded as transitional, that is, belonging to the magma prowersose-ciminose, though this refinement seems to be scarcely advisable. This difference in position is, of course, connected with the presence of hypersthene in the norm of II rather than olivine, and is a consequence of its higher silica.

Mode.-As one of the rocks analyzed is holocrystalline and the other contains a small amount of glass, and as their norms also differ somewhat, the modes of the two were determined separately. On account of the very fine-grained character of the groundmass and its felted texture, the mode could not be estimated in its entirety by Rosiwal's method, though the amounts of the phenocrysts were easily ascertained.

In calculating the mode of the Fiescoli rock few readjustments were needed. The normative amount of olivine was taken as the modal, as this agreed with that meas- 
ured in thin section. The small amount of normative hypersthene was assumed to belong to the augite molecule, though the orthorhombic pyroxene may actually exist among the small pyroxene prisms, since we find it in the sorianal harzose from the same volcano. The results of the calculation were as follows:

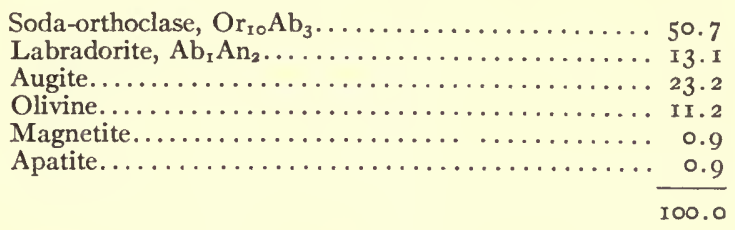

The calculation of the mode of the Colonetta rock was also simple. An amount of the normative hypersthene corresponding to that in the preceding case was assumed to enter into the augite molecule, while the balance was recalculated as olivine, the amount of which agrees fairly well with the appearance of the section. This calculation of olivine necessarily adds to the amount of free silica, which is stated as quartz, and which we must assume to be present in the glass base. In the case of both rocks the composition of the augite, apart from the hypersthene molecules, was assumed to be that of the Ticchiena augite referred to elsewhere. These readjustments give the following figures:

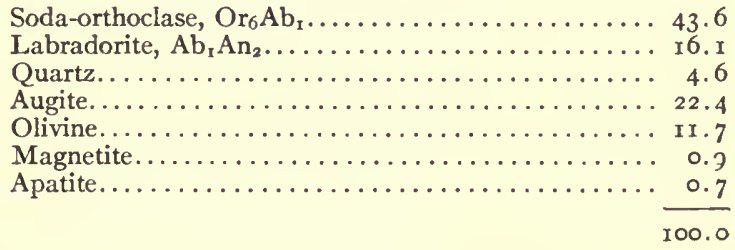

It is evident that the two modes are essentially identical, the amount of quartz or glass being so small as to be negligible. Taking the presence of olivine into account the type may be described as normative olivinic salfemphyro-ciminose; for which the shorter term "fiescolal ciminose" is an advantageous substitute.

The occurrence of quartz or a highly quaric glass along with olivine need not cause surprise, as a number of similar cases are well known. Indeed, from the generally observed easy solidification of highly quaric magmas or partial magmas before complete crystallization, the presence of glass in the specimen which shows some normative quartz, while that without this is holocrystalline, is readily intelligible.

Occurrence.-Rocks of this type are confined to the Ciminian District, so far as known. In this they are very abundant around the Cimino Volcano, and among representative localities may be mentioned the stream bed at Cavorcie, the quarry of the Chiesa dei Frati at Madonna della Quercia, a flow west of Villa Lante, flows and blocks in the tuffs at Monte Ciliano and near Soriano, and the type localities at La Colonetta and Fontana di Fiescoli.

Name.-The name of the subrang has been already explained as derived, like that formerly proposed for the group of trachytic rocks characterized by the presence 
of both orthoclase and labradorite with some olivine, from the name of the district. The type adjective is based on the locality, Fontana di Fiescoli, whence the original type specimen of ciminite came.

In the prevailing classifications these rocks have been given a wide diversity of names, almost every geologist who has studied the district having chosen a different one. Thus vom Rath calls them trachytes, Deecke augite-andesites, in both cases accompanied by remarks on their anomalous mineralogical and chemical characters; Bucca speaks of them as trachytes, Mercalli first called them olivine-trachytes and later olivine-andesites, while the name selected by Sabatini is "labradorite," used with the French signification.

In view of this confusion, which amounts to a tacit admission that the type belongs neither to the trachytes nor to the andesites, a special name seems advisable, and that formerly selected, "ciminite," is appropriate, as the rock is abundant at Monte Cimino and was at the time the only one which it seemed to be worth while to name. For these reasons Mercalli's recent criticism of the name "ciminite," on the ground that the rock does not make up the main part of Monte Cimino, seems to be somewhat strained.

FiEscolal ciminose. II. 5. 2. 2.

Megascopic characters.-Medium gray, compact, somewhat porphyritic. Feldspar phenocrysts few, I to $5 \mathrm{~mm}$., tabular or prismatic. Olivine phenocrysts rather abundant, I to $2 \mathrm{~mm}$., yellow. Augite phenocrysts rather abundant, I to $2 \mathrm{~mm}$., stout prismatic, black. Groundmass: rather light to rather dark gray, aphanitic.

Specific gravity 2.70 at $10^{\circ}$.

Microscopic characters.-Holocrystalline, rarely percrystalline, mediophyric, dopatic. Phenocrysts: about 25 per cent, olivine, augite, orthoclase, labradorite. Groundmass: about 75 per cent, orthoclase, labradorite, augite, olivine, magnetite, apatite, glass in rare cases. Groundmass, texture felted.

Orthoclase, about $\mathrm{Or}_{4} \mathrm{Ab}_{1}$. - Phenocrysts: about 3 per cent, I to $5 \mathrm{~mm}$., subhedral stout prismatic or tabular, Carlsbad twinning common, inclusions few. Groundmass: about 40 or 45 per cent, 0.02 to 0 . Io $\mathrm{mm}$., partly subhedral to anhedral, slender prismatic, arrangement diverse, partly anhedral, interstitial cement.

Labradorite, $\mathrm{Ab}_{1} \mathrm{An}_{2}$.-Phenocrysts: about 3 per cent, $\mathrm{I}$ to $5 \mathrm{~mm}$., subhedral to anhedral, stout prismatic, much twinned, often clustered, inclusions few. Groundmass: about ro per cent, 0.02 to 0. ro mm., anhedral, prismatic, arrangement diverse.

Augite-Phenocrysts: about 9 per cent, 0.2 to $2.0 \mathrm{~mm}$., subhedral to anhedral, stout prismatic, often fragmentary, colorless or very pale greenish, few inclusions. Groundmass: about I5 per cent, 0. or to $0.05 \mathrm{~mm}$, anhedral, slender prismatic, colorless.

Olivine.-Phenocrysts: about ro per cent, 0.5 to $2.0 \mathrm{~mm}$., subhedral, stout prismatic, tabular or equant, often corroded, colorless, commonly with narrow border of yellow iddingsite.

Magnetite.-Groundmass: about 2 per cent, 0.01 to $0.02 \mathrm{~mm}$., anhedral, equant.

A patite.-Groundmass: about I per cent, subhedral, slender prismatic.

Glass.-Usually absent: about 5 per cent, colorless, interstitial between feldspar laths, difficult to detect.

Chemical composition and norm as above.

Type specimens from Fontana Fiescoli and from La Colonetta, Cimino Volcano, Ciminian District. 


\section{5. 2. 2. Bagnoreal Ciminose [Leucite=Trachyte, Bagnorea Type].}

Megascopic characters. - Rocks of this type are light gray in color, and while porphyritic are not strikingly so, as the phenocrysts are neither numerous, large, nor conspicuous. . Those of leucite are most abundant, but constitute only from 5 to ro per cent of the rock. They are from $\mathrm{I}$ to $5 \mathrm{~mm}$. in diameter and usually anhedral to subhedral, crystal planes not being well developed. There are a few very small black prismoids of augite, with an occasional biotite table. The groundmass is rather light gray and quite aphanitic.

Microscopic characters. - In thin section the leucite phenocrysts show the usual characters, though the birefringence is weaker than in most cases and inclusions are rare. The phenocrysts of augite are subhedral, stout prisms, often fragmentary, and are of a somewhat greener tint than usual, though not markedly so. The biotite tables are brown, and for the most part are much altered to the common granular aggregate. Phenocrysts of feldspar are visible in the thin section, which escape observation in the hand specimen. They are of both orthoclase and plagioclase, the latter a labradorite of about $\mathrm{Ab}_{\mathrm{I}} \mathrm{An}_{2}$. Around these phenocrysts mantles of later alkali feldspar, oriented like the nuclear crystal, are not uncommon.

The groundmass is typically holocrystalline and shows an intersertal fabric. It is composed in large part of feldspar prisms, most of these being of orthoclase with fewer of labradorite, the arrangement being diverse, with the other groundmass constituents between the laths. Small round leucites are quite abundant, carrying few inclusions, and there are present in considerable amount small colorless augites, both in the form of subhedral prismoids and as anhedral, equant grains. Small grains of olivine are rather rare and the usual magnetite grains and apatite needles are seen. In some specimens there is a residual base of nephelite, interstitial between the other constituents, but this is not always found and its amount is very small in any case.

Chemical composition.-Incomplete analyses were made of two specimens of this type some years ago and are here republished, with several additional determinations.

Chemical Composition of Bagnoreal Ciminose [Leucite-trachyte].

\begin{tabular}{|c|c|c|c|c|c|c|c|c|c|}
\hline \multirow{9}{*}{$\begin{array}{l}\mathrm{SiO}_{2} \ldots \ldots \\
\mathrm{Al}_{2} \mathrm{O}_{3} \ldots \ldots \\
\mathrm{Fe}_{2} \mathrm{O}_{3} \ldots \ldots \\
\mathrm{FeO} \ldots \ldots \\
\mathrm{MgO} \ldots \ldots \\
\mathrm{CaO} \ldots \ldots \\
\mathrm{Na}_{2} \mathrm{O} \ldots \ldots \\
\mathrm{K}_{2} \mathrm{O} \ldots \ldots \\
\mathrm{H}_{2} \mathrm{O} \ldots \ldots \\
\mathrm{CO}_{2} \ldots \ldots \ldots\end{array}$} & \multicolumn{2}{|c|}{ I. } & \multicolumn{2}{|c|}{ II. } & & \multicolumn{2}{|c|}{ I. } & \multicolumn{2}{|c|}{ II. } \\
\hline & 55.85 & 0.931 & $55 \cdot 2 \mathrm{I}$ & 0.920 & $\mathrm{TiO}_{2} \ldots$ & 0.59 & 0.007 & $0.7 I$ & 0.009 \\
\hline & I8. 34 & . 180 & I8. 78 & .184 & $\mathrm{ZrO}_{2} \ldots$ & none & & 0.10 & \\
\hline & $3 \cdot 77$ & .024 & 2.69 & .017 & $\mathrm{P}_{2} \mathrm{O}_{5} \ldots$ & $0.3^{8}$ & .003 & 0.22 & .002 \\
\hline & I. 88 & .026 & 2.86 & .040 & $\mathrm{SO}_{3} \ldots \ldots$ & 0.05 & & none & \\
\hline & I. 73 & .043 & I. 68 & .042 & $\mathrm{MnO} \ldots$ & n.d. & & n.d. & \\
\hline & 3.84 & .069 & $4.6 I$ & .082 & $\mathrm{BaO} \ldots$ & 0.17 & & o. 18 & \\
\hline & $\begin{array}{l}3.39 \\
8.77\end{array}$ & $\begin{array}{l}.055 \\
.094\end{array}$ & $\begin{array}{l}3.13 \\
8.45\end{array}$ & $\begin{array}{l}.050 \\
.090\end{array}$ & & 99.90 & & $99.6 r$ & \\
\hline & $\begin{array}{l}\text { I. I4 } \\
\text { none }\end{array}$ & & $\begin{array}{l}0.99 \\
\text { none }\end{array}$ & & Sp. gr... & 2.648 & at $27^{\circ}$ & 2.609 & at $10^{\circ}$ \\
\hline
\end{tabular}

I. Bagnoreal ciminose [leucite-trachyte]. Bagnorea, Vulsinian District. H. S. Washington, analyst. Jour. Geol., V, 1897, p. 370.

II. Bagnoreal ciminose [leucite-trachyte]. Monte Venere, Ciminian District. H. S. Washington, analyst. Jour. Geol., IV, I896, p. 849. 
Norm of $I$.

Norm of $I I$.

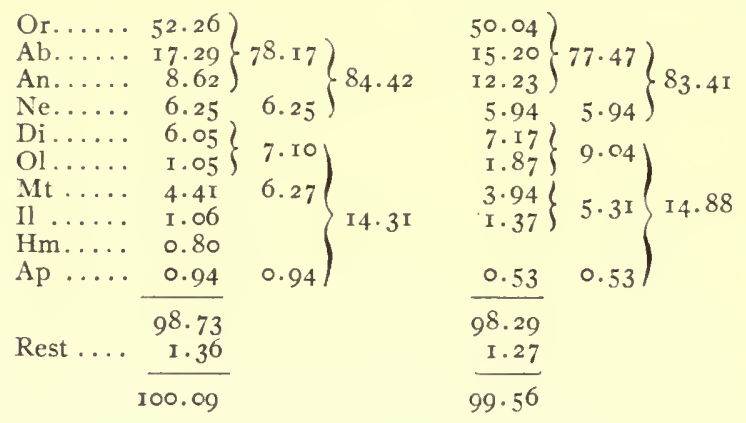

Ratios.

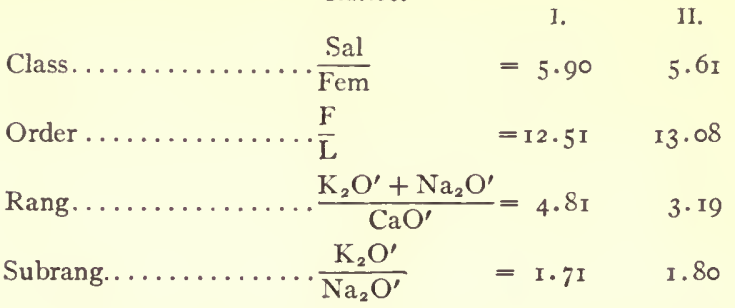

These two analyses are very closely alike and, corresponding to this, their magmatic positions are almost identical. They both fall well within the limits of all the subdivisions, except that of subrang, in which they are both rather near the sodipotassic border, almost enough so to be considered transitional, in which case the magmatic name would be monzonose-ciminose. As compared with the analyses of the fiescolal ciminose, this type is markedly higher in alumina and also in potash and soda, a point which will be referred to in discussing the mode.

Mode.-The modes of the two specimens analyzed were determined and may be discussed separately. In neither case could the colorless constituents of the groundmass, orthoclase, labradorite, and nephelite be accurately distinguished in the application of Rosiwal's method, so that these are stated together.

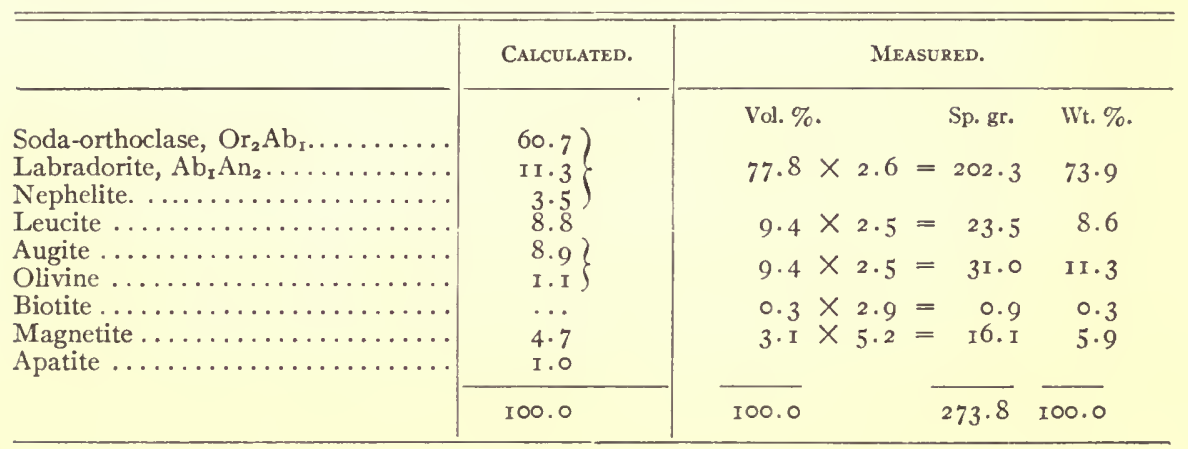


In the case of the Bagnorea specimen the phenocrysts, the leucite, the augite and olivine (measured together), and the magnetite were readily measured, the detailed reductions to weights being found in the formal description. In calculating the mode from the norm, after estimation of the augite on the usual basis as to composition, the amount of leucite determined by the microscopic measurements was assumed to be correct, since that of the nephelite could not be thus determined and a knowledge of the amount of one of the lenads was necessary.

As the Monte Venere rock contains no nephelite, all the soda was assumed to go into the albite molecule; and as it contains some biotite but no olivine, the normative olivine was combined with some leucite to form modal biotite. After these readjustments and the calculation of the augite of the usual composition, the remaining silica was distributed between orthoclase and leucite by the regular equations.

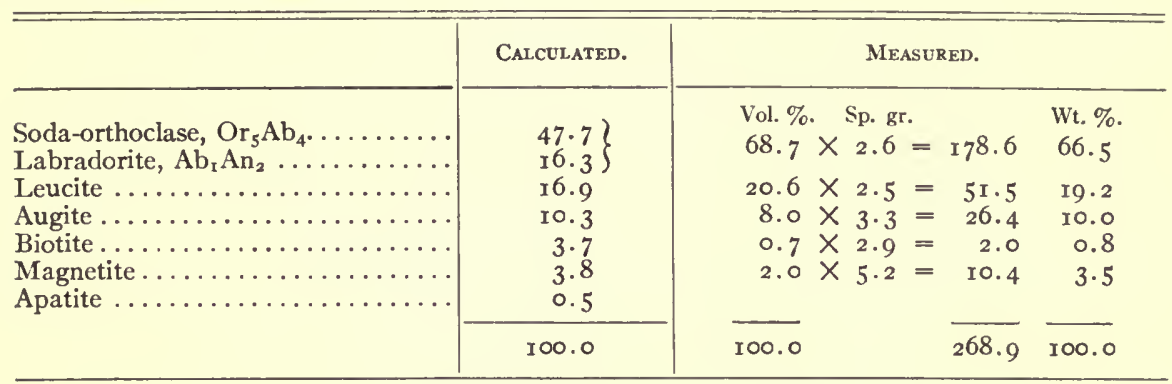

It will be seen that the calculated and measured modes in both cases agree very well and that the influence of overlapping has not been serious; indeed in the case of the Monte Venere rock the relations of light and dark minerals in the two modes are the reverse of those ordinarily obtained, the light and dark minerals being respectively less and more in the calculated than in the measured mode.

As compared with each other the modes of the two rocks are closely alike, though there are some differences, as the presence of nephelite and olivine in the Bagnorea rock and the presence of biotite in that from Monte Venere. But these differences are of slight moment, and may be regarded as negligible, at least for the present, when very fine distinctions are inadvisable.

Compared with the norms the two modes are evidently abnormative, especially in the replacement of nephelite (in whole or in part) and orthoclase by leucite, the other divergencies being negligible, so that the type may be spoken of as leucite alfersalphyro-monzonose-ciminose.

It is of some interest to compare the fiescolal ciminose [ciminite] with this type as regards chemical composition and mode. The chemical differences between the two, shown by the lower alumina and alkalis of the fiescolal type, have been adverted to above, and it is quite clear that the modal differences, and especially the presence of leucite, are largely dependent on these chemical differences. Indeed, in the case 
of the fiescolal type study of the norm and mode shows clearly that the presence of leucite in the rock to a notable extent would be most improbable on account of the presence of low alkalis, especially in view of considerable amounts of ferrous oxide and magnesia, which would allow the establishment of a silica equilibrium by the formation of olivine and hypersthene, the latter entering the augite molecule.

Occurrence.-This type is not very abundant, but probably more so than the number of specimens which I collected would indicate. It seems to be confined to the Vulsinian and Ciminian districts, prominent localities being the quarries at Bagnorea in the former and the flows of Monte Venere and one on the south shore of Lake Vico in the latter.

Name.-The name of the type is derived from that of the locality of Bagnorea, near Orvieto, where the rock is quarried extensively for paving stones.

In the prevailing systems the names commonly bestowed on these rocks vary with different observers, according to the particular minerals on which stress is laid. Thus the Bagnorea rock was formerly called by me leucite-phonolite on account of the nephelite cement present, while Bucca calls it a leucite-trachyte and Moderni a leucitophyre. Similarly the rock of Monte Venere was called by me a leucitetrachyte, while Mercalli and Sabatini consider it a leucite-teplirite, on account of the presence of labradorite, even in small amount. As may be gathered from the description above, and as is more evident from the discussion of the mode, the amounts of both labradorite and nephelite are so small that it would seem unwise, in bestowing a name, to allow their presence to offset the much more abundant orthoclase. On this account, in the prevailing systems, the name of leucite-trachyte is the most appropriate.

BAGNOREAL CIMINOSE. II. 5. 2. 2.

Megascopic characters.-Light gray, compact, porphyritic. Leucite phenocrysts few, I to $5 \mathrm{~mm}$., irregular, inconspicuous. Augite phenocrysts few, I to $2 \mathrm{~mm}$., black, prismatic, inconspicuous. Biotite phenocrysts few, I to $2 \mathrm{~mm}$., tabular, bronzy, sometimes wanting. Groundmass light gray, aphanitic.

Microscopic characters.-Holocrystalline to percrystalline, megaporphyritic, dopatic. Phenocrysts: Io to 15 per cent, leucite, augite, biotite, orthoclase, labradorite. Groundmass: 90 to 85 per cent, orthoclase, labradorite, leucite, augite, magnetite; also olivine, biotite, and nephelite, not always present. Glass base rare.

Orthoclase, from $\mathrm{Or}_{2} \mathrm{Ab}_{1}$ to $\mathrm{Or}_{1} \mathrm{Ab}_{\mathrm{r}}$. - Phenocrysts: about 2 per cent, not notable megascopically, 0.5 to $2.0 \mathrm{~mm}$., subhedral, stout prismatic, twinned. Groundmass: 45 to 55 per cent, 0.05 to $0.2 \mathrm{~mm}$., anhedral, prismatic and equant, arrangement of laths diverse.

Labradorite, $\mathrm{Ab}_{1} \mathrm{An}_{2}$. - Phenocrysts: about I per cent, not notable megascopically, 0.5 to $2.0 \mathrm{~mm}$., subhedral, stout prismatic, sometimes clustered, twinned. Groundmass: about Io to $\mathrm{r}_{5}$ per cent, 0.03 to $0.1 \mathrm{~mm}$., anhedral, prismatic, arrangement diverse.

Leucite.-Phenocrysts: about 5 to ro per cent, 0.5 to $5.0 \mathrm{~mm}$., subhedral to anhedral, equant, few inclusions. Groundmass: about 5 to Io per cent, 0.1 to $0.5 \mathrm{~mm}$., anhedral, equant, round sections, few inclusions.

Augite.-Phenocrysts: about 3 per cent, 0.2 to $2.0 \mathrm{~mm}$., subhedral to anhedral, prismatic and equant, often fragmentary, pale greenish-gray or colorless. Groundmass: about 7 per cent, 0.02 to $0.05 \mathrm{~mm}$., anhedral, prismatic and equant, colorless or very pale gray. 
Biotite.-Phenocrysts: about 3 per cent, not always present, 0.2 to $20 \mathrm{~mm}$., anhedral, thick tabular, brown, usually much altered. equant.

Olivine.-Groundmass: about I per cent, not always present, 0.03 to $0.2 \mathrm{~mm}$., anhedral,

Nephelite.-Groundmass: about 3 per cent, not always present, formless, interstitial cement. Magnetite.-Groundmass: about 4 per cent, $0.0 \mathrm{r}$ to $0.03 \mathrm{~mm}$., anhedral, equant.

A patite.-Groundmass: about $\mathrm{r}$ per cent, $0.0 \mathrm{r}$ to $0.04 \mathrm{~mm}$., anhedral, prismatic.

Chemical composition and norm as on p. 67 .

Type specimens from Bagnorea, Vulsinian District, and Monte Venere, Ciminian District.

\section{I1. 6-5. 2. 2. Martinal Vicose=Ciminose [Leucite='Tephrite, San Martino Type].}

Megascopic characters. - This type is rather light gray and resembles the bagnoreal ciminose. It is, however, much more highly porphyritic, phenocrysts of leucite and augite being abundant, though somewhat smaller than in the preceding type. Those of leucite are seldom over I $\mathrm{mm}$. in diameter and are very inconspicuous, while those of augite, in black prisms from I to $2 \mathrm{~mm}$. long, are much more so. The groundmass is a rather dark gray, dense, and aphanitic.

Microscopic characters.--In thin section the leucite phenocrysts are seen to be either subhedral or sometimes quite anhedral, from 0.5 to I mm., in diameter. They carry few inclusions, which consist of minute dusty grains, generally gathered toward the center. The subhedral augite prismoids are somewhat more abundant, are much cracked and fragmentary, though mostly with crystal planes remaining, and are either colorless or of an almost imperceptible greenish tinge. They contain no inclusions. These two minerals constitute the only phenocrysts, none of feldspar or biotite having been observed. The leucite phenocrysts commonly occur in clusters of several individuals.

The groundmass is somewhat indefinite and difficult of exact study. There are numerous small, colorless augite anhedra, which are either prismatic, equant, or irregular, and some small grains of magnetite, but none of the interstitial biotite seen in the previous type. These minerals are embedded in a colorless mass, which the crossed nicols resolve into very small, round anhedra of leucite, present in large numbers, indefinitely outlined prismoids of feldspar, which frequently show multiple twinning, though the grays are light and the structure is best seen with the aid of the selenite plate. Along with these are small flakes and indefinite interstitial areas of a colorless, feebly birefringent substance, which, however, does not seem to be nephelite, judging from the colors shown with the selenite plate, but is rather to be referred to one of the feldspars, probably orthoclase. No glass could be identified with certainty.

Chemical composition.--One analysis, hitherto unpublished, was made of this type. In its lower silica and alumina, as well as in its somewhat higher bivalent oxides, this analysis differs very considerably from those of the other ones of ciminose rocks. The explanation lies in the fact that, while this rock is well within the borders of the class, rang, and subrang, it lies close to the border of the lendofelic order. So close, indeed, is it that the type may be regarded as transitional 
between the subrangs ciminose (II. 5. 2. 2), where it falls, and that of vicose (II. 6. 2. 2), so that it should be called strictly a vicose-ciminose.

Chemical Composition of Martinal Vicose-ciminose [Leucite-tephrite].

\begin{tabular}{|c|c|c|c|c|c|}
\hline Constituent. & \multicolumn{2}{|c|}{ I. } & Constituent. & \multicolumn{2}{|c|}{ I. } \\
\hline 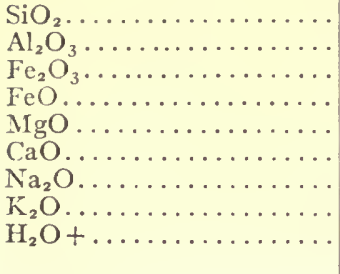 & $\begin{array}{r}52.14 \\
15 \cdot 91 \\
2.15 \\
5 \cdot 19 \\
5.11 \\
8.55 \\
1.92 \\
7.24 \\
0.10\end{array}$ & $\begin{array}{l}0.869 \\
.156 \\
.014 \\
.072 \\
.128 \\
.153 \\
.031 \\
.077\end{array}$ & 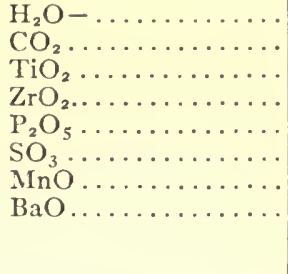 & $\begin{array}{r}0.09 \\
\text { none } \\
1.22 \\
\text { trace } \\
0.24 \\
0.07 \\
\text { n.d } \\
0.20 \\
100.13\end{array}$ & $\begin{array}{r}0.015 \\
.002 \\
.001\end{array}$ \\
\hline
\end{tabular}

Martinal vicose-ciminose [leucite-tephrite]. Fosso della Parchetta, San Martino, Ciminian Dis trict. H. S. Washington, analyst.

\section{Norm.}

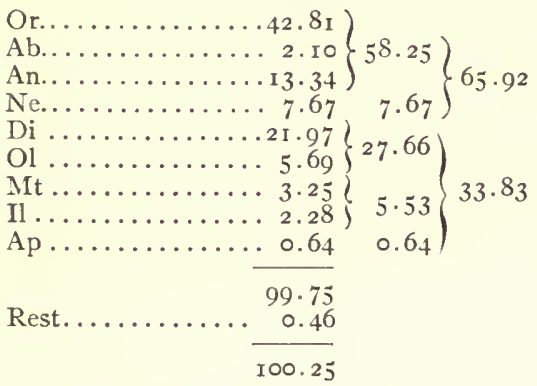

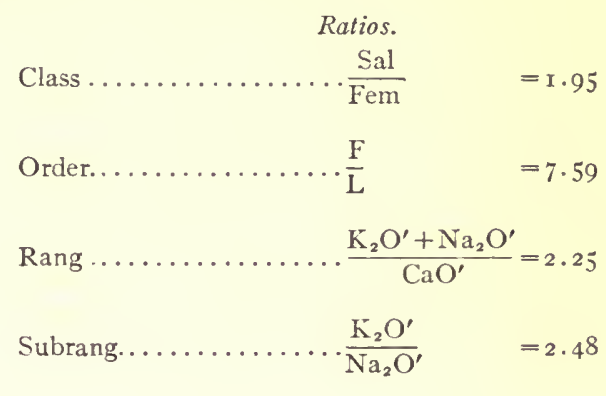

Mode.-While the amounts of the phenocrysts of leucite and augite could be accurately determined under the microscope, the constituents of the groundmass did not lend themselves to determination by Rosiwal's method on account of the indefinite character of the salic components, which had to be reckoned together. The following were the results obtained:

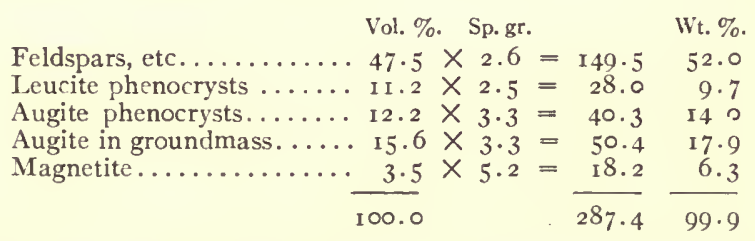

In calculating the mode from the norm it was assumed that no nephelite was present, and that "the alkali-feldspar had the composition $\mathrm{Or}_{1} \mathrm{Ab}_{\mathrm{I}}$. The assumption was made in regard to this rather than to the soda-lima feldspar, since it was difficult, if not impossible, to determine the average composition of this latter optically. The calculated composition of $\mathrm{Ab}_{4} \mathrm{An}_{3}$, an andesine, agrees as well as could be expected with the appearance under the microscope. The calculated mode is as follows: 


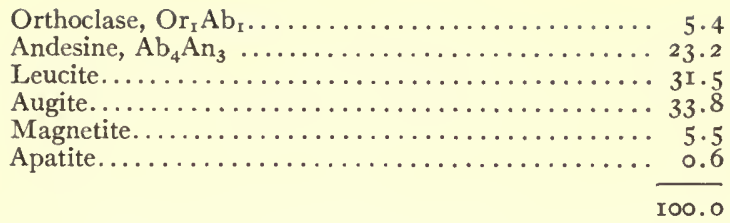

From the above it will be seen that about 2 I per cent of leucite is in the groundmass, the rest of the salic portion of this being of feldspars, altogether amounting to about $3 \mathrm{I}$ per cent. The calculated and measured amounts of augite and magnetite agree well, though the measured amount of the former is slightly lower than the calculated, the reverse being true of the ores. As compared with the norm, the only notable difference lies in the modal presence of leucite, replacing part of the orthoclase, and the total absence of nephelite. The type may then be called a leucite-alfersalphyro-ciminose.

Occurrence.-This type, so far as known, is found only in the neighborhood of San Martino, on the northwestern slope of the Vico Volcano in the Ciminian District, the best locality being at a quarry near the bridge over the Fosso della Parchetta. Rocks of the same type were also obtained behind the church of San Martino, above the town, and as blocks at the Ponte di Cetti, on the Via Aurelia, about $\eta \mathrm{km}$. southwest of Viterbo, these last being somewhat decomposed.

Name.-The type name is derived from the locality where the type occurs.

In the prevailing systems of classification this type would be regarded as a leucite-tephrite, on account of the very considerable amount of plagioclase and the small quantity of orthoclase.

MARTINAL VICOSE-CIMINOSE. II. 6-5.2. 2.

Megascopic characters.- Light gray, compact, highly porphyritic. Leucite phenocrysts abundant, but very small and inconspicuous. Augite phenocrysts abundant, small, prismatic, black. Groundmass light gray and aphanitic.

Microscopic characters.-Holocrystalline, mediophyric, dopatic. Phenocrysts: about 25 per cent, leucite, augite. Groundmass: about 75 per cent, somewhat felted fabric, andesine, leucite, augite, orthoclase, magnetite, apatite.

Orthoclase, $\mathrm{Or}_{\mathrm{I}} \mathrm{Ab}_{\mathrm{r}}$. - Phenocrysts none. Groundmass: about 5 per cent, 0.05 to $0.10 \mathrm{~mm}$., anhedral, prismatic and equant, also interstitial between the other constituents.

Andesine, $\mathrm{Ab}_{4} \mathrm{An}_{3}$.-Phenocrysts none. Groundmass: about 23 per cent, 0.05 to 0. ro $\mathrm{mm}$., anhedral, prismatic, outlines rather indefinite, twinned, arrangement diverse.

Leucite.-Phenocrysts: about II per cent, 0.4 to $\mathrm{I} .0 \mathrm{~mm}$., subhedral, equant, often clustered, few dusty inclusions. Groundmass: about 20 per cent, 0.02 to $0.05 \mathrm{~mm}$., anhedral, equant, free from inclusions, often difficult to distinguish from the groundmass orthoclase.

A ugite.-Phenocrysts: about I 2 per cent, 0.5 to $2.0 \mathrm{~mm}$., subhedral, prismatic, fusiform and fragmentary, colorless, no inclusions. Groundmass: about 20 per cent, 0.02 to $0.05 \mathrm{~mm}$., anhedral, prismatic, equant or irregular, colorless.

Magnetite.-Groundmass: about 4 per cent, 0.02 to $0.04 \mathrm{~mm}$., anhedral, equant.

Chemical composition and norm as on p. 72 .

Type specimen from Fosso della Parchetta, San Martino, Vico Volcano, Ciminian District. 


\section{5. 2. 3. Arsal Monzonose [Vulsinite, Arso Type].}

Megascopic characters.-Rocks of this type are very similar to those belonging to arsal vulsinose and ciminose described above, both megascopically and microscopically; so much so, indeed, that they are quite indistinguishable in the hand specimen.

The color is a pure gray which may vary from rather light to rather dark. Glistening, white, prismatic phenocrysts of feldspar, from 5 to $20 \mathrm{~mm}$. long, are rather abundant and are more or less conspicuous according as the groundmass is dark or light. With these are seen, but in very small amount, small black prisms of augite, and in still less quantity either small tables of biotite or grains of yellow olivine. The groundmass is dense and aphanitic. Most of the rocks of this type in the Roman Region are compact, but occasionally more or less vesicular forms are found.

Microscopic characters.-The feldspar phenocrysts are seen in thin section to be of both alkali and soda-lime feldspar, the amount of the former surpassing that of the latter. While the orthoclase is more or less sodic it does not show any of the microperthitic or other micro-structures which are so common in soda-orthoclase. The stout prisms are euhedral or subhedral, often twinned according to the Carlsbad law, and carry few inclusions. Those of soda-lime feldspar are similar in form and show the usual multiple twinning. The extinction angles vary somewhat, but in most cases indicate that the composition is near the border of andesine and labradorite, varying from $\mathrm{Ab}_{4} \mathrm{An}_{3}$ in the Arso rock to $\mathrm{Ab}_{3} \mathrm{An}_{4}$ in that from Poggio Cavaliere, and even slightly more calcic. It will be recalled that in the homologous types of vulsinose and ciminose the plagioclase was a labradorite about $\mathrm{Ab}_{1} \mathrm{An}_{2}$, or even an almost pure anorthite, the composition being, of course, correlated with the dopotassic or sodipotassic character of the subrang.

The augite phenocrysts call for little remark. They vary in length from $\mathrm{I}$ to $5 \mathrm{~mm}$., are usually anhedral, in stout prismoids or fragments of these, and are of the common very pale-gray color, sometimes slightly greenish-yellow. The rare biotite phenocrysts, which are not present in all specimens, are in thick tables, I to $3 \mathrm{~mm}$. wide, of the common brown color and usually much altered. In some specimens, as that from L'Arso, these are replaced by phenocrysts of olivine, from I to $2 \mathrm{~mm}$. in diameter, mostly anhedral, occasionally with crystal planes, colorless in thin section, and quite fresh.

The groundmass is composed very largely of slender laths of feldspar, those of orthoclase preponderating over those of soda-lime feldspar, which is an andesinelabradorite. In the Arso rock these small laths are branched at the ends and often slightly curved. Their arrangement is subparallel, giving rise to a trachytic fabric. With them are seen rarely, as in the Arso specimens, very small, round anhedra of leucite, but the amount of this is quite negligible, not over 2 per cent. and it is noteworthy that it does not occur in those rocks which show biotite phenocrysts, as that from Poggio Cavaliere. The presence of leucite in the Arso rock was first noted by 
vom Rath, but it was not observed by Fuchs. Its identity was established by the close resemblance to other occurrences, the evidences of the birefringence and twinning, and the presence in many cases of the characteristic minute inclusions of augite which are centrally arranged. The groundmass also carries the usual small colorless augite anhedra, in prisms and grains, and some small grains of magnetite. The specimens typically are holocrystalline, those from Cavaliere showing a little nephelite cement, but those from L'Arso carry a little glass, either colorless or brownish and often dusty with minute indeterminable microlites.

Chemical composition.-Analyses of two specimens of this type are found below, one of which has already been published in incomplete form, together with one by Riva of another type of monzonose which may be called bolsenal from the description by De Lorenzo, as well as an early one by Fuchs of the Arso rock, and also one of a monzonose from Montana.

Chemical Composition of Arsal Monzonose [Vulsinite].

\begin{tabular}{|c|c|c|c|c|c|c|c|c|}
\hline \multirow{3}{*}{ 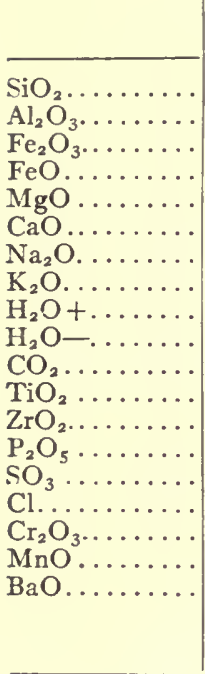 } & \multicolumn{2}{|c|}{ I. } & \multicolumn{2}{|c|}{ II. } & \multicolumn{2}{|c|}{ III. } & $\begin{array}{c}\text { IV. } \\
57 \cdot 73\end{array}$ & $\begin{array}{c}\mathrm{V} . \\
55.23\end{array}$ \\
\hline & 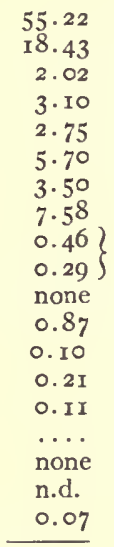 & $\begin{array}{r}0.920 \\
.18 I \\
.013 \\
.043 \\
.069 \\
.102 \\
.056 \\
.081\end{array}$ & $\begin{array}{r}56.75 \\
\text { I. } 03 \\
2.22 \\
3.04 \\
2.02 \\
4.68 \\
4.85 \\
5.92 \\
\text { o.18 } \\
\text { none } \\
\text { I.24 } \\
\ldots \ldots \\
\text { o.34 } \\
\ldots \ldots \\
\text { o.II } \\
\ldots \ldots \\
\text { n.d. } \\
\ldots \ldots \\
\end{array}$ & $\begin{array}{r}0.946 \\
.177 \\
.014 \\
.042 \\
.051 \\
.084 \\
.078 \\
.063\end{array}$ & $\begin{array}{r}54 \cdot 72 \\
19.60 \\
2.45 \\
3.09 \\
1.90 \\
5.00 \\
3.5^{2} \\
6.87 \\
2.08 \\
\ldots \ldots \\
0.65 \\
\ldots \ldots \\
\text { trace } \\
\ldots \ldots \\
0.05 \\
\ldots \ldots \\
\ldots \ldots \\
\ldots \ldots \\
\end{array}$ & $\begin{array}{r}0.912 \\
.192 \\
.015 \\
.043 \\
.048 \\
.089 \\
.056 \\
.073\end{array}$ & $\begin{array}{r}57 \cdot 73 \\
\text { I } 7.85 \\
4.44 \\
3.90 \\
\text { I. 77 } \\
3.65 \\
3.77 \\
7.65 \\
\text { o.o9 } \\
\ldots \ldots \\
\ldots \ldots \\
\ldots \ldots \\
\text { trace } \\
\ldots \ldots \\
\text { n.d. } \\
\ldots \ldots \\
\ldots \ldots \\
\ldots \ldots\end{array}$ & $\begin{array}{r}55.23 \\
18.31 \\
4.90 \\
2.06 \\
1.85 \\
3.62 \\
4.02 \\
6.43 \\
1.84 \\
\ldots \ldots \\
\ldots \ldots \\
0.42 \\
\ldots . .5 \\
0.58 \\
0.23 \\
0.32 \\
\ldots \ldots \\
\text { trace } \\
0.46 \\
\end{array}$ \\
\hline & $100.4 I$ & & $99 \cdot 3^{8}$ & & $99 \cdot 93$ & & 100.85 & 100.27 \\
\hline
\end{tabular}

I. Arsal monzonose [vulsinite]. Poggio Cavaliere, Lake Vico, Ciminian District. Washington, analyst.

II. Arsal monzonose [trachyte, ciminite]. L'Arso, Ischia, Campanian District. Washington, analyst. Am. Jour. Sci., VIII, I899, p. 290.

III. Bolsenal monzonose ["trachydolerite," vulsinite]. Ejected block, Astroni Volcano, Phlegrean Fields, Campanian District. Riva, analyst. De Lorenzo and Riva, Att. Acc. Sc. Nap., XI, I902, p. 37.

IV. Arsal monzonose [trachyte]. L'Arso, Ischia, Campanian District. Fuchs, analyst. Min. Pet. Mitth., I872, p. 230.

V. Aspenal monzonose [gauteite]. Aspen Creek, Highwood Mountains, Montana. Foote, analyst. L. V. Pirsson, Bull. U. S. G. S. No. 237,1905 , p. 134 . 
Norms.

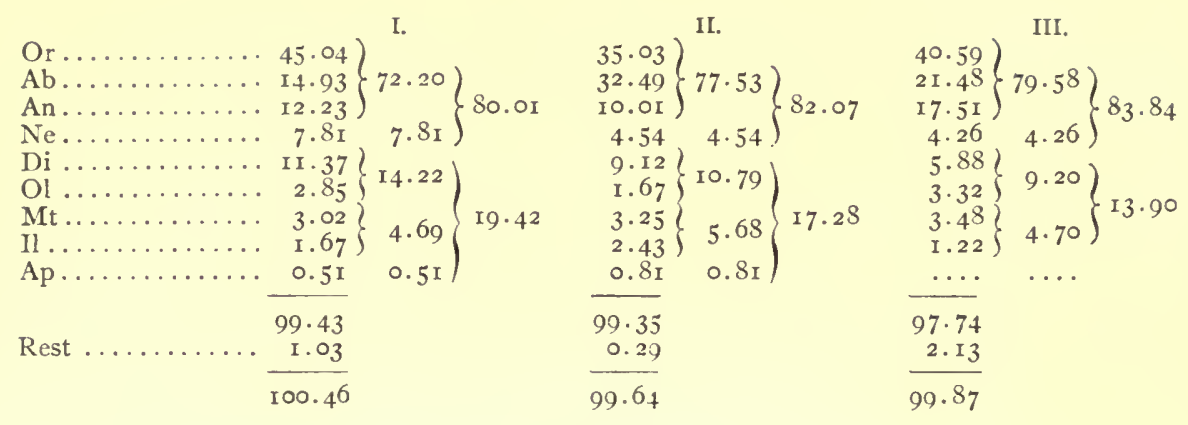

Ratios.

\begin{tabular}{|c|c|c|c|c|}
\hline Class. & $\frac{\text { Sal }}{\text { Fem }}$ & $\begin{array}{l}\text { I. } \\
=4.12\end{array}$ & $\begin{array}{l}\text { II. } \\
4 \cdot 75\end{array}$ & $\begin{array}{l}\text { III. } \\
6.03\end{array}$ \\
\hline Order & $\frac{\mathrm{F}}{\mathrm{L}}$ & $=9.24$ & 17.08 & ×8.68 \\
\hline Rang. & $\frac{\mathrm{K}_{2} \mathrm{O}^{\prime}+\mathrm{Na}_{2} \mathrm{O}^{\prime}}{\mathrm{CaO}^{\prime}}$ & $=3 . \mathrm{II}$ & $3.9^{2}$ & 2.05 \\
\hline Subra & $\frac{\mathrm{K}_{2} \mathrm{O}^{\prime}}{\mathrm{Na}_{3} \mathrm{O}^{\prime}}$ & $=\mathrm{I} .45$ & 0.83 & 1.30 \\
\hline
\end{tabular}

These analyses do not call for special comment. They are much alike in all respects and the rocks evidently fall well within the borders of the various divisions, except that that from Poggio Cavaliere lies somewhat close to the border of the dopotassic subrang, though not close enough to be considered transitional. The older analysis of the Arso rock by Fuchs, and a still earlier one by Abich, resemble that in II, except in their somewhat higher silica and potash and lower soda, but their dates and the conditions obtaining in analytical work and methods at the time render them not altogether reliable.

Mode.-The modes of the two specimens analyzed by me were determined and are here described. That of the bolsenal type can only be calculated from the norm, as the description of De Lorenzo is not quantitative.

In the case of Poggio Cavaliere rock determination of the mode by optical methods was rendered difficult by the size and arrangement of the groundmass feldspars and by the presence of the nephelite cement. Nor could the relative amounts of the phenocrysts of orthoclase and plagioclase be exactly estimated in the absence of sufficiently large sections. On the other hand, the amount of augite, both in phenocrysts and in the groundmass, and of the biotite phenocrysts, could be closely judged, the augite being about 16 per cent and the biotite about 1.8 of the rock by weight.

In calculating the mode from the norm the amount of biotite as thus determined was assumed to be correct, and the proper amounts of olivine and leucite molecules were assigned to it. The small amount of olivine remaining, changed to 
hypersthene, was assigned to the augite molecule, and the silica left after these readjustments and the calculation of orthoclase and anorthite was divided between albite and nephelite molecules in the usual way. The soda-lime feldspar was assumed to have the composition $\mathrm{Ab}_{3} \mathrm{An}_{4}$, thus leaving a little soda for the alkali-feldspar. The results of this calculation are:

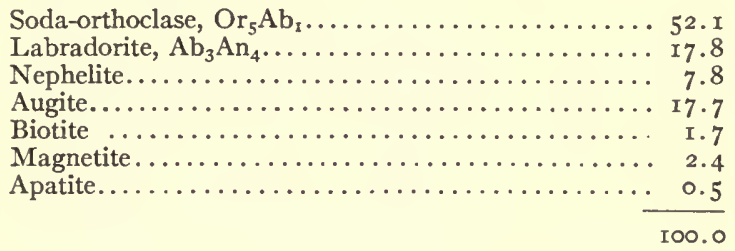

These figures agree with the appearance of the section. Thus the measured amount of the two feldspars and the nephelite base was about 77 per cent, while the calculated total for these is 77.7. The calculated amount of augite is slightly greater than the measured, and it is possible that some of the very small augites of the groundmass have been overlooked, but the divergence is not large. From treatment of the section with acid and fuchsine it would seem that the calculated amount of nephelite corresponds closely to the actual.

Taking up the Arso rock the same difficulites meet us, as regards the feldspars and glass cement, when it is attempted to estimate the mode by Rosiwal's method. But here, likewise, the amounts of leucite, augite, and olivine could be measured with a reasonable degree of certainty. The results are, for leucite 1.6 per cent, for augite I I per cent, and for olivine 2.I per cent, the total amount of phenocrystic and groundmass feldspars and glass being 84 , and that of ores about $\mathrm{r} .5$ per cent.

Although the texture is somewhat hyaline and the mode therefore is indeterminable, strictly speaking, the amount of glass is so small that the calculation of the mode from the norm may be attempted. For this purpose it was assumed that the amount of leucite was that shown optically and that the plagioclase had the composition shown below. The result is:
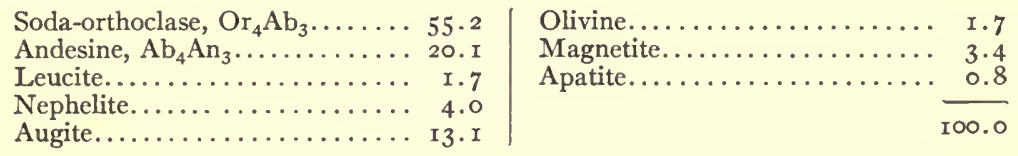

From the somewhat greater amounts of augite and magnetite shown by the calculated mode, and the presence of nephelite, it is clear that the glass cement is essentially a nephelite in composition (which is confirmed by the fact that it gelatinizes readily with acids), and that it carries considerable augite and magnetite, either as the fine, dusty microlites, or uncrystallized as the brownish coloring material. The olivine shown in the mode closely approximates to that of the norm.

It is of interest to note here that, instead of the small amount of modal biotite 
shown by the Cavaliere rock, this carries the leucite and olivine molecules crystallized as these minerals, and not combined into biotite.

It is clear that the modes of both specimens are essentially the same, as the amounts of biotite in the one and of leucite and olivine in the other are so small as to be quite negligible. As compared with the norm the differences are negligible also in both cases, and the type may be described, neglecting the small quantities of alferric phenocrysts, as normative salphyro-monzonose.

Occurrence.-This type is not abundant in the Roman Region, occurring rather sparingly in but two districts, the Ciminian and the Campanian. In the former it is best represented by a massive flow below the Poggio Cavaliere, on the south shore of Lake Vico, and it also forms blocks in the tuffs on the northwest slope of the Vico Volcano, especially near the Villa Balestra on the Via Aurelia, about $4 \mathrm{~km}$. southwest of Viterbo. In the Campanian District it forms the flow of I302 A. D., called L'Arso, on the island of Ischia, and a vesicular form occurs at Le Cremate, the point of eruption above the flow.

The type of bolsenal monzonose, which is based provisionally on the description and analysis of De Lorenzo and Riva, is met with as blocks at the Astroni Volcano in the Phlegrean Fields, but is not yet known outside the Campanian District, though it probably occurs elsewhere.

Name.-The subrang name is derived from that of Brögger's group of monzonites, many typical examples of which fall in this subrang. The type name is derived from the well-known locality of L'Arso. 'The possibility and the advisability of distinguishing two types, the arsal and the vetrallal, based on the conspicuousness of the feldspar phenocrysts and the presence of olivine or biotite, has already been discussed under the type of arsal vulsinose-ciminose (p. 6I).

The remarks on the position of the homologous types of vulsinose and ciminose in the prevailing systems are applicable here. In general these rocks would be called trachytes, but they are commonly recognized as rather abnormal. The Poggio Cavaliere rock would be a typical vulsinite, while that of L'Arso is distinguished by Rosenbusch from the true trachytes as the type of the Arso-typus, is often spoken of as an olivine-trachyte, and was formerly called a ciminite by me. It is noteworthy that the present measurements show the very small amount of olivine actually present, and emphasize again the prevalent tendency to exaggerate the importance of unusual constituents which may be present in negligible amounts.

De Lorenzo and Riva call attention to the chemical divergence of the bolsenal monzonose from the similar types which fall in vulsinose, and make this clear by naming the vulsinose rocks vulsinite, while the monzonose type is referred to as a trachydolerite.

ARSAL MONZONOSE. II, 5.2. 3.

Megascopic characters.-Medium gray, usually compact, porphyritic. Feldspar phenocrysts common, 3 to Io mm. long, stout prismatic, white, rather conspicuous. Augite phenocrysts rare, small, prismatic, black. Biotite phenocrysts not always present, few, small, tabular, 
black. Olivine phenocrysts not always present, few, small, yellow. Groundmass: gray, aphanitic.

Microscopic characters.-Holocrystalline to percrystalline, magnophyric, dopatic. Phenocrysts: about 20 per cent, orthoclase, andesine-labradorite, augite, biotite or olivine sometimes. Groundmass: about 80 per cent, either holocrystalline or with a very little glass, trachytic fabric, orthoclase, andesine-labradorite, augite, leucite (sometimes), nephelite (sometimes), magnetite, apatite, glass (sometimes).

Orthoclase, $\mathrm{Or}_{5} \mathrm{Ab}_{1}$ to $\mathrm{Or}_{4} \mathrm{Ab}_{3}$.-Phenocrysts: about ro per cent, I to $20 \mathrm{~mm}$., euhedral to subhedral, stout prismatic, Carlsbad twinning, inclusions rare. Groundmass: about 40 per cent, 0.05 to 0 . Io mm., anhedral, prismatic, sometimes branched, with diverse to subparallel arrangement.

Andesine-labradorite, $\mathrm{Ab}_{3} \mathrm{An}_{4}$ to $\mathrm{Ab}_{4} \mathrm{An}_{3}$.-Phenocrysts: about 5 per cent, 5 to $20 \mathrm{~mm}$., subhedral, stout prismatic, usually twinned, inclusions rare. Groundmass: about I5 per cent, 0.05 to $0.10 \mathrm{~mm}$., anhedral, prismatic, arrangement diverse to subparallel.

Leucite.-Phenocrysts none. Groundmass; not always present, sometimes about 2 per cent, 0.05 to 0 . Io $\mathrm{mm}$., anhedral round equant, faintly birefringent, some inclusions of augite microlites centrally arranged.

Nephelite.-Groundmass: not always present, up to about 8 per cent, anhedral, as cement interstitial between the feldspars.

Augite.-Phenocrysts: about 3 per cent, 0.5 to $2.0 \mathrm{~mm}$., subhedral to anhedral, stout prismatic and fragmentary, gray or very pale greenish-yellow, few inclusions. Groundmass: about Io per cent, 0.02 to $0.20 \mathrm{~mm}$., anhedral, prismatic, colorless or very pale yellowish.

Biotite.-Phenocrysts: not always present, sometimes about 2 per cent, I to $3 \mathrm{~mm}$., anhedral, thick tabular, much altered to granular aggregate.

Olivine.-Phenocrysts: not always present, sometimes about 2 per cent, I to $2 \mathrm{~mm}$., subhedral to anhedral, fusiform to equant, colorless and usually fresh.

Magnetite.-Groundmass: about 3 per cent, 0.01 to $0.03 \mathrm{~mm}$., anhedral, equant.

A patite.-Groundmass: about I per cent, 0.02 to $0.05 \mathrm{~mm}$., subhedral, prismatic.

Glass.-Groundmass: not always present, about 5 per cent, usually colorless, sometimes brown, dusty with minute microlites.

Chemical composition and norm as on p. 75

Type specimens from Poggio Cavaliere, south shore of Lake Vico, Ciminian District, and from L'Arso, Ischia, Campanian District.

\section{5. 2-3. 2. Foglianal Ciminose $=$ Auruncose $[$ Leucite $=$ Tephrite, Viterbo Type].}

Megascopic characters. - This type much resembles in the hand specimen the viterbal vulsinose and ciminose already described, though the only known example differs texturally in being somewhat smaller in grain, both as to phenocrysts and groundmass. The rock is a leucite melaphyre, leucite phenocrysts, which vary in diameter from I to $5 \mathrm{~mm}$. and which are usually euhedral, constituting about onefifth of the rock volume. There are much less abundant phenocrysts of feldspar and augite, but on account of their small dimensions these are very inconspicuous. The groundmass is rather dark gray and aphanitic. The only specimen obtained is somewhat vesicular.

Microscopic characters. - In thin section the leucite phenocrysts present no remarkable features. They are euhedral, sometimes clustered, with very faint double refraction, and carry few inclusions, mostly small round dots of glass and usually 
zonally arranged in thin bands parallel to the crystal outline. The great majority of the feldspar phenocrysts are of a labradorite, about $\mathrm{Ab}_{1} \mathrm{An}_{2}$, in euhedral, stout prisms, always twinned according to the usual laws. Phenocrysts of alkali-feldspar are less numerous, are somewhat less apt to be euhedral, and show Carlsbad twinning. The phenocrysts of augite of the usual pale-gray color are very rare, euhedral to subhedral, but often in fragments.

The groundmass in which these lie is extremely fine-grained. It is composed in large part of minute feldspar laths, which are of both orthoclase and soda-lime feldspar, though their small dimensions and absence of twinning render exact determination difficult. With them are many small prisms and grains of colorless augite, small anhedra of olivine, and some magnetites. Between these lies a colorless cement, which is in part doubly refracting, and may be considered to be feldspar, since nephelite is absent, judging from tests on the rock powder. In places this interstitial substance is isotropic, these areas being usually round and probably of leucite, though their very small size renders identification difficult. Glass may also be present to a small extent, but could not be definitely established.

Chemical composition.-But one analysis was made of this type, hitherto unpublished:

Chenical Composition of Foglianal Ciminose-auruncose [Leucite-tephrite].

\begin{tabular}{|c|c|c|c|c|c|}
\hline & \multicolumn{2}{|c|}{ I. } & & \multicolumn{2}{|c|}{ I. } \\
\hline 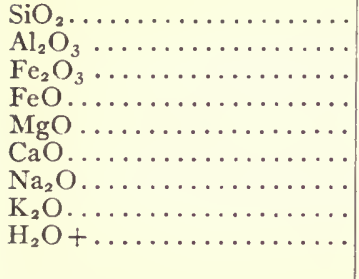 & $\begin{array}{r}52.37 \\
20.89 \\
1.21 \\
4 \cdot 44 \\
1.74 \\
5.08 \\
2.90 \\
7.47 \\
1.46\end{array}$ & $\begin{array}{l}0.873 \\
.204 \\
.008 \\
.062 \\
.044 \\
.091 \\
.047 \\
.080\end{array}$ & 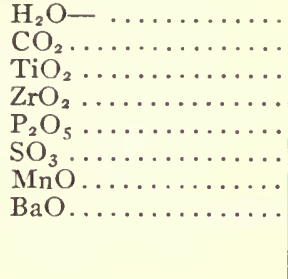 & $\begin{array}{l}0.5 \mathrm{r} \\
\text { none } \\
\text { r.I } 5 \\
0.07 \\
0.5 \mathrm{I} \\
\text { none } \\
\text { n.d } \\
\text { o. } 6 \\
99.96\end{array}$ & $\begin{array}{r}0.014 \\
.004\end{array}$ \\
\hline
\end{tabular}

Foglianal ciminose-auruncose [leucite-tephrite]. Croce di San Martino, Monte Vico, Ciminian District. H. S. Washington, analyst.
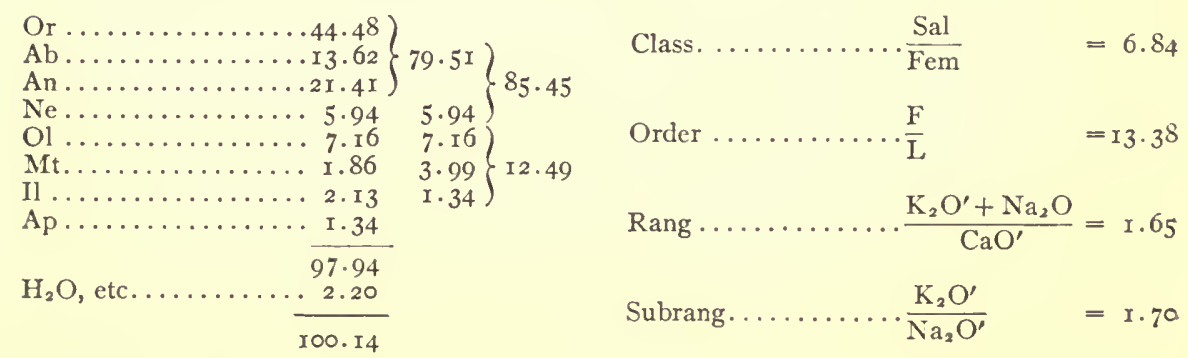
This analysis is not specially noteworthy in itself. Although the magnesia may appear to be low for a rock which carries olivine, the norm shows that considerable of this mineral may be present, more, indeed, than exists modally. The norm is remarkable among the rocks of the region in showing no diopside, all the femic lime being taken up by apatite. The alkalicalcic subrang is in harmony with the predominantly calcic character of the feldspar.

As regards its position in the quantitative classification the rock is an uncommonly transitional one. It falls well within the perfelic order, notwithstanding the considerable amount of leucite, but in class is in dosalane close to the border of persalane, in rang is almost exactly on the border between the domalkalic and alkalicalcic rangs, and in subrang is dopotassic but very close to the sodipotassic border. The proper symbol for its position then would be I-II. 5. 2-3.3-2, and the name of the magma corresponding to this would be extremely unwieldy. It seems best, therefore, to indicate in the magmatic name the two divisions in regard to which it is most transitional, so that the name of ciminose-auruncose has been selected.

Mode.-On account of the very fine grain and confused arrangement of the groundmass constituents only the phenocrysts could be estimated optically. Under these circumstances the calculation of the mode from the norm is unsatisfactory and must be based on several assumptions which may be only approximately correct. These were that about 5 per cent of leucite is contained in the groundmass, that the composition of the soda-lime feldspar phenocrysts is different from the feldspar of the groundmass, and that the amount of olivine is about 2 per cent. Making these assumptions, and with due regard for the optically estimated relations, we obtain the following mode:
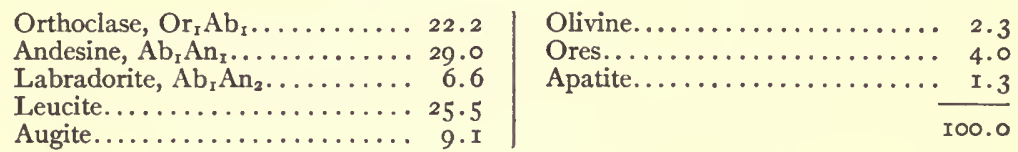

While this mode can not be regarded as more than a rough approximation, it is probably not very far from the actual facts. Compared with the norm, the mode differs mainly in the replacement of some of the orthoclase and all of the nephelite by leucite and in the existence of augite instead of olivine, very little of which is present modally. Taking these into consideration the type may be called an augitic leucite-salphyro-ciminose-auruncose.

Occurrence.-So far as known this type occurs only at one locality, a somewhat vesicular flow at the Croce di San Martino, on the northwest crest of the Vico crater ring, in the Ciminian District.

Name.-The derivation of the subrang name, auruncose, will be explained on a later page, while the type adjective is derived from Monte Fogliano, the western summit of the Vico Volcano. 
In the prevailing systems of classification the rocks of this type would best be called leucite-tephrite, on account of the preponderance of labradorite over orthoclase among the phenocrysts, as well as because there is somewhat more soda-lime feldspar than alkali feldspar in the mode.

FOGLIANAL CIMINOSE•AURUNCOSE. II. 5. 2-3. 2.

Megascopic characters.-Dark gray, sprinkled with numerous white phenocrysts of leucite. Leucite phenocrysts very abundant, I to $5 \mathrm{~mm}$., white, euhedral, conspicuous. Feldspar phenocrysts very few, small, inconspicuous. Augite phenocrysts few, prismatic, black, inconspicuous. Groundmass dark gray, aphanitic.

Microscopic characters.-Holocrystalline, mediophyric, dopatic. Phenocrysts: about 30 per cent, leucite, labradorite, orthoclase, augite. Groundmass: about 70 per cent, andesine, orthoclase, augite, leucite, olivine, magnetite, apatite. Fabric felted or hyalopilitic (?).

Orthoclase, $\mathrm{Or}_{\mathrm{I}} \mathrm{Ab}_{\mathrm{r}}$.-Phenocrysts: about 2 per cent, 0.5 to $\mathrm{I} .0 \mathrm{~mm}$., subhedral, stout prismatic, inclusions rare. Groundmass: about 20 per cent, part anhedral prismatic, 0.01 to $0.05 \mathrm{~mm}$., part as interstitial cement.

Andesine, $\mathrm{Ab}_{\mathrm{I}} \mathrm{An}_{\mathrm{I}}$.-Groundmass: about 30 per cent, 0.02 to $0.05 \mathrm{~mm}$., anhedral, part thin prismatic, part apparently as interstitial cement.

Labradorite, $\mathrm{Ab}_{1} \mathrm{An}_{2}$. - Phenocrysts: about 7 per cent, 0.5 to $2.0 \mathrm{~mm}$., euhedral, stout prismatic, twinned, inclusions rare.

Leucite.-Phenocrysts: about 20 per cent, I to $5 \mathrm{~mm}$., euhedral to subhedral, equant trapezohedra, often clustered, inclusions few. Groundmass: about 5 per cent, 0.02 to $0.05 \mathrm{~mm}$, anhedral, equant, inclusions few.

A ugite.-Phenocrysts: about I per cent, 0.5 to $1.0 \mathrm{~mm}$., subhedral, stout prismatic, pale greenish yellow, nonpleochroic. Groundmass: about 8 per cent, 0.005 to $0.02 \mathrm{~mm}$., anhedral, prismatic and equant, colorless.

Olivine.-Groundmass: about 2 per cent, 0.1 to $0.5 \mathrm{~mm}$., subhedral, stout prismatic to equant, colorless.

Magnetite.-Groundmass: about 4 per cent, 0.005 to $0.0 \mathrm{~mm}$., anhedral, equant.

Glass.-Groundmass: a very little may be present, but is not easily recognized.

Chemical composition and norm as on p. 80.

Type specimen from Croce di San Martino, Vico Volcano, Ciminian District.

\section{5. 2-3. 2. Teanal Ciminose-Auruncose [Leucite=Trachyte, Teano Type].}

Megascopic characters.-Rocks of this type are rather light gray and porphyritic, the phenocrysts of leucite, biotite, and augite being small and not very abundant. The grayish leucite phenocrysts vary from I to $5 \mathrm{~mm}$. in diameter, are subhedral to anhedral, and not very conspicuous. Those of the alferric minerals are smaller, seldom over $2 \mathrm{~mm}$. in length, and black, the biotite in thin tables and the pyroxtne in slender prisms. The compact, medium gray groundmass is aphanitic. In the field these rocks would be called biotite-leucite-leucophyres.

Microscopic characters. - In thin section the following minerals are seen to be present: Alkali feldspar, soda-lime feldspar, leucite, augite, biotite, ores, and apatite. The two feldspars are present in about equal amount and together make up about half the rock. As subhedral, stout prismoidal phenocrysts they are rare, being for the most part in the groundmass as anhedral patches and small laths, the former mostly of the alkali, and the latter of the soda-lime feldspar, though it is not always possible to distinguish clearly between them, except by the refractive indices, on 
account of the comparative rarity of multiple twinning in the plagioclase. The subhedral leucite phenocrysts carry few inclusions and call for no comment, except that they are not very abundant. The greater part of this mineral is in the groundmass, in very small, spheroidal anhedra, these and the phenocrysts both showing twinning lamellæ with the selenite plate. The augite phenocrysts and the groundmass prismoids are of the usual variety, subhedral and very pale gray in color, with few or no inclusions. Biotite exists only as small tabular phenocrysts, of a palebrown color, pleochroic, and for the most part deeply altered. The amount of magnetite is small, and the greater part is found as small anhedral grains scattered through the groundmass, though there are a few small phenocrysts. A little apatite is present in small prisms. Olivine is wanting, and neither nephelite nor glass could be detected.

Chemical Composition.-A specimen of this type from below Orchi was chosen for analysis, as it seemed to be fresher than those from near Teano. The analysis has not hitherto been published.

Chemical Composition of Teanal Ciminose-auruncose [Leucite-trachyte].

\begin{tabular}{|c|c|c|c|c|c|}
\hline \multirow[b]{2}{*}{ 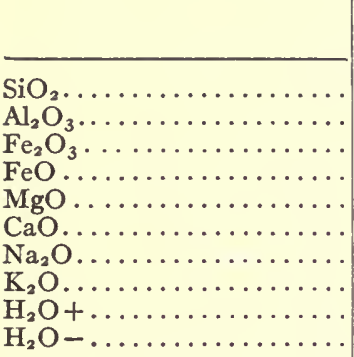 } & \multicolumn{2}{|c|}{ I. } & \multirow[b]{2}{*}{ 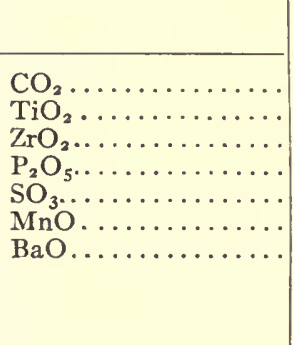 } & \multicolumn{2}{|c|}{ I. } \\
\hline & $\begin{array}{l}50.8 \\
18.4 \\
4 \cdot 0 \\
3 \cdot 4 \\
2 \cdot 5 \\
7 \cdot 7 \\
2 \cdot 2 \\
7 \cdot 1 \\
1.5 \\
0.1\end{array}$ & $\begin{array}{r}0.848 \\
.181 \\
.025 \\
.048 \\
.064 \\
.139 \\
.035 \\
.077\end{array}$ & & $\begin{array}{l}\text { none } \\
\text { I.00 } \\
0.02 \\
0.46 \\
\text { none } \\
\text { n.d. } \\
\text { o.1 } 7 \\
99.84\end{array}$ & 0.013 \\
\hline
\end{tabular}

Teanal auruncose [leucite-trachyte]. Below Orchi, Auruncan District. Washington, analyst.

Norm.

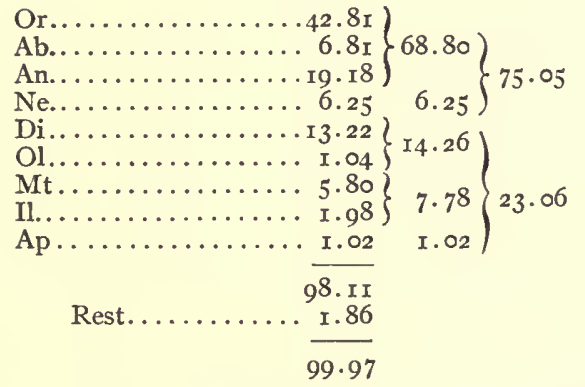

Ratios.

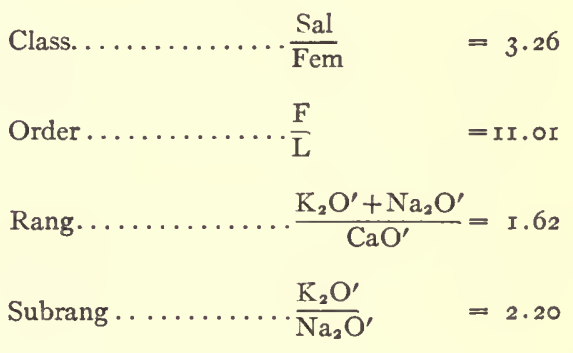

The general similarity of this analysis to that of the orvietal type next to be described is quite close. The analysis of the teanal auruncose shows that this type is well within the borders of class, order, and subrang, but so close to 
the border of the domalkalic rang that the type is really transitional and the magma a ciminose-auruncose. This is in harmony with the facts noted below that the orvietal auruncose would be termed leucite-tephrite in prevailing systems, on account of the more prominent labradorite, while the teanal type, in which the soda-lime feldspar is less important, would rather be called a leucite-trachyte.

Mode.-The mode of this type could be measured microscopically very satisfactorily, except that the groundmass feldspars had to be lumped together. The readjustments of the normative molecules to calculate the mode offered no points of difficulty or special interest, the measured amount of leucite being assumed, and otherwise the calculations being carried out as in previous cases.

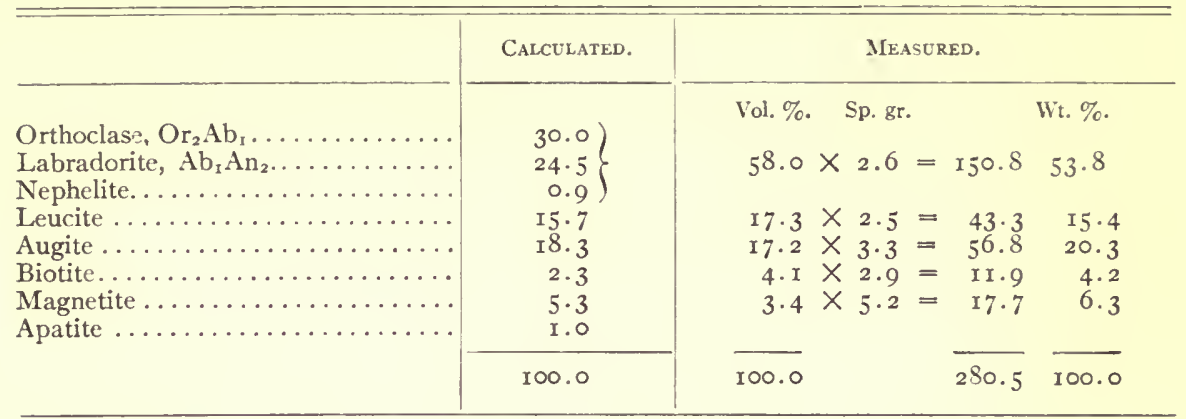

The two agree very well, though the calculations show that a very small amount of nephelite is probably present, which might easily escape detection. The error due to overlapping of the colored minerals is noticeable, but not serious. The calculated amount of biotite is that derived from all the normative olivine, and it is notably less than the measured. The discrepancy is to be attributed to the general and profound alteration of the biotite tables to a fine-grained aggregate of augite and magnetite, which were measured with the unaltered portions as biotite. As compared with the norm, leucite is the critical mineral and biotite the varietal, and as the fabric of the groundmass is granular rather than trachytic, the type may be described as biotitic leucite-graniphyro-ciminose-auruncose.

Occurrence.-The only known occurrences of teanal auruncose are in the Auruncan District, where it seems to be fairly common. Specimens were obtained in the southeastern part near Teano, as at Tuoro, as well as below Orchi, on the northern slope of the volcano.

Name.-As mentioned above, the subrang name is derived from that of the district where it seems to be most abundant. That of the type comes from the town of Teano, near which the type is met with.

In the prevailing classifications these rocks could be called either leucite-tephrites or leucite-trachytes, but as the alkali-feldspar is the more prominent, the name of leucite-trachyte would seem to be the most appropriate, and was the one given the type in a former description. 
TEANAL CIMINOSE-AURUNCOSE. II. 5. 2-3. 2 .

Megascopic characters.-Medium gray, compact, porphyritic. Feldspar and leucite phenocrysts few, I to 5 mm., white, not very conspicuous. Augite phenocrysts few, I to 2 mm., prismatic, black. Biotite phenocrysts few, $\mathrm{r}$ to $4 \mathrm{~mm}$., thin tabular. Groundmass, gray, aphanitic.

Microscopic characters.-Holocrystalline, mediophyric, perpatic to dopatic. Phenocrysts: about I5 per cent, leucite, biotite, orthoclase, labradorite, augite. Groundmass: about 85 per cent, somewhat interstitial fabric, orthoclase, labradorite, leucite, augite, magnetite, apatite, nephelite.

Orthoclase, $\mathrm{Or}_{2} \mathrm{Ab}_{1}$.-Phenocrysts: about 2 per cent, $\mathrm{I}$ to $2 \mathrm{~mm}$., subhedral, stout prismatic, untwinned. Groundmass: about 28 per cent, 0.05 to $0.20 \mathrm{~mm}$., anhedral, irregular patches, sometimes interstitial.

Labradorite, $\mathrm{Ab}_{1} \mathrm{An}_{2}$ - - Phenocrysts: about 2 per cent, I to $2 \mathrm{~mm}$., subhedral, stout prismatic, twinned. Groundmass: about 22 per cent, 0.02 to $0.10 \mathrm{~mm}$., subhedral, thin prismatic, twinned, arrangement diverse.

Leucite.-Phenocrysts: about 4 per cent, I to $5 \mathrm{~mm}$., subhedral, equant, inclusions few. Groundmass: about r 2 per cent, 0.05 to o. ro mm., anhedral, spheroidal, few inclusions.

Nephelite.-Groundmass: about I per cent, anhedral, interstitial, difficult to detect.

Augite.-Phenocrysts: abouk 5 per cent, 0.30 to $2.0 \mathrm{~mm}$., subhedral to anhedral, stout prismatic to equant and irregular, pale greenish-gray, few inclusions. Groundmass: about 13 per cent, 0.02 to $0.10 \mathrm{~mm}$., subhedral, prismatic, very pale greenish-gray.

Biotite.-Phenocrysts: about 4 per cent, $\mathrm{I}$ to $4 \mathrm{~mm}$., subhedral, thin tabular, brown, usually much altered. Groundmass: none.

Magnetite.-Groundmass: about 5 per cent, 0. or to 0.02 , anhedral, equant.

A patite.-Groundmass: about I per cent, 0.02 to $0.05 \mathrm{~mm}$., subhedral, prismatic.

Chemical composition and norm as on p. 83 .

Type specimen from below Orchi, Auruncan District.

\section{5. 3. 2. Orvietal Auruncose [Leucite-Tephrite, Orvieto Type].}

Megascopic characters. - These rocks are of a uniform ash-gray color, and differ from those yet described in being entirely devoid of phenocrysts. They are, however, not aphanitic, since the mineral particles are distinguishable to the naked eye, on close inspection, as white and dark, the former predominating.

Microscopic characters.-Study of the thin sections shows that microphenocrysts are almost entirely wanting, only very few individuals of augite and an exceptional one of feldspar attaining dimensions notably greater than others, and the length even of these is seldom more than $0.5 \mathrm{~mm}$. The texture shows no marked hiatus in the sizes of the particles, and the extreme limits in size of the various minerals are approximately the same. The fabric is intersertal, through the diverse arrangement of the feldspar laths.

The feldspar, which constitutes about 50 per cent of the rock, is in part a sodic orthoclase, in untwinned anhedra, up to $0.4 \mathrm{~mm}$., in length. The borders are very irregular, and this mineral plays the rôle, to a large extent, of mesostasis for the other constituents. There is about an equal amount of labradorite, with the average composition $\mathrm{Ab}_{2} \mathrm{An}_{3}$, in small plates and laths, which exhibit the usual multiple twinning. Leucite is quite abundant, about 16 per cent, in equant anhedra from 0.05 to $0.2 \mathrm{~mm}$. in diameter, which often carry a few inclusions of colorless augite either centrally or zonally arranged. The augite, which forms about one-fifth of 
the rock, is of the usual very pale gray and for the most part in subhedral to anhedral prismoids of about the same size as the leucites. Brown biotite is present in very subordinate amount, not over 4 per cent, in the form of small, irregular patches between the subhedral minerals, not that of tabular phenocrysts. About the same amount of magnetite occurs in the customary small grains. A little olivine was found in small crystals, and there is a very little interstitial nephelite cement, the last product of solidification.

Chemical composition.-An analysis was made of a specimen from the massive flow on which the town of Toscanella is built, taken from below the town in the ravine of the Marta, near the west gate. The analysis does not call for much comment here. It will be noticed that the silica is quite low, as well as the potash, while the lime is rather high.

Chemical Compositon of Orvietal Auruncose [Leucite-tephrite].

\begin{tabular}{|c|c|c|c|c|c|}
\hline & \multicolumn{2}{|c|}{ I. } & & \multicolumn{2}{|c|}{ I. } \\
\hline 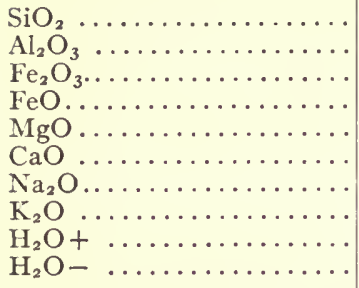 & $\begin{array}{r}51.21 \\
18.28 \\
3.07 \\
4.19 \\
3.47 \\
7.86 \\
2.49 \\
6.60 \\
0.56 \\
0.16\end{array}$ & $\begin{array}{r}0.854 \\
.179 \\
.019 \\
.058 \\
.087 \\
.140 \\
.040 \\
.070\end{array}$ & 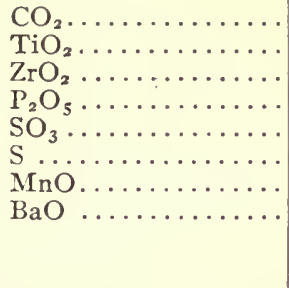 & $\begin{array}{l}\text { none } \\
\text { I. } 43 \\
\text { none } \\
0.35 \\
\text { none } \\
\text { none } \\
\text { n.d. } \\
0.10 \\
99.77\end{array}$ & $\begin{array}{r}0.018 \\
.003\end{array}$ \\
\hline
\end{tabular}

Orvietal auruncose [leucite-tephrite], Toscanella, Vulsinian District. Washington, analyst.

Norm.

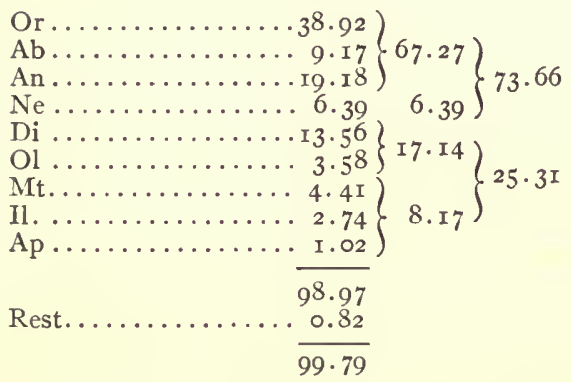

Ratios.

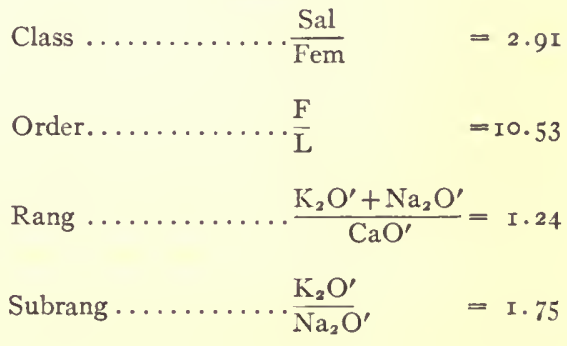

Mode.-The mode of the Toscanella rock was determined both by Rosiwal's method and by calculation from the norm. In the former the amounts of leucite and biotite could be measured with a very considerable degree of exactness, while the two feldspars and the nephelite were necessarily measured together, as was the case with the augite and olivine. In calculating the mode from the norm, therefore, the measured amounts of leucite and of biotite were assumed to be correct, as some such assumptions were necessary to distribute the potash between orthoclase, leucite, and biotite, and the normative olivine molecules between modal biotite and olivine. 
The distribution of the soda was fixed by the composition of the plagioclase and the use of the usual equations.

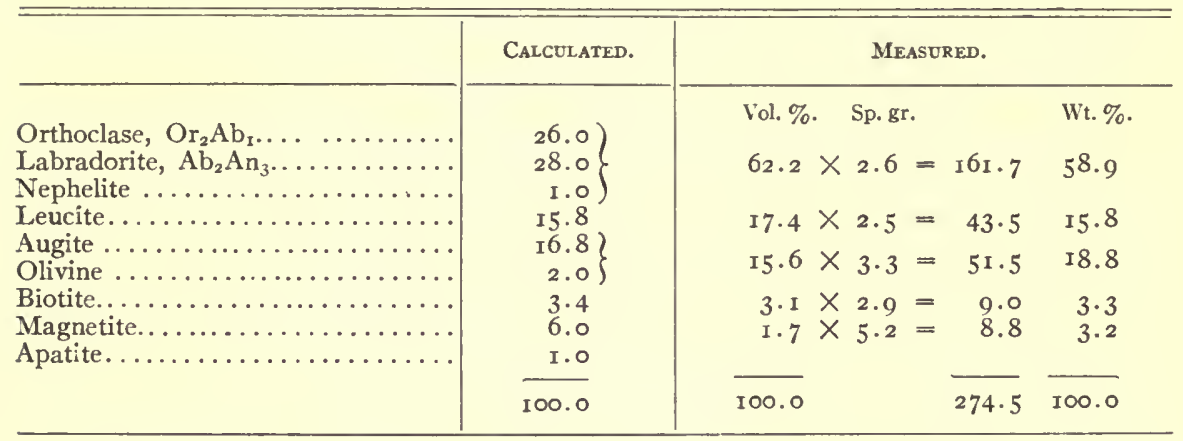

The two modes resemble each other very closely, except that in the calculated one the amount of magnetite is considerably greater than in the measured. As compared with the norm, the only difference of importance is the modal presence of leucite, which replaces much of the orthoclase and changes most of the normative nephelite to albite. The readjustments involved by the presence of augite and biotite are small and negligible. The type may therefore be described as leucitegrani-auruncose.

Occurrence.-Orvietal auruncose is a rare rock, the only known example forming flows near Toscanella, in the Vulsinian District. It very probably occurs elsewhere in the same district, and possibly in the Auruncan, but no other rocks of similar type can, as yet, be definitely referred to this magma.

Name.-The name of the subrang is derived from the Auruncan District, where this magma seems to be common, though usually of another type. The type name is derived from the city of Orvieto in the Vulsinian District, near which a homologous type of the vicose magma is met with.

In the prevailing systems of classification the type would be called a leucitetephrite, as stress is laid especially on the soda-lime feldspar.

\section{ORVIETAL AURUNCOSE. H. 5.3.2.}

Megascopic characters.-Light gray, compact, aphyric, very fine-grained, phanerocrystalline.

Microscopic characters.-Holocrystalline, serial heterometric. Orthoclase, labradorite, leucite, augite, biotite, olivine, ores, nephelite, apatite. Fabric subintersertal.

Orthoclase, $\mathrm{Or}_{2} \mathrm{Ab}_{1}$. - About 25 per cent, 0.05 to $0.40 \mathrm{~mm}$., anhedral, irregular patches, largely intersertal, untwinned.

Labradorite, $\mathrm{Ab}_{2} \mathrm{An}_{3}$.-About 28 per cent, 0 . ro to $0.40 \mathrm{~mm}$., subhedral to anhedral, tabular, twinned, arrangement diverse.

Leucite.-About I6 per cent, 0.05 to $0.20 \mathrm{~mm}$., anhedral, equant, small inclusions of augite, zonally or centrally arranged.

Nephelite.-About I per cent, anhedral, interstitial cement.

Augite.-About I 7 per cent, 0.05 to $0.20 \mathrm{~mm}$., subhedral to anhedral, prismatic to equant, pale gray, no inclusions. 
Biotite.-About 4 per cent, 0.05 to o. ro mm., anhedral, irregular patches, pale brown, pleochroic.

Magnetite.-About 4 per cent, 0.02 to $0.05 \mathrm{~mm}$., anhedral, equant.

A patite.-About I per cent, 0.05 to 0 . ro mm., subhedral, prismatic.

Chemical composition and norm as on p. 86.

Type specimen from below Toscanella, Vulsinian District.

\section{5. 3. 3. Monfinal Shoshonose [Biotite=Latite, Monfina Type].}

Megascopic characters. - This rock, which is only met with in the region as a domal eruption, is highly porphyritic, showing many small, glistening, black tables of biotite and small greenish-black augite prisms, with numerous, but much less conspicuous, small, stout prisms of feldspar in a very fine-grained, phanerocrystalline groundmass, which is very light gray, but with a slightly pinkish tone. The field name for the type would be biotite leucophyre.

Microscopic characters.- The most abundant phenocrysts are alferric, of a greenish-brown biotite in thin tables, which are fresh in the interior but with a thin border of alteration products, and of subhedral, stout prismoids of the usual augite, though its color is apt to be slightly more green than in the types just described. Phenocrysts of feldspar are rather less numerous, though common, and consist of both labradorite $\left(\mathrm{Ab}_{2} \mathrm{An}_{3}\right)$ and soda-orthoclase. These are subhedral, stout prisms, whose average lengths, like those of the alferric phenocrysts, run from 0.5 to I mm., seldom being greater than $2 \mathrm{~mm}$.

The groundmass in which these lie is very largely composed of slender laths of feldspar, here mostly soda-orthoclase, with less labradorite, these being arranged fluidally, so that the fabric is a typical trachytic one. With them are small augite prismoids, small magnetite anhedra, and very few apatite needles. All these lie in a clear, colorless base, which is not isotropic, but which everywhere shows a distinct, though somewhat faint, birefringence. As will be seen later, when the norm and the mode are discussed, this base is in all probability either quartz or a mixture of quartz and alkali-feldspar.

Chemical composition.-An analysis of this type, made several years ago, is here repeated with additional determinations. For comparison there is also given an analysis of another type of shoshonose from Radicofani, the magma of which is probably connected with the Vulsinian District.

Chemical Composition of Monfinal Shoshonose [Biotite-latite].

\begin{tabular}{|c|c|c|c|c|c|c|c|c|c|}
\hline \multirow{9}{*}{ 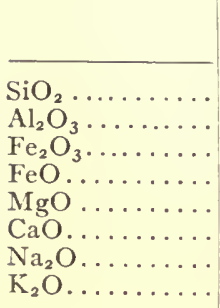 } & \multicolumn{2}{|c|}{ I. } & \multicolumn{2}{|c|}{ II. } & & \multicolumn{2}{|c|}{ I. } & \multicolumn{2}{|c|}{ II. } \\
\hline & 55.69 & 0.928 & $54 \cdot 5^{6}$ & 0.909 & $\mathrm{H}_{2} \mathrm{O}+\ldots \ldots$ & 0.17 & & 0.15 & \\
\hline & 17.87 & .175 & 16.49 & .162 & $\mathrm{CO}_{2} \ldots \ldots$ & none & & none & \\
\hline & 4.07 & .025 & I. 02 & .006 & $\mathrm{TiO}_{2} \ldots \ldots$ & $\mathrm{I} .02$ & 0.013 & I. IO & 0.014 \\
\hline & 3.26 & .045 & 5.65 & .078 & $\mathrm{P}_{2} \mathrm{O}_{5} \ldots$ & 0.10 & .001 & n.d. & \\
\hline & $3.4 \mathrm{I}$ & .085 & 8.57 & .214 & $\mathrm{MnO} \ldots \ldots$ & n.d. & & n.d. & \\
\hline & 6.87 & .123 & 7.95 & .142 & & & & & \\
\hline & 2.89 & .047 & 2.07 & .033 & & 99.85 & & 100.91 & \\
\hline & $4 \cdot 4 \mathrm{I}$ & .047 & $3 \cdot 35$ & .036 & Sp.gr.... & 2.717 & & & \\
\hline
\end{tabular}


Notes Explanatory of Preceding Table.

I. Monfinal shoshonose [biotite-vulsinite]. Monte Santa Croce, Auruncan District. Washington, analyst. Jour. Geol., V, 1897, p. 252.

II. Radicofanal shoshonose [andesite]. Radicofani, Tuscany. Washington, analyst. Am. Jour. Sci., IX, 1900, p. 52 .

Norm of $I$.

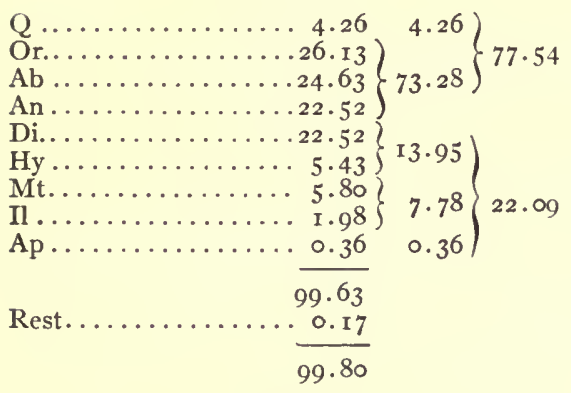

Norm of $I I$.
Ratios of $I$.

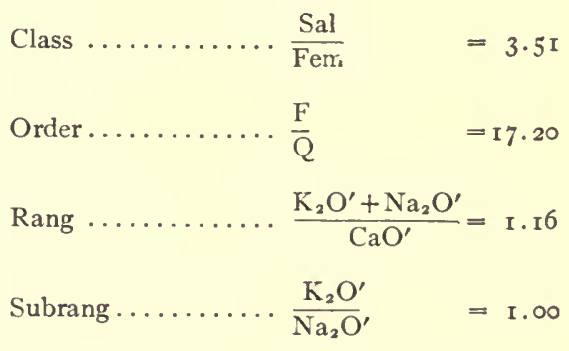

Ratios of II.

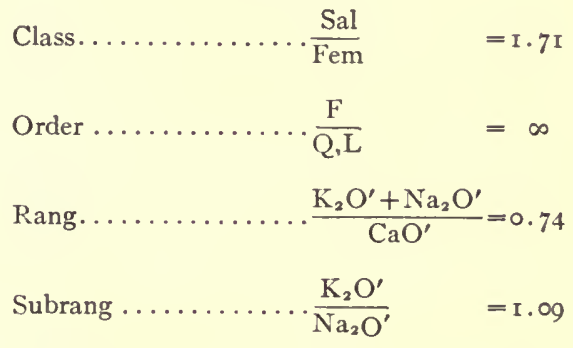

From the norm of I it is clear that the Santa Croce rock is well within the borders of all the magmatic divisions, or, in other words, is an almost central shoshonose. The Radicofani rock, on the other hand, which carries augite and very little olivine as alferric minerals, but no biotite, is evidently richer in these, as it is almost in the salfemane class. It will be noted also that the monfinal type shows an excess of silica, appearing as normative quartz, while the radicofanal has deficient silica, giving rise to some normative olivine.

Mode.-The mode of this type could not be determined by Rosiwal's method, on account of the very fine grain and the mineralogical character of the groundmass, though the relative amounts of the phenocrysts, including all of the biotite, were estimated with accuracy, the results of which appear in the formal description. In calculating the mode from the norm by readjustment the observed amount of biotite was taken as a starting-point. That this is probably correct is shown by the fact that this amount takes up all of the normative hypersthene, with silica lowered to form olivine ( 3.84 per cent), which with an almost equal amount of leucite $(3.5$ per cent), assumed to form biotite, makes just 7.3 per cent of this mineral. The 
silica thus set free in the formation of biotite from the more highly silicated minerals hypersthene and orthoclase, having nothing to combine with, must be present as quartz or as a quaric glass.

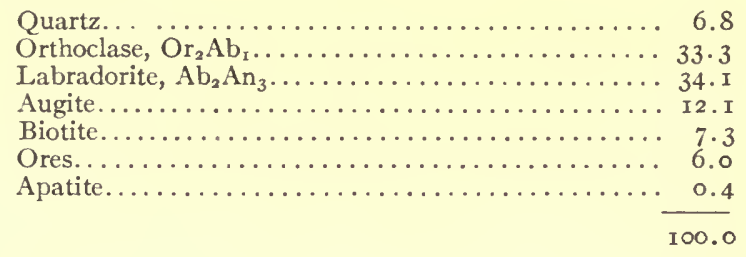

From the above it is clear that a certain amount of quartz must be present in the rock, and this is to be looked for in the rather ill-defined, colorless, anisotropic, interstitial base already mentioned. The feldspar laths and what are clearly anhedra of orthoclase are so closely juxtaposed that study of this base is difficult, but the mean index of refraction appears to lie between those of orthoclase and labradorite and the rock does not furnish any gelatinous silica on treatment with acid. The mode as thus calculated corresponds with the thin sections of the rock as well as can be estimated, and may be considered as close to the truth.

The variation of the mode from the norm appears chiefly in the presence of biotite, the other readjustments being of minor importance. The type may therefore be described as a biotite trachiphyro-shoshonose.

Occurrence.-This type is a decidedly rare one, occurring only in the Auruncan District, and here only at the central dome of Monte Santa Croce, which is composed apparently entirely of it, and at the adjoining small hill of Monte Lattani in an altered condition.

Name.-The name of the subrang is derived from that of Iddings's group of shoshonites, many of which fall here. The type name is derived from that of the volcano of Rocca Monfina, itself so called from the name of the village at the foot of Monte Santa Croce, where the type occurs.

In the prevailing systems of classification the type has been assigned to very different positions. Called a trachydolerite by Abich, as far back as $184 \mathrm{r}$, it is considered by Pilla, vom Rath, and Roth to be a trachyte, while Bucca regards it as an augite-andesite. In a former description I bestowed the name of biotite-vulsinite upon it, to indicate at the same time its chemical relation to the vulsinites and its mineralogical divergence; and this would seem to be an appropriate name, though it would best be called a biotite-latite.

MONFINAL SHOSHONOSE. II. 5, 3, 3.

Megascopic characters.-Light gray, sometimes with pinkish tinge, compact, porphyritic. Augite phenocrysts common, black or greenish-black, small prisms. Biotite phenocrysts, common and conspicuous, black, glistening, small tables. Feldspar phenocrysts few, small, white, prismatic, inconspicuous. Groundmass, fine-grained, phanerocrystalline.

Specific gravity $=2.7$ I 7 . 
Microscopic characters.-Holocrystalline to percrystalline, mediophyric, "dopatic. Phenocrysts: about 30 per cent, augite, biotite, labradorite, orthoclase. Groundmass, about 70 per cent, orthoclase, labradorite, augite, magnetite, apatite, and a colorless base, sometimes anisotropic, occasionally isotropic. Fabric trachytic.

Orthoclase, $\mathrm{Or}_{2} \mathrm{Ab}_{\mathrm{I}}$. - Phenocrysts: about 4 per cent, 0.30 to I mm., euhedral to subhedral, stout prismatic, sometimes twinned, inclusions often zonally arranged, few. Groundmass: about $3 \circ$ per cent, 0.03 to $0.1 \mathrm{~mm}$., subhedral to anhedral, slender prismatic and interstitial.

Labradorite, $\mathrm{Ab}_{2} \mathrm{An}_{3}$.-Phenocrysts: about 7 per cent, 0.50 to $2.0 \mathrm{~mm}$., euhedral to subhedral, stout prismatic, twinned, inclusions as in orthoclase. Groundmass: about 25 per cent, 0.03 to 0. Io mm., subhedral slender prismatic, twinned.

Augite.-Phenocrysts: about 8 per cent, 0.5 to $2.0 \mathrm{~mm}$., euhedral to subhedral, stout prismatic, pale greenish. Groundmass: about 5 per cent, 0.01 to $0.05 \mathrm{~mm}$., subhedral, prismatic, very pale greenish.

Biotite.-Phenocrysts: about 8 per cent, 0.5 to $2.0 \mathrm{~mm}$., subhedral, stout tabular, brown or greenish brown, usually altered on edges. Groundmass: none.

Magnetite.-Groundmass: about 5 per cent, o. or to 0 . ro $\mathrm{mm}$., anhedral, equant.

A patite.-Groundmass: about r per cent, 0.02 to $0.05 \mathrm{~mm}$., subhedral, slender prismatic.

Base.-Groundmass: about to per cent, colorless, usually indefinitely anisotropic or microfelsitic, sometimes isotropic, probably composed of quartz and orthoclase, does not gelatinize with acids.

Chemical composition and norm as on p. 88.

Type specimen from Monte Santa Croce, Auruncan District.

\section{6. 2. 2. Foglianal Vicose [Leucite-Tephrite, Viterbo Type].}

Megascopic characters. - This type in the hand specimen resembles the viterbal vulsinose and ciminose previously described so closely that it is quite impossible to distinguish them in the field. It shows the same characteristic viterboid habit, very abundant large phenocrysts of leucite in a light gray groundmass. The leucite phenocrysts are from 5 to $20 \mathrm{~mm}$. in diameter as a rule, but may run up to 50 $\mathrm{mm}$., and are highly euhedral in well-formed trapezohedra, sometimes fragmentary, either white or grayish, and often showing small dark inclusions. With these are few small black prismatic phenocrysts of augite, with still more rare prismatic phenocrysts of feldspar. The groundmass is of a rather light gray, and is either quite aphanitic or very fine-grained phanerocrystalline, only the distinction between the light and dark minerals being evident.

Microscopic characters.-In the thin section the large leucite phenocrysts exhibit the double refraction and twinned structure very clearly, and the rather numerous inclusions are seen to be of augite, magnetite, labradorite, and glass, commonly clustered toward the center. The few feldspar megaphenocrysts visible are mostly of a labradorite of about $\mathrm{Ab}_{1} \mathrm{An}_{2}$, in stout subhedral prisms, much twinned, while the phenocrysts of augite are in stout, subhedral prismoids, from 0.5 to I mm. long, often fragmentary, and of the usual pale-gray or slightly greenish color.

The groundmass in which these lie is holocrystalline typically, though a little glass base may be present in some cases. The fabric varies somewhat, but is usually 
rather granular, in some specimens rather felted, and its grain is also variable, the more granular fabrics being found in the groundmasses with the coarser grain. Microphenocrysts of leucite are common in the groundmass, in anhedral, usually rounded and occasionally irregular individuals, which show but faint double refrac" tion and carry few inclusions. Microphenocrysts of feldspar are quite common. These are soda-orthoclase, which sometimes shows a moiré appearance, and of labradorite. The relative amounts of these vary in different specimens; in some cases those of alkali-feldspar surpassing those of labradorite, as in the specimen from Monte Fogliano, while again the reverse is true, as in the rock from Monte San Antonio. The micro-groundmass shows numerous, anhedral prismoids and grains of augite and very few small, irregular grains of olivine. It is composed in large part of feldspar, apparently almost entirely a soda-orthoclase, which is sometimes in small laths with a felted fabric, and again in formless anhedra, both forms occurring together as well. There are the usual small magnetite grains and some small apatite needles. A small amount of interstitial nephelite is seen in some specimens, which is replaced in others by an equally small amount of glass base which is determinable with difficulty.

Chemical composition.-Two analyses were made of this type, neither of which has been published hitherto. With them in the table is repeated for comparison the analysis of the viterbal vulsinose from the Vico Volcano.

Chemical Composition of Foglianal Vicose [Leucite-tephrite].

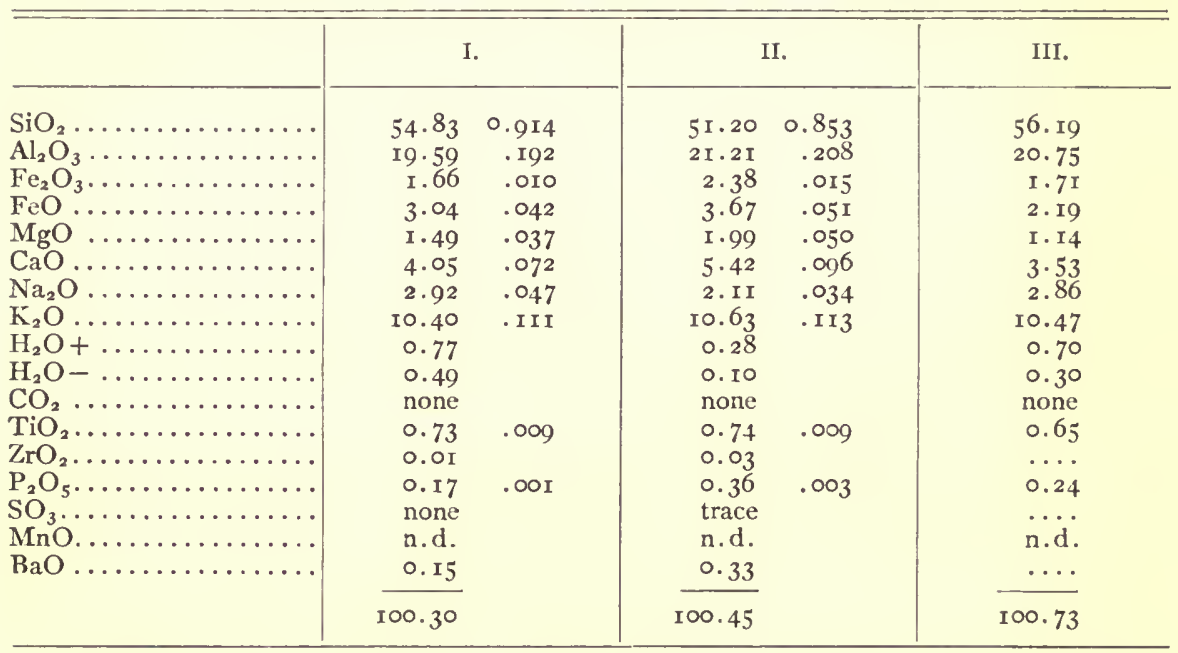

I. Foglianal vicose [leucite-tephritc]. Monte Fogliano, Vico Volcano, Ciminian District. Washington, analyst.

II. Foglianal vicose [leucite-tephrite]. Monte San Antonio, Auruncan District. Washington, analyst.

III. Viterbal vulsinose [leucite-trachyte]. Sorgente di Grignano, Vico Volcano, Ciminian District. Washington, analyst. 
Norm of $I$.

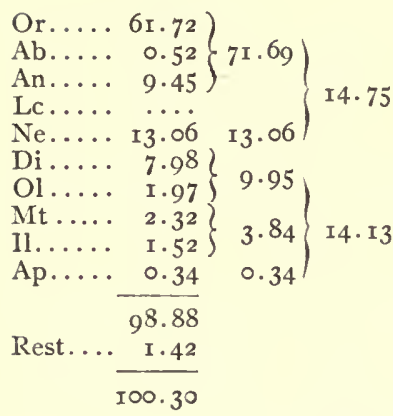

Norm of $I I$.

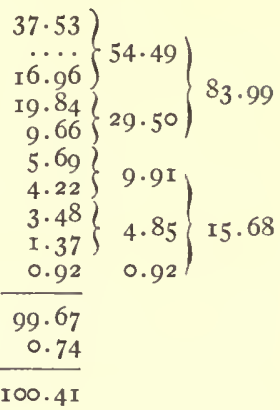

Ratios.

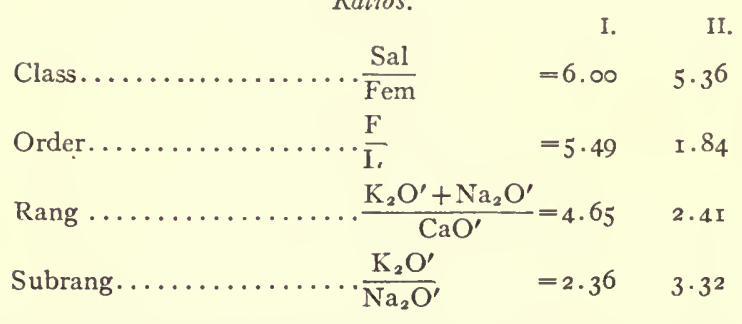

The analyses are remarkable for their figures for potash, which are among the highest recorded for this constituent. Those of foglianal vicose resemble each other closely, the chief difference being in the silica. The analyses in I and III are markedly similar, the percentages of potash, soda, and ferric and titanic oxides being almost duplicates, while those of ferrous oxide, magnesia, and lime do not differ much. But in I both silica and alumina are lower by rather more than I per cent, and it is due to this, as well as to the fact that the differences in other constituents, while slight, all work out in the same classificatory direction, that the rock represented by I falls in the dosalane class and the lendofelic order. Examination of the norms and ratios shows that both of the specimens of vicose fall well within all the classifcatory divisions, though II is rather close to the border of the lenfelic order, but not enough so to be considered transitional.

Mode.-In neither case could the mode be determined satisfactorily by Rosiwal's method, owing to the fine grain, the fabric, and the mineral composition of the microgroundmass, though the relative amounts of the phenocrysts could be easily estimated, with the results found in the formal description. On the other hand, the mode could be calculated from the norm with ease, the usual procedure being followed. The results of these calculations of the two rocks are:

\begin{tabular}{|c|c|c|c|c|}
\hline & I. & II. & & I. \\
\hline Soda-orthoclase, $\mathrm{Or}_{1} \mathrm{Ab}_{2} \ldots$ & 32.0 & I $3 \cdot 5$ & Olivine.............. & 2.0 \\
\hline Labradorite, $\mathrm{Ab}_{1} \mathrm{An}_{2} \ldots \ldots$ & II. 6 & 23.8 & Magnetite......... ... & 2.2 \\
\hline Leucite............ & 40.6 & $44 \cdot 2$ & Apatite.............. & 0.3 \\
\hline 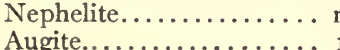 & none & I. 7 & & 20.0 \\
\hline
\end{tabular}


The two modes are closely alike in all respects, except as to the relative amounts of the two feldspars. Indeed, the divergence is so great that they should strictly be regarded as two distinct types. But considerations of the inadvisability of making the types too numerous at this stage has resulted in the final decision to throw them both together, leaving their separation to the future if the need for this is felt. It is, however, to be noted that the difference in mode shown above is evident in the thin sections, those of the Auruncan rock (II) showing more abundant labradorite than the other.

The composition of the alkali-feldspar is a striking feature, the albite molecule in each case being double that of the orthoclase. This is a decidedly unusual composition for the alkali-feldspars of the region, which usually have the orthoclase molecule predominant over that of albite. It is difficult to check this calculated composition by optical means, on account of the small size of the groundmass laths, the absence of twinning, and the frequency of formless anhedra, but such measurements as were made would seem to confirm it, and it will be remembered that the larger alkali-feldspars in these rocks show the moiré appearance which is unusual elsewhere in this region.

As compared with the norm, the only difference of importance is the replacement of normative nephelite by modal leucite, and the consequent changes in the figures for orthoclase and albite. The type may then be described as leucite salphyro-vicose.

Occurrence.-This type is a rather common one, being found in the four largest districts. In the Vulsinian District the most prominent locality is a flow above Santa Trinita, near Orvieto, but not the one whence came the specimen described by Klein.* In the Ciminian District the type is especially abundant, along with the homologous types of vulsinose and ciminose, among the products of the Vico Volcano, as in the inner north wall, the Contrada di Merlano and the Villa di Buonrespiro on the northwestern slope, and as flows from Monte Fogliano on the western. In the Sabatinian District it was found at Lagosello, northeast of Lake Bracciano. In the Auruncan District it is quite common, specimens having been obtained by me from Monte San Antonio, on the north wall, and occurring as well probably at Colle Friello, Fontanelle, and above San Martino, to judge from the descriptions of Bucca.

Name.-The name of the subrang is derived from that of the Vico Volcano, where the magma is quite abundant and where one of the most prominent types occurs. The type adjective is derived from the name of the highest point of the Vico crater, Monte Fogliano, where the type occurs.

In the prevailing systems this type has been very variously classified, according to the personal bias as to the relative importance of the salic minerals, the names leucite-trachyte, leucite-tephrite, leucite-phonolite, and leucitophyre having been bestowed upon it by different authors, and the name of leucite-basanite being also

* Klein, Neu. Jahrb., B. B. VI, 1889, p. I9. 
of possible application, on account of the olivine present. But the amounts of nephelite and olivine are so small as to be quite negligible in any system which rationally takes into account the relative amounts of the minerals, and the choice must depend on the relative amounts of, and the importance attributed to, the soda-orthoclase and the labradorite. It has been shown above that in two specimens the relations of these are inverse, and that it might be advisable to distinguish two types, which would find expression in the prevailing systems in the names leucitetrachyte and leucite-tephrite. But in view of the facts that the soda-lime feldspar is rather more prominent, even in the rock in which it is subordinate in amount, the usual greater importance given to this feldspar, and the peculiar composition of the alkali-feldspar, which approaches an albite in composition, the name of leucite-tephrite would seem to be the most appropriate for the rock. Were a new name desirable for this type, which so much resembles the viterbal vulsinose and ciminose, that of vicoite would be appropriate.

FOGLIANAL VICOSE. II. 6.2. 2.

Megascopic Characters.-Light gray, compact, highly porphyritic. Leucite phenocrysts very abundant, almost one-half of rock, 5 to $20 \mathrm{~mm}$., or larger, euhedral trapezohedra, sometimes fragmentary, white to very pale gray. Feldspar phenocrysts very few, 2 to $20 \mathrm{~mm}$., stout prismatic, colorless. Augite phenocrysts very few, I to $2 \mathrm{~mm}$., prismatic, black. Groundmass: light gray, aphanitic or rarely very fine-grained phanerocrystalline.

Microscopic characters.-Percrystalline, magnophyric, dopatic. Phenocrysts: 35 per cent, leucite, labradorite, augite, sometimes orthoclase. Groundmass: 65 per cent, microporphyritic, granular, sometimes partly felted fabric, orthoclase, labradorite, leucite, augite, olivine, magnetite, apatite, sometimes nephelite or glass base.

Soda-orthoclase, $\mathrm{Or}_{\mathrm{I}} \mathrm{Ab}_{\mathrm{I}}$ to $\mathrm{Or}_{\mathrm{I}} \mathrm{Ab}_{2}$--Phenocrysts: about 2 per cent, not always present, 5 to $20 \mathrm{~mm}$., subhedral, stout prismoidal, Carlsbad twinning, few inclusions. Groundmass: I5 to 30 per cent, 0.02 to $0.20 \mathrm{~mm}$., subhedral to anhedral, in part tabular, in part as interstitial areas.

Labradorite, $\mathrm{Ab}_{\mathrm{I}} \mathrm{An}_{2}$.-Megaphenocrysts: about 3 per cent, 5 to $20 \mathrm{~mm}$., subhedral, stout prismoidal, twinned, inclusions few. Microphenocrysts: from 5 to 20 per cent, 0.1 to $0.5 \mathrm{~mm}$., subhedral to anhedral, thick tabular, twinned. Microgroundmass: about 5 per cent, not always present, 0.02 to $0.0 .10 \mathrm{~mm}$., anhedral, tabular.

Leucite.-Megaphenocrysts: about 30 per cent, 5 to $20 \mathrm{~mm}$. or more, euhedral, equant trapezohedra, often fragmentary, twinned, inclusions common of augite, labradorite, magnetite, and glass, usually centrally arranged. Microphenocrysts: about ro per cent, 0.05 to $0.50 \mathrm{~mm}$. subhedral to anhedral, equant spheroidal, sometimes irregular, faint twinning, inclusions few.

Nephelite.-Groundmass: 5 per cent to none, anhedral, formless, interstitial areas.

A ugite.-Phenocrysts: about 2 per cent, 0.5 to $2.0 \mathrm{~mm}$., subhedral, stout prismoidal, gray to pale greenish-yellow, non-pleochroic, inclusions rare. Groundmass: about 10 per cent, 0.05 to $0.20 \mathrm{~mm}$., subhedral to anhedral, prismoidal to equant and irregular, colorless or pale gray.

Olivine.-Groundmass: about 3 per cent, 0.02 to $0.10 \mathrm{~mm}$., anhedral, equant, colorless.

Magnetite.-Groundmass: about 2 per cent, 0.02 to $0.05 \mathrm{~mm}$., anhedral, equant.

A patite.-Groundmass: about I per cent, $0.0 \mathrm{r}$ to $0.05 \mathrm{~mm}$., subhedral, thin prismoidal.

Glass.-Usually none, sometimes up to 5 per cent, colorless, difficult to detect.

Chemical composition and norm as on p. 92.

Type specimens from Convento di Sant'Angelo, Monte Fogliano, Vico Volcano, Ciminian District, and from Monte San Antonio, Auruncan District. 


\section{6. 2. 2. Bagnoreal Vicose [Leucite-Tephrite, Bagnorea Type].}

Megascopic characters. - In the hand specimen these rocks closely resemble the bagnoreal ciminose already described. They are medium gray, varying somewhat in different specimens, but never becoming very light or very dark. While distinctly porphyritic, phenocrysts are few and inconspicuous. These are mostly of leucite, in subhedral crystals, from 3 to $10 \mathrm{~mm}$. in diameter, usually of a very pale-gray color, often with a slightly yellowish tinge. Small prismatic phenocrysts of black augite are still more rare. In some specimens are one or two rounded patches (up to $5 \mathrm{~cm}$. in diameter), of medium-grained aggregates of small leucite and augite grains, apparently early solidified segregations from the magma (enclaves homeogènes). The groundmass is distinctly phanerocrystalline and fine-grained, the separate particles of light and dark minerals clearly visible to the naked eye.

Microscopic characters.-Studied in thin section the rare leucite phenocrysts show more or less irregular outlines, the crystal form not having been well developed. The double refraction and twinning are strongly marked, and inclusions are not common. The subhedrally prismatic augite phenocrysts are of the usual pale-gray color, though in some specimens there is a tendency to zonal growth, as shown by a slight deepening of the greenish tint toward the center or by progressive extinctions.

The groundmass is holocrystalline in nearly all the specimens examined, the fabric is intersertal, and it is composed in great part of leucite, partly in the form of small, subhedral spheroids, and partly in quite irregular anhedra. All these are clear and carry few if any inclusions. With these leucites are many small feldspar laths, the majority being of a twinned labradorite about $\mathrm{Ab}_{2} \mathrm{An}_{3}$, with fewer of alkali-feldspar, which is also present to some extent as an interstitial cement in patches. The arrangement of these feldspar laths is diverse, producing an intersertal fabric. Small augites are also abundant in stout subhedral prismoids, often so short as to be almost equant. The gray color of this is also slightly more greenish than is usually true of the rocks of the region, though the absence of pleochroism indicates that it does not carry any of the ægirite molecule. Small magnetite grains and apatite prisms are present, both in rather greater amount than is usually the case in similar rocks elsewhere in the region, but no olivine could be detected. In some of the specimens there is some colorless nephelite as an interstitial base, the last product of solidification, while in a few this is partly replaced by a colorless glass, the amount of which, however, is never great.

Chemical composition.-Of this type two hitherto unpublished analyses are given. In III is found an earlier analysis of the same specimen as that used for II, in which $\mathrm{MgO}$ was determined from loss, and with no determinations of $\mathrm{TiO}_{2}$ and $\mathrm{P}_{2} \mathrm{O}_{5}$. As this was unsatisfactory, all the main constituents from silica to lime were redetermined on another portion of the specimen, the determinations of the alkalis being accepted as correct; and these, with the additional determinations of the minor constituents, form the analysis in II. 
Chemical Composition of Bagnoreal Vicose [Leucite-tephrite].

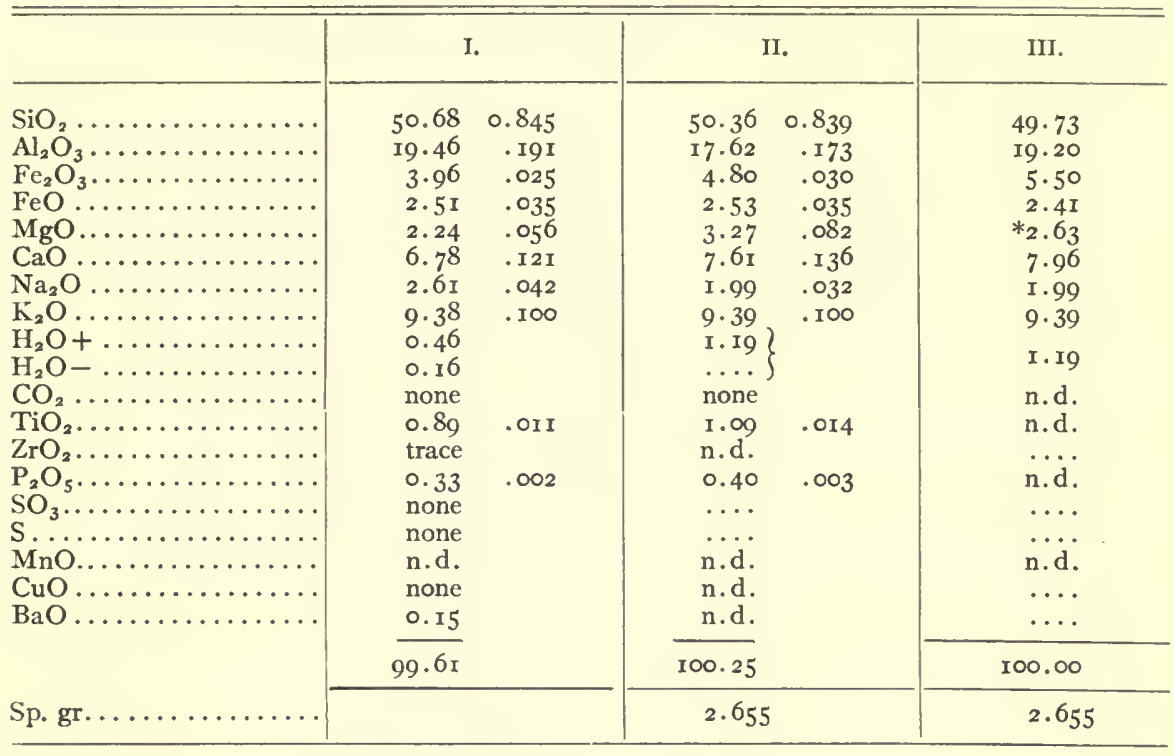

* $\mathrm{MgO}$ by difference.

I. Bagnoreal vicose [leucite-tephrite]. Poggio Cotognola, near Bracciano, Sabatinian District. Washington, analyst.

II. Bagnoreal vicose [leucite-tephrite]. Madonna del Riposo, below Bracciano, Sabatinian District. Washington, analyst.

III. Bagnoreal vicose [leucite-tephrite]. Madonna del Riposo, below Bracciano, Sabatinian District. Washington, analyst. Jour. Geol., V, 1897, p. 49.

$$
\text { Norm of } I \text {. }
$$

Or..........39.48

An............ 13.62$\} 53.10\}$

$\left.\left.\begin{array}{l}\text { An.........13.62 } \\ \text { Lc..........12.62 } \\ \text { Ne.......11.93 }\end{array}\right\} \begin{array}{l}53.10 \\ 24.55\end{array}\right\} 77.65$

Di..........12.10

Mt........ 5.80

Il $\ldots \ldots \ldots$ I. I. 52$\} 7.32\} 21.19$

$\mathrm{Hm}$.......... 0.00

Ap........ 0.73

$$
\overline{98.84}
$$

Rest...... 0.77

$99.6 \mathrm{I}$
Wo.........1.04 1 . 13.14

Norm of II.

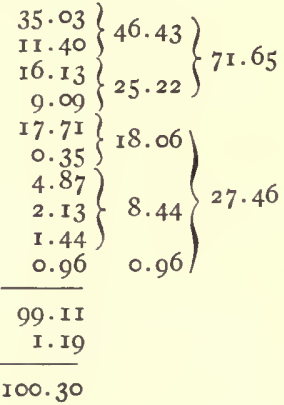

Ratios.

$$
\text { I. II. }
$$

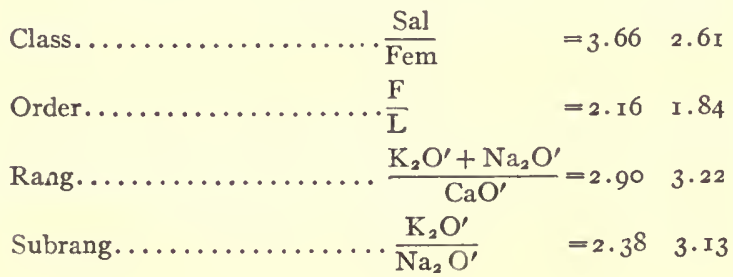


The two analyses I and II are very closely alike, especially in silica, ferrous oxide, and potash. The alumina in $I$ is the higher by 2 per cent, and as this is accompanied by I per cent less of magnesia, the suspicion may present itself that some of the magnesia has been thrown down with the alumina. This analysis, however, is the later of the two, and especial attention was paid at the time to this very point. Furthermore, it will be observed that the general character of $I$ in other respects is more salic than II, as shown by the slightly higher soda and lower ferric oxide, lime, titanium, and phosphoric oxide; and these chemical differences are in harmony with the rocks themselves. The Cotognola rock (I) is very notably lighter in color, and the sections show somewhat less alferric and femic minerals than that from Madonna del Riposo (II).

The analyses in themselves call for no special comment. Silica is lower than in any rock so far described here, and while potash is high, it is distinctly less so than in any previously described types of vicose. The magmatic positions shown by the norm are in most cases well within the limits, except the ordinal position of II, which approaches rather near that of the lenfelic order, but neither rock can be justly regarded as transitional.

On the basis of the analysis shown in III the rock from Madonna del Riposo has been assigned* to the subrang braccianose, II. 7.2.2. This was correct as based on the analytical data then available, but the new analysis shows that the true position is rather in vicose, II. 6. 2. 2, though, as we have seen above, somewhat near the border of the division to which it was first assigned. The change is brought about by several factors, each of slight moment in itself, but all acting in the same direction, the increase in the figures for silica and magnesia, the decrease in alumina and lime, and the additional determinations of titanium and phosphoric oxides.

Mode.-The mode of the Cotognola rock was calculated from the norm by readjustment of the mineral molecules, in the usual way. It was somewhat difficult to distinguish the colorless groundmass minerals with sufficient accuracy, so that the Rosiwal method was not applied, though a rough estimate of the leucite present was undertaken to use in the calculation. This amounted to 40 per cent by volume. As the Riposo rock is not holocrystalline, containing about 5 per cent of glass, its mode was not calculated, but it will resemble the other closely.

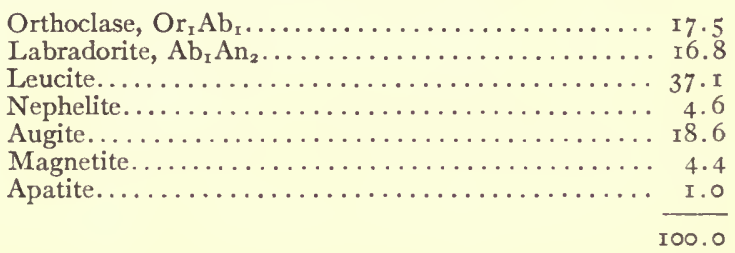

This mode shows the distinctly more alferric character of the type, indicated in the analysis by the lower silica and the higher bivalent metal oxides. The amounts

* Washington, Prof. Paper U. S. Geol. Surv. No. r4, rgo3, p. 305. 
of alkali and soda-lime feldspars are almost identical, leading to the uncertainty as to the classification under prevailing systems, though the difference in habit and prominence of the two in the groundmass reduces this to some extent.

As in so many of the preceding cases, the modal divergence from the norm is brought about largely by the increase in leucite and decrease in orthoclase and nephelite, making leucite the critical mineral. The type may therefore be described, as in the case of the two preceding, as leucite salphyro-vicose.

Occurrence.-This type seems to be most abundant in the Sabatinian District, typical localities being flows at Madonna del Riposo, below the town of Bracciano, and at a quarry along the railroad below Poggio Cotognola, southwest of Bracciano. Some flows at Monte Bisenzo, on the south shore of Lake Bolsena, in the Vulsinian District, may also be referred here, and undoubtedly belong to the subrang of vicose, though most of them are so poor in phenocrysts as to belong rather to the aphyric orvietal type to be described later.

Name.-Both the subrang and type names have already been discussed. In the prevailing classifications this type must be considered as a leucite-tephrite, in view of the mode and texture, since although orthoclase and labradorite are present in almost equal amounts, the latter is the more prominent in the sections and is usually given more weight in classification.

BAGNOREAL VICOSE. II, 6. 2. 2.

Megascopic characters.-Medium gray, compact, slightly porphyritic. Leucite phenocrysts few, 3 to xo mm., grayish, not very conspicuous. Augite phenocrysts rare, 0.5 to $2 \mathrm{~mm}$., prismatic, black. Groundmass: medium gray, fine-grained, phanerocrystalline.

Microscopic characters.-Holocrystalline, magnophyric, perpatic. Phenocrysts: ro per cent or less; leucite, augite. Groundmass: 90 per cent or more, holocrystalline or percrystalline, intersertal fabric, leucite, orthoclase, labradorite, augite, magnetite, apatite, sometimes nephelite or glass.

Orthoclase, $\mathrm{Or}_{\mathrm{I}} \mathrm{Ab}_{\mathrm{r}}$.-Phenocrysts: none. Groundmass: about $\mathrm{x} 8$ per cent, in part $\mathrm{O}$. $\mathrm{I}$ to $0.5 \mathrm{~mm}$., subhedral, tabular, with diverse arrangement, in part as anhedral, formless patches of interstitial cement.

Labradorite, $\mathrm{Ab}_{1} \mathrm{An}_{2}$.-Phenocrysts: none. Groundmass: about $\mathrm{x} 7$ per cent, $0 . \mathrm{x}$ to 0.5 $\mathrm{mm}$., thin tabular, twinned, arrangement diverse.

Leucite.-Phenocrysts: about 5 per cent, 3 to ro mm., subhedral to anhedral, equant to irregular, twinned, inclusions rare. Groundmass: about 30 per cent, o. x to x.o mm., anhedral, equant and irregular, few inclusions.

Nephelite.-Groundmass: 5 per cent to none, anhedral, as interstitial cement.

Augite.-Phenocrysts: about 3 per cent, 0.5 to $2.0 \mathrm{~mm}$., subhedral to anhedral, prismatic and fragmentary, pale gray or greenish, non-pleochroic, inclusions few. Groundmass: about $x_{5}$ per cent, 0.1 to $0.5 \mathrm{~mm}$., subhedral to anhedral, prismatic to equant, pale gray or very pale greenish.

Magnetite.-Groundmass: about 4 per cent, 0.02 to $0.05 \mathrm{~mm}$., anhedral, equant to irregular.

A patite.-Groundmass: about $\mathrm{x}$ per cent, 0.05 to $0 . x 0 \mathrm{~mm}$., subhedral, thin prismatic. Glass.-Groundmass: 5 per cent to none, colorless, difficult to detect. 
Chemical composition and norm as on p. 97.

Type specimens from Poggio Cotognola and Madonna del Riposo, near Bracciano, Sabatinian District.

\section{I1. 6. 2. 2. Orvietal Vicose [Leucite $=$ Tephrite, Orvieto Type].}

Megascopic characters. - In the hand specimen these rocks are quite indistinguishable from the orvietal auruncose described above. They are rather light gray basalts, almost, if not entirely, aphyric, the only phenocrysts being small prisms of dark-green augite, and even these being wanting in most specimens, and when present excessively scarce. The grain is distinctly phanerocrystalline, but very fine, a lens being needed in most cases to distinguish between the light and dark minerals.

Microscopic characters.-In thin section the texture is seen to be practically holocrystalline, though a very minute amount of glass may be sometimes present. The fabric is an intersertal one, due to the divergent arrangement of the labradorite laths. This labradorite, which gives extinction angles corresponding to about $\mathrm{Ab}_{\mathrm{I}} \mathrm{An}_{\mathrm{I}}$, is in thin plates, tabular parallel to $b$ (ого), and almost always multiply twinned. There are some tables of alkali-feldspar as well, but these are few, and for the most part this mineral is anhedral and interstitial between the other components. Leucite is abundant, rarely in subhedral spheroids, and usually in irregular anhedral patches, and later than the labradorite. Its double refraction is rather weak, and inclusions of the usual kind are not common and are seldom regularly arranged. There is much augite, in subhedral or anhedral prismoids and grains, of a greenish-gray color and non-pleochroic. This augite is often accompanied on the ends and sides by a later growth of a brown, pleochroic hornblende, which also forms separate anhedral individuals. The amount of this mineral, which may be referred to barkevikite, is very small. A little olivine is also seen, in small, anhedral grains, which is to be distinguished from the augite by its lack of color, as well as by its higher refractive index and birefringence. Grains of magnetite and small prisms of apatite are present in small quantity. There is also a very small amount of interstitial nephelite, with possibly a very little glass in some specimens; but the rock typically is holocrystalline.

From the description just given it is clear that, with the exception of the presence of barkevikite, whose amount is so small as to be negligible in defining the type, this rock is essentially similar to the groundmass of the bagnoreal type described above. It may be regarded as the aphyric end of a textural series of types, of which the viterbal is the most porphyritic, and the bagnoreal intermediate.

Chemical composition.-The previously published analysis of this type is repeated here, with a number of additional determinations made recently. The present statement contains a correction in the amount of $\mathrm{Na}_{2} \mathrm{O}$, as it was found, in going over the figures in the laboratory notebook, that a slip had been made in subtracting the weight of the $\mathrm{KCl}$ from that of the mixed $\mathrm{NaCl}+\mathrm{KCl}$, the weight of $\mathrm{NaCl}$ being given as 0.05673 grm., instead of 0.04673 grm., the true one. 
Chemical Composition of Orvietal Vicose [Leucite-tephrite].

\begin{tabular}{|c|c|c|c|c|c|}
\hline \multirow[b]{2}{*}{ 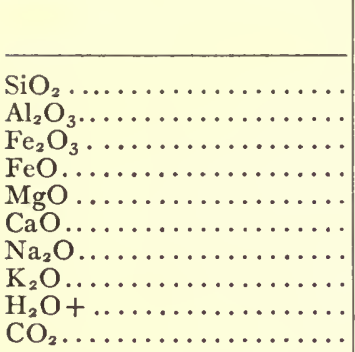 } & \multicolumn{2}{|r|}{ I. } & \multirow[b]{2}{*}{ 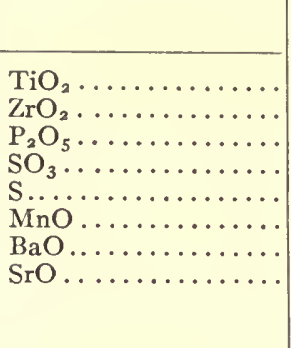 } & \multicolumn{2}{|c|}{ I. } \\
\hline & $\begin{array}{r}50.24 \\
\text { I. } 43 \\
2.54 \\
5.68 \\
3.65 \\
7.83 \\
* 2.45 \\
7 \cdot 45 \\
\text { o. } 36 \\
\text { none }\end{array}$ & $\begin{array}{r}0.838 \\
.181 \\
.016 \\
.079 \\
.091 \\
.139 \\
.040 \\
.080\end{array}$ & & $\begin{array}{l}\text { I. I9 } \\
\text { none } \\
0.47 \\
\text { none } \\
\text { none } \\
\text { n.d. } \\
0.29 \\
\text { trace } \\
\text { I00.58 }\end{array}$ & .003 \\
\hline
\end{tabular}

* Former figure $=2.07$.

I. Orvietal vicose [leucite-tephrite]. Monte Cavallo, near Orvieto, Vulsinian District. Washington, analyst. Jour. Geol., V, I897, p. 370.

\section{Norm.}

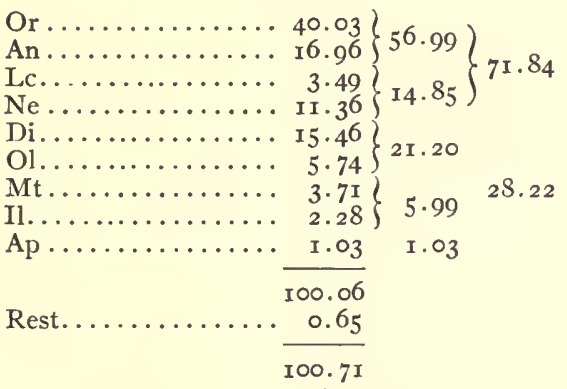

Ratios.
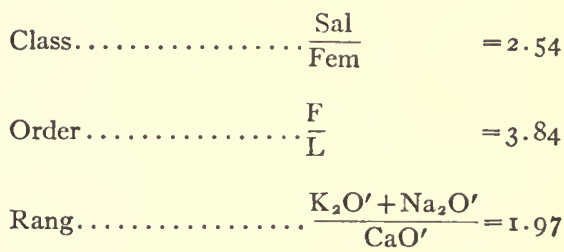

Subrang............. $\frac{\mathrm{K}_{2} \mathrm{O}^{\prime}}{\mathrm{Na}_{2} \mathrm{O}^{\prime}} \quad=2.00$

The analysis resembles that of the bagnoreal type, though potash is here somewhat lower, and the general character slightly more femic. It will be noted that the correction of the figure for $\mathrm{Na}_{2} \mathrm{O}$ not only lowers the previous summation, which would be IOI.03 with the additional determination of $\mathrm{BaO}$, to a satisfactory figure, but also carries the magmatic position from sodipotassic borolanose (II. 6 . 2. 3), where the type was formerly reckoned as belonging,* to the dopotassic subrang vicose (II. 6. 2. 2), and thus in accord with the numerous other similar leucitic rocks of the region, which are all dopotassic.

Mode.-As was the case with the groundmass of the preceding type, this rock did not lend itself well to measurement of the mode under the microscope, though a rough estimate was made to control the calculation of the mode from the norm, which was carried out as usual. In estimating the barkevikite this mineral was assumed to have the composition of the similar hornblende in the pulaskose (sodalite-syenite) of Square Butte. $†$

* Washington. Prof. Paper U. S. Geol. Surv. No. 14, 1903, p. 297. It was remarked here that it is "near subrang 2 of essexase," that is, vicose.

† Lindgren and Melville, Am. Jour. Sci., XIY, 1893, p. 292. Cf. Pirsson, Bull. U. S. Geol. Surv. No. 237, Iço5, p. 66 . 


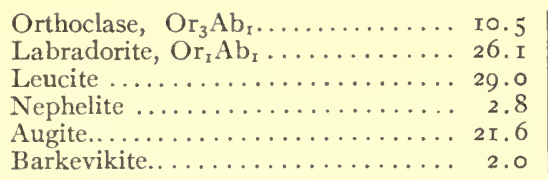

Olivine.................. 5.0

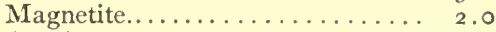

Apatite................. r.

I00.0

In this mode the decidedly alferric character and the predominance of labradorite over orthoclase are marked. As compared with the viterbal and bagnoreal types of vicose the alkali-feldspar contains a much smaller proportion of the albite molecule, while the labradorite is distinctly more sodic, being on the border of andesine. In these respects it corresponds very closely with the mode of orvietal auruncose described above.

As compared with the norm it is clear that the only differences of serious importance are, as usual, those involved in the formation of leucite, much of the normative orthoclase being used for this, and the nephelite, changed to albite, entering into the feldspars. The type may therefore be described as leucite intersertiaphyro-vicose.

Occurrence.-So far as known orvietal vicose occurs only in the Vulsinian District. It is abundant near the town of Orvieto, especially to the south of this, as at Monte Cavallo and Porano, where it forms extensive flows. It also makes up the main part of the hill of Monte Bisenzo on the southwest shore of Lake Bolsena.

Name.-The derivation of the subrang name is discussed above. That of the type is based on the name of the town of Orvieto, near which it occurs in abundance.

In the prevailing systems of classification the name of leucite-tephrite, which was applied to the type in a previous description, is the appropriate one, on account of the quantitative predominance of labradorite over orthoclase, as well as its greater conspicuousness in the thin section. The amount of olivine is so small that its presence may be disregarded, and the name of leucite-basanite is unwarranted.

ORVIETAL VICOSE. 11. 6. 2. 2.

Megascopic characters.-Medium gray, compact, aphyric, very fine-grained, phanerocrystalline.

Microscopic characters.--Holocrystalline, microporphyritic, intersertal fabric. Microphenocrysts: about 50 per cent, leucite, labradorite, orthoclase, augite. Microgroundmass: about $5^{\circ}$ per cent, augite, orthoclase, olivine, barkevikite, nephelite, magnetite, apatite.

Orthoclase, $\mathrm{Or}_{3} \mathrm{Ab}_{1}$.-Microphenocrysts: about 3 per cent, $0 . \mathrm{x}$ to $0.5 \mathrm{~mm}$., subhedral, thin tabular, twinning uncommon, arrangement diverse. Microgroundmass: about 8 per cent, anhedral, as interstitial areas.

Labradorite, $\mathrm{Ab}_{\mathrm{I}} \mathrm{An}_{\mathrm{I}}$.-Microphenocrysts: about 25 per cent, $0 . \mathrm{x}$ to $0.5 \mathrm{~mm}$., subhedral thin, tabular, twinning common, arrangement diverse.

Leucite.-Microphenocrysts: about 30 per cent, O. I to I.o mm., anhedral, equant, more often irregular, often incloses the feldspar tables, inclusions few.

Nephelite.-Microgroundmass: about 2 per cent, anhedral, formless, interstitial areas. Not always present. 
Augite.-Microphenocrysts and microgroundmass: about 20 per cent, o. I to $0.5 \mathrm{~mm}$., subhedral to anhedral, stout prismatic and equant, pale greenish-gray, non-pleochroic.

Olivine.-Microgroundmass: about 5 per cent, 0.08 to 0 . ro mm., subhedral to anhedral, equant, colorless.

Barkevikite-Microgroundmass; about 2 per cent, 0.02 to $0.05 \mathrm{~mm}$., anhedral, as interstitial areas or fringing the augites, light brown.

Magnetite.-Microgroundmass: about 2 per cent, 0.02 to $0.05 \mathrm{~mm}$., anhedral, equant.

A patite.-Microgroundmass: about I per cent, subhedral, prismatic.

Chemical composition and norm as on p. ror.

Type specimen from Monte Cavallo, south of Orvieto, Vulsinian District.

\section{7. 2. 2. Vesbal Braccianose [Leucite-Tephrite, Vesuvius Type].}

Megascopic characters.-Rocks of this type are of a general dark-gray color, speckled with numerous small white spots. They are highly porphyritic, the very great majority of the phenocrysts being of leucite, and with small and almost negligible numbers of phenocrysts of augite and sometimes of olivine or biotite. The leucite phenocrysts vary in diameter from $\mathrm{x}$ to $3 \mathrm{~mm}$., being seldom over the latter. They are for the most part spheroids, giving round sections, but are also well-formed trapezohedra. In color they are usually pale gray, rather than clear white, so that they are not as strikingly conspicuous as might be expected, though always clearly discernible. The few augite phenocrysts are dark green, in small, stout prismoids and grains, seldom over $3 \mathrm{~mm}$. long. The more uncommon olivine phenocrysts are of similar-sized, yellowish-green grains, and the still rarer biotites form small black tables. The groundmass is a dark gray, compact and aphanitic, and in the field these rocks would be called leucite melaphyres. Most of the specimens are more or less vesicular.

Microscopic characters. - In thin section the leucite phenocrysts, which form nearly one-half of the rock volume, present mostly rounded outlines, with occasional crystal planes. They are apt to be cracked, or sometimes in clusters of several closely juxtaposed individuals. Double refraction is not well marked, as a rule, and inclusions are generally few and irregularly arranged. An occasional stout and prismatic labradorite phenocryst is seen, though these are seldom if ever visible in the hand specimen. The augite phenocrysts are in stout prismoids, usually much broken and often anhedral, of a slightly yellowish-brown tinge of gray. They carry few inclusions, and these mostly of magnetite. The rare, anhedral, generally fragmentary olivine phenocrysts call for no comment, nor do the still rarer tables of brownish biotite, which show the common alteration phenomena.

The groundmass in which these lie is usually holocrystalline, but a trifling amount of glass is visible in some instances. The fabric is xenomorphic granular, somewhat intersertal through the development and diverse arrangement of the labradorite, and may be briefly described as subintersertal. It consists in large part of pale-gray, slightly brownish augite, sometimes showing a zonal structure, in irregular anhedral grains, few of which assume a distinctly prismatic habit. Tables of labradorite, which give rise to lath-shaped sections, are fairly numerous, their length 
often reaching I mm., but usually much under this. They are always multiply twinned, with extinction angles which vary somewhat, but which indicate an average composition of about $\mathrm{Ab}_{2} \mathrm{An}_{3}$. As stated above, their arrangement is divergent, so as to give rise to an approach to a true intersertal fabric. Alkali-feldspar seems to be quite absent, but some small leucite anhedra are found in the groundmass. Small olivine grains, usually quite anhedral, but occasionally with crystal planes, are scattered through the groundmass, but the total amount of this mineral is always small and quite negligible for classificatory purposes. A little residual nephelite base is present in most cases, its place being taken in some specimens by glass.

Chemical composition.-An analysis of a specimen of this type from the flow of I872 of Mount Vesuvius, collected below the Observatory, is given below in I, having been previously published, but without petrographical description. The position assigned the rock at that time, namely, in vesuvose, II. 8. 2. 2, was erroneous through inadvertence, not on account of error in the analysis or in calculating the norm. As was pointed out later,* the analysis should have been placed in the subrang II. 7. 2. 2. With it is also given an analysis of the lava of the eruption of I89I-93, which probably belongs to the same type, though the description of Matteucci† leaves this somewhat in doubt.

Chemical Composition of Vesbal Braccianose [Leucite-tephrite].

\begin{tabular}{|c|c|c|c|c|c|c|c|}
\hline & I & I. & II. & & I. & & II. \\
\hline 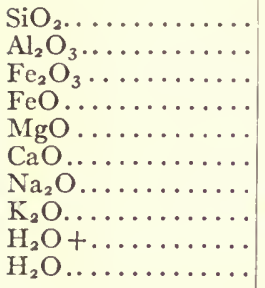 & $\begin{array}{r}47.65 \\
\text { I } 8.13 \\
2.63 \\
6.48 \\
4.19 \\
9.01 \\
2.78 \\
7.47 \\
0.13 \\
\left.\begin{array}{l}0.11 \\
2\end{array}\right\}\end{array}$ & $\begin{array}{r}0.794 \\
.178 \\
.017 \\
.090 \\
.105 \\
.161 \\
.045 \\
.080\end{array}$ & $\begin{array}{r}48.99 \\
\text { I9.82 } \\
2.59 \\
5.26 \\
2.82 \\
8.13 \\
3.17 \\
9.06 \\
\text { n.d. }\end{array}$ & 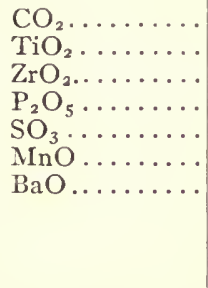 & $\begin{array}{l}\text { none } \\
\text { I. I3 } \\
0.02 \\
0.50 \\
\text { trace } \\
\text { n.d. } \\
0.24 \\
\text { I00.47 }\end{array}$ & $\begin{array}{r}0.014 \\
.004\end{array}$ & $\begin{array}{c}\ldots . \\
\ldots \ldots \\
\cdots \\
0.33 \\
\cdots \cdots \\
\cdots \cdots \\
\ldots \ldots \\
100.17\end{array}$ \\
\hline
\end{tabular}

I. Vesbal braccianose [leucite-tephrite]. Lava of 1872 , below Observatory, Mount Vesuvius. Cf. Washington, Prof. Paper U. S. G. S. No. I4, I903, p. 307.

II. Vesbal (?) braccianose [leucite-tephrite]. Lava of I89I-93. Atrio del Cavallo, Mount Vesuvius. Mrha, analyst. F. Becke, Tsch. Min. Pet. Mitth., XVIII, r898, p. 94. Norm of $I$.

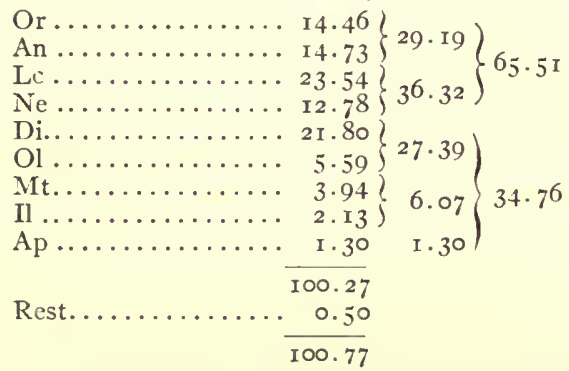

Ratios of $I$.
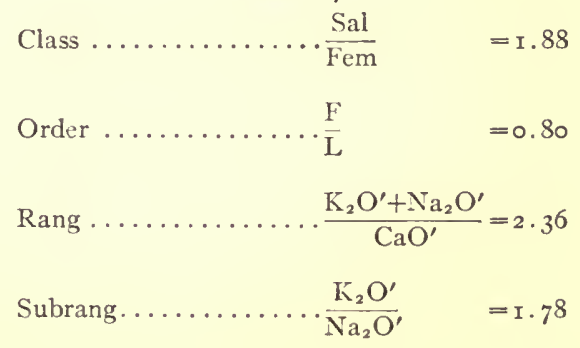

* Washington, Prof. Paper U. S. Geol. Surv. No. 28, 1904, p. 68.

† R. V. Matteucci. Tscherm. Min. Pet. Mitth., XV, 1895, p. 342. 
The analysis (I) resembles closely many of the earlier analyses of Vesuvian lavas. Compared with the analyses given in the preceding pages it is marked by its low silica content, which is 3 per cent less than in the types of vicose. Concomitantly with this decrease in silica there is an increase in the amount of lime, though the other constituents are not notably affected. The analysis of the later flow resembles the former in a general way, though potash is decidedly higher. The higher alumina is to be attributed in part to the non-determination of $\mathrm{TiO}_{2}$, which would be included in this, and also possibly in part to incomplete separation of the magnesia, as the amount of this last is rather low.

Mode.-In case of this type, as in some of the preceding, the character of the groundmass did not permit of satisfactory measurement by Rosiwal's method, the relative amount of leucite phenocrysts being the only quantitative relation which could be determined with precision. The mode was calculated from the norm on the assumptions that no orthoclase was present and that all the potash belongs to leucite, that the normative olivine corresponds with the modal, that the augite has the composition of that of Ticchiena (p. r34), and that the plagioclase has the composition $\mathrm{Ab}_{2} \mathrm{An}_{3}$. The results of this calculation are:

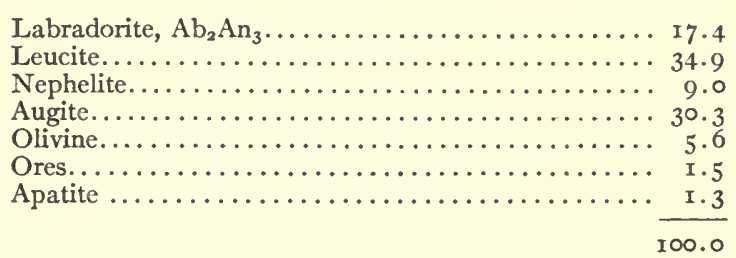

The amount of leucite shown corresponds well with that determined optically, namely, 40 per cent by volume, and in general the mode above agrees with the appearance of the thin section. Only the amount of nephelite seems to be high. The figure for this was that obtained by the usual equations involving the total soda and the silica available after formation of leucite, augite, olivine, and the anorthite of plagioclase. These give an amount of albite molecule exactly right to satisfy the composition of the plagioclase determined optically, that is, $\mathrm{Ab}=0.0 \mathrm{I}_{3}, \mathrm{An}=0.038$. Any notable change in the figure for nephelite will involve very serious modification of the plagioclase composition, rendering it an andesine, which can not be considered in view of the optical determinations, and will also concomitantly lead to increase in the amount of olivine and decrease in that of augite, which are also inadmissible. The amount of nephelite is readily underestimated by the eye in such groundmasses, and a test of the rock powder with very dilute nitric acid, according to the method suggested by Pirsson,* gave abundant gelatinous silica, thus proving its presence in considerable amount.

Occurrence.-This type is abundant in the Campanian District, many of the flows of Vesuvius belonging to it. Among those which I have examined may be mentioned those of 1822 (above Cerasiello) and ${ }_{1} 872$ (below the Observatory),

* L. V. Pirsson, Am. Jour. Sci., II, 1896, p. 142. 
while the descriptions of Fuchs suggest that flows of $1731,1754, x 767,1779,1786$, I $802,1810,1855,1858$, and 1867 are also of this type. The type seems also to occur at Monte Somma, but to a more limited extent. Outside of the Campanian District these rocks seem to be rare, and the only specimen in my possession which may probably be referred here is the lava of Poggio Romolo, south of Lake Bolsena.

Name.-The name of the subrang is derived from the lake and town of Bracciano, the chief geographical features of the Sabatinian District, in the southern part of which this magma is very abundant. The type name is derived from Vesbius, an old Latin name of Vesuvius.

In the prevailing classifications the type should be regarded as a leucite-tephrite, since the amount of olivine is so small that the name of leucite-basanite often given it is not justified if regard is paid to quantitative relations.

VESBAL BRACCIANOSE. II. 7.2. 2 .

Megascopic characters. -Dark gray, sprinkled with small white spots. Compact to vesicular, highly porphyritic. Leucite phenocrysts very abundant, I to $3 \mathrm{~mm}$., round, white or pale gray, sometimes not very conspicuous. Augite phenocrysts very few, I to $3 \mathrm{~mm}$. long, prismatic black or dark green. Olivine phenocrysts very rare, not essential, I to $2 \mathrm{~mm}$., equant, yellow. Biotite phenocrysts very rare, not essential, I to $3 \mathrm{~mm}$., tabular, brown. Groundmass, rather dark gray, aphanitic.

Microscopic characters.-Holocrystalline, mediophyric, sempatic. Phenocrysts: about 40 per cent, leucite, augite, sometimes olivine and biotite. Groundmass: about 60 per cent, holocrystalline, somewhat intersertal fabric, augite, labradorite, nephelite, leucite, olivine, magnetite, apatite.

Labradorite, $\mathrm{Ab}_{2} \mathrm{An}_{3}$. - Phenocrysts: 2 to o per cent, I to $2 \mathrm{~mm}$., subhedral, stout prismatic, twinned, few inclusions. Groundmass: about 15 per cent, 0.05 to $0.50 \mathrm{~mm}$., thin prismatic or tabular, much twinned, arrangement diverse.

Leucite.-Phenocrysts: about 35 per cent, 0.5 to $3.0 \mathrm{~mm}$., subhedral to anhedral, equant to irregular, sometimes in clusters, inclusions few. Groundmass: about 2 per cent, 0.05 to 0 . 10 $\mathrm{mm}$., anhedral, equant and irregular.

Nephelite.-Groundmass: 5 to ro per cent, anhedral, as interstitial cement.

A ugite.-Phenocrysts: about 5 per cent, often less, 0.5 to $3.0 \mathrm{~mm}$., subhedral to anhedral, prismatic or fragmentary, pale yellowish-brown or yellowish-green, uonpleochroic, inclusions few. Groundmass: about 25 per cent, 0.05 to $0.20 \mathrm{~mm}$., anhedral, prismatic, fusiform, equant, pale greenish- or yellowish-gray, arrangement generally diverse, sometimes tangential about the leucite phenocrysts, no inclusions.

Biotite.-Phenocrysts: 2 to o per cent, 0.5 to $3.0 \mathrm{~mm}$., subhedral, tabular, brown, usually altered.

Olivine.-Phenocrysts: 2 to $\circ$ per cent, 0.5 to $2.0 \mathrm{~mm}$., subhedral to anhedral, equant to irregular, colorless. Groundmass: about 3 per cent, not always present, 0.05 to 0 . 10 $\mathrm{mm}$., anhedral, equant, colorless. irregular.

Magnetite.-Groundmass: about 2 per cent, 0.02 to $0.05 \mathrm{~mm}$., anhedral, equant, and

A patite-Groundmass: about I per cent, 0.05 to $0.20 \mathrm{~mm}$., subhedral, prismatic.

Chemical composition and norm as on p. ro4.

Type specimen from flow of 1872 , below Observatory, Mount Vesuvius, Campanian District. 


\section{7. 2. 2. Sommal Braccianose [Leucite-Tephrite, Somma Type].}

Megascopic characters.-Like the preceding type, this is highly porphyritic. The phenocrysts are of both leucite and augite, present in about equal amount and together making up about 40 per cent or so of the rock volume. Those of leucite are from $\mathrm{I}$ to $4 \mathrm{~mm}$. in diameter, rounded, and anhedral, with only occasional crystal planes. Their color is usually gray, so that they do not stand out prominently against the groundmass. The phenocrysts of augite are about the same size, usually subhedral and with crystal planes, especially those of the prisms and pinacoids. In form they tend to be equant rather than prismatic, giving square or only slightly oblong and angular sections. They are very dark green in color, almost black. An occasional yellowish-green grain of olivine is seen, but the amount of this mineral is negligible. The groundmass is dark gray and aphanitic. In the field the type would be called a leucite-augite-melaphyre.

Microscopic characters. - The thin sections of this type present much the same appearance as those of the vesbal. There are the same rounded leucite phenocrysts, showing feeble double refraction and carrying few inclusions, but they are not nearly as thickly scattered as in the preceding type. On the other hand, phenocrysts of pale-gray augite are much more abundant, and one or two subhedral olivine phenocrysts are seen in the section.

The groundmass between these is like the preceding, especially in the plagioclase laths and their diverse arrangement, giving rise to a somewhat intersertal fabric. Leucite anhedra are common, this mineral often forming irregular interstitial areas. Small grains of augite are abundant, though less so than in the preceding type, as much of this mineral is here developed phenocrystically. There are also small anhedra of olivine and considerable residual base, which may be of glass, but is nephelite for the most part. The usual magnetite grains and apatite prisms may also be mentioned.

Chemical composition and mode.-No analysis has been made of a rock of this type, so that it is uncertain whether the classificatory position assigned to it is correct or not. As, however, all the other Vesuvian lavas analyzed by me, and many of those analyzed by others, fall in braccianose, there is little room for doubt that some, if not most, of the rocks with this mode and texture are really in this subrang.

The mode could not be satisfactorily estimated by microscopic methods, but the study of the thin sections indicates clearly that it must be quite similar to that of the vesbal type, though possibly with slightly greater relative amounts of alferric minerals.

Occurrence.-The most typical occurrence of this rock is the flow of I754 near Bosco Reale at Mount Vesuvius. Other flows which belong to this type, as determined by specimens examined by me, are those of I 750, I75 I, I 77 I, I834, and I858, while the descriptions of Fuchs lead one to refer here as well those of 1809,1832 , and $\mathrm{r} 839$. The type is also abundant at the encircling Monte Somma, both in the lava flows and the dikes. 
Name.-The type derives its name from Monte Somma, where it occurs abundantly. In the prevailing systems of classification it would be called a leucitetephrite, the small amount of olivine being regarded as negligible.

\section{7. 2. 2. Galeral Braccianose [Leucitite, Galera Type].}

Field characters.-This type is very dark, compact and heavy. It is only slightly porphyritic megascopically or aphyric, phenocrysts of leucite making up less than 5 per cent of the rock volume and sometimes being absent. They are usually well-formed trapezohedra, often fragmentary, white or very pale gray, and often with a slightly waxy luster, and vary in diameter from 5 to $10 \mathrm{~mm}$. Small phenocrysts of augite are either wholly wanting (the typical case) or are present in extremely small quantities. No other phenocrysts are found. The groundmass is a typical basaltic one, very dark gray or almost black, fine-grained, and aphanitic, but without a vitreous luster. Some of the specimens show a few vesicles, but the majority are quite free from them. The type would be called a leucitic melaphyre or a basalt in the field.

Microscopic characters. - The very few large leucites seen in the thin sections show the usual characters, good development of the crystalline form, often fragmentary, pronounced birefringence, and comparatively few inclusions. The still rarer large augite phenocrysts call for no remark, as they are of the type common in the region, and already often described.

The groundmass is percrystalline and microporphyritic, and shows a fabric which is highly characteristic of many of the more femic leucite rocks of the region. Leucite microphenocrysts are abundant, making up about one-third of the rock. They present rounded circular sections, and are usually anhedral, though occasional crystal planes are seen. Their size is fairly uniform, mostly between 0.20 and $0.30 \mathrm{~mm}$. in diameter, though smaller and slightly larger individuals occur. Double refraction is faint, but readily seen with the selenite plate. Inclusions are apt to be few, but some specimens show many small ones, of glass, augite, or magnetite, which usually form a circular ring near the periphery of the crystal, or else are arranged so as to show a skeletal development of the leucite. Rarely the original skeleton forms are well preserved.

Between these leucites is the microgroundmass, which consists in great part of a felted mass of very minute, pale, greenish-gray prisms of augite, with occasional larger individuals, which are to be regarded as microphenocrysts. While the general arrangement of these small prisms is diverse, adjacent to the leucites they are tangential, as if they had been present in the still molten magma prior to the complete crystallization of the salic mineral and had been shoved aside during its growth. With these augites are small grains of magnetite, as well as some laths of feldspar, which is mostly a labradorite.

Acting as a cement for these crystals is a clear, colorless substance, the amount of which is very difficult to estimate on account of the close juxtaposition and mostly 
felted arrangement of the numerous augite prismoids. In part this is seen between crossed nicols to be feldspar-both labradorite and to a less extent orthoclase-in micropoikilitic patches, and in part an isotropic glass of about the same refractive index as the leucite, though usually slightly lower.

In a general way this groundmass resembles in mode and fabric the vesbal type, though on a much smaller scale and with a much more pronouncedly tangential arrangement of the augite prismoids. The effect, especially when the leucites carry few or no inclusions, is that of a net or section of a sponge, the felted mass of augite prismoids representing the threads or walls and the clear, colorless, round leucites the holes. This microtexture is so characteristic of many of the rocks of the region, and so easily recognizable that it is well-deserving of a special name. For this the term clathrate* may be used, borrowed from the glossaries of botany and zoölogy. It is, of course, conceivable that a similar textural habit may be produced by the equant, spheroidal development of other salic minerals, as quartz, feldspar, nephelite, or the sodalites, along with the similar interstitial felt of augite or other alferric prismoids, though this is obviously not a very probable occurrence, and is as yet unknown as far as my knowledge extends, the texture being confined to leucite-augite rocks.

As this habit, characterized by the development of leucite in round microphenocrysts, surrounded by smaller and more or less tangential subhedral to anhedral augite prisms, is very common in the Roman Region and characteristic of many of the more femic rocks, it may well be given a special name. For this the term galeroid would seem appropriate.

Chemical composition.-An analysis of this type, published in incomplete form some years ago, is given below, with the addition of determinations of some of the minor constituents. The analysis of vesbal braccianose is also repeated for comparison.

Chemical Composition of Galeral Braccianose [Leucitite].

\begin{tabular}{|c|c|c|c|c|c|c|c|c|c|}
\hline & \multicolumn{2}{|c|}{ I. } & \multicolumn{2}{|c|}{ II. } & & \multicolumn{2}{|c|}{ I. } & \multicolumn{2}{|c|}{ II. } \\
\hline \multirow{9}{*}{$\begin{array}{l}\mathrm{SiO}_{2} . . \\
\mathrm{Al}_{2} \mathrm{O}_{3} \\
\mathrm{Fe}_{2} \mathrm{O}_{3} \\
\mathrm{FeO} . \\
\mathrm{MgO} \\
\mathrm{CaO} \\
\mathrm{Na}_{2} \mathrm{O} \\
\mathrm{K}_{2} \mathrm{O} \\
\mathrm{H}_{2} \mathrm{O}+ \\
\mathrm{H}_{2} \mathrm{O}-\end{array}$} & 47.89 & o. $79^{8}$ & 47.65 & 0.794 & $\mathrm{CO}_{2}$. & none & & none & \\
\hline & 17.87 & . I 75 & 18.13 & .178 & $\mathrm{TiO}_{2}$ & 0.77 & 0.010 & I. 13 & 0.014 \\
\hline & 4.93 & $.03 \mathrm{I}$ & 2.63 & .017 & $\mathrm{ZrO}_{2}$. & 0.02 & & 0.02 & \\
\hline & 3.64 & .050 & 6.48 & $.090^{\circ}$ & $\mathrm{P}_{2} \mathrm{O}_{5}$ & 0.36 & .003 & 0.50 & .004 \\
\hline & 3.68 & .092 & 4. 19 & .105 & $\mathrm{SO}_{3}$. & 0.06 & & trace & \\
\hline & 8.70 & .155 & 9.01 & . 161 & $\mathrm{MnO}$ & n.d. & & n.d. & \\
\hline & 2.60 & .042 & 2.78 & .045 & $\mathrm{BaO} \ldots$ & 0.28 & & 0.24 & \\
\hline & $\begin{array}{l}8.23 \\
0.65\end{array}$ & .087 & $\begin{array}{l}7.47 \\
0.13\end{array}$ & .080 & & 99.68 & & 100.47 & \\
\hline & $\ldots$ & & O.II & & Sp. gr. . & $2.78 \mathrm{r}$ & & & \\
\hline
\end{tabular}

I . Galeral braccianose [leucitite]. West of Crocicchie, south of Lake Bracciano, Sabatinian District. Washington, analyst. Jour. Geol., V, 1897, p. 49.

II. Vesbal braccianose [leucite-tephrite]. Lava of $\mathrm{x} 872$, below Observatory, Mount Vesuvius. Cf. p. 104 .

* From Latin clathratus, latticed. 
Norm of $I$.

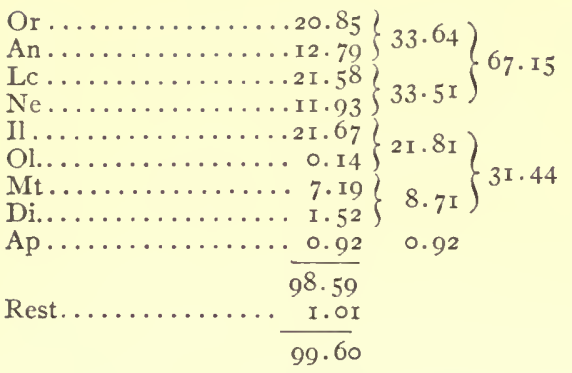

Ratios of $I$.

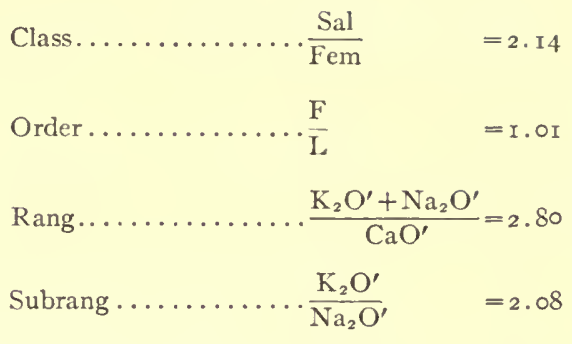

The analysis shows the generally central position of this type in the various classificatory divisions, in which it differs somewhat from the other, though the similarity between the two analyses is marked.

Mode.-Owing to the character of the groundmass, Rosiwal's method is not applicable to this type, though the relative amount by volume of the leucite microphenocrysts was determined rather satisfactorily. Recalculation of the norm was somewhat uncertain, because of ignorance of the relative amounts of alkali-feldspar and nephelite, but as the amount of the latter was small, the error involved in the arbitrary assumptions made as to it will not affect the result seriously. Assuming that it has the composition below and that about 5 per cent is present, the following mode was obtained, which may be regarded as closely approximating to the truth. The amount of leucite shown agrees reasonably well with the measured amount, especially when the leucite megaphenocrysts are taken into consideration, though it is somewhat higher. The nephelite given here exists for the most part as glass.

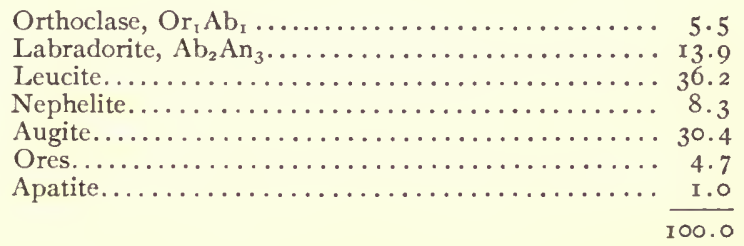

Occurrence.-This type is especially well represented in the Sabatinian District, practically all of the extensive flows of leucite-melaphyre (leucitite) south of Lake Bracciano belonging to it. Some prominent localities are Crocicchie, the quarry of L'Uomo Morto, Grotta Lobbra, La Toraccia, and other points along and close to the south shore, and the Osteria Nuova and elsewhere in the neighborhood of Santa Maria di Galera. The type also occurs in the Vulsinian District, as at Trebianello and Il Giglio to the east of Lake Bolsena, and probably also in the Latian and Auruncan districts, though none of my specimens can be definitely referred to this subrang.

Name.-The type name is derived from the locality of Santa Maria di Galera, one of the oldest-known occurrences. 
The type has been uniformly called leucitite by petrographers, and the name is justifiable in the prevalent systems, on acccount of the small amount and inconspicuousness of the feldspars, though the presence of these in the Galera rock, and its consequent relation to the leucite-tephrites, is noted by Rosenbusch.

GALERAL BRACCIANOSE. II. 7. 2.2.

Megascopic characters.-Very dark gray or black, compact, aphyric, or very slightly porphyritic. Leucite phenocrysts rare, $\mathrm{I}$ to $5 \mathrm{~mm}$., euhedral, equant, white, quite conspicuous. Augite phenocrysts very rare, I to $3 \mathrm{~mm}$., prismatic, black. Groundmass, very dark gray or black, aphanitic, not vitreous.

Microscopic characters.-Holocrystalline to percrystalline, microporphyritic. Megaphenocrysts, none to 5 per cent, leucite, augite. Microphenocrysts, about 50 per cent, leucite, augite. Microgroundmass, about $5^{\circ}$ per cent, augite, labradorite, nephelite (not always present), orthoclase, magnetite, apatite, glass (not always present). Groundmass has clathrate fabric.

Orthoclase, $\mathrm{Or}_{\mathrm{r}} \mathrm{Ab}_{\mathrm{r}}$. - Groundmass: 5 to o per cent, anhedral, interstitial, distinguishable with difficulty.

Labradorite, $\mathrm{Ab}_{2} \mathrm{An}_{3}$. - Groundmass: about ro per cent, anhedral, to a small part tabular, mostly anhedral, interstitial patches.

Leucite.-Megaphenocrysts: 2 to $\circ$ per cent, I to $5 \mathrm{~mm}$., euhedral, equant, sometimes fragmentary, inclusions few. Microphenocrysts: about 35 per cent, 0 . I to $0.4 \mathrm{~mm}$., anhedral equant, more or less circular sections, often skeleton forms, inclusions few to common, regularly arranged.

Nephelite.-Groundmass: about 6 per cent, anhedral, interstitial cement.

A ugite.-Megaphenocrysts: 2 to $\circ$ per cent, I to $3 \mathrm{~mm}$., subhedral, prismatic, often fragmentary, greenish-gray. Microphenocrysts: about ro per cent, 0.1 to $0.3 \mathrm{~mm}$., anhedral, prismatic, greenish-gray. Microgroundmass: about 20 per cent, 0.02 to $0.10 \mathrm{~mm}$., anhedral, prismatic to equant, pale greenish-gray, arrangement partly diverse, partly tangential, around the leucite microphenocrysts.

Magnetite.-Groundmass: about 5 per cent, 0.02 to $0.05 \mathrm{~mm}$., anhedral, equant.

A patite-Groundmass: about I per cent, 0.05 to o. ro mm., subhedral, prismatic.

Glass. -5 to o per cent, colorless to pale brown, usually absent.

Chemical composition and norm as on p. rog.

Type specimens from Crocicchie, south of Lake Bracciano, Sabatinian District.

\section{7. 2. 2. Hernical Braccianose [Leucitite, Hernici Type].}

Megascopic characters.-Rocks of this type are dense, very dark gray or almost black, and either very fine-grained or quite aphanitic, but without glassy luster. They are typically aphyric, phenocrysts being either wholly wanting, or in some cases with small and rare ones of augite and leucite, which never form more than I or 2 per cent of the total volume. Vesicular forms may occur, but most of the specimens are perfectly compact. In the field they would be called typical basalts.

Microscopic characters.-Under the microscope the rock is seen to be composed predominantly of leucite and augite, with a little feldspar and accessory magnetite and apatite. The texture, different from the clathrate one with numerous leucite microphenocrysts of the galeral type, is a xenomorphic granular one. Neither the leucite nor the augite are definitely phenocrystic, nor do either of them show much tendency to automorphic development, but of the two the augite is the more automorphic and has a greater tendenry to form phenocrysts. Textures 
transitional toward the clathrate one are not uncommon, so that it is, at times, difficult to say to which type some rocks belong.

The leucite, which constitutes about 40 per cent of the rock, is in subhedral to anhedral individuals, sometimes rounded and again rather irregular, interstitial between the augites. It is, however, usually equant, and often contains small inclusions of augite, magnetite, or glass, arranged zonally. Skeletal forms are rarely seen. In size the leucites vary much, though they are always microscopic, from 0.05 to $0.30 \mathrm{~mm}$., some of the more irregular patches being larger than this last.

The augite, of the usual pale-gray color, is almost as abundant as the leucite and is phenocrystic to some extent, in subhedral prismoids, often "corroded" and with irregular outlines, of from 0.5 to $x \mathrm{~mm}$. in length. But for the most part it forms subhedral to quite anhedral individuals, either stout prismoids or irregular grains and interstitial patches between the leucites. These augites are of dimensions commensurate with the leucites, from o. $\mathrm{x}$ to $0.5 \mathrm{~mm}$. long, and they are much stouter, larger, and more equantly developed than the small augites of the galeral type, in which the augite form is typically slender prismatic. Furthermore, they lack the felted arrangement and tangential position toward the leucites of this last type. With the above minerals are small grains of olivine and magnetite and very small apatite needles.

Lying between the larger leucites and augites, and inclosing the smaller crystals, is a colorless cement which the use of crossed nicols resolves into three distinct substances. Part of it is isotropic, of a slightly lower refractive index than the leucite, and may be considered a glass. Again, it is feebly doubly refracting without twinning lamellæ, probably nephelite, the presence of which is indicated by the calculation of the mode from the norm. Elsewhere this base consists of anhedral individuals of feldspar, the irregular patches of which extinguish simultaneously over considerable areas, and which inclose poikilitically the smaller leucites and augites. A small proportion of this feldspar is orthoclase, distinguished by its refractive index and by the simple Carlsbad twinning; but most of it is a multiplytwinned labradorite, of about the composition $\mathrm{Ab}_{1} \mathrm{An}_{3}$.

The origin of these poikilitic feldspars is somewhat problematical. In most of my specimens, especially those from Arcioni (one of which was chosen for analysis), I can not but regard it as primary, that is, one of the last products of crystallization, but antecedent to the nephelite and glass base. On the other hand, Sabatini* and Viola, $\uparrow$ who have studied it, the former in the Latian lavas and the latter in those of the Hernican District, regard it as secondary. This conclusion is based on the observations made by them that many individuals with the characteristic forms and inclusions of leucite show, between crossed nicols, the birefringence and multiple twinning of plagioclase, which varies in different cases from an oligoclase to anorthite. The twinning lamellæ pass out uninterruptedly from the apparent leucite crystal into a surrounding colorless patch of feldspar, of identical optical properties, extin-

* V. Sabatini, Boll. Soc. Geol. Ital., X (1896), p. 70, also Mem. descr. Carta Geol. Ilal., X, 1900, pp. 155, 263, 276.

† C. Viola, Boll. Com. Geol. Ital., I896, pp. 14, 23; Proc.Soc. Tosc., I896, p. I; Neu. Jahrb. 1899, I, pp. 127, 131. 
guishing as a whole or in separate twinning lamellæ simultaneously over considerable areas, which inclose poikilitically small augites and magnetites. These observations I have been able to confirm in sections kindly shown me by Signor Sabatini, but have been unable to discover any such cases in the specimens collected by myself, either from the Latian or Hernican districts. In all my specimens the leucite areas are dark between crossed nicols, or show the characteristic twinned structure, and interrupt the continuity of the lamellæ of the inclosing feldspar.

Chemical composition.-An analysis of this type was made on a specimen from Gli Arcioni, near Rocca di Papa,* in the Latian District, and is as yet unpublished.

Chemical Composition of Hernical Braccianose [Leucitite].

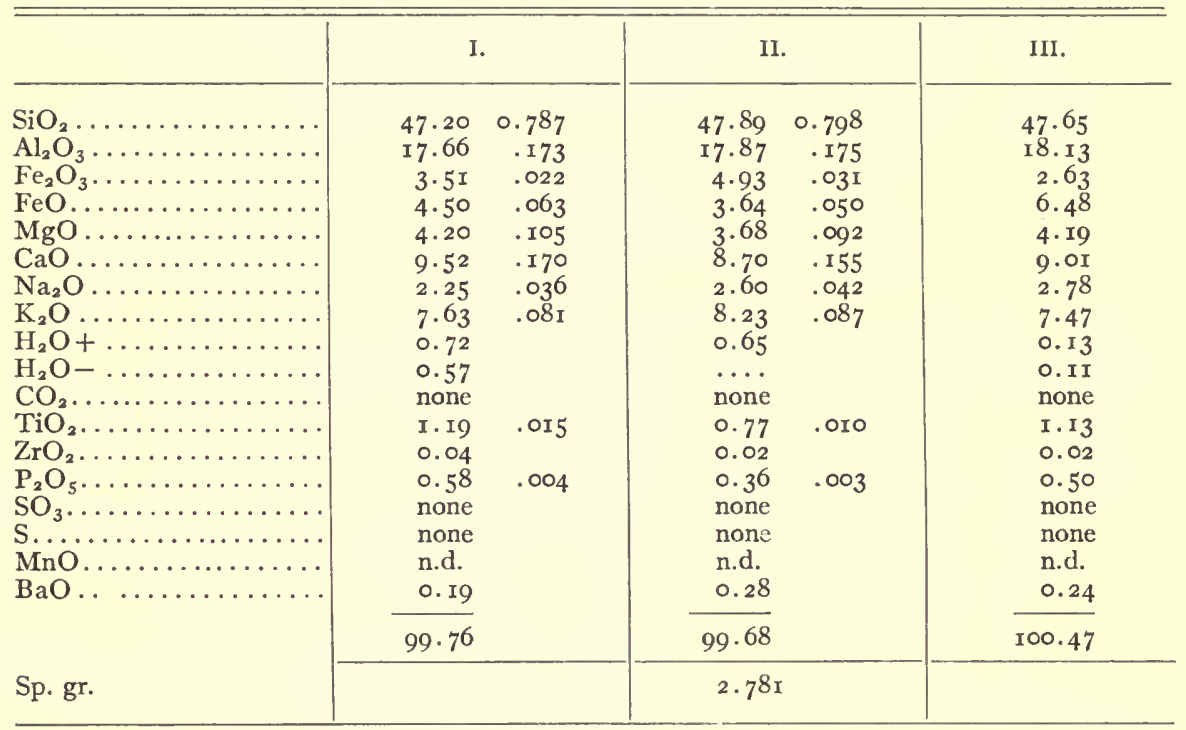

I. Hernical braccianose [leucitite]. Arcioni, Rocca di Papa, Latian District. Washington, analyst.

II. Galeral braccianose [leucitite]. Near Crocicchie, south of Lake Bracciano, Sabatinian District. Cf. p. Iog.

III. Vesbal braccianose [leucite-tephrite]. Lava of 1872 , Mount Vesuvius. Cf. p. I04.

Norm of $I$.

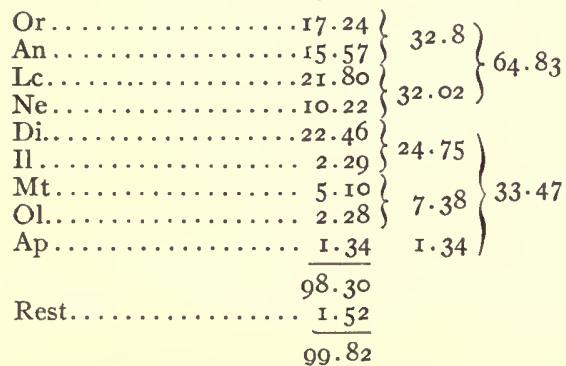

Ratios of $I$.
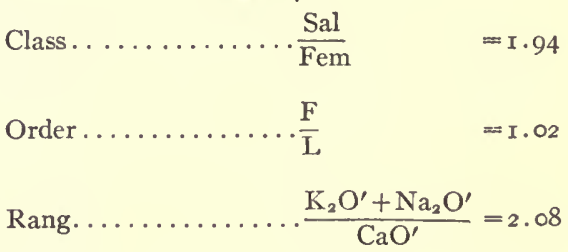

Subrang. . . . . . . $\quad=2.25$

* Cf. Sabatini, Mem. descr. Carla Geol. Ital., X, 1900, p. 260, fig. 58. 
The above analysis (I) calls for no comment, except to point out its great general resemblance to those of the other types of braccianose. It may also be noted that, while the total amounts of the two oxides of iron are about the same in all of the types, their relative amounts are distinctly different in the galeral and hernical from what they are in the types at Vesuvius, where they are very uniform, ferrous oxide being here largely in excess over ferric.

Mode.-As the rock was relatively large-grained, compared with the groundmasses of the other types of the same subrang, and as the size and equant shape of the crystals made it seem probable that the greater part of them would extend through the section, an attempt at measuring the mode under the microscope was made, with the result shown below. In this the leucite, feldspars, and nephelite and glass were necessarily measured together, as proper discrimination between them was difficult. The mode was also calculated in the usual"way from the norm.

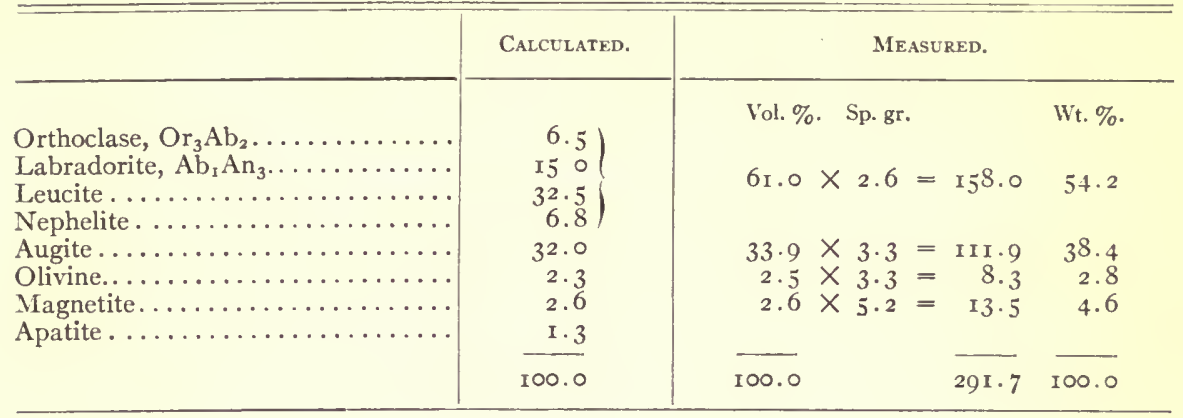

Evidently the influence of overlapping has been quite serious, being especially marked relatively in the case of the small magnetite grains. Of the two the calculated mode is the more authoritative.

Occurrence.-This type is abundant in the Latian District, as near Grotta Ferrata and Rocca di Papa, and in the Hernican District, two typical localities in this being the Torre di Pidocchia near Frosinone and blocks in tuff near the Casa Columbella near Pofi. It was also found in the Vulsinian District, especially near Montefiascone, as at the railroad tunnel and at Madonna d'Oro. It also probably occurs in the Sabatinian District, though my specimens of braccianose rocks from here are to be referred mostly to the galeral type, in which the leucite is phenocrystic rather than the augite.

Name.-The type name is derived from that of the Hernican District, where it seems to be common.

In the prevailing systems of classification these rocks would be called leucitites, like the preceding type, as the amount of feldspar is very small, though in some cases the name of leucite-tephrite might be applicable. 
HERNICAL BRACCIANOSE. II, 7, 2, 2,

Megascopic characters.-Very dark gray or black, compact, aphyric, or only slightly porphyritic. Augite phenocrysts rare, $\mathrm{x}$ to $3 \mathrm{~mm}$., prismatic, black. Leucite phenocrysts very rare, I to $4 \mathrm{~mm}$., equant, white or pale gray, inconspicuous. Groundmass very fine-grained or aphanitic.

Microscopic characters.-Holocrystalline, aphyric, few or no distinct phenocrysts, xenomorphic granular fabric, leucite, augite, labradorite, orthoclase, nephelite, olivine, magnetite, apatite.

Soda-orthoclase, $\mathrm{Or}_{3} \mathrm{Ab}_{2}$. - About 5 per cent, anhedral, as formless interstitial patches.

Labradorite, $\mathrm{Ab}_{\mathrm{r}} \mathrm{An}_{3}$. - About $\mathrm{r}_{5}$ per cent, anhedral, formless interstitial patches, multiply twinned.

Leucite. -30 to 35 per cent, 0.05 to $0.30 \mathrm{~mm}$., anhedral equant, less often irregular, interstitial between the augites, inclusions few, skeleton forms very rare.

Nephelite.-Groundmass: about 5 per cent, anhedral, formless, interstitial patches.

A ugite. -30 to 35 per cent, 0 . ro to $0.50 \mathrm{~mm}$., subhedral to anhedral, prismatic to equant, and irregular, greenish-gray, inclusions few.

Olivine.-About 2 per cent, 0.05 to 0 . Io mm., anhedral, equant.

Magnetite.-About 3 per cent, 0.02 to $0.05 \mathrm{~mm}$., anhedral, equant.

A patite.-About I per cent, 0.05 to $0.10 \mathrm{~mm}$., subhedral, prismatic.

Chemical composition and norm as on p. Ir 3 .

Type specimen from Arcioni, Rocca di Papa, Latian District.

\section{7. 2. 2. Atrial Braccianose [Leucite-Tephrite, Atrio Type].}

Megascopic characters.-This type, which must be regarded as much less precisely characterized than the preceding ones, occurs only as very small flows and as the borders and surfaces of larger ones, salbands of dikes, and crusts of bombs. The rocks are black or a very deep brown, evidently highly vitreous, and sprinkled with numerous small round spots of leucite, with only rare and small phenocrysts of feldspar, augite, and occasionally olivine, the last only as an accessory. Vesicular and scoriaceous forms are common.

Microscopic characters. - In thin section these rocks show many small (up to I or $2 \mathrm{~mm}$.), highly euhedral and trapezohedral sections of leucite, sometimes with and sometimes without inclusions of glass, etc. Leucite skeleton forms are very common. Leucite makes up about one-quarter of the rock volume, but the relative amount may vary rather widely. Tables and prisms of labradorite (from $A_{2} \mathrm{An}_{3}$ to $\mathrm{Ab}_{\mathbf{1}} \mathrm{An}_{3}$ ) are present in less amount, not over Io per cent, and also more or less euhedral phenocrysts of greenish-gray augite, which are apt to be equant rather than prismoidal. The amount of these is small, about that of the feldspars. There may be also a few olivines and magnetite grains, but always less than the two immediately preceding minerals. All these lie in a glass base, which is dark brown in color, either clear or dusty with indeterminable microlites, and which frequently shows flow textures.

Chemical composition.-An analysis was made of a specimen of this type, the material having been kindly furnished by Professor G. Mercalli, of Naples, who has published it elsewhere. 
Chemical Composition of Atrial Braccianose [Leucite-tephrite].

\begin{tabular}{|c|c|c|c|c|c|}
\hline \multirow[b]{2}{*}{ 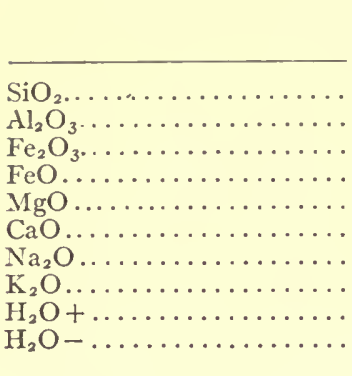 } & \multicolumn{2}{|c|}{ I. } & \multirow[b]{2}{*}{ 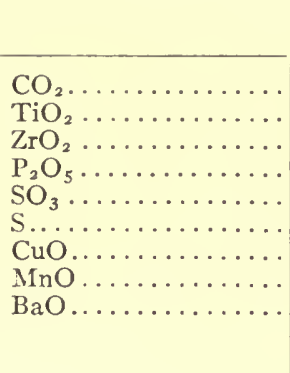 } & \multicolumn{2}{|c|}{ I. } \\
\hline & $\begin{array}{r}48.10 \\
17 \cdot 56 \\
2.48 \\
6.10 \\
4.27 \\
8.16 \\
2.65 \\
7 \cdot 93 \\
0.12 \\
0.04\end{array}$ & $\begin{array}{r}0.802 \\
.172 \\
.016 \\
.085 \\
.107 \\
.146 \\
.044 \\
.084\end{array}$ & & $\begin{array}{l}\text { none } \\
\text { I. } 4 \text { I } \\
\text { trace } \\
\text { I.0I } \\
\text { trace } \\
\text { none } \\
\text { none } \\
\text { n.d. } \\
0.08 \\
99.9 \mathrm{I}\end{array}$ & $\begin{array}{r}0.018 \\
.007\end{array}$ \\
\hline
\end{tabular}

I. Atrial braccianose [leucite-tephrite obsidian]. Lava of August 27, I9०3, Valle dell' Inferno, Mount Vesuvius. Washington, analyst. Cf. G. Mercalli, Boll. Soc. Sism. Ital., $\mathrm{X}, \mathrm{rg04}$, p. $2 \mathrm{r}$.

\section{Norm.}

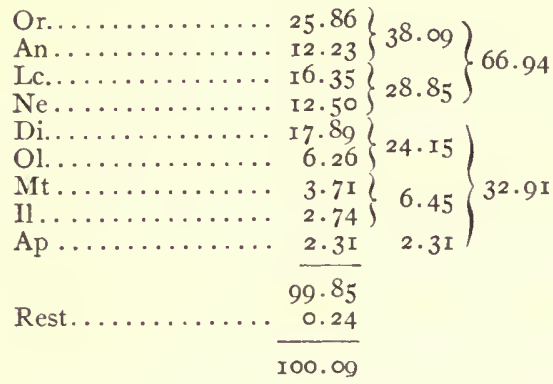

Ratios.

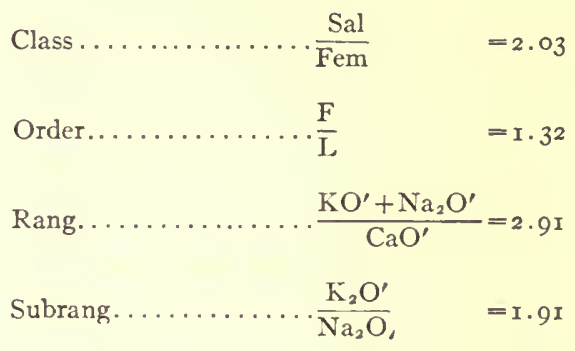

Of this analysis it need only be remarked that it resembles very closely those of the two preceding types.

Mode.-As the type is very highly vitreous, and therefore indeterminate, any exact statement of the mode is uncalled for. It will be of interest to state the relative amounts of the various minerals and glass, which are so easily estimated, the statement being based, of course, on the specimen analyzed. These figures may vary widely in other specimens.

\begin{tabular}{|c|c|c|c|c|c|}
\hline Leucite. . . . . . . . & $\begin{array}{r}\text { Vol. } \% \text {. } \\
26.4\end{array}$ & . Sp. gr. & . & 66.0 & $\begin{array}{c}\text { Wt. \%. } \\
24.6\end{array}$ \\
\hline Labradorite. . . . . . . . & . 5.9 & $\times 2.6$ & $=$ & $x_{5} \cdot 3$ & $5 \cdot 7$ \\
\hline Augite................ & $4 \cdot 5$ & $\times 3.3$ & $=$ & I 4.9 & 5.6 \\
\hline Magnetite............. & 0.6 & $\times 5.2$ & $=$ & 3.I & I.I \\
\hline \multirow[t]{2}{*}{ 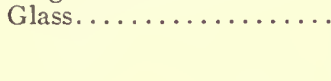 } & . 62.6 & $\times 2.7$ & $=$ & 169.0 & 63.0 \\
\hline & 100.0 & & & $268 \cdot 3$ & 100.0 \\
\hline
\end{tabular}

Occurrence.-As already stated, this type occurs only as flows of very small volume, as well as borders of larger flows and crusts of bombs at Mount Vesuvius, and also as narrow dikes and salbands of thick ones at Monte Somma. It has not been observed elsewhere in the Roman Region. 
Name.-The name of the type is derived from the Atrio del Cavallo, the semicircular valley between Vesuvius and Somma, into which so many of the small flows of the present cone run, and from the southern part of which the analyzed specimen was obtained.

In the prevailing systems the name of leucite-tephrite-obsidian is undoubtedly the correct appellation.

ATRIAL BRACCIANOSE. II. 7.2. 2.

Megascopic characters.-Very dark gray or black, sprinkled with small white spots, compact to vesicular, highly porphyritic. Leucite phenocrysts abundant, I to $3 \mathrm{~mm}$., round, white. Augite phenocrysts, very few, I to $2 \mathrm{~mm}$., prismatic, black, inconspicuous. Feldspar and olivine phenocrysts very rare or none, small. Groundmass: black, vitreous.

Microscopic characters.-Hyalocrystalline to dohyaline, porphyritic, dopatic to sempatic. Phenocrysts 20 to 40 per cent, leucite, augite, labradorite, magnetite, rarely olivine. Groundmass: 80 to 60 per cent, wholly glass, sometimes dusty with microlites.

Labradorite, $\mathrm{Ab}_{2} \mathrm{An}_{3}$ to $\mathrm{Ab}_{1} \mathrm{An}_{3}$.-Phenocrysts: 5 to xo per cent, 0 . I to $0.5 \mathrm{~mm}$., euhedral, thin prismatic or tabular, much twinned, few inclusions.

Leucite.-Phenocrysts: 20 to 30 per cent, 0.2 to $2.0 \mathrm{~mm}$., euhedral to subhedral, often clustered, sometimes skeleton forms, inclusions few.

Augite.-Phenocrysts: 5 to ro per cent, 0.2 to $\mathrm{x} .0 \mathrm{~mm}$., euhedral to subhedral, equant to prismatic, greenish-gray, few inclusions.

Magnetite.-Phenocrysts: about x per cent, 0.02 to $0.05 \mathrm{~mm}$., anhedral or skeletal.

Glass.-Yellowish-brown, often clear, sometimes mottled, sometimes dusty with indeterminable microlites.

Chemical composition and norm as on p. i 16 .

Type specimen from flow of 1903 , Valle del Inferno, Mount Vesuvius, Campanian Dis trict.

\section{8=7. 2. 2. Scalal Vesuvose=Braccianose [Leucite=Tephrite, Scala Type].}

Megascopic characters. - This type is porphyritic, but not as much so as in those just described. The phenocrysts are mostly of augite, with rare ones of olivine, but few or none of leucite, and do not make up more than about ro per cent of the rock volume. The augites are from 2 to $5 \mathrm{~mm}$. long, and prismatic rather than equant, the color a dark green. The rare olivines are about the same size, equant, and pale greenish-yellow. The groundmass in this type is a rather light gray, not nearly as dark as the preceding rocks, and is phanerocrystalline and fine-grained, the dark and light mineral particles being easily distinguishable with a lens. In the field rocks of this type would be called augite-leucophyres.

Microscopic characters.-The augite phenocrysts show subhedral and often fragmentary forms, and are of the usual very pale-gray color and quite free from inclusions. The very rare olivines present no features of special interest, but are not well developed crystallographically. An occasional leucite phenocryst is seen here and there, but these are as rare as are phenocrysts of augite in the vesbal type.

The groundmass is holocrystalline typically, though a trifling amount of glass may rarely be present. It is microporphyritic, small phenocrysts of leucite and augite lying in a microgroundmass which resembles the preceding in its intersertal fabric. The leucite microphenocrysts are very abundant, as is expected, since it does not occur as megaphenocrysts. They are anhedral and mostly spheroidal, 
though some irregular forms are noticed. They do not show very marked birefringence, and inclusions are few and irregularly arranged. The microphenocrysts of augite are anhedral to subhedral, generally prismatic, and of the same color as the larger ones.

The microgroundmass between these is composed of small tables of labradorite, with twinning and extinction angles which correspond to the composition $\mathrm{Ab}_{2} \mathrm{An}_{3}$, small irregular grains of augite and fewer of olivine, and the usual magnetite grains and apatite needles, neither of which are numerous. The arrangement of the feldspar tables is diverse, inclosing the other constituents. Between these well-defined minerals is a colorless residual cement, which in most specimens is somewhat birefringent and to be regarded as nephelite, which treatment of the rock powder with weak acid proves to be present, and there is occasionally an isotropic glass of similar composition.

Chemical composition.-An analysis of this type was made from material obtained at the quarries in the great flow of $\mathrm{x}_{3} \mathrm{r}$, at La Scala, near Torre del Greco, Mount Vesuvius. It has been already published, but in incomplete form and without any petrographic details. For comparison are also given two of the older analyses of the same rock.

Chemical Composition of Scalal Vesuvose-braccianose [Leucite-tephrite].

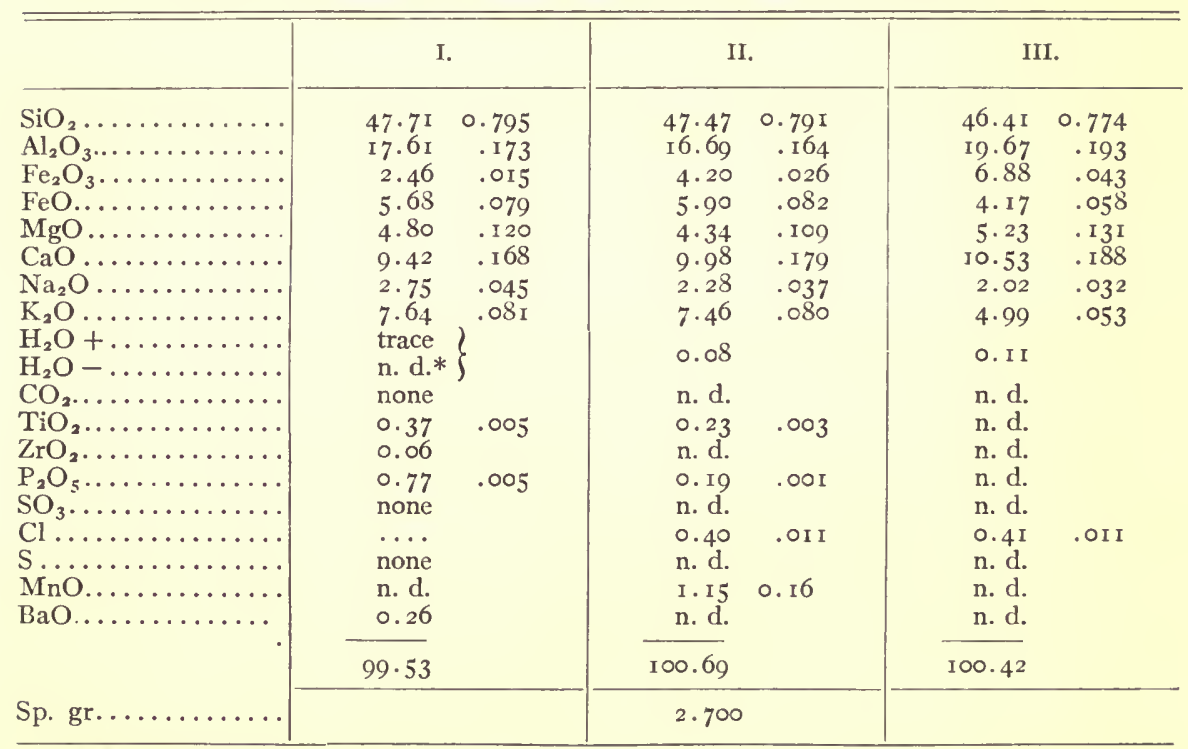

* Material dried at 1 ro․

I. Scalal vesuvose-braccianose [leucite-tephrite]. La Scala, Torre del Greco, Mount Vesuvius. Washington, analyst. Cf. Washington, Prof. Paper U. S. G. S. No. 14, 1903, p. 307 .

II. Scalal vesuvose-braccianose [leucite-tephrite]. Same locality. Haughton, analyst. Trans. R. Irish Acad., XXVI, I876, p. 77.

III. Scalal braccianose [leucite-tephrite]. Same locality. Fuchs, analyst. Neu. Jahrb., I866, p. 678 . 
Norm of $I$.

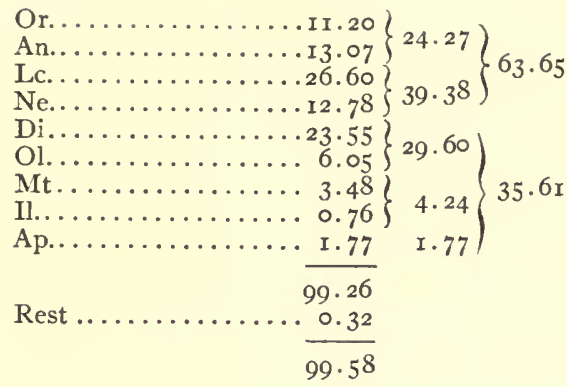

Ratios of $I$.

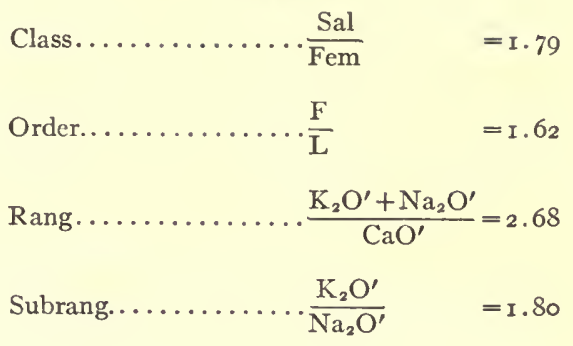

Comparison of this analysis with that of the vesbal type shows that the two are remarkably similar, the figures for silica and the alkalis especially being nearly duplicates. The ratios, however, show that this type is closer to the border of order 8 than the other, so close that it should be regarded as transitional between braccianose where it actually falls, and vesuvose, the homologous subrang in order 8 of dosalane. In fact this type was formerly assigned to the subrang of vesuvose* on the basis of the incomplete analysis, and the change in position is due to the determination of $\mathrm{P}_{2} \mathrm{O}_{5}$, which, by combining with $\mathrm{CaO}$ to form apatite, sets free sufficient $\mathrm{SiO}_{2}$ to change the relative amounts of orthoclase and leucite so that the ratio of feldspar to lenads is lenfelic rather than feldolenic.

Of the two older analyses, that of Haughton (II) most closely resembles the latest one, and must be regarded as the more correct. The only differences of note are the lower alumina and the very high figure for $\mathrm{MnO}$. This last is undoubtedly erroneous, as the amount of this constituent should not exceed 0.20 per cent, and it most probably arises from the common analytical mishap of incomplete precipitation of alumina, the unprecipitated portion of which is subsequently thrown down with the manganese and weighed as such. If this is assumed to be true and the apparent amount of $\mathrm{MnO}$ is added to that of $\mathrm{Al}_{2} \mathrm{O}_{3}$, the figure for the latter becomes $\mathrm{I}_{7} .82$, in close agreement with $\mathrm{I}$.

Of analysis III little need be said, except that it is undoubtedly incorrect in the figures for alkalis, especially potash. The amount shown allows of the formation of only 23.I per cent of leucite, which is much below the proportion which the microscope shows is present, and would lead to the presence of about 40 per cent of labradorite, $\mathrm{Ab}_{\mathrm{r}} \mathrm{An}_{2}$, a figure, on the other hand, much in excess of the actual amount.

Mode.-The estimation of the mode of this type is strictly analogous to that of the vesbal. While the augite megaphenocrysts could be estimated readily, and the microphenocrysts of leucite fairly well, the other constituents did not lend themselves to this method of procedure. On the other hand, the calculation of the mode from the norm presents no difficulty, and it is noteworthy that here, as in the vesbal type, the silica left available for soda after formation of augite, olivine, leucite, and

* See reference under the analysis. 
anorthite is just sufficient to yield the right amount of albite for the observed composition of the labradorite, using the regular equations.

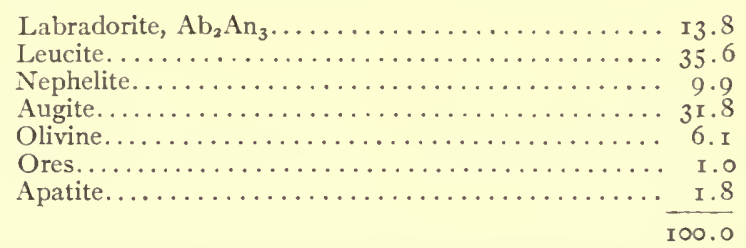

This result is very similar to the mode of the resbal type, and is in harmony with what we have noted of the rock characters. The amount of labradorite is lower and that of leucite higher in accord with its transitional magmatic position, and the slightly greater quantities of augite and olivine and less of ores agree with the microscopic observations. The presence of considerable nephelite was confirmed by treatment with very dilute acid, as in the previous case.

Occurrence.-Rocks of this type are only met with in the Campanian District, especially at Mount Vesuvius. Here they are most typically represented by the great flows of $163 \mathrm{r}$, which reached the sea at various points between Portici and Torre Annunziata. These are quarried extensively for use in Naples, especially at Granatello near Portici and La Scala near Torre del Greco. Specimens from the following flows, which have been examined by me, also belong to this type: $155 \mathrm{I}$, I 555, r806, I8ro, r822, I855. The descriptions of Fuchs and others do not allow of discrimination between this type and another with more abundant and larger augite megaphenocrysts.

Name.-The type derives its name from the locality, La Scala, of the quarry whence the material analyzed was derived. In prevailing classifications it would be known as a leucite-tephrite, as in the preceding types.

SCALAL VESUVOSE-BRACCIANOSE. II, 8-7, 2. 2.

Megascopic characters.-Light gray, compact, somewhat porphyritic. Augite phenocrysts not abundant, 2 to $5 \mathrm{~mm}$. long, prismatic, dark-green or black. Leucite phenocrysts very rare or none, I to $3 \mathrm{~mm}$., round, pale-gray or white. Olivine phenocrysts very few or none, 0.5 to $2 \mathrm{~mm}$., equant, pale greenish-yellow. Groundmass, light gray, very fine-grained, phanerocrystalline.

Microscopic characters.-Holocrystalline, mediophyric, perpatic. Phenocrysts: about Io per cent, augite, sometimes also leucite and olivine. Groundmass, about 90 per cent, microporphyritic. Microphenocrysts: about 50 per cent, leucite, augite. Microgroundmass: about 40 per cent, labradorite, augite, nephelite, magnetite, olivine, apatite.

Labradorite, $\mathrm{Ab}_{2} \mathrm{An}_{3}$.-Groundmass: about $\mathrm{I}_{4}$ per cent, 0.05 to $0.20 \mathrm{~mm}$., subhedral, thin tabular or prismatic, twinned, arrangement diverse.

Leucite.-Phenocrysts: none to 2 per cent 0.5 to $2.0 \mathrm{~mm}$., anhedral, equant to irregular. Microphenocrysts: about 35 per cent, o. I to $0.3 \mathrm{~mm}$., anhedral, equant to irregular, inclusions few.

Nephelite.-Groundmass: about 5 to ro per cent, anhedral, as interstitial cement.

Augite.-Megaphenocrysts: about ro per cent, 2 to $5 \mathrm{~mm}$., subhedral, prismatic, sometimes fragmentary, greenish-gray, few inclusions. Microphenocrysts: about ro per cent, o. I to $0.4 \mathrm{~mm}$., subhedral to anhedral, prismatic to equant, pale greenish-gray. Microgroundmass: about 10 per cent, 0.02 to $0.10 \mathrm{~mm}$., anhedral, equant. 
Olivine.-Phenocrysts: none to 2 per cent, 0.5 to $2.0 \mathrm{~mm}$., subhedral to anhedral, equant to fusiform, colorless. Groundmass: about 4 per cent, 0.2 to $0.02 \mathrm{~mm}$., anhedral, equant.

Magnetite.-Groundmass: about 2 per cent, 0.02 to $0.05 \mathrm{~mm}$., anhedral, equant.

A patite.-Groundmass: about 2 per cent, 0.05 to $1.0 \mathrm{~mm}$., subhedral, prismatic.

Chemical composition and norm as on p. Irg.

Type specimen from flow of $\mathrm{r}_{3} \mathrm{r}$, La Scala, near Torre del Greco, Mount Vesuvius, Campanian District.

\section{8. 2. 2. Romal Vesuvose [Leucitite, Rome Type].}

This type is as yet unestablished by an analysis, so that a brief description of it must suffice. It is based on several specimens which, on careful comparison with those of similar types of undoubted braccianose and albanose rocks, were judged to be intermediate between them, differing from the former in the total absence of feldspar between the leucite and small augite crystals, nephelite or glass in small amount replacing it, and from the latter by the considerably greater amount of leucite as compared with augite, indicating a position in dosalane rather than in salfemane. These measurements could not be carried out very exactly, for reasons given above, but the differences are clearly seen on comparison of the sections. It may also be added that the occurrence of such a type is to be expected in the region.

Megascopic characters. - The rocks are very dark gray or almost black, dense and compact, showing very few phenocrysts of leucite and augite. The groundmass is aphanitic, or extremely fine-grained.

Microscopic characters. - These correspond in every way with those described later under romal albanose, except that leucite is slightly more abundant. The fabric is in most cases a clathrate one, composed of numerous small, round anhedra of leucite, with some pale greenish-gray augite microphenocrysts, and an interstitial microgroundmass of small felted augite prisms, often tangential toward the leucites, with many minute magnetite grains. No feldspar is present, but between the augite prismoids is a colorless cement which is either nephelite or glass. Olivine does not often occur in this type, but a minimal amount may be present in some cases.

Chemical composition and mode.-As no chemical analysis of this type was available, the attempt was made to calculate the chemical composition from the measured mode. For this a specimen was chosen from a quarry opposite the railroad station of Oriolo, below Monte Raschio, in the Sabatinian District, as the amount of leucite seemed to be decidedly greater than in similar albanose rocks, and the grain was sufficiently large to allow fairly accurate measurements and with probably not very serious error from overlapping of the dark minerals. The results of this are seen below, in which the "augite" includes the small amount of nephelite base, the exact quantity of which is impossible to measure.

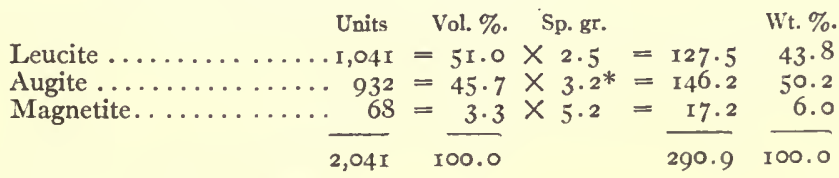

*3.3 corrected for 12 per cent of nephelite. 
The rough figures given above must, however, be corrected for the small amount of nephelite, and some correction must also be made for the overlap, which we have seen to be a common source of error in all these rocks. The amount of nephelite was assumed to be 6 per cent, which is probably slightly below the true figure, if we can judge by the analogy of the calculated modes of galeral and hernical braccianose. To estimate the amount of error due to overlap, the calculated and measured modes of hernical braccianose (p. II4) were taken as the basis, as the two are similar in grain. On the assumption that the errors here are about the same, the observed amount of leucite was increased by one-tenth, that of magnetite reduced to one-half, and the balance referred to augite, after subtracting the 6 per cent of nephelite from this. The corrected mode would then be:

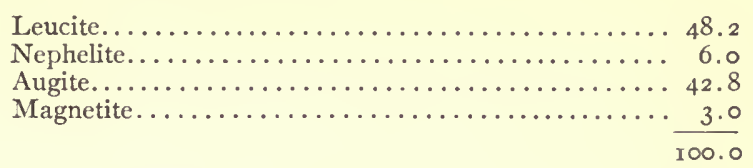

To calculate the chemical composition from this the leucite was assumed to have the composition of that of Mount Vesuvius as analyzed by Steiger,* the nephelite that of Vesuvius as analyzed by Rauff, $\uparrow$ and the augite that of Ticchiena as analyzed by myself. The magnetite was assumed to be free from titanium. Using these data, the chemical composition of the rock and the norm are calculated to be:

Chemical Composition.

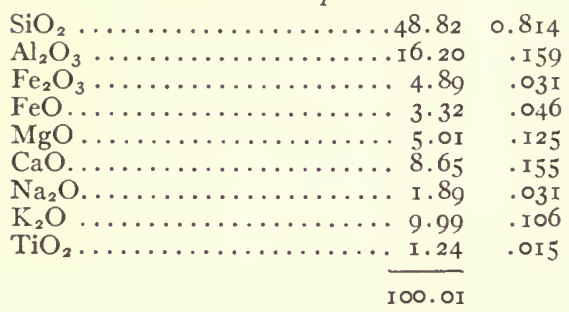

Norm.

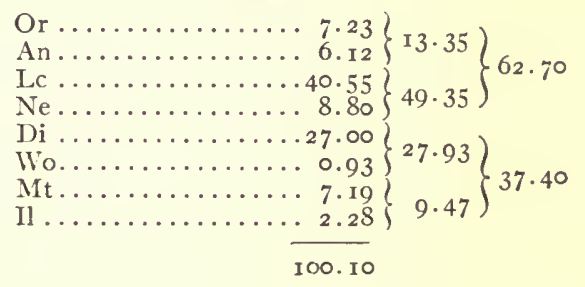

This analysis resembles very closely those of the braccianose types and, as will be seen, those of albanose rocks, the chief difference being the higher potash. Examination of the norm shows that while it is well within the limits of order 8, rang 2 , and subrang 2 , it is almost exactly on the line between dosalane (in which it falls) and salfemane, and is consequently an albanose-vesuvose.

Occurrence.--Rocks which may be provisionally referred to this type, though texturally some of them have a fabric which is saccal rather than romal, are found in the Vulsinian District at the Sassi Lanciati and in the Fossa Melona on the east shore of Lake Bolsena, in the Sabatinian at Oriolo and on the north side of Lagosello, and in the Auruncan below Preta.

\footnotetext{
* Bull. U. S. Geol. Surv. No. 220, 1903, p. 30.

† Zcits. Kryst., II, 1878, I. 454; Dana, Mineralogy, No. 6, p. 425.

$\ddagger$ Cf. p. 134 .
} 
Name.-The subrang name is derived from that of Mount Vesuvius, on the basis of the position formerly* assigned the types of vesbal and scalal braccianose. But, as we have seen above, $\uparrow$ these rocks do not properly fall in vesuvose (II. 8. 2. 2), but in braccianose (II. 7.2.2). The error is an unfortunate one and the subrang II. 7. 2. 2 could appropriately be called vesuvose, as this subrang is very abundant and characteristic at Vesuvius. But on the grounds of priority and previous publication, and on account of the liability to misunderstanding if a change is made, it is deemed best to preserve the names with their original significations as to rang and subrang. The type name will be discussed later.

In the prevailing systems of classification this type would be included among the leucitites, consisting, as the rocks do almost exclusively, of leucite and augite.

\section{8-7. 2. 2. Galeral Albanose=Jugose [Leucitite, Galera Type].}

Megascopic characters. - In the hand specimen this type can not be distinguished from galeral braccianose, vesuvose, or albanose. The rock is very dark gray or black, with rare phenocrysts of leucite or augite in the aphanitic or very finegrained groundmass, and is typically a basalt, or a melaphyre if the few phenocrysts are considered to be of importance. Vesicular forms seem to be uncommon, and all my specimens are very compact.

Microscopic characters. - In thin section likewise it is a matter of great difficulty, if not an impossibility in some cases, to discriminate between this type and those mentioned above. But in general the greater amount of augite serves to distinguish them from the braccianose and the presence of small amounts of feldspar from the albanose.

In the type specimens the leucite phenocrysts are rarely seen in the section and call for no description. Those of augite are more numerous, from 0.5 to $1.0 \mathrm{~mm}$. long, stoutly prismatic and subhedral, and of the usual very pale-gray color, almost wholly without inclusions. The microgroundmass shows a clathrate fabric, with abundant small round leucite anhedra, weakly birefringent, between which lie many small prismoids and grains of common augite. In the type specimen the tangential arrangement of the prisms is not so well marked as in the galeral braccianose from Crocicchie, and the small augites are rather more often in the form of equant grains, showing a transition toward the hernical type, but the characteristic round leucites indicate that the fabric may still be called clathrate. There are many small and irregular grains of magnetite and some olivine grains and apatite needles. Between these small crystals is a colorless base, in part isotropic, but the greater part of this is doubly refracting, with an index of refraction and birefringence decidedly greater than leucite, and apparently greater also than nephelite. Though this shows no twinning lamellæ it may be regarded as feldspar, mostly plagioclase, which the calculated norm shows to be present, and as treatment of the rock powder with dilute acid furnished only very small amounts of gelatinous silica. In some of

* Washington, Prof. Paper U. S. Geol. Surv. No. 14, 1903, p. 307.

$\dagger$ Cf. pp. 104 and 119. 
the sections there is a very small amount of yellowish melilite in interstitial patches, marking a transition toward the boval type to be described later, but this mineral here is quite negligible. Glass does not seem to be present, at least to a notable extent.

Chemical composition.-An analysis of this type was made from the quarry at Monte Jugo, the specimen being selected from this small flow so as to furnish a basis of comparison with Ricciardi's analysis, without chance of great differences in the results due to variations in the mass of rock. For this purpose his analysis of the same rock is also given in II.

Chemical Composition of Galeral Albanose-jugose [Leucitite].

\begin{tabular}{|c|c|c|c|c|c|c|c|c|c|}
\hline \multirow[b]{2}{*}{ 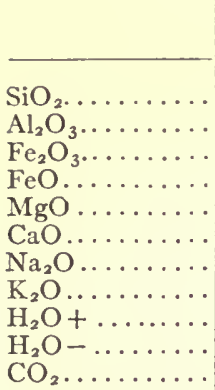 } & \multicolumn{2}{|l|}{ I. } & \multicolumn{2}{|c|}{ II. } & & \multicolumn{2}{|c|}{ I. } & \multicolumn{2}{|c|}{ II. } \\
\hline & 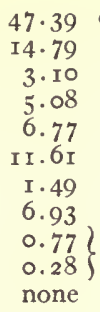 & $\begin{array}{r}0.790 \\
.145 \\
.019 \\
.071 \\
.169 \\
.207 \\
.024 \\
.073 \\
\end{array}$ & $\begin{array}{r}48.30 \\
\text { I5.07 } \\
\text { I. } 53 \\
9.18 \\
7.48 \\
\text { I } 3.95 \\
0.94 \\
\text { I. } 73 \\
\text { I. } 78 \\
\ldots \ldots\end{array}$ & $\begin{array}{r}0.805 \\
.148 \\
.009 \\
.128 \\
.187 \\
.249 \\
.015 \\
.018\end{array}$ & 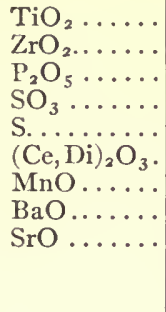 & $\begin{array}{l}\text { I. } 4 \text { I } \\
0.04 \\
0.45 \\
\text { none } \\
\text { none } \\
0.05 \\
\text { n.d. } \\
0.15 \\
0.04 \\
\end{array}$ & $\begin{array}{r}.018 \\
0.003\end{array}$ & $\begin{array}{l}\ldots \\
\ldots \\
0.47 \\
\ldots \\
\ldots \\
\cdots \\
0.29 \\
\ldots \\
\ldots\end{array}$ & 0.003 \\
\hline
\end{tabular}

I. Galeral albanose-jugose [leucitite]. Monte Jugo, south of Montefiascone, Vulsinian District. Washington, analyst.

II. Same rock. Same locality. Ricciardi, analyst. Cf. Klein, Neu. Jahrb., B. B. VI, r889, p. 20.

Norm of $I$.

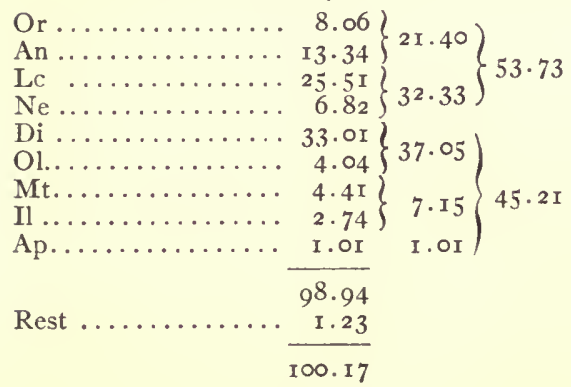

Ratios of $I$.

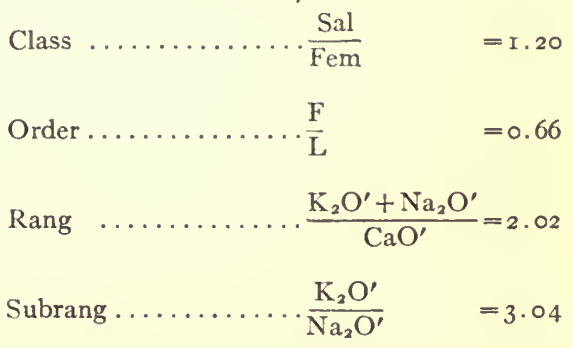

This analysis differs from all those previously given in the lower alumina and higher lime, this change marking the position of the rock in the salfemane class. As regards the magmatic position the type is well toward the center of the various divisions, except in that of rang, where it stands almost exactly on the border between rangs 7 and 8 , so that the subrang is transitional between jugose (III. 7.2.2), where it belongs strictly, and albanose (III. 8. 2. 2).

Analysis II resembles I rather closely in silica, alumina, magnesia, soda, and phosphoric oxide, but differs to a very marked extent in the oxides of iron, espe- 
cially ferrous, lime, and potash. That the last is very much too low is clear from the fact that $\mathrm{r} .73$ per cent of potash would furnish but 7.85 per cent of leucite, a figure which is only about one-quarter of the amount of this mineral actually present. The norm of analysis II would place the rock in auvergnose (with gabbros, diabases, and feldspar-basalts), no leucitic types of which have ever been described or probably could exist, and, furthermore, all rocks with high (about 50 per cent) feldspar, especially plagioclase, which is almost wanting in the Monte Jugo rock, as we have seen. This analysis of Ricciardi's must then be rejected, as well as many others of similar rocks published in the above-cited paper by Klein, study of the norms and the possible mineral compositions showing them to be quite unreliable.

Mode.-The mode was calculated from the norm, the figures being checked so far as possible by study of sections under the microscope. In this calculation all the potash was assumed to go into leucite and the augite to have the usual composition.

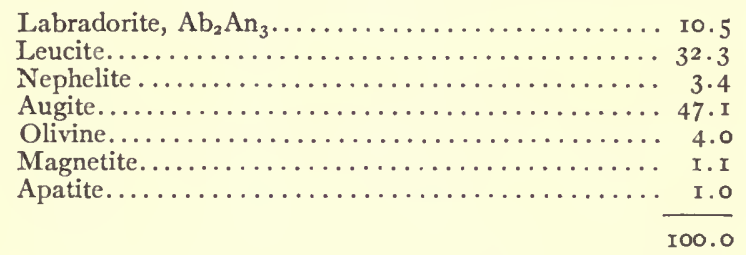

Occurrence.-This type is confined, apparently, to the Vulsinian District, the type specimen coming from the small parasitic cone of Monte Jugo, in the southeastern part. Other specimens which may be referred here are from the quarry of Le Grazie near Montefiascone, from La Canonica near Orvieto, and from blocks southwest of Valentino.

Name.-The name of the subrang III. 7.2.2 is, of course, derived from that of the small cone from which comes the type specimen. The type rock from this locality is called by Klein* "a leucite-tephrite, passing into leucitite." In view of the very subordinate amount of feldspar it would seem that the name leucitite would be appropriate in prevailing classifications.

GALERAL ALBANOSE-JUGOSE. II. 8-7. 2. 2.

Megascopic characters.-Very dark gray or black, compact, aphyric, or with very rare phenocrysts of leucite and augite. Groundmass aphanitic.

Microscopic characters.-Holocrystalline, microporphyritic, somewhat clathrate fabric. Microphenocrysts: about 45 per cent, leucite, augite. Microgroundmass: about 55 per cent, augite, labradorite, olivine, nephelite, magnetite, apatite.

Labradorite, $\mathrm{Ab}_{2} \mathrm{An}_{3}$.-Groundmass: about ro per cent, anhedral, as formless interstitial areas.

Leucite.-Microphenocrysts: about 30 per cent, 0 . 1o to $0.20 \mathrm{~mm}$., anhedral, equant, circular sections, inclusions few.

Nephelite.-Groundmass: less than 5 per cent, anhedral, formless, interstitial areas, difficult to detect.

* K!ein, Neu. Jahrb., B. B. VI, I889, p. 20. 
Augite.-Microphenocrysts: about I5 per cent, O. Io to $0.50 \mathrm{~mm}$., anhedral to subhedral, prismatic and fragmentary, pale greenish-gray, often zonal, inclusions few. Groundmass: about 30 per cent, 0.02 to $0.10 \mathrm{~mm}$., anhedral, prismatic to equant, very pale greenish-gray, arrangement somewhat tangential around the leucites.

Olivine.-Groundmass: about 4 per cent, 0.05 to o. 10, anhedral, equant, colorless.

Magnetite.-About 2 per cent, o.or to $0.05 \mathrm{~mm}$., anhedral, equant.

A patite.-About I per cent, 0.02 to $0.05 \mathrm{~mm}$., subhedral, prismatic.

Chemical composition and norm as on p. I 24 .

Type specimen from Monte Jugo, Vulsinian District.

\section{7. 3. 2. Fiordinal Fiasconose [Leucite-Basanite, Fiordine Type].}

Megascopic characters. - This type is very dark gray and porphyritic. Abundant phenocrysts of dark-green or black augite, from 2 to to and even $20 \mathrm{~mm}$. long, with fewer but still numerous phenocrysts of olive-green olivine, of about the same sizes, constitute some 30 per cent of the rock volume. The groundmass in which they lie is dark gray, compact, and quite aphanitic. The rock is dense and heavy, evidently highly femic, and in the field would go under the name of olivineaugite melaphyre.

Microscopic characters. - The very abundant augite phenocrysts are for the most part euhedral to subhedral, often "corroded" at the borders into small pits and pockets, and not uncommonly fragmentary. They are of the usual very pale-gray color, here without any tinge of green, and are remarkably free from inclusions, small grains of magnetite being the only ones observed. The large olivines are similarly euhedral to subhedral, often fragmentary, showing the common simple planes, quite colorless, as free from inclusions as the augites (here also magnetite being the only included mineral), and are quite fresh, except for a thin external dark brown zone.

The groundmass in which these lie contains many small, equant anhedra of augite and euhedral crystals of olivine which run serially up to the phenocrysts in size. With them are considerable numbers of very small, round, water-clear leucites, in part subhedral with crystal planes and in part completely anhedral, the double refraction being weak but discernible with a selenite plate. There are also a few small, irregular areas of brownish biotite and some magnetite grains, but no feldspar laths or apatite.

The colorless base between these crystals shows considerable diversity in different parts of the section. In places it shows the birefringence and twinning lamellæ of plagioclase, the extinction angles of which correspond to an almost pure anorthite. These feldspars form irregular areas inclosing poikilitically the smaller crystals, and with the small leucites standing out well against them on account of the considerably lower refractive index. Elsewhere the patches are more feebly birefringent and without twinning lamellæ, and a re regarded as nephelite, while again the base is isotropic, and is either nephelite in basal section or less commonly glass.

Chemical composition.-An analysis of the rock from near Fiordine was made, a large amount of material being taken to obtain a representative sample. For com- 
parison is also given the only other known analysis of a rock of the same subrang, a "ouachitite" from a dike near Hot Springs in Arkansas. According to Kemp's description* this is highly biotitic and is to be regarded as a distinct type, to which the name of ouachital fiasconose may be given. An analysis of a rock from Montana belonging to a closely related magma, described by Pirsson, to which the type name of arrowal cascadose may be given, will be found in III.

Chemical Composition of Fiordinal Fiasconose [Leucite-basanite].

\begin{tabular}{|c|c|c|c|c|}
\hline & \multicolumn{2}{|c|}{ I. } & $\frac{\text { II. }}{36.40}$ & $\frac{\text { III. }}{46.04}$ \\
\hline 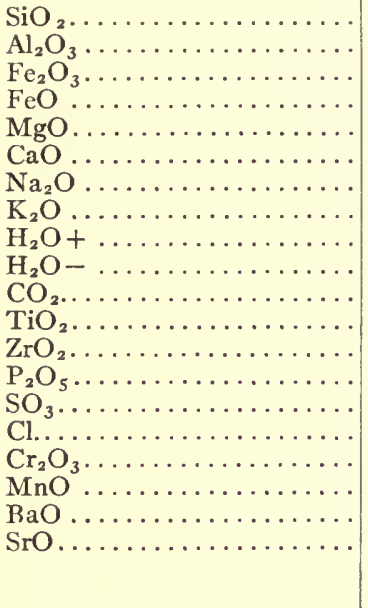 & $\begin{array}{r}44.89 \\
\mathrm{r} 2.73 \\
3.31 \\
4.35 \\
\mathrm{I} 3.71 \\
\mathrm{r} 2.85 \\
\mathrm{r} .02 \\
3.66 \\
\mathrm{I} .59 \\
0.27 \\
\text { non } \\
0.95 \\
\text { trace } \\
0.23 \\
\text { none } \\
\cdots \ldots \\
0.03 \\
\mathrm{n} . \mathrm{d} \\
0.08 \\
\ldots . . \\
99.77\end{array}$ & $\begin{array}{r}0.748 \\
.125 \\
.021 \\
.061 \\
.343 \\
.231 \\
.017 \\
.039\end{array}$ & $\begin{array}{r}36.40 \\
\text { r2.94 } \\
8.27 \\
4.59 \\
\text { r } .44 \\
\text { r4.46 } \\
0.97 \\
3.01 \\
2.36 \\
3.94 \\
0.42 \\
\ldots .04 \\
\text { r.04 } \\
\ldots \ldots \\
\ldots . . \\
\text { n.d. } \\
\ldots . . \\
\ldots . . \\
99.84\end{array}$ & $\begin{array}{r}46.04 \\
\text { r } 2.23 \\
3.86 \\
4.60 \\
\text { ro.38 } \\
8.97 \\
2.42 \\
5.77 \\
2.87 \\
\ldots .64 \\
0.64 \\
\ldots .14 \\
\text { trace } \\
0.11 \\
\ldots . . \\
\text { trace } \\
0.48 \\
0.25 \\
99.76\end{array}$ \\
\hline
\end{tabular}

I. Fiordinal fiasconose (leucite-basanite). Fiordine, near Montefiascone, Vulsinian District. Washington, analyst.

II. Ouachital fiasconose (ouachitite). Dike r8, near Hot Springs, Arkansas. Eakins, analyst. J. F. Williams, Ann. Rep. Geol. Surv. Ark., r89o, II, p. 399.

III. Arrowal cascadose (minette). Dike near Arrow Peak, Highwood Mountains, Montana. Foote, analyst. L. V. Pirsson, Bull. U. S. G. S. No. 237, r9o5, p. I45.

Norm of $I$.

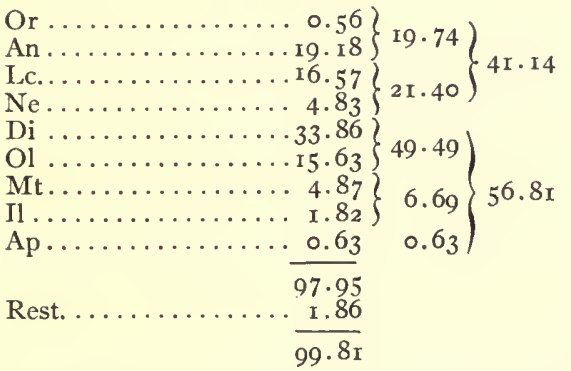

Ratios of $I$.

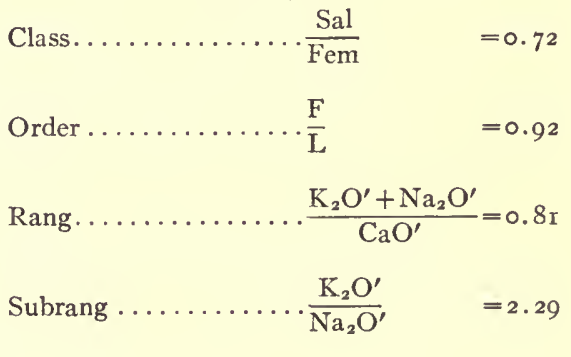

The analysis shown in $\mathrm{I}$ is remarkable as being the lowest in silica, alumina, and potash, and the highest in magnesia and lime, of any of the rocks analyzed. As

* Kemp, In Williams, Ann. Rep. Geol. Surv. Ark., II, 189o, pp. 393 ff. 
far as the norm goes, it is seen to be well within all the divisions, and this, as well as the normative mode of the type, its fresh and unaltered condition, caused its locality to be chosen for the name of the subrang rather than the locality root of the longerknown ouachitite. The chemical resemblance to the Arkansas rock is very close on the whole, though there are some differences of importance, notably in the silica, ferric oxide, lime, and magnesia. As this last rock is far from fresh, some of these differences may be ascribed to alteration, and its analysis is not very significant. The Montana rock, while closely similar to the Italian in silica, alumina, and iron oxides, differs notably in the figures for magnesia, lime, and the two alkalis, the lime being very considerably lower and the others higher than in $\mathrm{I}$. The differences are expressed in its position, III. 7. 2.3. It is of interest to note that of these closely related magmas, the fiordinal type, a lava flow, is almost strictly normative, the leucites shown by the norm appearing modally as such, while in the other two types, which occur as dikes, the mode is abnormative, the normative leucite and much of the normative olivine molecules* combining to form modal biotite, the rocks showing no leucite.

Mode.-Owing to the difficulty of determining the exact areas of the dark phenocrysts against the dark groundmass in the hand specimen, the amount of these could be determined only approximately, and the sections were not large enough to allow a representative area to be measured under the microscope. For these reasons the estimation of the mode by Rosiwal's method was abandoned, though sufficiently exact data were obtained to serve as some check on the results of the calculation of the mode from the norm. This offered no difficulties, all the potash going into leucite, the normative olivine being accepted as the modal, and the augite being assumed to have the usual composition. The amount of silica left to combine with the soda, after formation of the other modal minerals, is barely more than is requisite to form nephelite, the amount of albite being thus negligible, which agrees with the character of the plagioclase determined by the extinction angles as an almost pure anorthite. The very small amount of biotite was neglected in the calculation.

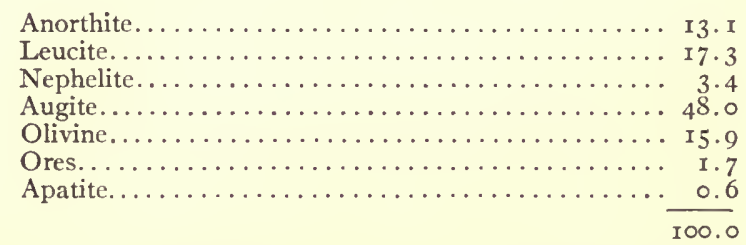

The mode is thus normative and the type would be described as a normative alferfemphyro-fiasconose.

Occurrence.-As far as known this type occurs only in the vicinity of Montefiascone, in the southeastern part of the Vulsinian District, especially near Fiordine. Some of the small valleys and dry stream beds here yield many well-formed, small crystals of both augite and olivine, derived from this rock. A somewhat similar type

* The ouachital type is apparently vitreous. 
is met with as a flow at the small hill of San Francesco, southeast of Ceccano, in the Hernican District. This, however, is lighter in color, though it presents much the same, but smaller, phenocrysts of olivine and augite. Its groundmass is much finer grained, with numerous small prismoids of augite, but little olivine, magnetite grains, and no biotite, embedded in a colorless base. This last is seen to be in part of plagioclase, in small, short laths, and in part isotropic, and possibly leucite. Unfortunately no analysis has, as yet, been made of this rock, the specimens of which are not very fresh, so that its assignment to this type is but provisional and somewhat doubtful.

Name.-The name of the subrang to which this type belongs, III. $7 \cdot 3 \cdot 2$, is derived from Montefiascone, the chief town in the neighborhood, and the typal adjective is derived from the hamlet of Fiordine, near which the type specimen analyzed was found.

The type from Fiordine has not yet been described, it would appear, but under the prevailing classifications there is no doubt that it would be called a leucitebasanite, though the amounts of leucite and feldspar are not very great. The type from San Francesco, near Ceccano, which is very doubtfully referred here, is called by Viola a feldspar-basalt, though he also mentions a leucite-basanite from San Francesco, apparently a distinct rock, of which I found no specimens. In the absence of an analysis, and in view of the difficulty as to deciding whether leucite is present or not in the fine-grained groundmass, the name feldspar-basalt would seem to be appropriate for this last occurrence, which, if found to be leucitic and by chemical analysis shown to belong to the subrang III. 7. 3. 2, could be called ceccanal fiasconose.

\section{FIORDINAL FIASCONOSE. III. 7.3.2.}

Megascopic characters.-Dark gray, compact, highly porphyritic. Augite phenocrysts abundant, 2 to $10 \mathrm{~mm}$., prismatic, equant and irregular, black or dark green. Olivine phenocrysts common, 2 to $20 \mathrm{~mm}$., equant, olive-green. Groundmass: dark gray, aphanitic.

$\therefore$ Microscopic characters.-Holocrystalline, magnophyric, dopatic. Phenocrysts: about 30 per cent, augite, olivine. Groundmass: about $7 \times$ per cent, xenomorphic granular, augite, leucite anorthite, olivine, biotite, magnetite, apatite.

Anorthite.-Groundmass: about I 3 per cent, anhedral, poikilitic areas, twinned, inclosing leucite, augite, olivine, magnetite.

Leucite.-Groundmass: about 17 per cent, 0.02 to 0.10 anhedral, equant, round sections, clear, free from inclusions, inclosed poikilitically in the anorthite.

Nephelite-Groundmass: about 3 per cent, anhedral, interstitial.

Augite.-Phenocrysts: about 25 per cent, 0.05 to $20.0 \mathrm{~mm}$., euhedral to subhedral, prismatic, equant, and irregular, often fragmentary, pale gray, few inclusions of magnetite. Groundmass: about 25 per cent, 0.02 to $0.50 \mathrm{~mm}$., anhedral, equant and prismatic, very pale gray.

Olivine.-Phenocrysts: about to per cent, 0.5 to $20 \mathrm{~mm}$., subhedral to anhedral, equant and tabular, colorless, only slightly altered on edges, few inclusions of magnetite. Groundmass: about 5 per cent, 0.05 to $0.50 \mathrm{~mm}$., euhedral to subhedral, equant, prismatic and tabular, colorless, very slightly altered.

Biotite.-Groundmass: about 2 per cent, 0.1 to $0.5 \mathrm{~mm}$., anhedral, as irregular, interstitial patches, often inclosing augite, olivine, and magnetite poikilitically, brown.

Magnetite.-Groundmass: about 2 per cent, 0.01 to $0.05 \mathrm{~mm}$., anhedral, equant. 
A patite.-Groundmass: about I per cent or less, 0.02 to $0.05 \mathrm{~mm}$., subhedral, prismatic, difficult to detect.

Chemical composition and norm as on p. 127 .

Type specimen from Fiordine, near Montefiascone, Vulsinian District.

\section{8. 2. 2. Romal Albanose [Leucitite, Rome Type].}

Megascopic characters. - The rocks which belong to this type are very uniform in character megascopically, dense, dark-gray or black basalts, wholly aphyric or almost wholly so, the phenocrysts being very rare, small leucites and augites. The texture is aphanitic, no distinction between dark and light mineral particles being visible to the naked eye or with the hand lens.

Microscopic characters. - In thin section this type presents much the same features as those described under galeral braccianose, except that the small amount of feldspar visible in that is here totally absent or almost so. The texture is holocrystalline, and the fabric a more or less clathrate one, with the characteristic round leucites, though transitions to the xenomorphic granular fabric of the hernical and saccal types are not rare. These are somewhat difficult to classify with certainty, but the general rule that microphenocrysts of leucite characterize the galeral and romal types, and microphenocrysts of augite the hernical and saccal, is a useful diagnostic character. The small ( 0.05 to $0.2 \mathrm{~mm}$.) round leucites are abundant, but relatively not as much so as in the corresponding type of braccianose or vesuvose. Skeleton development is rather common. Augite microphenocrysts are not abundant, and assume the form of stout subhedral or anhedral prismoids, of the usual color and optical characters. The greater part of this mineral is in the form of minute prisms and grains between the leucites, as already described. Magnetite grains are always present, in varying but small amounts, and the same is true of apatite. There is a small quantity of colorless, interstitial base, the exact study of which is difficult, owing to the felted character of the microgroundmass. In places it appears to be plagioclase, again nephelite or glass, though these are rarer, but the amount in any case is small. In some specimens there are small patches of yellowish, interstitial melilite, marking a transition to the boval type, but in typical ones this is negligible or wholly absent. In some instances there may be a trifling amount of interstitial brownish biotite. Olivine is sometimes present, in rare small grains, and again wholly absent.

Chemical composition.-An analysis of a characteristic specimen of this type was made and is given below in I. There is also given for comparison in II an analysis of the coarse granular type from the Highwood Mountains (missourite), which is magmatically very close to the dofemane class, where it was formerly placed,* but which the more accurately calculated norm of Pirsson $\dagger$ has shown to be just across the border in salfemane, and hence in albanose. To this type the name "missoural albanose" may be applied, in recognition of its name in the prevailing systems.

* Washington, Prof. Paper, U. S. Geol. Surv. No. I4, I903, p. 355.

$\uparrow$ Pirsson, Bull. U. S. Geol. Surv. No. 237, 1905, p. I20. 
Chemical Composition of Romal Albanose [Leucitite].

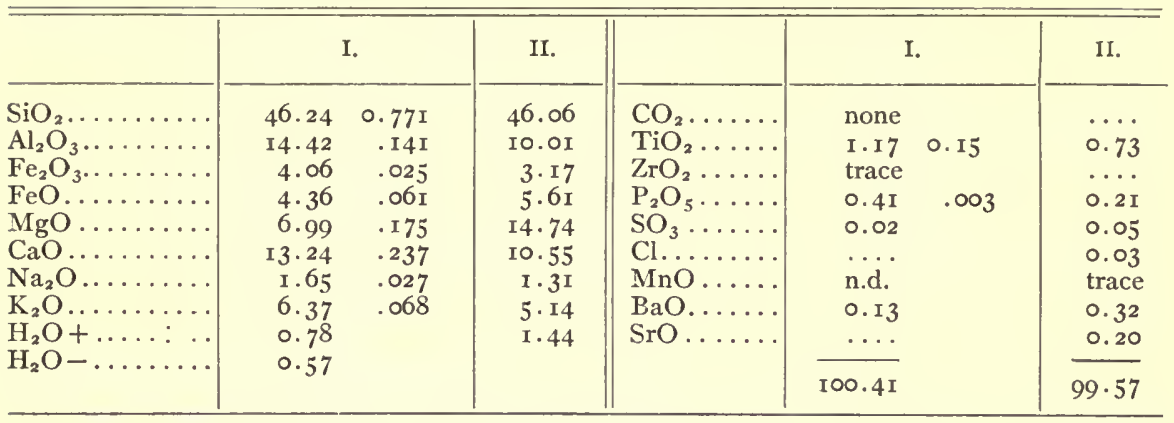

I. Romal albanose [leucitite]. Upper flow of Monte Rado, east of Lake Bolsena, Vulsinian District. Washington, analyst.

II. Missoural albanose [missourite]. Shonkin Creek, Highwood Mountains, Montana. Hurlbut, analyst. Pirsson, Bull. U. S. G. S. No. 237, 1905, p. I I 7 .

Norm of $I$.

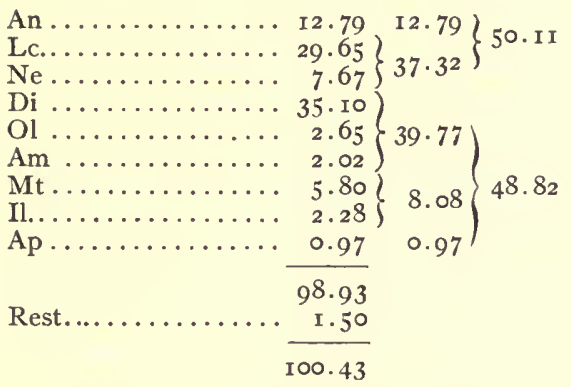

Ratios of $I$.

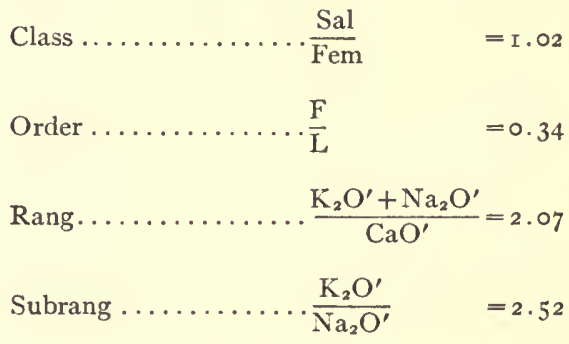

The analysis in I resembles in general the preceding ones of types of braccianose, which have also been called leucitite, or leucite-tephrite, but differs in the somewhat lower alumina and potash, and in the higher lime. Comparison with the missoural type shows the general resemblance and at the same time the much more femic character of the latter (the norm of which is published by Pirsson in the paper cited). This difference is brought out by comparison of the ratios, especially those for class, which in I is almost exactly that of the center point, while in II it is almost exactly at the border between Classes I and II. Otherwise both are well within the other divisions, the ratios of the alkalis being almost identical.

Mode.-For the same reasons that have obtained before it was impracticable to measure the mode of this type optically. It was calculated from the norm as usual, the only new assumption being that the small amount of melilite, known to be present by microscopical study and indicated by the norm, had the composition of that of Monte Somma as analyzed by Bodländer.* In II is given the mode of missoural albanose [missourite] calculated by Pirsson. $\dagger$

* Bodländer, Neu. Jahrb. I, I893, p. I7.

$\dagger$ Pirsson, loc. cit., p. II 8 . 


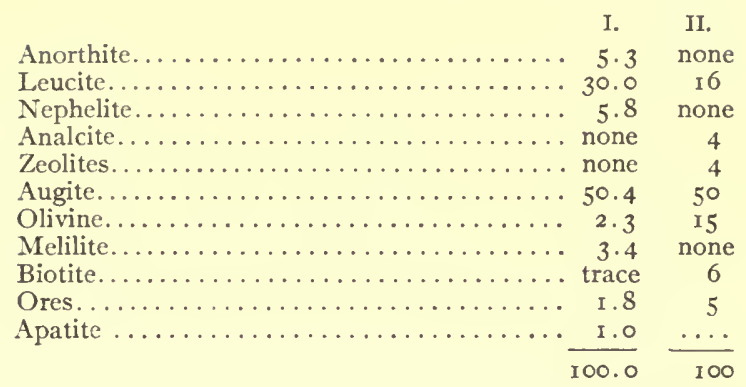

The figures of I correspond with the appearance in thin section, and may be regarded as approximately correct. As compared w th the missoural type the amount of augite in each is the same, and the nephelite of $I$ is replaced by analcite and zeolites in II. The chief differences are found in the much higher leucite and lower olivine of I, as well as in the presence in this of anorthite and melilite and in II of biotite, all in small amounts. It is clear that the mode of $I$ is practically normative, the readjustments needed to form augite and melilite being negligible, while the mode of II is more abnormative, about one-quarter of the normative leucite going into biotite.* The romal type may then be described as normative salphyri-albanose, while the missoural type would be a biotitic grano-albanose.

Occurrence.-This type is abundant in certain districts, especially in the Vulsinian, the Sabatinian, and the Latian. In the first some localities are near San Lorenzo and at the cemetery of Bolsena, at the upper flow in the quarry on the west side of Monte Rado, and at the Ponte della Regina and Madonna del Borgale, southeast of Lake Bolsena. In the Sabatinian District the most prominent locality is the crater of Trevignano, on the north shore of Lake Bracciano. Most of the extensive flows south of the lake with a similar habit belong to braccianose, as we have seen, but at Casaccia, near the Anguillara station, this type of albanose occurs. In the Latian District the type is common, and some localities are Monte Cavo, Grotta Ferrata, and the Villa Aldobrandini, near Frascati.

Name.-The name of the subrang is derived from that of the Alban Hills, in which this magma is represented abundantly. That of the type is derived from that of the region, of which this is one of the most characteristic types.

In the prevailing systems these rocks have been uniformly called leucitites, and this may be regarded as their proper name, though the term should logically, it would seem, be reserved for rocks composed wholly of leucite or almost so. $\dagger$

ROMAL ALBANOSE. III, 8, 2, 2.

Megascopic characters.-Very dark gray or black, compact, aphyric, or with very rare phenocrysts of leucite and augite. Groundmass aphanitic.

* As 4.9 per cent of the normative leucite is present in the biotite it would seem that the modal amoun of biotite is really somewhat more than is here calculated.

† Cf. Cross, Am. Jour. Sci., IV, I897, p. 137; and Washington, ibid., IX, 1900, p. 54. 
Microscopic characters.-Holocrystalline, microporphyritic, clathrate microfabric. Microphenocrysts: about 50 per cent, leucite, augite. Microgroundmass: about $\$ 60$ per cent, augite, anorthite, olivine, magnetite, apatite, sometimes melilite and biotite.

Anorthite.-Groundmass: about 5 per cent, anhedral, interstitial, difficult to distinguish.

Leucite.-Microphenocrysts: about 30 per cent, 0.05 to $0.20 \mathrm{~mm}$., subhedral to anhedral, equant, round sections, sometimes skeleton forms, inclusions common, very small, mostly of glass or augite, regularly arranged.

Nephelite.-Groundmass: about 5 per cent, anhedral, interstitial areas, difficult to detect.

Augite.-Microphenocrysts: about 20 per cent, 0.10 to $0.30 \mathrm{~mm}$., anhedral, prismatic, or fragmentary, pale yellowish-gray, inclusions few. Microgroundmass: about 30 per cent, 0.02 to $0.05 \mathrm{~mm}$., anhedral, prismatic to equant, very pale yellowish-gray, arrangement partly tangential around the leucites.

Olivine.-Groundmass: 2 to $\circ$ per cent, 0.05 to 0 . $10 \mathrm{~mm}$., anhedral, equant.

Biotite. - I to o per cent, anhedral, small interstitial areas.

Melilite.-Groundmass: 3 to o per cent, anhedral, interstitial areas.

Magnetite.-Groundmass: about 2 per cent, 0.01 to $0.05 \mathrm{~mm}$., anhedral, equant.

A patite.-About I per cent, 0.03 to $0.05 \mathrm{~mm}$., subhedral, prismatic.

Chemical composition and norm as on p. r $3 \mathrm{r}$.

Type specimen from Monte Rado, east of Lake Bolsena, Vulsinian District.

\section{8. 2. 2. Saccal Albanose [Leucitite, Sacco Type].}

Megascopic characters.-In the hand specimen this type resembles closely that just described, being dense and very dark gray, and almost wholly aphyric, the very rare phenocrysts, when present, being of leucite and augite. In examining a series of specimens of the two, however, it is noticed that the color of the romal type is distinctly darker as a rule than that of the saccal, though both are so dark and aphanitic as to be called basalts in the field.

Microscopic characters. - To this type the description of the hernical braccianose applies very well, except as to the feldspar, which is here scarcely visible. The rock is holocrystalline and with the same xenomorphic granular fabric. There are fairly numerous microphenocrysts of augite, from 0.2 to $0.5 \mathrm{~mm}$. long, in stout, subhedral prismoids and equant anhedral grains. They are of the usual pale-gray color, in some specimens with a zonal structure, slightly darker and greenish toward the center, and almost wholly free from inclusions. This augite has been studied by Viola,* though the variety examined by him is decidedly greener and apparently richer in the ægirite molecule than that shown in my sections. He gives the extinction angle $\mathrm{c} \wedge \mathrm{r}$ in the small non-pleochroic crystals as $45^{\circ}$, while $I$ obtained $42^{\circ}$ for $\mathbf{a} \wedge \mathfrak{a}$. To this pyroxene he gives the name of fedorowite. As an analysis of typical augite from the rocks of the Roman Region was desirable, a specimen of this type was chosen for examination from near Ticchiena, north of Frosinone, in the Hernican District. The rock powder used for the chemical analysis of the rock was digested for some hours in warm dilute hydrochloric acid, to which a little hydrofluoric acid was added. The residue was washed out with dilute solution of sodium carbonate and the process repeated, but without hydrofluoric acid, the final residue being, of course, washed perfectly free from all soluble salts. This process would

* C. Viola, Neu. Jahrb., 1899, I, pp. 102-21. 
naturally dissolve all the leucite, olivine, melilite, magnetite, apatite, and anorthite, which are the only other minerals present, and would have only a slight effect on the augite, removing the outer portions. A few larger augites in the specimen were zonal, but the majority of them and all the small ones were quite uniform in character from center to periphery. The analysis resulted as follows:

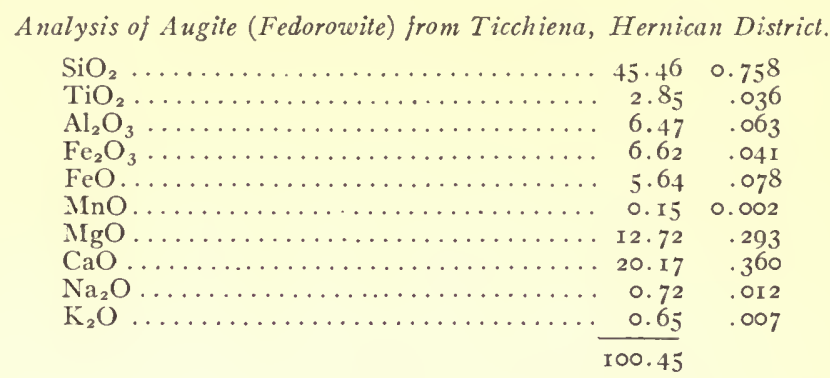

Combining these into the respective amounts of pyroxene molecules, we get the following percentage composition:

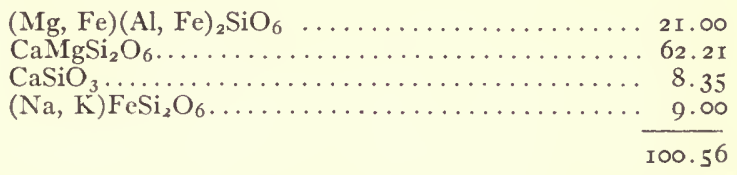

That is, the pyroxene has the molecular composition $85(\mathrm{Mg}, \mathrm{FeAl}, \mathrm{Fe})_{2}$ $\mathrm{SiO}_{6} .288 \mathrm{CaMgSi}_{2} \mathrm{O}_{6} .72 \mathrm{CaSi}_{2} \mathrm{O}_{3} \cdot 19(\mathrm{Na}, \mathrm{K}) \mathrm{FeSi}_{2} \mathrm{O}_{6}$, or more roughly $4(\mathrm{Ca}, \mathrm{Mg})$ $\mathrm{SiO}_{3}+(\mathrm{Mg}, \mathrm{Fe})(\mathrm{Al}, \mathrm{Fe})_{2} \mathrm{Si}_{2} \mathrm{O}_{6}$ with less than 1:20 of the acmite molecule. Calculating the norm of this pyroxene as if it were a rock, we get:
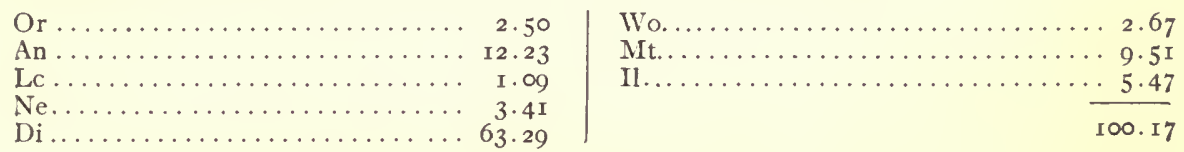

It is thus seen that salic constituents make up about one-fifth of the augite, and may thus introduce very notable differences between the norm and mode in many cases.

It may be mentioned, by the way, that the norm calculated above was used in readjusting the figures of the norm $\mathbf{s}$ to calculate the mode $\mathbf{w}$, as this procedure was found to be more easy and simple than that of ratios of the different chemical constituents as compared with the data in the assumed mineral composition, as explained elsewhere.*

Between the larger augites, and either between or inclosing the smaller ones, are small formless or sometimes rounded individuals of leucite, which acts as an interstitial cement to a large extent, though the individuals are small and not poikilitic in the usual sense of the term. With these leucites are small areas of melilite in most 
of the specimens, the amount of this varying somewhat and never being large. There is also a very little soda-lime feldspar, in minute, stout prismoids, generally a few grains of olivine, and small grains of magnetite and needles of apatite.

Chemical composition.-Two analyses were made of rocks of this type, both specimens coming from the Hernican District. With them are given two other analyses of rocks from this area, though they are not altogether worthy of confidence.

Chemical Composition of Saccal Albanose [ Leucitite].

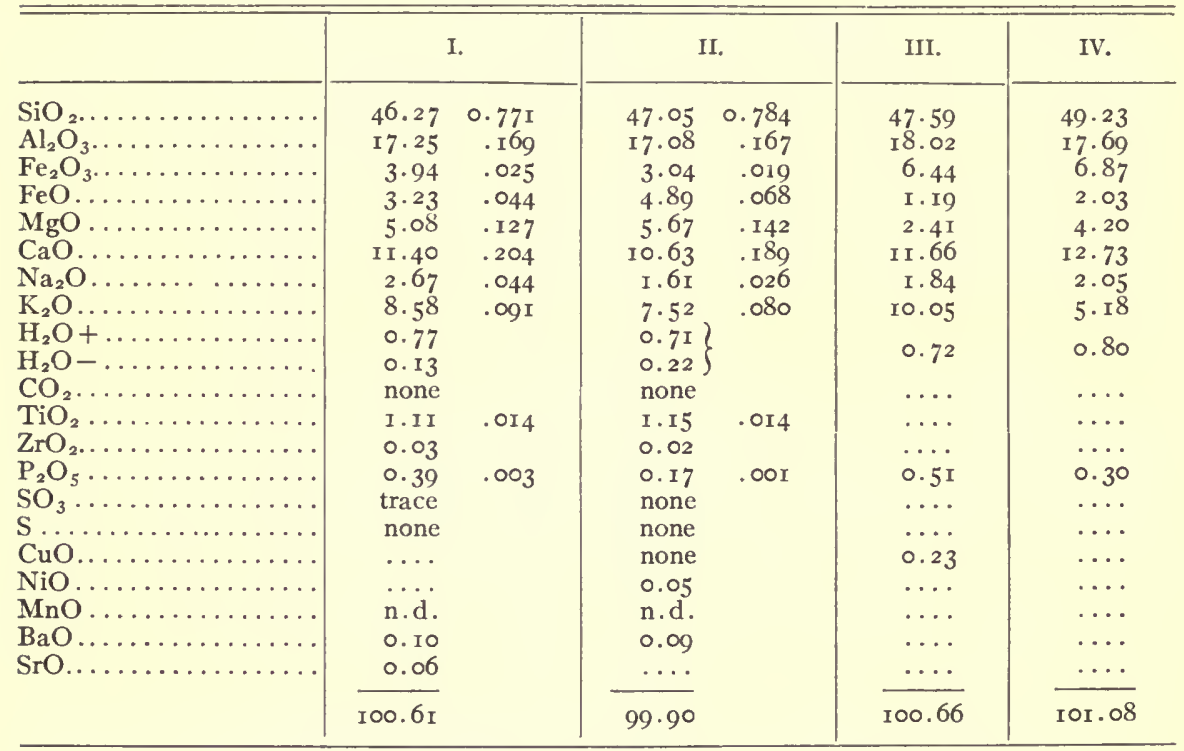

I. Saccal albanose [leucitite]. Ticchiena, near Frosinone, Hernican District. Washington, analyst.

II. Saccal albanose [leucitite]. Pofi, Hernican District. Washington, analyst.

III. "Leucitite." Pof, Hernican District. Speciale, analyst. Cf. Viola, loc. cit., p. 100.

IV. "Leucite-basalt." Morolo, Hernican District. Viola, analyst. Viola, Neu. Jahrb., I899, I, p. 97.

\section{Norm of $I$.}

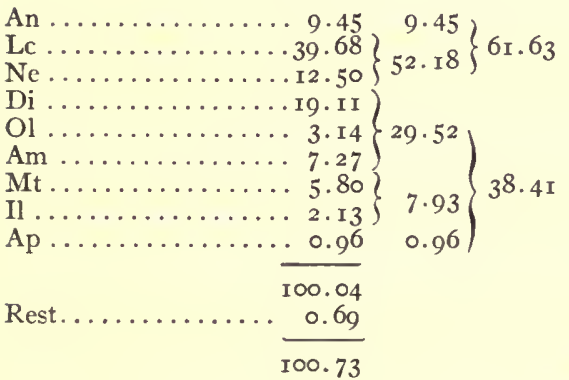

Norm of $I I$.

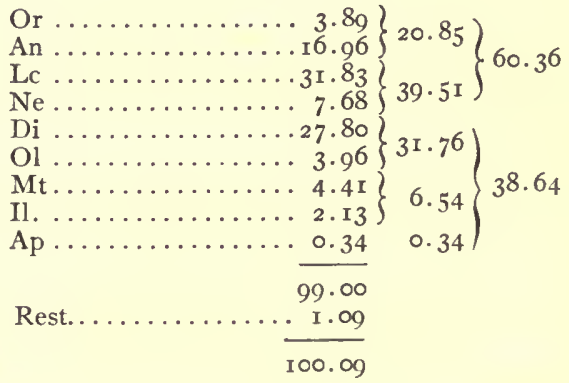




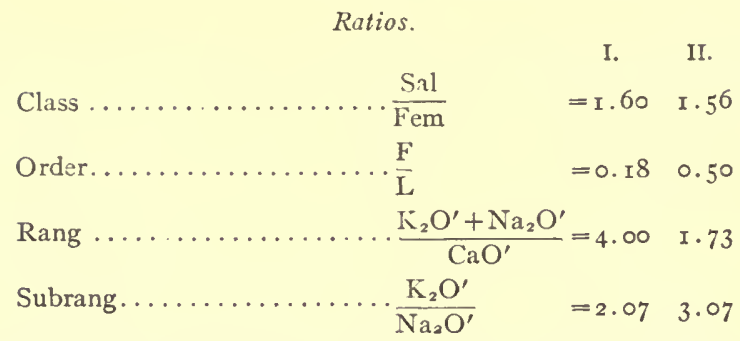

Analyses I and II are much alike, the differences being of small importance. It will be noticed that their norms are unlike in that the norm of I shows considerable akermanite, while that of II shows no akermanite, but a little orthoclase, and considerably more anorthite and less leucite. These are explained by the slightly lower silica and higher lime and potash of I. The two resemble the analysis of the romal albanose (p. I3O), but not as closely as they do each other. In the former type the alumina and potash are considerably lower and the lime and magnesia higher.

The analyses in III and IV are not very reliable. It may suffice to point out, as very doubtful features, the high alumina and low magnesia, the iron oxides, and the high potash, as well as the presence of copper in III. Copper was especially looked for in my analysis of the Pofi rock, but without finding even a trace, and it is probable that the copper reported by Speciale is in reality platinum derived from the vessels used. In IV may be noted the somewhat high silica, the iron oxides, the high lime, and the unsatisfactory summation. It may be noted that the magma represented by this analysis would fall in II. 6. $3 \cdot 3,{ }^{*}$ an improbable position for such a highly leucitic and feldspar-poor rock.

Mode.-Neither of the specimens lent themselves to microscopic measurement, on account of the fineness of the grain and the difficulty of estimating the leucite and interstitial substance. As the simpler one the mode of the Pofi rock will be discussed first. This calculates out as follows:

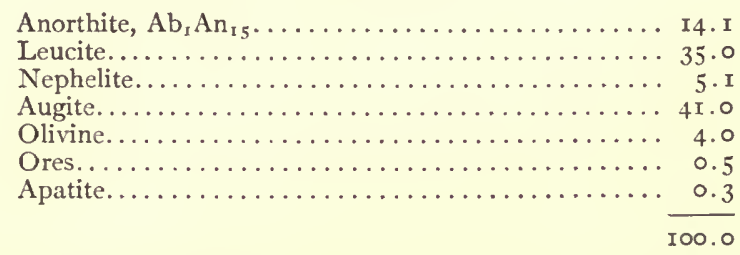

This mode corresponds well with the appearance of the thin section, though the amount of anorthite is rather larger than one would expect. The adjustments are of comparatively slight importance, chiefly to form the augite, and those necessary to change orthoclase to leucite, with consequent formation of a little albite and less nephelite. The mode therefore may be regarded as normative and the rock described as normative alferphyri-albanose.

* Washington, Prof. Paper, U. S. Geol. Surv. No. 14, rgo3, p. зоr. 
The mode of the Ticchiena rock was likewise easy to calculate from the norm, but the results do not correspond as well with the microscopic appearance. This is due to the amount of normative akermanite present, which demands the formation of some 12 per cent of melilite, and there does not appear to be nearly so much of this actually, though a little undoubtedly exists. There is no more normative mineral present from which we can abstract any silica to change the akermanite in part to wollastonite to form augite, and there is no reason for thinking that the analysis is defective to the serious extent implied by the normative presence of so much akermanite and so little modal melilite. As the grain is very fine, except for the rather numerous augite microphenocrysts, it may well be that more melilite is actually present than would appear in the section. However this may be, the results of the calculation are as follows:

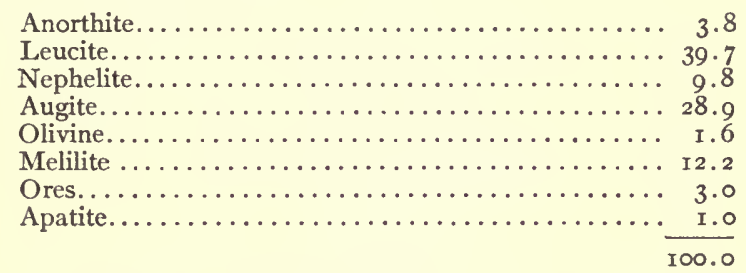

This mode corresponds well with the thin section as far as the amounts of anorthite, leucite, olivine, ores, and apatite go, and that of augite is fairly close, though the apparent amount is somewhat greater. The main variations from the thin section are in the higher nephelite and melilite, the latter of which has been spoken of above. The mode is a normative one on the whole, but the implied presence of so much melilite, even though discoverable with difficulty, would suggest that this rock be distinguished from that of Pofi. This could be done by erecting it into a distinct type, whch might be called the ticchienal, and distinguished from the true saccal by the presence of melilite, and from the boval type to be described next, which is also rich in melilite, by the phenocrystic character of the augite and the less obvious melilite. But to avoid an undue number of type names this rock will, for the present, be considered to be of the same type as the Pofi one, that is, saccal.

Occurrence.-This type of albanose is by no means so common as the romal, and specimens could be identified with certainty only from the Hernican District, at the two localities cited, from the Vulsinian, where it forms the flow on the summit of Monte Rado, above that mentioned on pp. 131 and 132, and in the Sabatinian at the Fosso San Celso, on the south shore of Lake Bracciano.

Name.-The derivation of the subrang name has been already discussed. The typal adjective is derived from the Sacco River, in the valley of which rocks of this type are prominent.

In the prevailing classifications these rocks are for the most part to be regarded as leucitites, though the small amount of plagioclase in some specimens has suggested the name of leucite-tephrite as the more appropriate. The smallness of the quantity of olivine wnuld render the term leucite-basanite inappropriate. 
SACCAL ALBANose. III. 8. 2. 2.

Megascopic characters.-Very dark gray, compact, aphyric, or with very rare phenocrysts of augite and leucite, aphanitic.

Microscopic characters.-Holocrystalline, microporphyritic. Microphenocrysts: about 20 per cent, augite. Microgroundmass: about 80 per cent, leucite, augite, anorthite, nephelite, olivine, magnetite, apatite, usually melilite.

Anorthite.-Four to ro per cent, anhedral, part as very small prisms, part interstitial, sometimes difficult to detect.

Leucite.-About 35 per cent, 0.03 to $0.10 \mathrm{~mm}$., anhedral, equant, usually round sections, sometimes irregular, clear, inclusions few.

Nephelite.-About 5 per cent, anhedral, interstitial cement.

A ugite.-Microphenocrysts: about 20 per cent, 0.2 to $0.5 \mathrm{~mm}$., subhedral to anhedral, prismatic, often fragmentary, pale greenish-gray, sometimes zonal. Microgroundmass: about 30 per cent, 0.02 to $0.2 \mathrm{~mm}$., anhedral, prismatic and equant, very pale greenish-gray.

Olivine. -4 to o per cent, 0.05 to $0.10 \mathrm{~mm}$., anhedral to subhedral, equant, colorless.

Melilite. $\rightarrow$ to 5 per cent, anhedral, as formless, interstitial areas, yellowish.

Magnetite.-About 2 per cent, 0.02 to $0.05 \mathrm{~mm}$., anhedral, equant.

A patite.-About I per cent, 0.03 to $0.10 \mathrm{~mm}$., subhedral, prismatic.

Chemical composition and norm as on p. 135 .

Type specimens from Pofi and Ticchiena, Hernican District.

\section{8. 2. 2. Boval Albanose [Leucitite, Bove Type, Cecilite].}

Megascopic characters. - This type does not differ in the hand specimen, to any marked extent, from those just described. The rocks are dense, very dark gray, in this more like the hernical type, and are aphanitic. They are for the most part entirely aphyric, but may carry very rare phenocrysts of leucite or augite, as in the other cases. Some of them, as specimens from Capo di Bove, show a peculiar, very faint mottled appearance, in patches of very slightly greenish-gray mingled with the general dark gray. This has been noticed in other melilite rocks, as well as in more ordinary basalts, and seems to be due to incipient weathering.

Microscopic characters. - This type is wholly holocrystalline, and with a peculiar fabric which resembles the clathrate described above, but differs in the greater thickness of the spaces between the round leucite spots.

Small ( 0.05 to 0.20$)$, round leucites are abundant, making up about one-half of the rock. Many of them are subhedral, showing some crystal planes, while others are quite anhedral and with round outlines. They very commonly carry small, mostly black, inclusions, which are arranged radially or as circular lines of dots. Birefringence is rather weak but unmistakable.

Between these are the other constituents. There is a good deal of augite, of the usual pale-gray color, which is largely in formless, interstitial masses, but occasionally subhedrally prismatic. This constitutes about one-quarter of the rock. Melilite is also present in very considerable amount, but less than the augite, in similar interstitial areas, usually poikilitic. The mineral is of a very pale yellowishgray, with high relief, shows the usual blue-gray color between crossed nicols, and has often the well-known "pflock" structure. There are also similar areas of 
clear, colorless nephelite, in about the same amount as the melilite, and rare subhedral prisms of this mineral are seen here and there.

As accessories occur very small anhedral grains of olivine, few small, stout laths of anorthite, magnetite grains, and apatite needles. In some specimens there are also a few small flakes of brownish biotite.

Chemical composition.-An analysis was made of this type, which has been already published in incomplete form. In column II is given the only other analysis so far made of this well-known rock.

Chemical Composition of Boval Albanose [Melilitic Leucitite, Cecilite].

\begin{tabular}{|c|c|c|c|c|c|c|}
\hline & & & II. & & I. & II. \\
\hline 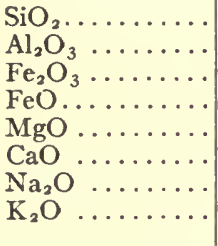 & $\begin{array}{r}45 \cdot 99 \\
16.56 \\
4.17 \\
5 \cdot 38 \\
5 \cdot 30 \\
10.47 \\
2.18 \\
8.97\end{array}$ & $\begin{array}{r}0.767 \\
.162 \\
.026 \\
.075 \\
.133 \\
.188 \\
.035 \\
.096\end{array}$ & $\begin{array}{r}45.93 \\
\text { 18.72 } \\
\text { n.d. } \\
\text { 10.68 } \\
5.67 \\
10.57 \\
\text { I.68 } \\
6.83\end{array}$ & $\begin{array}{l}\mathrm{H}_{2} \mathrm{O}+\ldots \\
\mathrm{CO}_{2} \ldots \ldots \\
\mathrm{TiO}_{2} \ldots \ldots \\
\mathrm{P}_{2} \mathrm{O}_{5} \ldots \ldots \\
\mathrm{MnO}^{\mathrm{InO}} \ldots \ldots \\
\mathrm{BaO} \ldots \ldots \\
\mathrm{SrO} \ldots \ldots\end{array}$ & $\begin{array}{ll}0.45 & \\
\text { none } & \\
0.37 & 0.005 \\
0.56 & .004 \\
\text { n.d. } & \\
0.25 & \\
\text { none } & \\
\text { I00.65 } & \end{array}$ & $\begin{array}{c}0.59 \\
\ldots \\
\ldots \ldots \\
\ldots \\
\ldots \\
\ldots \\
\ldots \ldots \\
100.67\end{array}$ \\
\hline
\end{tabular}

I. Boval albanose [leucitite]. Capo di Bove, Latian District. Washington, analyst. Cf. Am. Jour. Sci., IX, I900, p. 53 .

II. Boval albanose [leucitite]. Capo di Bove, Latian District. Bunsen, analyst. Roth, Beitr. Petrog., I869, p. cii, No. 3 I.

Norm of $I$.

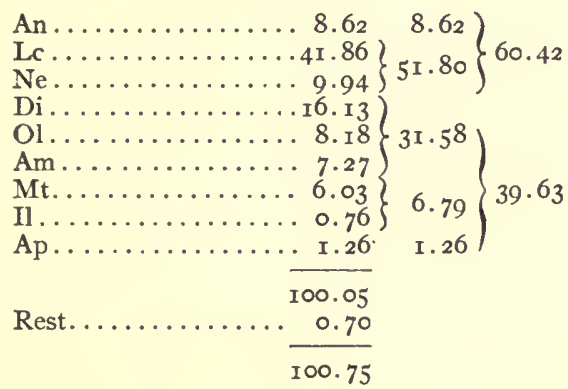

Ratios of $I$.

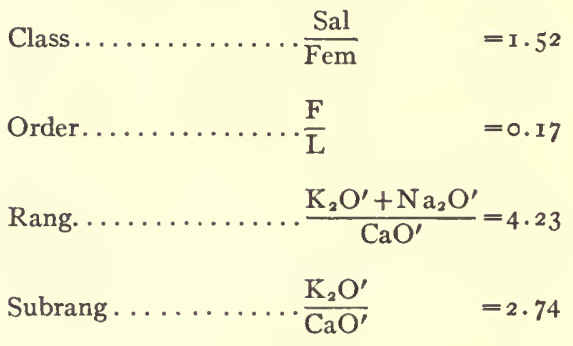

Analysis I resembles those of the two preceding types of albanose, though it is decidedly more like that of the rock from Ticchiena.

Mode.-The sections of this type were fairly well adapted to measurement under the microscope, though it was often somewhat difficult to distinguish between the colorless minerals. The results of such a study are found below. The mode was readily calculated, the usual assumptions being made as to the composition of the augite and melilite. 


\begin{tabular}{|c|c|c|c|c|c|c|c|c|}
\hline \multirow{8}{*}{ 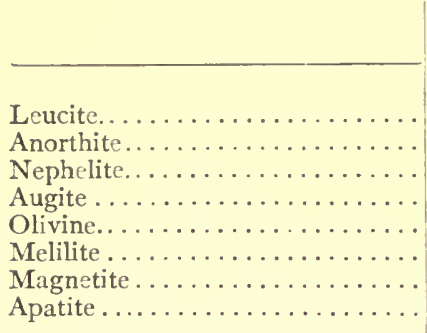 } & \multirow{4}{*}{$\begin{array}{r}\text { Calculated. } \\
\left.\begin{array}{r}41.9 \\
3.6 \\
7.3\end{array}\right\}\end{array}$} & \multicolumn{7}{|c|}{ Measured. } \\
\hline & & \multirow{3}{*}{$\begin{array}{r}\text { Units } \\
2,055 \\
460\end{array}$} & \multirow{3}{*}{\multicolumn{2}{|c|}{$\begin{aligned} & \text { Vol. } \% . \\
= & 44.9> \\
= & \text { IO. I > }\end{aligned}$}} & \multicolumn{2}{|c|}{ Sp.gr. } & \multirow{3}{*}{$\begin{array}{r}\text { I I 2. I } \\
26.3\end{array}$} & $\begin{array}{l}\text { Wt. } \% \text {. } \\
38.6\end{array}$ \\
\hline & & & & & & & & \multirow{2}{*}{$9 \cdot 1$} \\
\hline & & & & & $\times 2.0$ & $=$ & & \\
\hline & $\left.\begin{array}{r}22.6 \\
6.8\end{array}\right\}$ & I, 493 & $=$ & 32.7 & $\times 3.3$ & $=$ & 107.9 & $37 \cdot 2$ \\
\hline & 12.6 & 403 & $=$ & 8.8 & $\times 2.9$ & $=$ & $25 \cdot 5$ & 8.8 \\
\hline & 4.0 & 160 & $=$ & $3 \cdot 5$ & $\times 5.2$ & $=$ & 18.2 & 6.3 \\
\hline & I. 2 & & & & & & & \\
\hline & 100.0 & $4,57 \mathrm{I}$ & & 100.0 & & & 290.0 & 100.0 \\
\hline
\end{tabular}

The correspondence between these is not very close, though they agree in the main features. It would seem that overlapping has entered to a considerable extent, and possibly that the section examined was not quite as rich in melilite as the mass of the rock. On the whole the mode is normative, but the notable amount of melilite should be considered, and the rock may therefore be described as a normative melilitic grani-albanose.

Occurrence.-This type is rather common in the Latian District, not only at the well-known locality of Capo di Bove, but at Tusculum, near Grotta Ferrata, and elsewhere. Rocks which may be considered to be of the same type are also found at Poggio Selva and as blocks in tuff at Madonna d'Oro, both near Montefiascone in the Vulsinian District, and at the fountain west of Trevignano in the Sabatinian.

Name.-The type name is derived from the type locality of Capo di Bove, between Rome and the Alban Hills.

In the prevailing systems this type has been uniformly included among the leucitites, of which it is always cited as the most prominent example. In view of the very considerable amount of melilite, and the interest due this mineral on account of its rarity, it might be well to revive Cordier's* old name "cecilite," derived from the tomb of Cecilia Metella above the quarry of Capo di Bove, for the melilitebearing leucitites. Such a distinction would be advisable, since the great majority of the leucitites are free from melilite, as we have seen. The term "cecilal" can not well be used for the type adjective in the quantitative system, since the root "cecil" is already in use in the subrang cecilose (V. $\left.\mathrm{I}^{\mathrm{x}} \cdot \mathrm{I}^{2} \cdot 2\right)$.

BOVAL ALBANOSE. III. 8. 2. 2.

Megascopic characters.-Very dark gray, compact, aphyric, but sometimes with very rare phenocrysts of leucite and augite, aphanitic. Occasionally slightly mottled if not quite fresh.

Microscopic characters.-Holocrystalline, granular, partly poikilitic, leucite, augite, melilite, nephelite, olivine, anorthite, magnetite, apatite.

Anorthite.-About 4 per cent, 0.05 to 0 . ro mm., subhedral, tabular, twinned.

* Cordier, Description des Roches, Paris, 1868, p. 117. Cf. C. R. VIII Cong. Geol. Int., Paris, 1901, p. 105:

Leucite.-About 40 per cent, 0.05 to $0.20 \mathrm{~mm}$., subhedral to anhedral, equant, round sections, clear, inclusions common, small, usually black, regularly arranged, skeleton forms not infrequent.

Nephelite.-About 7 per cent, anhedral, interstitial areas. 
A ugite.-About 25 per cent, 0.05 to $0.50 \mathrm{~mm}$., subhedral to anhedral, partly in prismatic and equant, partly irregular and interstitial; pale gray, few inclusions.

Olivine.-About 7 per cent, 0.05 to $0.10 \mathrm{~mm}$., anhedral, equant.

Melilite.-About I 2 per cent, anhedral, interstitial patches, sometimes poikilitic about the smaller crystals, areas up to $2 \mathrm{~mm}$. in diametcr, "pflock" structure common, pale yellowish.

Magnetite.-About 4 per cent, 0.02 to $0.05 \mathrm{~mm}$., anhedral, equant.

A patite.-About I per cent, 0.03 to $0.08 \mathrm{~mm}$., subhedral, prismatic.

Chemical composition and norm as on p. 139 .

Type specimen from Capo di Bove, Latian District,

\section{Correlation of Types.}

As the types described in the preceding pages are numerous, and as the characteristics on which they are based differ in certain respects from those which obtain in the prevailing systems, it will be not amiss to point out briefly the chief features in which those of the quantitative system resemble or differ from each other, and also to indicate the correlation between them and those of the prevailing systems.

Types of the Quantitative System.

In correlating the types from the point of view of the quantitative system alone we may devote special attention to the modal and textural characters denoted by the typal adjective, though the magmatic character, as expressed by the subrang name, must also be considered. It will have been noticed that the same type adjective is applied to different subrangs. This has been the case when the subrangs resemble each other quite closely, as with vulsinose, pulaskose, and monzonose, or with vesuvose and albanose, and when the modal and textural characters of the representatives of the different subrangs are so much alike that very close study, especially from the chemical side, is necessary to distinguish between the rocks. Thus only a chemical analysis or careful optical measurements can distinguish between the three types of bolsenal vulsinose, pulaskose, and monzonose, the modal characters differing but slightly and the textural being practically identical. By this plan of a single type adjective applicable to several subrangs the great similarity between such types is made manifest and the number of new terms is lessened.

From the modal and textural points of view types may resemble or differ from each other either in respect to mode, or to texture, or to both together, and they may also form series of types with members which are homologous modally or texturally. This is illustrated by the following examples:

\begin{tabular}{c|c|c|c}
\hline \multicolumn{1}{c|}{ I. 5. 1.3. } & I. 5. 2. 2. & II. 5.2.2. & II. 5. 2. 3. \\
\cline { 1 - 2 } $\begin{array}{l}\text { Ischial phlegrose. } \\
\text { Cumal phlegrose. }\end{array}$ & $\begin{array}{l}\text { Arsal vulsinose. } \\
\text { Bolsenal vulsinose. }\end{array}$ & $\begin{array}{l}\text { Arsal ciminose. } \\
\text { Fiescolal ciminose. }\end{array}$ & $\begin{array}{l}\text { Arsal monzonose. } \\
\text { Bolsenal monzonose. }\end{array}$ \\
\hline
\end{tabular}

\begin{tabular}{l|c|c}
\hline \multicolumn{1}{c|}{ II. 5. 2. 2. } & II. 6.2.2. & II. 7.2.2. \\
\hline $\begin{array}{l}\text { Viterbal ciminose. } \\
\text { Bagnoreal ciminose. } \\
\text { (Orvietal ciminose.) }\end{array}$ & $\begin{array}{l}\text { Foglianal vicose. } \\
\text { Bagnoreal vicose. } \\
\text { Orvietal vicose. }\end{array}$ & $\begin{array}{l}\text { Vesbal braccianose. } \\
\text { Scalal braccianose. } \\
\text { Galeral braccianose. }\end{array}$ \\
\hline
\end{tabular}


In both sets as we read down there is a progressive diminution in the size and abundance of the phenocrysts, here assumedly all salic, in the first set of feldspar, and in the second of leucite. In the ischial and arsal types the feldspar phenocrysts are large and numerous, while in the cumal, bolsenal, and fiescolal types they are small and scarce, and some olivine appears in the fiescolal type. Similarly in the viterbal, foglianal, and vesbal types the leucite phenocrysts are large, abundant, and prominent, they become small and scarce in the bagnoreal and scalal, and there are no megaphenocrysts in the orvietal and galeral types. Types which resemble each other as these do, which are found in the same row, may be said to be texturally homologous.

An analogous relationship is manifest modally. Thus the types of phlegrose show no soda-lime feldspar, those of vulsinose carry a very notable quantity of this, while in the types of monzonose this mineral becomes more prominent. In the leucitic types of ciminose soda-lime feldspar is very subordinate in amount to the alkali-feldspar, and there is no leucite in the groundmass; in those of vicose alkalifeldspar is less and soda-lime feldspar is much increased, and there is much leucite in the groundmass; while in the types of braccianose alkali-feldspar has disappeared, $i$ ts place being taken by groundmass leucite, and a labradorite or anorthite is the only feldspar. Types which resemble each other as these do, which are found in the same column, may be said to be modally homologous.

The relations are not always as simple and as clearly cut as in the above examples, complications being introduced by the presence of other minerals or differences in the minor textural characters. Thus in the above set of leucitic types there are a few feldspar phenocrysts and even less of augite present along with those of leucite, and the fabric of the groundmass, for instance, may be a trachytic one in some types and a felted, granular, or intersertal one in others. It will also frequently happen that no homologues, either modal or textural, are known. Thus the tavolatal appianose, with its very large leucite phenocrysts and abundant haüynes, does not much resemble any of the others, though it is texturally similar to the paglial pulaskose and some of the foglianal vicoses which have similarly huge leucite phenocrysts.

Furthermore, a certain degree of latitude may be allowed in the application of these homologies, as is the case with the definition of types. Thus the foglianal ciminose-auruncose and vesbal braccianose may be said to be texturally homologous with the foglianal vicose described above, though the size of the leucite phenocrysts in these two types is smaller than is true of the last in the type specimens.

\section{Correlation with the Prevailing Systems.}

It will be clear from an examination of the table on page $\mathrm{I}$, as well as from a study of the descriptions, that the distinctions between the types of the quantitative classification are more sharply drawn in some ways than is true of those of the prevailing systems. Thus rocks which would be called vulsinite in the latter are here referred to at least six distinct types, being distinguished partly by their magmatic 
positions and partly by their textural characters. The same is the case to a still greater extent with the leucite-tephrites, which are here referred to at least eleven types, while the leucite-trachytes have been split up into six types, and the leucitites into seven.

In part this is due to a recognition here of differences, either modal or textural, which have been usually disregarded either because they have been thought to be of minor importance or through a certain reluctance to add to the terminology of petrography. In part also it is due to the fact that a very considerable portion of the rocks under investigation are so extremely scarce and so rarely met with outside of the Roman Region that any recognition of differences between them has been thought to be "not worth while." In regard to this last it may be said that to be logical and consistent throughout petrography should apply its principles of classification and nomenclature impartially and irrespective of the commonness or rarity of the objects studied. This is one of the fundamental principles of the quantitative system in regard to the chemical and mineralogical constituents, ${ }^{*}$ and, it may be added, in regard to the textural characters as well.

But, however reluctant one may be to increase the "burden of new names," and therefore endeavor to force clearly distinct types into old frames, as by calling missourite a leucite-gabbro; and however neglectful petrographers may be . of the less well-known rocks, and therefore content to lump together the obviously unlike, there is a growing recognition of the need of increasingly finer distinctions, which is felt even with the rarest types as the petrographical knowledge of the remote portions of the earth increases.

This need is met, not only by the frank use of new names, but in part by ref erence of rocks belonging to the larger groups to certain "types," and in part by the use of qualifying adjectives. As illustrations of these, and as correlating the two systems, it may be pointed out that the ischial phlegrose corresponds fairly well with Rosenbusch's "Ponza typus" of the true trachytes, while the cumal phlegrose is approximately the same as his "phonolitic trachyte," though there are textural distinctions made in the quantitative system which do not obtain in the prevailing ones. Similarly, the tavolatal appianose is distinguished from the other leucite. tephrites as of the "phonolithoid type." Again, the types of galeral and hernical braccianose, that is, leucitites which carry a little labradorite, are distinguished from the romal or saccal albanose (feldspar-free leucitites) by the adjective "tephritic."

It would lead us too far astray to discuss further this important topic, but the general facts thus briefly pointed out will serve to indicate the lines along which a correlation of the types of the two systems may be studied.

* Cross, Iddings, Pirsson, and Washington, op. cit., p. 108. 


\section{PETROLOGY.}

\section{Introduction.}

Having obtained a detailed idea of the petrography of the region, it remains to discuss its petrology, the relations of the magmas and of the rock types to each other, and the conclusions which may be drawn from them. In this way we shall obtain a knowledge of the general petrological character of the region and shall be in a position to discuss the bearing of the facts on the theories of differentiation and to compare the region with others.

These regional or clan characters are of various kinds, of which the most important are the chemical, the mineralogical, and the textural, their importance being in the above order, as the chemical characters are the most, and the textural the least, dependent on the composition of the magma. With them should also be discussed the geologic occurrence of the types, the space relations or geographic distribution, the time relations or order of succession, and the quantitative relations or relative masses, of the different magmas and types, as well as the average composition or that of the parent magma, whose discussion may well be included in that of the closely connected quantitative relations.

\section{Geologic Occurrence.}

The geologic occurrence of the rocks has already been described in a previous chapter, and it only remains here to point out some of the general facts observed in the geologic structure of the volcanoes and their relations to the occurrence of the different magmas.

In the Roman Region the occurrence of the rocks is overwhelmingly that of lava flows and beds of tuff, which have been ejected at the surface from volcanic vents. No deep-seated masses have been revealed, the time for erosion since the close of volcanic activity having been too short. It is also a striking feature that dikes are extremely rare, the most abundant being in the inner walls of Monte Somma, and the only other known occurrences being a few sporadic cases in the Ciminian District observed by some geologists. It must, however, be said that my own researches failed to reveal these, and, as far as my personal knowledge goes, there is not a single dike in the region outside the Vesbian Volcano.

The main feature of interest in connection with the geologic occurrence is that the more complex volcanic structures are situated at or toward the extremities of the zone, and that they are at the same time much the most varied, in their eruptive rocks, both as to number of types and range of chemical composition, while the simpler volcanoes are toward the center of the zone and show very few types, with a narrow range in chemical composition. As far as the structures go this will be 
evident from the geological descriptions of the different districts, by which it is seen that the outer districts - the Vulsinian, Ciminian, and Sabatinian on the north, and the Campanian and Auruncan on the south-are of complex volcanic structure, and for the most part made up of the products from several vents, while of the inner ones, the Latian consists of but a single volcano, or rather the successive sommas and cones around a single vent, and the Hernican of a number of very small and simple cones. The complexity of the magmas will be discussed later.

In this connection it is interesting to note that the volcanoes of the Tuscan Region, enumerated on p. I, are all of a simple type and that their eruptive rocks are in each case extremely uniform, the different types of each being chiefly distinguished by their textural characters.* Another interesting fact in connection with these volcanoes is that dikes are quite numerous, although they are so rare at the Roman ones.

A second factor which may be significant of deeper relations is that the more complex volcanoes are very close to each other, and have been often in a state of activity contemporaneously, while the simpler central volcanoes are farther apart, both from each other and from the next outer complex ones.

As the occurrence of the rocks is so uniformly that of flows or tuffs, there is little opportunity to observe any relations between the characters of the rocks or the magmas and the geologic occurrence. So far as my knowledge goes, there is no constant or evident relation between the two. Magmas of the most diverse kinds have poured forth in both small and massive flows and have assumed the most diverse types, sometimes highly porphyritic and sometimes aphyric, sometimes leucitic and sometimes free from this mineral. The tuffs, likewise, are of very diverse petrographic characters, but as little attention was paid to them by me no generalization can be attempted here.

\section{Chemical Characters.}

The chemical characters of the Roman Region may be studied in the annexed table, where are collected the superior analyses which have been presented in the preceding pages, those heretofore unpublished except in the collection of analyses being indicated by an asterisk. Although they do not include every type found in the region, nor representatives in each district of all the types which occur in it, they are so numerous and cover such a wide range that they may be held to be representative of the whole and a satisfactory basis for generalizations.

The chemical characters of any region manifest themselves in two ways. They may be constant, or practically constant, throughout the region, and consist in the prominence or predominance of certain constituents and the comparative subordination of others. Thus some regions, like those of Christiania and Madagascar, are characterized by the abundance of alkalis relative to lime, while others, like that of eastern Canada, show lime largely preponderating over the alkalis. Or, the

* Cf. De Stefani, Boll. Soc. Geol. Ital., X, 189r, p. 550; also Washington, Jour. Geol., V, 1897, p. 349. 


\begin{tabular}{|c|c|c|c|c|c|c|c|c|c|c|c|c|c|c|c|c|c|}
\hline : & ○̊ & $\stackrel{\circ}{z}$ & $0_{0}^{n}$ & 胥 & $\sum_{2}^{0}$ & Ð & $\begin{array}{l}0 \\
\text { हू } \\
z\end{array}$ & $\begin{array}{l}0 \\
-1\end{array}$ & $\begin{array}{l}+ \\
0 \\
0\end{array}$ & $0_{-1}^{1}$ & 8 & $\overbrace{0=1}^{-1}$ & $\stackrel{\circ}{0^{n}}$ & 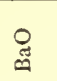 & 离 & \multicolumn{2}{|c|}{ Inclusive. } \\
\hline I & 6 I. 88 & 18.06 & 2.19 & $1.3^{8}$ & $0.6 \mathrm{I}$ & I. 5 & 6.89 & 6.72 & 0.37 & $\cdots$ & none & 0.69 & 0.07 & 0.08 & 100.52 & $\left\{\begin{array}{l}\mathrm{ZrO}_{2} \\
\mathrm{SO}_{3}\end{array}\right.$ & \\
\hline 2 & 59.79 & rg.05 & 2.95 & I. 08 & 0.36 & I. I9 & 6.79 & 7.10 & 0.24 & ... & none & $0.5^{6}$ & 0.10 & & 99.74 & & \\
\hline 3 & 60.33 & & 2.84 & I. 29 & & I. 15 & & 7.30 & . 56 & $\cdots$ & none & 0.43 & 0.04 & $\ldots$ & 100.17 & & \\
\hline 4 & 59.24 & 18.63 & 3.30 & 1.20 & 0.12 & 2.06 & 4.87 & 9.14 & 0.86 & .... & none & $0.5^{6}$ & 0.15 & 0.06 & 100.54 & $\left\{\begin{array}{l}\mathrm{SO}_{3} \\
\mathrm{Cl}^{3}\end{array}\right.$ & $\left.\begin{array}{l}0.17 \\
0.08\end{array}\right\}$ \\
\hline $\begin{array}{l}5 \\
6\end{array}$ & 61.62 & I8. II & 2.36 & I. 28 & $\begin{array}{l}0.56 \\
1.05\end{array}$ & I. 44 & 5.77 & $\begin{array}{r}7.60 \\
8.86\end{array}$ & 0.78 & & none & 0.87 & 0.13 & $\cdots$ & 100.67 & $\mathrm{Cl}$ & 0.15 \\
\hline 6 & & & $\begin{array}{l}.55 \\
.22\end{array}$ &.$\infty 2$ & & & & $\begin{array}{l}8.86 \\
8.68\end{array}$ & $\begin{array}{l}0.54 \\
0.50\end{array}$ & $\begin{array}{l}0.11 \\
0.44\end{array}$ & ane & & & $\cdots$ & & $\dot{c} i^{\circ}$ & 0.17 \\
\hline & 5 & & & & & & & & .50 & 0.44 & $\cdots$ & & 1 & $\cdots$ & 0.49 & & 0.17 \\
\hline 8 & 57.50 & 18.80 & 4.37 & 0.62 & I. 20 & 3.84 & 3.16 & 8.39 & $0.6 \mathrm{I}$ & $0.3^{8}$ & .... & 0.50 & 0.28 & .... & 100.21 & $\left\{\begin{array}{l}\mathrm{MnO} \\
\text { t }\end{array}\right.$ & $\left.\begin{array}{l}0.03 \\
0.57\end{array}\right\}$ \\
\hline $9^{*}$ & 56.19 & 20.75 & I. 71 & 2. 19 & $x .14$ & $3 \cdot 53$ & 2.86 & 10.47 & 0.70 & 0.30 & none & 0.65 & 0.24 & $\cdots$ & 100.73 & . & ... \\
\hline & 55.17 & 19.60 & 3.27 & 2.74 & I. $5^{8}$ & 3.73 & .27 & $9 \cdot 5^{8}$ & .99 & & none & 0.69 & 0.20 & & 99.82 & & \\
\hline & 57.60 & 19.43 & 2.49 & I. 92 & 1.06 & 4.17 & .55 & 8.71 & 0.32 & $0.3^{2}$ & .... & $0.4^{6}$ & 0.20 & .... & $\begin{array}{r}9.02 \\
100.50\end{array}$ & $\begin{array}{l}\mathrm{MnO} \\
\mathrm{ZrO}\end{array}$ & $\begin{array}{l}0.23 \\
0.04\end{array}$ \\
\hline & 55.07 & 20.83 & 2.12 & I.99 & $1 . \infty$ & 3.37 & $4 . \infty$ & 8.65 & 0.77 & 0.59 & none & 0.82 & 0.19 & 0.20 & 99.73 & $\left\{\begin{array}{l}\mathrm{SO}_{3} \\
\mathrm{Ce} \mathrm{C}_{3} \\
\mathrm{SrO}\end{array}\right.$ & $\left.\begin{array}{c}\text { trace } \\
0.03 \\
0.06\end{array}\right\}$ \\
\hline & 55.87 & 20.85 & 2.34 & I. 10 & 0.48 & 3.07 & $4.8 \mathrm{I}$ & I0.49 & 0.34 & $\ldots$ & none & 0.79 & $0 . I I$ & 0.09 & 100.55 & 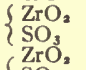 & $\left.\begin{array}{l}0.07 \\
0.14 \\
0.02\end{array}\right\}$ \\
\hline & 50.25 & $2 \mathrm{I} .4 \mathrm{I}$ & I. 76 & I. 82 & 0.31 & $4 \cdot 4^{8}$ & 5.16 & II. 32 & 0.62 & 0.34 & 0.32 & 0.57 & 0.12 & 0.13 & 99.86 & $\left\{\begin{array}{l}\mathrm{SO}_{3} \\
\mathrm{Cl} \\
\mathrm{SrO}\end{array}\right.$ & $\left.\begin{array}{l}1.05 \\
0.18 \\
\text { trace }\end{array}\right\}$ \\
\hline $5^{*}$ & $59.4 \mathrm{I}$ & 9.06 & $\begin{array}{l}.87 \\
21\end{array}$ & .42 & .05 & 4.09 & $2.5^{8}$ & $5 \cdot 29$ & 0.64 & $0.9 \mathrm{I}$ & none & $1 . \infty$ & b. 29 & & $1 \infty 0.6 \mathrm{I}$ & & \\
\hline & & & $\begin{array}{l}2.21 \\
\text { I. } 34\end{array}$ & & & 6.69 & & & & … & & $.6 \mathrm{r}$ & .17 & 0.12 & 100.21 & $\mathrm{SO}_{3}$ & trace \\
\hline & 1.40 & & & & .90 & 0.09 & & & 0.23 & D. 15 & none & 0.53 & $0.3^{6}$ & ... & $1 \infty 0.21$ & ...... & …... \\
\hline & $57 \cdot 3 \mathrm{I}$ & I4.4I & I. $2 \mathrm{I}$ & 4.37 & 7.80 & 6.90 & I. 35 & $6.3^{8}$ & 0.18 & ... & none & 0.40 & 0.30 & none & $1 \infty 0.6 \mathrm{r}$ & & \\
\hline & 55.85 & 18. 34 & 3.77 & x. 88 & 1.73 & 3.84 & 3.39 & 8.77 & I. I 4 & $\cdots$ & none & 0.59 & $0.3^{8}$ & 0.17 & 99.90 & & $\left.\begin{array}{l}\text { none } \\
0.05\end{array}\right\}$ \\
\hline & 55.21 & 18.78 & 2.69 & 2.86 & х. 68 & $4.6 \mathrm{I}$ & 3.13 & 8.45 & 0.99 & $\cdots$ & none & 0.71 & 0.22 & 0.18 & $99.6 \mathrm{I}$ & $\left\{\begin{array}{l}\mathrm{Zr} \\
\mathrm{SO} \\
\mathrm{S}\end{array}\right.$ & $\left.\begin{array}{c}0.10 \\
\text { one } \\
\text { one }\end{array}\right\}$ \\
\hline & 52.14 & I $5.9 \mathrm{I}$ & 2.15 & 5.19 & 5. II & 8.55 & $x .92$ & 7.24 & 0.10 & 0.09 & none & I. 22 & 0.24 & 0.20 & 100.13 & $\left\{\begin{array}{l}\mathrm{ZrO}_{2} \\
\mathrm{SO}_{3} \\
\mathrm{ZrO}_{2}\end{array}\right.$ & $\left.\begin{array}{l}c e \\
07 \\
10\end{array}\right\}$ \\
\hline & 55.22 & 18.43 & 2.02 & 3.10 & 2.75 & 5.70 & $3.5^{\circ}$ & $7 \cdot 5^{8}$ & 0.46 & 0.29 & none & 0.87 & $0.2 \mathrm{I}$ & 0.07 & $1 \infty 0.4 \mathrm{I}$ & $\left\{\begin{array}{l}\mathrm{SO}_{3} \\
\mathrm{Cr}_{3} \mathrm{O}_{3}\end{array}\right.$ & $\left.\begin{array}{c}0.11 \\
\text { none }\end{array}\right\}$ \\
\hline & 56.75 & 18.03 & $\begin{array}{l}2.22 \\
2.45\end{array}$ & 3.04 & 2.02 & 4.68 & 4.85 & 5.92 & o. 18 & $\cdots$ & none & 1.24 & 2,34 & & $99 \cdot 3^{8}$ & & 0.11 \\
\hline & $54 \cdot 7^{2}$ & .60 & 2.45 & .09 & .90 &.$\infty$ & $.5^{2}$ & 6.87 & .08 & $\cdots$ & $\cdots$ & 0.65 & race & $\cdots$ & 99.93 & $\begin{array}{l}\mathrm{Cl} \\
\mathrm{ZrO}\end{array}$ & $\begin{array}{l}05 \\
07\}\end{array}$ \\
\hline & 52.37 & 20.89 & I. $2 \mathrm{I}$ & $4 \cdot 44$ & I. 74 & 5.08 & 2.90 & 7.47 & I. 46 & $0.5 \mathrm{I}$ & none & I.I 5 & $0.5 I$ & 0.16 & 99.96 & $\left\{\begin{array}{l}\mathrm{SO}_{3} \\
\mathrm{Cl}\end{array}\right.$ & $\left.\begin{array}{l}\text { none } \\
\text { none }\end{array}\right\}$ \\
\hline & 50.86 & 18.48 & 4.03 & 3.45 & 2.55 & 7.77 & 2.23 & 7.15 & I. $5 \mathrm{I}$ & 0.16 & none & $1 . \infty$ & 0.46 & 0.17 & 99.84 & & $\begin{array}{l}02 \\
\text { ne }\end{array}$ \\
\hline & 5 I. 2 I & I 8.28 & 3.07 & 4.19 & 3.47 & 7.86 & 2.49 & 6.60 & 0.56 & o.16 & none & I. 43 & 0.35 & 0.10 & 99.77 & $\left\{\begin{array}{l}\mathrm{ZrO}_{2} \\
\mathrm{SO}_{3}\end{array}\right.$ & $\left.\begin{array}{l}\text { none } \\
\text { none }\end{array}\right\}$ \\
\hline & 55.69 & 17.87 & 4.07 & 3.26 & $3.4 \mathrm{I}$ & 6.87 & 2.89 & $4 \cdot 4 \mathrm{I}$ & 0.17 & $\ldots$. & none & 1.02 & 0.19 & ... & 99.85 & $\cdots$ & $\cdots$ \\
\hline & 54.83 & 19.59 & 1. 66 & 3.04 & I. 49 & 4.05 & 2.92 & 10.40 & 0.77 & 0.49 & none & 0.73 & 0.17 & 0.15 & 100.30 & $\left\{\begin{array}{l}\mathrm{ZrO}_{2} \\
\mathrm{SO}_{3}\end{array}\right.$ & \\
\hline & 51.20 & $2 \mathrm{I} .2 \mathrm{I}$ & $2.3^{8}$ & 3.67 & I. 99 & $5 \cdot 4^{2}$ & $2.1 \mathrm{I}$ & 10.63 & 0.28 & 0.10 & none & 0.74 & 0.36 & 0.33 & 100.45 & $\left\{\begin{array}{l}\mathrm{ZrO}_{2} \\
\mathrm{SO}_{3} \\
\mathrm{ZrO}_{2}\end{array}\right.$ & \\
\hline & 50.68 & $\times 9.46$ & 3.96 & $2.5^{I}$ & 2.24 & 6.78 & $2.6 \mathrm{I}$ & $9.3^{8}$ & 0.46 & 0.16 & none & 0.89 & 0.33 & 0.15 & $99.6 \mathrm{I}$ & $\left\{\begin{array}{l}\mathrm{SO}_{3} \\
\mathrm{CuO}\end{array}\right.$ & $\left.\begin{array}{l}\text { none } \\
\text { none }\end{array}\right\}$ \\
\hline & 50.36 & 17.62 & 4.80 & 2.53 & 3.27 & $7.6 \mathrm{I}$ & I. 99 & 9.39 & 1.19 & $\cdots$ & none & 1.09 & 0.40 & ... & 100.25 & & \\
\hline & 50.24 & 18.43 & 2.54 & 5.65 & 3.65 & 7.83 & 2.45 & 7.45 & 0.36 & $\ldots$ & none & 1. 19 & 0.47 & 0.29 & $1 \infty 0.55$ & & \\
\hline & 47.65 & 18.13 & 2.63 & 6.48 & 4.19 & 9.01 & 2.78 & 7.47 & 0.13 & $0.1 \mathrm{I}$ & none & I. I3 & 0.50 & 0.24 & 100.47 & & $\begin{array}{l}0.02 \\
\text { trace }\end{array}$ \\
\hline & 47.89 & 17.87 & 4.93 & 3.64 & 3.68 & 8.70 & 2.60 & 8.23 & 0.65 & 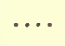 & none & 0.77 & 0.36 & 0.28 & 99.68 & & $\begin{array}{l}02 \\
06\end{array}$ \\
\hline & 47.20 & 1 7.66 & $3.5 \mathrm{I}$ & 4.50 & 4.20 & 9.52 & .25 & 7.63 & 0.72 & 0.57 & none & I.19 & $0.5^{8}$ & 0.19 & $99 \cdot 76$ & $\left\{\begin{array}{l}\mathrm{Zr} \\
\mathrm{SC}\end{array}\right.$ & \\
\hline & 48. Iо & 17. 56 & $2.4^{8}$ & 6.10 & 4.27 & 8.16 & 2.67 & 7.90 & 0.12 & 0.04 & none & I. $4 \mathrm{I}$ & I.OI & 0.08 & 99.90 & $\left\{\begin{array}{l}\mathrm{SO}_{3} \\
\mathrm{CuO}\end{array}\right.$ & $\begin{array}{l}\text { trace } \\
\text { none }\end{array}$ \\
\hline & 47.71 & $17.6 \mathrm{I}$ & 2.46 & 5.68 & 4.80 & $9.4^{2}$ & 2.75 & 7.64 & trace & .... & none & 0.37 & 0.77 & 0.26 & 99.53 & $\left\{\begin{array}{l}\mathrm{ZrO}_{2} \\
\mathrm{SO}_{3} \\
\mathrm{ZrO}_{2}\end{array}\right.$ & \\
\hline & $47 \cdot 39$ & I 4.79 & 3.10 & 5.08 & 6.77 & $11.6 \mathrm{r}$ & x. 49 & 6.03 & 0.77 & 0.28 & none & I. $4 x$ & 0.45 & 0.15 & 100.35 & $\left\{\begin{array}{l}\mathrm{SO}_{3} \\
\mathrm{Ce} \mathrm{O}_{3} \\
\mathrm{SrO}\end{array}\right.$ & $\left.\begin{array}{l}\text { none } \\
0.05 \\
0.04\end{array}\right\}$ \\
\hline & 44.89 & 12.73 & $3.3 \mathrm{I}$ & $4 \cdot 35$ & 13.71 & 2.95 & 1.02 & 3.66 & 1.59 & 0.27 & none & 0.95 & 0.23 & 0.08 & 99.77 & & \\
\hline & 46.24 & 14.42 & 4.06 & $4 \cdot 36$ & 6.99 & 13.24 & x. 65 & 6.37 & 0.78 & 0.57 & none & I.17 & $0.4 \mathrm{I}$ & 0.13 & 100.41 & $\left\{\begin{array}{l}\mathrm{ZrO}_{2} \\
\mathrm{SO}_{3} \\
\mathrm{ZrO}_{2}\end{array}\right.$ & \\
\hline & 46.27 & I 7.25 & 3.94 & 3.23 & 5.08 & II 40 & 2.67 & $8.5^{8}$ & 0.37 & 0.13 & none & I.II & 0.39 & 0.10 & $100.6 \mathrm{I}$ & $\begin{array}{l}\mathrm{SO}_{3} \\
\mathrm{SrO}^{2} \\
\mathrm{ZrO}_{3}\end{array}$ & $\left.\begin{array}{l}\text { trace } \\
0.06 \\
0.02\end{array}\right\}$ \\
\hline & 47.05 & 17.08 & 3.04 & 4.89 & 5.67 & 10.63 & I. 6I & $7 \cdot 52$ & $0.7 \pi$ & 0.22 & none & I. I5 & 0.17 & 0.09 & 99.90 & $\left\{\begin{array}{l}\mathrm{SO}_{3} \\
\mathrm{CuO}\end{array}\right.$ & $\left.\begin{array}{l}\text { none } \\
\text { none }\end{array}\right\}$ \\
\hline & 45.99 & x6.56 & 4.17 & $5 \cdot 38$ & $5 \cdot 30$ & 10.47 & 2. 18 & 8.97 & 0.45 & $\ldots$ & none & 0.37 & 0.56 & 0.25 & 100.65 & $\mathrm{SrO}$ & $\begin{array}{l}0.05 \\
\text { none }\end{array}$ \\
\hline
\end{tabular}




\begin{tabular}{|c|c|c|c|c|c|}
\hline そุ & District. & Locality. & Old name. & New name. & Subrang. \\
\hline $\mathbf{I}$ & Campanian..... & Marecocco, Ischia............. & Augite-trachyte, Ischia type.... & Ischial nordmarkose-phlegrose.. & I. $5 \cdot 1 \cdot 3-4$. \\
\hline 2 & Campanian..... & Monte di Cuma, Phlegrean Fields & Phonolitic trachyte, Cuma type. & Cumal nordmarkose-phlegrose.. & I. $5 \cdot 1 \cdot 3-4$. \\
\hline 3 & Campani & Monte Nuovo, Phlegrean Fields & Phonolitic trachyte, Cuma type. & Cumal nordmarkose-phlegrose.. & I. $5 \cdot 1 \cdot 3-4$ \\
\hline 4 & Ciminian....... & Block in tuff, Vico Volcano.... & Phonolitic trachyte, Cuma type. & Cumal phlegrose..... & I. $5 \cdot 1 \cdot 3 \cdot$ \\
\hline 5 & Campanian...... & $\begin{array}{l}\text { Monte Rotaro, Ischia .......... } \\
\text { Below castle, Bolsena............ }\end{array}$ & $\begin{array}{l}\text { Trachyte-obsidian, Rotaro type. } \\
\text { Vulsinite, Bolsena type }\end{array}$ & $\begin{array}{l}\text { Rotaral phlegrose............ } \\
\text { Bolsenal vulsinose. }\end{array}$ & I. $5 \cdot 1 \cdot 3$ \\
\hline $\begin{array}{l}6 \\
7\end{array}$ & Campanian........ & $\begin{array}{l}\text { Caprara,Astroni Volcano, Phie- } \\
\text { grean Fields. }\end{array}$ & $\begin{array}{l}\text { Vulsinite, Bolsena type ......... } \\
\text { Vulsinite, Bolsena type ....... }\end{array}$ & $\begin{array}{l}\text { Bolsenal vulsinose.............. } \\
\text { Bolsenal vulsinose............. }\end{array}$ & $\begin{array}{l}\text { I. } 5 \cdot 2 \cdot 2 \cdot \\
\text { I. } 5 \cdot 2 \cdot 2 .\end{array}$ \\
\hline 8 & Campanian. . & $\begin{array}{l}\text { Pagliaroni, Astroni Volcano, } \\
\text { Phlegrean Fields. }\end{array}$ & Vulsinite, Bolsena type ... & Bolsenal vulsinose.... & I. $5 \cdot 2 \cdot 2$. \\
\hline $9^{*}$ & Ciminian... & $\begin{array}{l}\text { Sorgente di Grignano, Vico } \\
\text { Volcano. }\end{array}$ & Leucite-trachyte, Viterbo type... & Viterbal vulsinose. . . . . . . . . & I. $5 \cdot 2 \cdot 2$. \\
\hline Io & $\begin{array}{l}\text { Ciminian......... } \\
\text { Ciminian....... }\end{array}$ & $\begin{array}{l}\text { Below San Rocco, Vico Volcano. } \\
\text { Rotondella, Astroni Volcano, } \\
\text { Phlegrean Fields. }\end{array}$ & $\begin{array}{l}\text { Leucite-trachyte, Viterbo type... } \\
\text { Vulsinite, Bolsena type........ }\end{array}$ & $\begin{array}{l}\text { Viterbal vulsinose.............. } \\
\text { Bolsenal vulsinose-pulaskose... }\end{array}$ & $\begin{array}{l}\text { I. } 5 \cdot 2 \cdot 2 . \\
\text { I. } 5 \cdot 2 \cdot 2-3 .\end{array}$ \\
\hline $12 *$ & Vulsinian ....... & Proceno, near Acquapendente.. & Leucite-trachyte, Paglia type ... & Paglial procenose-pulaskose.... & I.6-5.2.3. \\
\hline 13 & Sabatinian...... & $\begin{array}{l}\text { Poggio Muratella, Lake Brac- } \\
\text { ciano. }\end{array}$ & Ieucite-phonolite, Sabatino type. & Sabatinal beemerose... & I. 6.1 .3 . \\
\hline $14 *$ & Latian. . & $\begin{array}{l}\text { Osteria Tavolato, Via Appia } \\
\text { Nuova. }\end{array}$ & Leucite-tephrite, Tavolato type. & Tavolatal janeirose-appianose... & II-I. $7 \cdot 1 \cdot 3 \cdot$ \\
\hline $25^{*}$ & Ciminian... & La Cava, Cimino Volcano....... & Biotite-latite, Soriano type...... & Sorianal harzose. . & \\
\hline 16 & $\cdots$ & $\begin{array}{l}\text { Near Vetralla, Vico Volcano.... } \\
\text { Fontano Fiescoli, Cimino Vol- }\end{array}$ & $\begin{array}{l}\text { Vulsinite, Arso type............ } \\
\text { Ciminite, Fiescoli type }\end{array}$ & Arsal vulsinose-cimi & I-II. $5 \cdot 2.2$. \\
\hline I7 & Ciminia & cano. & Ciminite, Fiescoll type......... & Fiescolal ciminose....... & II. $5 \cdot 2 \cdot 2$. \\
\hline I8 & Ciminian... & La Colonetta, Cimino Volcano.. & Ciminite, Fiescoli type........ & Fiescolal ciminose..$\ldots \ldots \ldots \ldots$ & II. $5 \cdot 2 \cdot 2$. \\
\hline I9 & V'ulsinian....... & Bagnorea, near Orvieto........ & Leucite-trachyte, Bagnorea type. & Bagnoreal ciminose .......... & II. 5.2 .2 . \\
\hline 20 & Ciminian....... & Monte Venere, Vico Volcano... & Leucite-trachyte, Bagnorea type. & Bagnoreal ciminose...$\ldots \ldots \ldots$ & II. $5 \cdot 2 \cdot 2$. \\
\hline $2 I *$ & Ciminian....... & San Martino, Vico Volcano..... & $\begin{array}{l}\text { Leucite-tephrite, San Martino } \\
\text { type. }\end{array}$ & Martinal vicose-ciminose... & II.6-5.2.2. \\
\hline $22 *$ & Ciminian....... & Poggio Cavaliere, Vico Volcano. & Vulsinite, Arso type .......... & Arsal monzonose............. & II. $5 \cdot 2 \cdot 3$. \\
\hline 23 & Campanian..... & 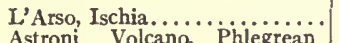 & Vulsinite, Arso ty pe.......... & Arsal monzonose ............ & II. $5 \cdot 2 \cdot 3 \cdot$ \\
\hline 24 & Campani & $\begin{array}{l}\text { Astroni } \\
\text { Fields. }\end{array}$ & 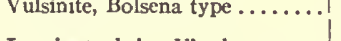 & & \\
\hline $25^{*}$ & Ciminian....... & $\begin{array}{l}\text { Croce di San Martino, Vico } \\
\text { Volcano. }\end{array}$ & Leucite-tephrite, Viterbo type .. & Foglianal ciminose-auruncose. & II. $5 \cdot 2-3 \cdot 2$. \\
\hline $26 *$ & Auruncan....... & Below Orchi.............. & Leucite-trachyte, Teano type... & Teanal ciminose-auruncose..... & $\cdot 5 \cdot 2-3 \cdot 2$ \\
\hline $27^{*}$ & Vulsinian....... & Toscanella................. & Leucite-tephrite, Orvieto type... & Orvietal auruncose........... & II. $5 \cdot 3 \cdot 2$. \\
\hline 28 & Auruncan ....... & $\begin{array}{l}\text { Monte Santa Croce, Rocca } \\
\text { Monfina. }\end{array}$ & Biotite-latite, Monfina type..... & Monfinal shoshonose......... & II. $5 \cdot 3 \cdot 3$ \\
\hline $29^{*}$ & Ciminian.... & Monte Fogliano, Vico Volcano.. & Leucite-tephrite, Viterbo type... & Foglianal vicose $\ldots \ldots \ldots \ldots \ldots$ & II. 6.2.2. \\
\hline $30^{*}$ & Auruncan $\ldots . .$. . & Monte San Antonio........... & Leucite-tephrite, Viterbo type... & Foglianal vicose...... & II. 6.2.2. \\
\hline $31 *$ & Sabatinian...... & Poggio Cotognola, Bracciano... & Leucite-tephrite, Bagnorea type. & Bagnoreal vicose............. & II. 6. 2. 2 . \\
\hline $32 *$ & Sabatinian...... & Madonna del Riposo, Bracciano. & Leucite-tephrite, Bagnorea type. & Bagnoreal vicose............. & II. 6.2.2. \\
\hline 33 & Vulsinian....... & Monte Cavallo, near Orvieto... & Leucite-tephrite, Orvieto type.. & Orvietal vicose $\ldots \ldots \ldots \ldots \ldots \ldots$ & II. 6.2. 2 . \\
\hline $34^{*}$ & Campanian..... & $\begin{array}{l}\text { Lava of } I_{72} \text {, below Observa- } \\
\text { tory, Mount Vesuvius. }\end{array}$ & Leucite-tephrite, Vesuvius type. & Vesbal braccianose.......... & II. $7 \cdot 2.2$. \\
\hline 35 & Sabatinian...... & Crocicchie, S. of Lake Bracciano. & Leucitite, Galera type......... & Galeral braccianose........... & II. $7 \cdot 2 \cdot 2$. \\
\hline $36 *$ & Latian.......... & Arcioni, Rocca di Papa........ & Leucitite, Hernici type......... & Hernical braccianose ..... & II. $7 \cdot 2 \cdot 2$. \\
\hline $37^{*}$ & Campanian..... & $\begin{array}{l}\text { Lava of rgo3, Valle del Inferno, } \\
\text { Mount Vesuvius. }\end{array}$ & Leucite-tephrite, Atrio type..... & Atrial braccianose............ & II. $7 \cdot 2.2$. \\
\hline $38 *$ & Campanian..... & $\begin{array}{l}\text { Lava of I63I, La Scala, Mount } \\
\text { Vesuvius. }\end{array}$ & Leucite-tephrite, Scala type..... & Scalal vesuvose-braccianose .... & II. 8-7.2. 2 . \\
\hline $39 *$ & Vulsinian....... & Monte Jugo, near Montefiascone. & Leucitite, Galera type ........ & Galeral albanose-jugose........ & III. $8-7 \cdot 2.2$. \\
\hline $40 *$ & Vulsinian....... & Fiordine, near Montefiascone... & Leucite-basanite, Fiordine type. & Fiordinal fiasconose.......... & III. $7 \cdot 3 \cdot 2$. \\
\hline $41 *$ & Vulsinian........ & Monte Rado, E. of Lake Bolsena. & Leucitite, Rome type.......... & Romal albanose.. ........... & III. 8. 2.2. \\
\hline $42^{*}$ & Hernican........ & Ticchiena, near Frosinone...... & Leucitite, Sacco type ........ & Saccal albanose...$\ldots \ldots \ldots$ & III. 8.2.2. \\
\hline $43^{*}$ & Hernican....... & Pofi....................... & Leucitite, Sacco type ....... & Saccal albanose............. & III. 8.2.2. \\
\hline 44 & Latian ........ & Capo di Bove, Via Appia....... & $\begin{array}{l}\text { Leucitite, Capo di Bove type, } \\
\text { "cecilite." }\end{array}$ & Boval albanose...$\ldots \ldots \ldots \ldots$ & III. 8. 2. 2. \\
\hline
\end{tabular}


rocks of a region may have the common feature of high magnesia, or be uniformly quaric (siliceous) and with lenads (leucite and nephelite) quite absent, and so on. These may be called the absolute characters, in contradistinction to the serial ones to be mentioned presently. Superposed on these absolute characters, if one may so express oneself, are the characters which may be called serial, and which consist in a definite variation in the amounts of one or more constituents concomitant with a variation in one or more others, which variations may be either in the same or opposite direction. Thus it is now well established for many regions, and as a general (though not invariable) character of igneous rocks, that the alkalis and alumina increase with increasing silica, while iron, magnesia, and often lime decrease. Or again, the relations between potash and soda, or between magnesia and ferrous oxide, may vary with variations in the silica.

Assuming the derivation of the rocks of any given region from a common magma by differentiation, it would seem that the absolute characters are dependent on the composition of this, while the serial characters are due to the chemical changes brought about by the processes of differentiation, the absolute characters persisting in spite of these. For these reasons it would be advisable to keep clear the distinction between the two as far as possible.

\section{Absolute Chemical Characters.}

The range of silica is considerable, from 62 to 45 per cent, while if the relative masses of the various rock types are taken into consideration, the range in the most abundant types would be only from 56 to 47 . In general terms, therefore, the silica may be said to be medium to rather low and with a rather narrow range. Alumina is generally high and its most marked characteristic is its very narrow range in most of the analyses, only from $I 7$ to 20 per cent. In only five is it higher, and then but slightly so, from 20.8 to $2 \mathrm{r} .4$, while in five others it is lower, from r 6.6 to $\mathrm{r} 2.7$, these ten being mostly of rather rare types.

The oxides of iron and magnesia are almost uniformly low, and the range comparatively small, with a few exceptions, though not as narrow as that of alumina. Lime, in contradistinction to the other bivalent oxides, is almost uniformly quite high, and with a very considerable range. Soda, on the other hand, is rather low, and while the total range is considerable (from I.O to 7.2), it is only from $I .5$ to 3.5 in the majority of the analyses. Potash, like lime, is distinctly high, and with a very considerable range, from 3.7 to I .3 , the higher figures being almost the highest ever recorded for this constituent in igneous rocks, although the range of the majority is only from 6.4 to 9.6 per cent.

Turning to the minor constituents, we find sufficient data for many of them to permit of some general statements. Titanium dioxide is almost uniformly high, ranging from 0.3 to $\mathrm{I} .4$, and in most of the rocks falling between 0.6 and $\mathrm{I} .2$ per cent. As this constituent was determined in most cases by the very reliable colorimetric method, the figures for it may be regarded as more trustworthy than is 
usually true of European rocks. Zirconia, on the other hand, is always low, never rising above 0 . I per cent and sometimes being either absent or present in unweighable traces. The content of phosphorus is also low, the percentages of phosphoric pentoxide running from 0 .I to $I .0$, though figures higher than 0.5 are exceptional. Sulphur trioxide and chlorine are seldom met with in more than traces, and are frequently absent, though about I per cent of $\mathrm{SO}_{3}$ is shown in one very rare type. Carbon dioxide seems to be uniformly absent, a somewhat remarkable fact in view of the generally high content in lime, and even though fresh and unaltered rocks were chosen for analysis.

The oxides of the rare-earth metals, when looked for, were found in very small amount both in salic and femic types, and it is possible that traces of them are uniformly present in most of the rocks. Chromium was only observed once, in a rock rich in olivine, and even here in scarcely more than a trace, and was apparently absent in all the others. Nickel seems to be absent, except as possible traces in the more femic rocks, and the absence of copper in all cases where tests were made for it is noteworthy, as it is often supposed that this element is quite frequent in Italian igneous rocks,* on the basis of analyses by Speciale $\dagger$ of lavas from the Hernican District and by Förstner+ of lavas from Pantelleria. The presence of copper in the last will be investigated shortly on material recently collected by the writer.

Although for reasons explained elsewhere manganese was not estimated in any of the rocks, the color of the sodium carbonate fusion showed that it is always present. But it probably seldom rises above 0.25 nor falls below 0.05 per cent, and an average of about 0 . Io per cent would be very close to the truth. Of the other elements the occurrence of baryta in, for this constituent, quite large amounts, is very noteworthy. It was found in practically every case where it was looked for in amounts varying from 0.06 to 0.29 per cent. Strontia was, unfortunately, only occasionally estimated and was always found to be in scarcely more than traces when present, and occasionally absent.

Connected with these absolute characters, or rather as an extension or more detailed statement of some of them, are certain relations between some of the constituents which persist more or less uniformly throughout the whole series. The first which may be mentioned is the general deficiency of the magmas in silica. In only two or three cases is there an excess of silica over the bases, that is, more than sufficient to form the most highly silicated minerals. In the great majority of the rocks, even in those which are perfelic, there is so little of this that the less highly silicated minerals, as leucite, nephelite, olivine, or melilite, are formed, either in the norm or in the mode, and usually in both.

A second important relation is the dominance of potash over soda (molecularly), which is very marked, and which is shown in the systematic classification by

* Cf. J. H. L. Vogt, Zeits. prakt. Geol., 1898, p. 317.

† S. Speciale, Boll. Com. Geol. Ital., I879, p. 302.

¥ H. Förstner, Zeits. Kryst., VIII, I883, pp. 173, 179, 182 . 
the abundance of dopotassic subrangs. The exceptions to this are for the most part confined to the rarer rock types, the only important one being the rather common types of phlegrose (I.5.I.3), which will be discussed later.

Another of scarcely less importance is the dominance of alkalis over salic lime, that is lime which enters into the normative feldspars. This is clearly shown by the abundance of rocks falling in peralkalic or domalkalic rangs, the alkalicalcic rangs being few and mostly represented by rare types.

As a general thing, also, the molecules of ferrous oxide and magnesia together surpass those of total lime, and they invariably do those of femic lime, while molecularly magnesia is usually higher than ferrous oxide, though there are some notable exceptions to this last statement. Similarly titanium is invariably higher than phosphorus and baryta higher than strontia, these being the almost universal relations.

To sum up the absolute chemical characters of the region then, we may say that as regards the main constituents, silica is moderately high to moderately low and mostly deficient; alumina uniformly high and with a remarkably narrow range; ferric and ferrous oxides and magnesia low and lime rather high; magnesia usually dominating ferrous iron, and both usually dominating lime and always femic lime; the total alkalis high, with soda usually low to moderately high, and potash high to very high; potash dominating soda and the alkalis together dominating salic lime; as regards the minor constituents, titanium and barium are high and phosphorus and manganese low, these being always present; zirconia, strontia, and the oxides of cerium, etc., are usually present, but only in traces; sulphur and chlorine in varying but small amounts; and chromium, nickel, and copper are absent.

\section{Serial Chemical Characters.}

The most obvious of these is that as silica falls the iron oxides, magnesia, lime, titanium, and phosphorus rise, while the total alkalis fall, alumina keeping fairly constant. Except as regards alumina this is the usual relation, obtaining not only for comagmatic regions (petrographic provinces), but for igneous rocks as a whole. It finds its expression in the division of classes in the quantitative system based on the relative amounts of salic and femic minerals in the norm.

Within this general variation some more special ones of interest may be observed. As silica decreases, or as the femic components increase, the amount of, potash relative to soda increases on the whole. There are some exceptions to this, but the general law for this region seems to be amply substantiated by the great majority of the analyses. It is, however, of great importance to note that, with the exception of the persalic rocks in which soda is high, this relative increase in potash is brought about rather by increase in the potash relatively to the silica and the femic constituents than by decrease in the soda, the amount of this varying only within rather narrow limits. It is also shown by the general fact that the potash is higher relatively to the soda as the amount of lenic minerals in the norm or of 
leucite in the mode rises, the persalic rocks being very largely or wholly feldspathic, while the salfemanes are almost entirely leucitic and non-feldspathic. In the systematic quantitative classification this is well brought out by the fact that the majority of the occurrences of sodipotassic subrangs fall in the persalane class, as phlegrose (I. 5. I. 3), which is quite common, pulaskose (I. 5. 2. 3), procenose (I. 6. 2. 3), beemerose (I. 6. I. 3), and appianose (I. 7. I. 3); while in the dosalane class the only sodipotassic subrangs are harzose (II. 4. 3), monzonose (II. 5. 2. 3), and shoshonose (II. 5. 3. 3), which are decidedly sporadic, and that, finally, no sodipotassic subrangs of the salfemane class are known.

While the alkalis dominate salic lime as a rule, they do so to a much greater extent as the salic components increase, as is shown in the classification by the frequent occurrence of peralkalic rangs in the rocks of the persalane class, alkalicalcic rangs being observed only in the dosalane class, though they do not occur in the more lenic orders of dosalane nor in the salfemanes, the relative increase in alkalis, especially potash, and the decrease in alumina here coming into play.

It has been said above that magnesia dominates ferrous oxide in the majority of cases, and while this is true it is especially so of the more femic rocks, notably the salfemanes, where the ratio of $\mathrm{MgO}$ to $\mathrm{FeO}$ is apt to be high. This decreases in the dosalanes, and in the persalanes is often about unity, magnesia thus increasing relatively to ferrous oxide as the femic components increase or as silica decreases. A similar relation holds good of the predominance of magnesia and ferrous oxide over femic lime; this ratio increasing on the whole with increase in the femic minerals and lenads.

As regards the minor constituents, both titanium and phosphorus increase on the whole toward the femic end, though there are some exceptions. Zirconia seems to be most apt to be present in the more salic rocks, especially when these are sodipotassic, and the prevalence of this constituent in sodic magmas is well known. Barium shows less regular relations, but it may be said that in general it is somewhat more abundant in the more femic magmas and especially in those which have potash high relatively to soda. Concerning strontium the data are unfortunately rather few, and while there seems to be no very general rule in regard to it, there are indications that it is more apt to be present in considerable amount in the more femic magmas and especially in those rich in lime. But the figures reported for it are uniformly so small that they are not conclusive. Chlorine and sulphuric anhydride are most common in the sodipotassic magmas, especially when persalic.

\section{Normative Characters.}

In the annexed table are given the norms of the various rocks, calculated from the analyses in the preceding table, and arranged in the same order. A study of these norms will give further insight into the chemical relations of the rocks and their magmas, especially their relations to the quantitative system, and will serve as an introduction to the discussion of their modes or the minerals actually present in them. 
Norms of Roman Rocks.

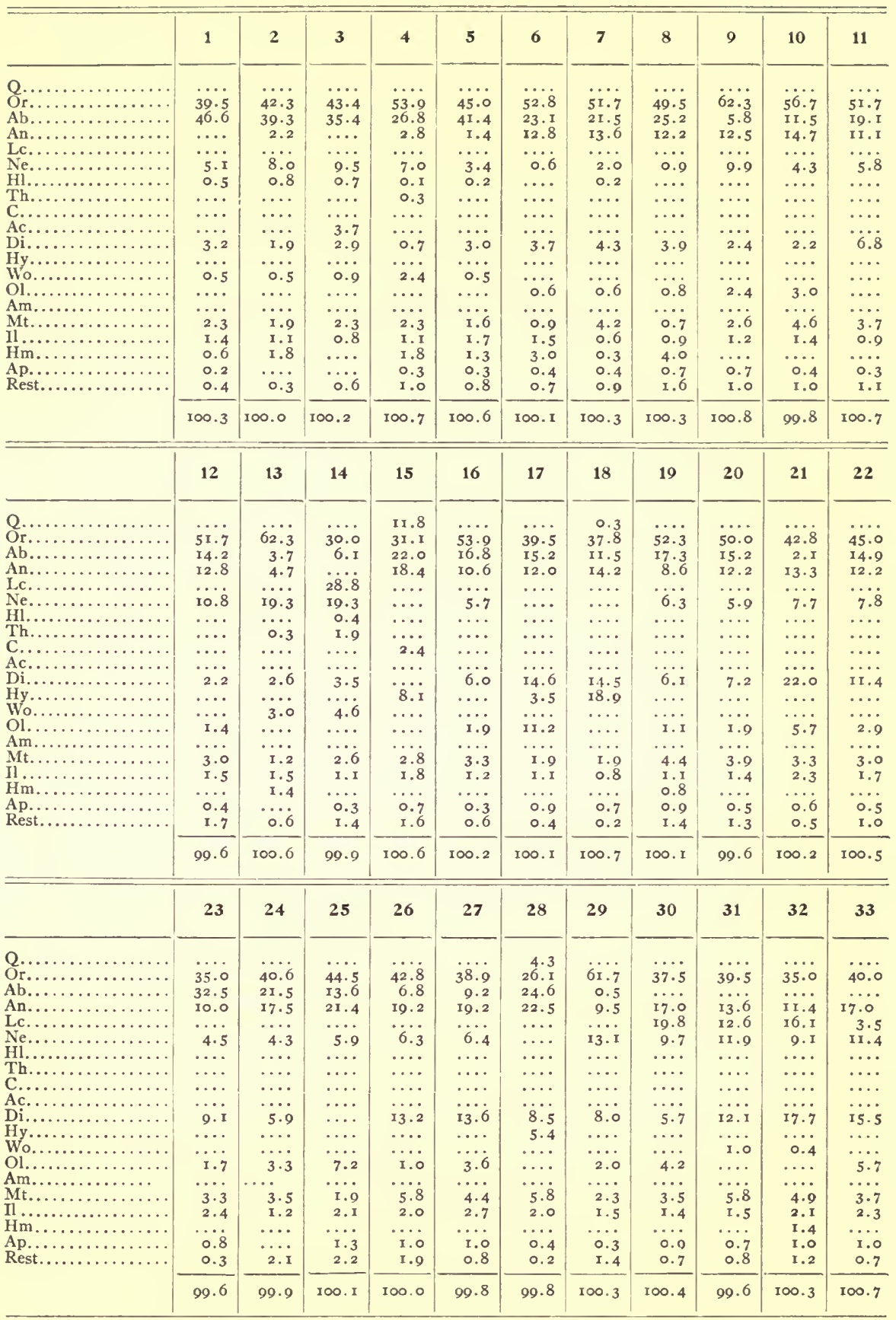


Norms of Roman Rocks-Continued.

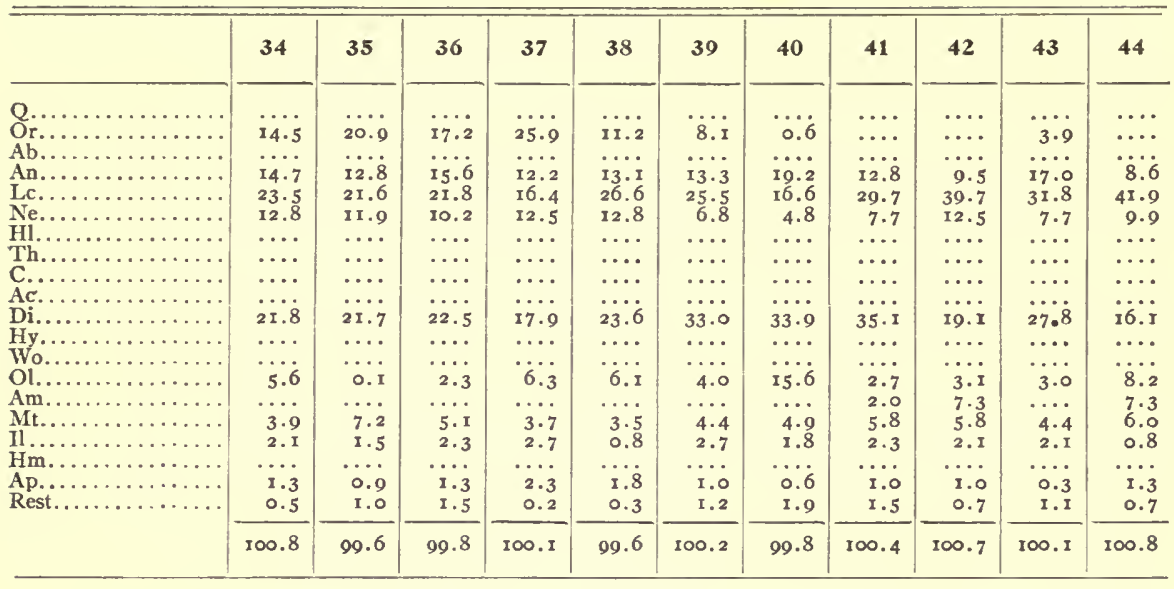

The first fact, and one of the most striking to be noted, is the rarity of quartz. This mineral is found only three times, in one case in notable amount in harzose, once in shoshonose, and again in negligible quantity in a ciminose. The feldspars make up very large percentages of nearly all the norms, except in the salfemanes (39-44) where they are largely replaced by lenads. Of the feldspars orthoclase and anorthite are the most constant, the former vanishing only in albanose (III. 8. 2. 2), and the amount of anorthite being negligible only in phlegrose (I. 5 . I. 3), beemerose (I. 6. I. 3), and appianose (I. 7. I. 3). It is worthy of note that the amount of this anorthite molecule is remarkably constant, for the most part about I 2 or I 3 per cent, though it may be higher or lower. Albite, on the other hand, while present in large amount in the persalanes (except appianose) and in the dosalanes belonging to the perfelic order germanare, disappears in the rocks of this latter class as soon as the lenads increase to notable amounts in vicose (II. 6. 2. 2), and from this on it is not found in the norm. With few exceptions it is very subordinate to orthoclase, though this is compensated for in many cases by the amount of nephelite.

Correlated with the poverty of the magmas in normative quartz (excess of silica) is the almost invariable presence of lenads, either nephelite or leucite or both. Apart from the norms which are quaric (15, 18, and 28), and where they can not exist, lenads are absent only in the norm of one rock, No. I7. Leucite is absent from the norms of all the persalanes except appianose, as well as from the perfelic dosalanes, and begins to appear in vicose (in which concomitantly normative albite is absent), whence to the most femic rock it is a constant normative constituent. Nephelite, on the other hand, is present in all the norms, except the five spoken of above, in which lenads are not present, and from vicose to albanose 
it is the only sodic mineral. Of the other lenic minerals, halite and thenardite (existing modally in sodalite and noselite or hauiyne) are found only in the persalanes, and of these only in the sodipotassic subrangs, phlegrose, beemerose, and appianose. In the dosalanes and salfemanes they seem to be entirely lacking.

The femic constituents need less discussion, as they are present in much smaller amount than the salic. This is especially true of the persalanes, in which the amounts of femic minerals are negligible. Of these it may only be said that acmite occurs but once, and that rocks falling in this class are about the only ones which show normative wollastonite, this being present generally when the subrang is sodipotassic.

Diopside is constantly present, being absent only in two cases, while normative hypersthene is rare, but this last can not, of course, be present in the norm along with the lenads. Olivine is almost as constantly present as diopside, and is absent only when there is normative quartz or wollastonite. The amounts of both of these vary considerably, but increase gradually though irregularly as the magmas become more femic. Magnetite, ilmenite, and apatite are always present, but in small amounts, and each varies within a very narrow range.

\section{Relations of Norm and Mode.}

The readjustments of the molecules of the norm to form the modes of the several types have been spoken of in each case in the preceding pages, but it will be instructive to summarize the main features.

In leucite-free types the readjustments are almost always of minor importance and the modes are essentially normative. In these the augite is the chief disturber of the normative relations, this alferric mineral taking some of the normative anorthite, and still less of the magnetite, ilmenite, and nephelite, to combine with the normative diopside. But as these non-leucitic types are only found in the persalanes and dosalanes, where the femic minerals are either negligible or subordinate, and as the amount of anorthite involved is only about one-fifth of the diopside (and that of the other minerals involved much less), the disturbance is seldom serious. It is noteworthy that wollastonite is more apt to be present in the norms of the persalane rocks than hypersthene or olivine, and this is probably connected with the presence of this mineral in the norm of the augite of the region when it is calculated into standard minerals. The high wollastonite in the norm of the tavolatal appianose [haüynitic leucite-tephrite, tavolatite] is of interest in connection with the occurrence of garnet in this rock.

In a few types characterized by the presence of biotite readjustments are needed for this mineral, involving normative leucite, olivine, and also anorthite to furnish the extra alumina in exact calculations. But here also the divergences from the norm are notable only in one or two cases. The reciprocal exclusion of biotite and leucite, so commonly observed elsewhere, is also evident throughout the region. Though there are a few cases where the two minerals do occur together, as in the 
type of teanal auruncose, it is generally observed that in rocks derived from identical or very similar magmas, while some contain biotite the others do not contain this mineral, but leucite and olivine replacing it. That is, the alferric biotite molecule has been split up actually into the simpler salic and femic ones.

By far the most important set of readjustments is that involved in the formation of leucite from magmas whose norms do not show this mineral. This topic will be discussed at some length on a later page, but it may be pointed out here that in these rocks the presence of leucite in such magmas involves the taking away of silica from normative orthoclase, which goes to form albite molecules from the normative nephelite, which albite enters modally into soda-lime feldspar. In a few cases some of the normative olivine seems to be involved, this becoming hypersthene which enters into modal augite. But this is exceptional, and in the majority of instances the readjustments take place between normative orthoclase and nephelite, forming leucite and albite in the mode, the normative minerals disappearing either in whole or in part.

The generally close correspondence between norm and mode among the nonleucitic rocks of the region, and the simple molecular readjustments involved in the formation of leucite, are of interest as bearing on the propriety of the choice of the so-called "standard minerals" in the quantitative classification. It has already been pointed out* that in the majority of igneous rocks there is, on the whole, a close correspondence between the norm and the mode in the majority of rocks; that is, that the readjustments of the norm needed for the mode are mostly of small amount and the modes normative. In his recent monumental work on Mont Pelée Prof. A. Lacroix $†$ points out that the standard minerals are "among those which are formed by (simple) igneous fusion followed by slow cooling, at the expense of those, such as the amphiboles, micas, and garnets, which are not so formed."

The practical absence of amphiboles, biotites, and the more complicated pyroxenes is certainly a striking feature of the region, and it would seem that for this igneous complex, at least, the choice of standard minerals is appropriate and expresses the modal facts as closely as any such selections could do.

\section{Mineralogical Characters.}

Introduction.-That the mineralogical composition or mode of igneous rocks is determined, within limits, by the chemical composition, subject to the physical conditions obtaining during solidification, is so well known that the statement is almost a truism. But it is found, furthermore, that in a comagmatic region the minerals present, or at least some of them, show certain more or less common peculiarities, which may be regarded as characteristic of the region, and which are usually looked upon as evidences of "consanguinity" only second to the chemical

* Cross, Iddings, Pirsson, and Washington, op. cit., p. I5I; and Washington, Prof. Paper U. S. Geol. Surv. No. I4, I903, p. 60.

† A. Lacroix, La Montagne Pelée et ses Éruptions, Paris, 1904, p. 529 
characters. In addition to the presence of certain minerals and their peculiarities, the absence of others which might be expected to be present, so far as the magmatic or normative characters permit, is another mineralogical characteristic of comagmatic regions.

Soda-orthoclase.-A constant feature of the alkali-feldspars of the region is that pure orthoclase seems never to occur, notwithstanding the highly potassic character of the magmas, the orthoclase molecule being invariably accompanied by notable amounts of albite, so that the alkali-feldspar is a soda-orthoclase. The orthoclase molecule, however, is nearly always present in larger amount than that of albite, the composition varying from $\mathrm{Or}_{6} \mathrm{Ab}_{\mathrm{I}}$ to (rarely) $\mathrm{Or}_{\mathrm{I}} \mathrm{Ab}_{2}$. As a common character it is notable that the microcline structure is never seen, and microperthitic intergrowths of orthoclase and albite are exceptional, while zonal structure is uncommon, the sections of the soda-orthoclase usually appearing uniform and homogeneous.

In habit the soda-orthoclase occurs either as phenocrysts, often of large size, and either prismatic, parallel to the clinoaxis $a$, or tabular, parallel to the clinopinacoid $b$ (oro), or as small prismatic laths (parallel to the axis $a$ ) in the groundmass. It may also rarely form an interstitial cement, and in some types occurs thus as a mantle of later growth around phenocrysts of soda-orthoclase or sodalime feldspar and oriented parallel with them.

It occurs most abundantly in the persalanes, especially in the phlegrose rocks, is common in the dosalanes, except in braccianose, where it is wanting, and is not found in the salfemanes. Its presence in the mode, therefore, would seem to be directly connected with the variations in the silica and the femic components.

Soda-lime feldspar.-The composition of this varies considerably, from andesine, $\mathrm{Ab}_{3} \mathrm{An}_{2}$, to an almost or wholly pure anorthite, but in the majority of the types it approximates to a labradorite, $A b_{1} A_{n}$. Multiple twinning is common, except in the groundmass laths of some types, according to the Carlsbad and albite, and less often the pericline laws. Zonal structure is not frequent, but, as said above, in some types phenocrysts of labradorite or anorthite are surrounded by mantles of orthoclase oriented like the nuclear crystal, that is, with the vertical axes and the clinopinacoids $b$ (ого) parallel.

The habits of these feldspars resemble those of the soda-orthoclase, but it may be noted that the phenocrysts of plagioclase are usually smaller than those of orthoclase, they are apt to be clustered into groups, and that groundmass laths are less common. These feldspars are rarely known to occur as an interstitial cement.

The modal occurrence of the soda-lime feldspars is exactly the opposite of that observed in the case of the soda-orthoclase. They are wanting in rocks belonging to phlegrose and other peralkalic subrangs of persalane, rare generally in the rocks of the persalane class, most common in the dosalanes, especially in braccianose, where they constitute the only feldspars, but, like the soda-orthoclase, are usually absent from the salfemic rocks. 
Leucite- - The abundance of this mineral is one of the most characteristic modal features of the region, and has made the volcanoes of the Bolsena-Vesuvius line famous in petrography. Apart from this it can not be said that the mineral offers any features specially peculiar to the region, as its characters here are those of many of its occurrences. In certain magmas, especially those belonging to vulsinose, ciminose, and vicose, it forms well-formed phenocrysts of very large size, up to 5 or $10 \mathrm{~cm}$. in diameter, which are characteristic of the viterboid habit. It may also occur in the groundmass as small crystals, sometimes well shaped and again mere spheroids, and rarely as anhedral patches. The larger individuals usually show the birefringence and twinned structure, which are commonly wanting in the smaller groundmass leucites. The larger ones also are usually relatively free from inclusions, while the characteristic regular arrangement of small inclusions in the groundmass, leucite microphenocrysts, and the frequent skeletal forms of these, are well known.

The occurrence of leucite in relation to the composition of the magma is an interesting topic, the discussion of which will be taken up on a later page.

Nephelite.-It is a somewhat striking fact that, while nephelite is found in the norms of nearly all the rocks, sometimes to a very large amount, it is seldom present modally in more than small quantities, not over Io per cent, most usually from I to 5 , and is often absent entirely, the soda entering the albite molecule to form a soda-lime feldspar. The typical occurrence of nephelite in the Roman Region is in the form of an interstitial cement, the last product of crystallization. Euhedral or even subhedral crystals are excessively rare, except in crevices in the rocks, where small, short prisms are fairly common in some types.

Sodalite minerals. - While these are met with in the rocks of the region, their occurrence can not be regarded as characteristic of it. For the most part their amount is very small, scarcely more than accessory, except in tavolatal appianose, where haüyne is one of the main constituents. Both sodalite and haüyne are found, but the former seems to be the more common.

Their occurrence is practically confined to the persalane rocks, and especially to the sodipotassic subrangs, the sodalites observed by De Lorenzo and Riva in the bolsenal vulsinoses [vulsinites] of the Astroni Volcano being very rare and sporadic, and corresponding to the occurrence of leucite in the blocks of cumal phlegrose [phonolitic trachyte] at the Vico Volcano or in the arsal monzonose [ciminite] at L'Arso.

Augite.-This alferric mineral is the one which is most characteristic of the region, and from the point of view of the alferric and femic minerals the region is decidedly an augitic one, as it is eminently a leucitic one from the salic point. It is invariably present in greater or less amount in all the rocks, without exception, the amount, of course, varying with the character of the magma as to the relation of salic and femic components. 
The composition would seem to be very uniform and may be represented by the analysis on p. I34 $_{3}$ and it is rather a diopside augite than one with the hedenbergite molecule abundant. In some, but not all, of the rocks belonging to sodipotassic subrangs the augite carries some ægirite, but the amount of this is usually small, and ægirite-augite must be regarded as rare or not prominent in the region.

The color of the augite is one of its most constant and characteristic features. While black or very dark green in the hand specimen, in thin sections it is almost invariably either colorless or a very pale grayish, occasionally slightly tinged with green or yellow. Only in some of the sodipotassic rocks does the color assume a true green, when it is pleochroic, and evidently contains some ægirite. But in the very great majority of the rocks, whether persalanes, dosalanes, or salfemanes, the typical color is the very pale gray, which may be said to be characteristic.

In this connection it is worthy of remark that, though the magmas of the region are rather high in titanium, and the augite analyzed by me contains 2.85 per cent of titanium dioxide, this mineral never shows the peculiar purple tones which are commonly supposed to be due to this oxide. A somewhat similar state of affairs has been observed by Pirsson in the Central Montana Region, as will be brought out later.

Hypersthene.-This mineral is one of the rarities of the region, and its absence, rather than its occurrence, is to be regarded as characteristic. It was only observed in the quaric and vitreous sorianal harzose, in colorless crystals, but is common in the quaric types of toscanose (I. 4. 2. 3) and amiatose (I. 4. 3. 3) at Monte Amiata, to the north of the Vulsinian District, the magmas of which may be connected with those of the Roman Region.

Biotite.-This mineral is likewise rare in the region, though more common than hypersthene. In some types, as sorianal harzose (II. 4. 3. 3) [biotite-latite], teanal auruncose (II. 5. 3. 2) [biotitic leucite-trachyte], and monfinal shoshonose (II. 5. 3. 3) [biotite-vulsinite], all of which, it is to be noted, are alkalicalcic, it is quite abundant and an essential component. In other types, as arsal vulsinose, ciminose (II. 5. 2. 2), and monzonose (II. 5. 2. 3) [vulsinite], it occurs in accessory amounts, and mostly as small interstitial patches. It is also met with, though as a rare accessory, in some of the types of braccianose (II. 7.2.2) at the Vesuvius Volcano. The color is uniformly a pale brown, with marked pleochroism.

There would seem to be some connection between the occurrence of biotite and that of olivine, the potential biotite molecule splitting up into leucite and olivine. A number of instances of this are mentioned in the descriptions of the types, and the subject has been discussed by the writer and other petrographers. On the whole the rarity of biotite, rather than its occurrence, may be regarded as the feature in regard to it which is most characteristic of the region.

Olivine.-Notwithstanding the rather low silica of many of the rocks this mineral is decidedly uncommon, though it is met with in small amounts in many of the dosalanes and salfemanes, and is characteristic of fiescolal ciminose (II. 5 . 
2. 2) [ciminite] and of fiordinal fiasconose (III. 7. 3. 2) [leucite-basanite], in which latter type it is abundant as large phenocrysts. It is also a frequent accessory in the various types at the Vesuvius Volcano, but is not as important or constant a constituent here as is often supposed. Its features are the usual ones and call for no comment, as they are not characteristic of the region.

Melilite.-While this mineral is, as usual, very rare, and is present in notable amount only in the type boval albanose (III. 8. 2. 2) [cecilite], its occurrence in these rocks may be noted as rather peculiar to the region. It would seem to be more widespread than has been thought, but any description of it is needless. In this connection its occurrence as an abundant and essential component of the cellal venanzose (IV. I ${ }^{5}, I^{3}$. 2) [venanzite] at the small cone of Pian di Celle, San Venanzo, Umbria, is worthy of attention, since this small cone is possibly connected with the main line of volcanoes.

Absence of minerals. - The most notable absentee is hornblende, which may virtually be said not to exist among the rocks of the region. Extremely small amounts of a barkevikitic hornblende are present in one or two types, and breislakite (which is usually referred to the hornblendes) occurs in the crevices of types of braccianose, vesuvose, and albanose in the Sabatinian, Latian, and Campanian Districts. But these occurrences are exceptional and do not invalidate the general statement that hornblende, as a true rock component, is absent from the region.

In view of the general character of the magmas and the fact that silica is scarcely ever in excess, the absence of quartz is not surprising, though it might be looked for among the harzose rocks. The majority of these are vitreous and show no quartz, but it has been observed among these rocks at the Cimino Volcano by Mercalli, though it does not seem to be common.

Among the more uncommon minerals, titanite is extremely rare, having been observed in only a few cases in very small amounts. Zircon is still rarer, and, indeed, no authentic occurrences are met with. The pyroxenic and hornblendic minerals which contain the oxides of the rare earths, such as lavenite, rosenbuschite, hiortdahlite, etc., are practically absent, lavenite occurring as a rare accessory in ischial phlegrose. This subrang is sodipotassic, and the general association of these minerals with magmas rich in soda is well known.

\section{Textural Characters.}

Although the textural characters are very largely determined by the conditions of solidification and are more remotely, if at all, dependent on the chemical composition of the magmas, so that they can only rarely and in a subordinate degree be considered as characteristic of a comagmatic region, there are certain features which merit a brief discussion.

As regards crystallinity the rocks of the Roman Region, which are wholly effusive flows, and their tuffs, are somewhat remarkable for the rarity of hyaline types. In the great majority of cases the rocks are holocrystalline, and this is 
especially true of the salfemanes and the more lenic dosalanes, among which the only hyaline types observed are small flows and the borders of larger ones at Mount Vesuvius. It is possible or probable that similarly vitreous portions existed originally at the other centers, but have been removed by erosion. In any case the volume of these is always small.

Glass appears in small amounts as the rocks increase in salic, and especially feldspathic, components, a little glass cement being found in some types of ciminose, vulsinose, phlegrose, etc. The most hyaline rocks belong to the subrangs phlegrose (I. 5. I. 3) and harzose (II. 4. 3. 3), and some types of the former are perhyaline obsidians. It is to be noted in these cases that the vitreous types of these two subrangs may and often do form massive flows and are not confined to small trickles of lava or outer borders of large flows. Probably connected with this tendency of these magmas to solidification before complete crystallization is the tendency of the harzose to form flow breccias and that of the phlegrose lavas of the Phlegrean Fields to form dustlike tuffs rather than solid flows.*

This tendency of the Roman magmas to form holocrystalline rather than hyaline types is probably connected with their generally high content in potash and lime. This view is borne out by the observed facts stated above, since the types of lenic orders of dosalane and of salfemane, which are uniformly holocrystalline, are relatively the richest in these two oxides, while the types of harzose and of phlegrose are relatively the poorest and are both sodipotassic. But further discussion of this topic is uncalled for, as it is rather a general one than characteristic of the region.

The abundance of phenocrysts is very noticeable, though this is not surprising in view of the fact that the rocks are effusive flows. It is more interesting to observe that the salic minerals, especially soda-orthoclase and leucite, are much more often phenocrystic than the alferric minerals, phenocrysts of augite and of olivine surpassing those of the salic minerals only exceptionally. The large size of the phenocrysts of soda-orthoclase and leucite has already been commented on. This tendency of the salic minerals to development in large crystals, while the alferric ones are small, is also evident in the rarity of megaporphyritic types among the rocks belonging to the more femic divisions, such as braccianose and albanose. In these the grain is uniformly small and megascopic phenocrysts are very rare and never attain large dimensions.

\section{Space Relations.}

For the discussion of the space relations or the geographical distribution of the different magmas and rock types it will be best to collate and summarize the statements made in the preceding petrographical descriptions as regards the occurrences in the several districts. These will be supplemented, so far as possible, by the descriptions of other petrographers, though in most cases it is difficult, if not

* Cf. Deecke, Geol. Führer durch Campanien, Berlin, 1901, p. 44. 
impossible, to translate these into the terms of the quantitative classification, on account of the lack of reliable analyses and the statement of the mode only in qualitative terms.

The data available on which to base the distribution of types and the characterization of each district vary widely. In some cases, as the Ciminian, the Latian, and the Campanian districts, they are satisfactorily complete and accurate. In others, as the Vulsinian and the Auruncan, they are as yet far from being complete, and in such cases the descriptions must be regarded as provisional.

\section{Vulsinian District.}

This district is not only the largest of all, but is the most complex in its volcanic structure, as has been seen, and, furthermore, shows the greatest diversity in its rocks. Of the seventeen subrangs known to be represented in the Roman Region at least eleven are found in this district, and some are confined exclusively to it.

Rocks of the persalane class are rather common and are represented by types of vulsinose (I. 5. 2. 2), pulaskose (I. 5. 2. 3), procenose (I. 6. 2. 3), and possibly beemerose (I. 6. I. 3). The types of vulsinose are non-leucitic, while those of the other subrangs mentioned are all leucitic, this mineral forming usually large phenocrysts. These persalic rocks are most common in the northern and northwestern parts, as around the Latera Volcano and near Bolsena. It is perhaps worthy of note that the subrang phlegrose (I. 5. I. 3), which is elsewhere common, is apparently unrepresented in the Vulsinian District.

The subrangs of dosalane are much more abundantly represented, and offer a greater variety of types. Of these subrangs ciminose (II. 5. 2. 2) is probably quite common in the northern portions. The leucitic bagnoreal type is found to the northeast of the lake, while non-leucitic types, as the fiescolal and arsal, seem to occur to the north. The alkalicalcic auruncose (II. 5. 3.2) is rare and is confined to the southern portion, so far as known. The lenic subrangs, vicose (II. 6. 2. 2), braccianose (II. 7.2.2), and vesuvose (II. 8.2.2), are more abundant, and to them belong many of the flows to the east, south, and southwest of Lake Bolsena. The types of these are invariably leucitic, rarely with large leucite phenocrysts, as in the viterbal vicose near Orvieto, but much more commonly quite without phenocrysts, or with only microscopic ones, as in the orvietal, galeral, and hernical types.

Rocks belonging to salfemane are almost, if not quite, as abundant as those in dosalane, but they are more monotonous in type. Of these magmas albanose (III. 8. 2. 2) is the most common and most widely distributed, occurring at various localities all around the lake, though mostly to the south. In general it is of the romal or saccal type, but the melilitic boval albanose occurs in the neighborhood of Montefiascone, southeast of Lake Bolsena. The only other subrangs of salfemane which are represented, jugose (III. 7. 2. 2) and fiasconose (III. 7. 3. 2), are rare and seem to be confined to the southeast portion. 
The magmas of the Vulsinian District are hence highly varied and the number of types large. Furthermore, there is evident a progressive change in composition from northwest to southeast. Thus the rocks of the northern and northwestern portions are very largely either persalane or dosalane, the former apparently the more common; those of the Bolsena and Capodimonte volcanoes on the northeast and southwest of the lake are predominantly in the dosalane class; while to the southeast, around the Montefiascone Volcano, salfemane rocks are the largely predominant ones; and furthermore, it is only in this portion that we find olivine and melilite entering into the mode to a notable extent. While this progression is not without exceptions and irregularities, and although my knowledge of the northern and northwestern parts of the district is not yet satisfactorily complete, the observations and collections which I was able to make seem to be sufficiently ample and the facts observed sufficiently concordant to justify the assumption that such a progressive magmatic change does occur. Our belief in the validity of this supposition is confirmed by the observation of similar relations in other districts.

Of the various subrangs, ciminose, vicose, and braccianose are probably the most abundant, with vulsinose and albanose less so, though still common. The other subrangs are of comparative unimportance, with the possible exception of vesuvose, pulaskose, and procenose.

\section{Ciminian District.}

The volcanic structure of this district is simpler than that of the preceding one, only two volcanoes being found, and these clearly distinct. Petrographically, also, the character is less complex, the number of subrangs represented being only seven.

Persalane rocks are abundant, though only two subrangs are represented. Of these cumal phlegrose (I. 5. I. 3) [phonolitic trachyte] is quite common in blocks about the Vico Volcano, though the total amount is probably small. On the other hand, vulsinose (I. 5. 2. 2) is very common, partly of the non-leucitic arsal type as flows and tuffs about the Cimino Volcano, and to a less extent around the Vico Volcano; partly of the pallanzanal type, known locally as "peperino," with small and not numerous feldspar and leucite phenocrysts at the Cimino Volcano; and very abundantly at the Vico Volcano of the viterbal type, with large leucite phenocrysts, though most of these rocks are more or less transitional toward ciminose.

The dosalane rocks vie with the persalanes in point of abundance. Heading the list systematically is harzose (II. $4 \cdot 3 \cdot 3$ ), the sorianal type of which is so common at the Cimino Volcano. The occurrence of this subrang here is noteworthy as the only quaric subrang found along the whole line of volcanoes of the Roman Region, if we except the Amiata Volcano, where toscanose (I. 4. 2. 3) and amiatose (I. $4 \cdot 3 \cdot 3$ ) occur.

The subrang ciminose (II. 5.2.2) is, with vulsinose, the most abundant of the district. The magnophyric non-leucitic arsal type [vulsinite] forms extensive 
flows about the Cimino Volcano. Leucitic types of ciminose are less common. The most so is the viterbal type [leucite-trachyte], to which some of the flows of the Vico Volcano doubtless belong, though most of them are in vulsinose. The less highly porphyritic bagnoreal ciminose [leucite-trachyte] and martinal ciminose [leucite-tephrite] are rarer, the former being represented only in the Monte Venere, the last eruption of Vico, and the latter by some flows on the northwest. The subrang monzonose (II. 5. 2.3) is a rather rare one, and forms only a few flows in the southern portion of Vico. On the other hand, the subrang of vicose (II, 6. 2. 2) is abundant, always of the viterbal type [leucite-tephrite], and forms numerous flows of the Vico Volcano.

From the above it is clear that the older Cimino Volcano to the northeast is composed almost wholly of harzose, vulsinose, and ciminose, the types of these being non-leucitic without exception, so far as known. The Vico Volcano has, as the predominant magmas, vulsinose, ciminose, and vicose, with some phlegrose, and small quantities of monzonose, leucitic types being somewhat predominant. As a whole, then, the district is comparatively simple magmatically, and, as we shall see later, the most abundant magmas are those-vulsinose, ciminose and vicose-which are nearest the average composition of the whole region. It is especially noteworthy that none of the subrangs, as braccianose and vesuvose, belonging to the more lenic orders are found, and that the salfemanes are wholly unrepresented.

We find here also evidences of progressive magmatic change in the rocks of Cimino and Vico, the former being as a whole considerably more salic and higher in silica than those of Vico. At each individually there does not seem to be any definite spatial distribution, a condition to be expected when it is considered that in each case there was apparently but one outlet for the flows.

\section{Sabatinian District.}

This district resembles the Vulsinian in the complexity of its volcanic structure, as well as in the range of its subrangs, though magmatically there are some striking differences.

The persalane class is comparatively rare, neither phlegrose nor vulsinose, which are so common in the northern districts, being met with here. Of this class the only subrang is beemerose (I. 6. I. 3), the sabatinal type of which [leucite phonolite] occurs in the northern portion. Of dosalane the subrang ciminose (II. 5. 2. 2) is wholly unknown, but vicose (II. 6. 2. 2) is rather common in several types [leucite-tephrite], both to the west and the east of Lake Bracciano. Of the subrangs of dosalane, braccianose (II. 7.2.2), almost always of the galeral type [leucitite], is by far the most common and, indeed, the most characteristic of the district. To this division belong nearly all of the extensive flows south of Lake Bracciano, as well as some to the east and west. The subrang vesuvose (II. 8. 2. 2) is also rather common, likewise of the galeral type [leucitite], and is met with in the northerly parts of the district. 
The salfemane class is much less abundantly represented, the only subrang being albanose (III. 8. 2. 2), of the romal, saccal, or boval types [leucitite], and is met with at several points about the lake, both north and south.

It is seen that this district is comparatively simple magmatically, the largely predominant subrangs being braccianose and vicose, with relatively small amounts of beemerose, vesuvose, and albanose, while the total absence of such widespread subrangs as vulsinose and ciminose is very remarkable. Another important characteristic is the fact that the types are invariably leucitic, which is probably connected with the uniformly lenic character of the subrangs, though some of these, as beemerose and vicose, assume non-leucitic modes elsewhere.

Although the more northern and much of the eastern portions of this district are inadequately known, yet the general distribution of magmas described above would lead us to suspect that here, as at the Vulsinian District, there is a progressive magmatic change from north to south, the femic constituents increasing and the silica diminishing in this direction.

\section{Latian District.}

This small district, with a comparatively simple volcanic structure, is even more uniform in its eruptive products than the one just described. The persalanes are represented only by the very rare tavolatal appianose [haüynitic leucitetephrite], which is found only as blocks in tuff. Of the dosalanes only one subrang can be surely identified, that of braccianose (II. 7.2.2), to the hernical type of which [leucitite] many flows can be referred. The salfemanes are probably the most abundant, but all belong to one subrang, albanose (III. 8. 2. 2), mostly of the romal and saccal types [leucitite], but in some cases of the melilitic boval type [cecilite].

The district is thus very monotonous, and is notable for the highly femic character of its products and their large content in leucite, as well as for the total absence of non-leucitic rocks.

\section{Hernican District.}

This very small district resembles the Latian in the general character and uniformity of its rocks. None belonging to persalane occur, nor are ciminose or vicose represented among the dosalanes. Of the rocks of this class the majority fall in braccianose (II. 7. 2. 2) [leucite-tephrite], with a few probably in vesuvose (II. 8. 2. 2) [leucitite] and one probably, though doubtfully, in fiasconose (II. 7 . 3. 2) [leucite-basanite]. The subrang albanose (III, 8, 2, 2) of salfemane is apparently as common as braccianose, the rocks being of the saccal type [leucitite].

\section{Auruncan District.}

As our knowledge of the rocks of this district is far from complete, a description of it must be regarded as provisional and subject to future corrections. The persalane rocks seem to be quite common, two subrangs being represented, 
phlegrose (I. 5. I. 3), of both the ischial and cumal types [trachyte], and vulsinose (I. 5. 2. 2), of the bolsenal type [vulsinite]. Apparently the majority of the rocks belong to the dosalane class. Of this the subrang ciminose (II. 5. 2. 2) is rare, while auruncose (II. 5. 3. 2) is abundant, two types [leucite-tephrite] being represented, both of which are leucitic and one carrying considerable biotite. The subrang shoshonose (II. 5. 3. 3), while not abundant, is important, as the monfinal type of this magma [biotite-vulsinite] forms the central mass of Monte Santa Croce. Viterbal vicose (II. 6. 2. 2) [leucite-tephrite], with abundant large leucite phenocrysts, is common, probably as much so here as at the Ciminian District. While no rocks falling in braccianose, vesuvose, or in the salfemane class were collected by myself, it would seem from some of the published descriptions that such do occur, and probably rather abundantly, in the western part of the district. These are leucitic and presumably of types found elsewhere [leucite-tephrite and leucitite]. In addition some non-leucitic types [basalts] are described, but in such vague terms that nothing definite can be established as to their magmatic character, except that they are almost certainly in dosalane, and probably in the perfelic order germanare.

From these meager data it is at least clear that the rocks of the Auruncan District are very diverse in character, the magmatic range being almost as great as at the Vulsinian District, and both leucitic and non-leucitic types being abundant. But it is evident that much more study is needed before this volcano can be satisfactorily characterized.

\section{Campanian District.}

This district embraces three quite distinct centers of volcanic activity; the Vesbian Volcano, including the older Somma and the later Vesuvius, the volcanic complex of the Phlegrean Fields, and the island of Ischia, which is essentially the Epomeo Volcano, with its parasitic cones. The rocks of Vesuvius and Somma are remarkably uniform, most of them falling in braccianose (II. 7.2. 2), with fewer in jugose (III. 7. 2.2) and vesuvose (III. 8. 2.2), several different types [leucite-tephrite] being represented. The Phlegrean Fields and Ischia are similarly uniform, though here the character of the magmas is quite different. In these two subdistricts the rocks are practically all in persalane, and by far the most predominant subrang is phlegrose (I. 5. I. 3), which is represented by several texturally different types [trachyte]. Bolsenal vulsinose (I. 5. 2. 2), pulaskose (I. 5. 2. 3), and monzonose (II. 5. 2.3) [vulsinite] are found, but in small amounts comparatively, and some leucitic types of unknown subrangs occur, but always as blocks and in negligible quantity.

The Campanian District, then, is composed dominantly of but two subrangs, phlegrose and braccianose, the points of eruption of these being distinctly separated, though these very diverse magmas have been erupted simultaneously at times. 


\section{Distribution of Magmas.}

It is well known through recent researches that a number of igneous masses of large dimensions, as laccoliths, show a very pronounced change in chemical and other characters as one goes from the center to the periphery, the change being sometimes from more salic to more femic, and sometimes the reverse. These changes are usually held to be the results of local or laccolithic differentiation, and typical cases have been discussed by Brögger, Pirsson, and the writer. Similarly in a number of instances there have been observed such progressive changes extending over petrographic provinces or comagmatic regions of large area, the most detailed being that of central Montana, recently described by Pirsson.

Although it may seem at first glance that there is no progressive change in the rocks of the Roman Region, but that the different districts show an irregular alternation of magmatic characters, study reveals strong evidence of a regular progression from each extremity to the center. In considering this matter some peculiarities of the Roman Region must be borne in mind. In the first place, it does not cover an area extended in all directions, as in the central Montana, Christiania, Bohemia, and other well-known regions, but rather consists of a long, narrow line or band, with very few occurrences of igneous rocks on either side of the main line, and those very small. In the second place, the occurrences are entirely volcanic, that is, effusive and superficial, the few dikes being in the masses of volcanic cones, and hence analogous rather to lava flows so far as their bearing on problems of differentiation go, deep-seated dikes penetrating the country rock and plutonic or deep-seated masses in general being wholly unknown. A third consideration is that the various centers are strung along the line somewhat irregularly and often with very notable spaces between them.

When we study the descriptions of the different districts given above several points are brought out.

The districts at the extremities, the Vulsinian and the Campanian, are the most complex vulcanologically, those inside of these, the Ciminian, Sabatinian, and Auruncan, somewhat simpler, though still complex, and the innermost, the Latian and Hernican, the smallest and the simplest of all.

Concomitantly with this progressive change in vulcanological structure, though whether causally connected or not need not be here considered, is a more or less regular change from ends to center in the variety of the magmas represented. Thus the Vulsinian District shows a very great diversity of magmas, varying from persalic to salfemic ones, and with orders running from perfelic to feldolenic, while, on the other hand, the rangs are consistently domalkalic and the subrangs are mostly dopotassic. At the other extremity we find at the Campanian District a similarly wide diversity of magmas from perfelic phlegrose to braccianose, though here the number is not as great, the Vesbian Volcano being almost wholly of braccianose, while the Phlegrean and Epomean Volcanoes are almost entirely of phlegrose, near the border of nordmarkose. The penultimate districts, the Cimin- 
ian and the Auruncan, are almost as complex and great in range, especially the Auruncan, while the Ciminian is distinctly somewhat simpler and with a smaller range, the more lenic orders of dosalane and the salfemanes not being found here. The three central districts, the Sabatinian, the Latian, and the Hernican, are each much more simple magmatically than the external pairs, the Sabatinian being the more complex, while the Latian and Hernican both show only a very limited range of magmatic variation. It is thus seen that, while certain irregularities are evident, there is on the whole a marked increase in magmatic range and complexity from the center to the extremities of the line.

Corresponding with this variation another makes itself manifest, though the data on which it is based are less readily and satisfactorily determinable. If we estimate the average composition of the magma of each district we find that here also there is a distinct and definite variation between center and ends. This estimation may be carried out in two ways, either by weighting the different chemical analyses of the rocks of each district according to the relative amounts and taking the mean, or more roughly, though more expeditiously, by expressing the average composition, regard being had to the relative abundance of the different magmas at each center, in terms of the magmatic position as expressed by the quantitative system of classification. In view of the lack of data and imperfect knowledge of many of the rocks in some districts, as well as of their relative amounts, the second method would seem to be adequate for present purposes.

The estimates below are based largely on my own observations, as well as on the published descriptions of others, so far as they could be applied, though the details can not be gone into here, and while the results are admittedly but roughly approximate, they may yet be considered to be sufficiently accurate to enable us to judge the main features with confidence. Of these estimates those for the Vulsinian, Sabatinian, and Auruncan districts are the least reliable, while those of the others are based on fairly complete and satisfactory data.

\title{
Average Magmas of the Districts.
}

\author{
Vulsinian: Vicose (II. 6. 2.2) or ciminose (II. 5. 2. 2). \\ Ciminian: Ciminose (II. 5. 2. 2) or vulsinose (I. 5. 2.2). \\ Sabatinian: Braccianose (II. 7.2.2). \\ Latian: Braccianose (II. 7.2.2) or vesuvose (II. 8. 2. 2). \\ Hernican: Braccianose (II. 7. 2. 2) or albanose (III. 8. 2. 2). \\ Auruncan: Ciminose (II. 5. 2. 2) or monzonose (II. 5. 2. 3). \\ Campanian: Borolanose (II. 6. 2. 3).
}

Assuming that these are true or not far from the truth, and with the knowledge of the chemical composition and norms of the various types shown by the numerous analyses presented on a previous page, it is clear that the average magmas at the ends are more salic and less lenic and femic, that is, higher in silica than the central ones, which are very distinctly higher in femic constituents (especially magnesia and iron oxides) and lower in silica. 
Expressed mineralogically and in terms of the prevailing systems of classification, we find toward the ends of the line an abundance of non-leucitic rock types, trachytes, vulsinites and ciminites, with leucite-trachytes, leucite-phonolites, leucitetephrites, and some leucitites; while at the central districts, the Sabatinian, Latian, and Hernican, we find no non-leucitic types, that leucite-trachytes and leucitephonolites are rare, and leucite-tephrites of the more basic types and leucitites are largely predominant.

A secondary progression, but in the same direction, is indicated by the local distributions observed at the Vulsinian, Ciminian, and Sabatinian districts, namely, that in each the southern portion is more femic and more lenic (less high in silica) than the northern. These have been already spoken of in preceding pages. It is needless here to go into details, but there is little doubt that as the volcanic foci shifted in these districts there was a progressive variation in the general magmatic characters of the erupted rocks. In the southern half of the region this is not as well marked, though we find here a magmatic division of the districts. Thus the more femic magmas seem to occupy the western and southwestern parts of the Auruncan District, while in the Campanian the more salic and more femic magmas are more sharply distinguished, the former constituting the western and the latter the eastern part.

It would appear also that, while the central districts are very preponderatingly dopotassic, the exterior districts are less so and tend more to being sodipotassic; that, in other words, there is a progressive increase of soda relatively to potash from the center outward. This is shown by the occurrence of rocks belonging to sodipotassic subrangs, as phlegrose (I. 5. I. 3), pulaskose (I. 5. 2. 3), procenose (I. 6. 2. 3), harzose (II. 4. 3. 3), monzonose (II. 5. 2. 3), and shoshonose (II. 5 . 3. 3) in the Vulsinian, Ciminian, Campanian, and Auruncan districts, while rocks belonging to sodipotassic subrangs are wholly wanting, or found only sporadically in the three central ones. The fact that the phlegrose rocks of the Campanian District are almost dosodic and near the border of nordmarkose, while those of the Vico Volcano are centrally sodipotassic, also points to similar relations.

While it must be, and indeed freely is, admitted that the data on which the above conclusions rest are not complete, they are sufficiently so, in the judgment of the writer and in view of the descriptions and analyses found in the preceding pages, to warrant belief in a regular and symmetrical distribution of the magmas in the Roman Region, in which the central magmas are not only less varied and complex, but are more femic and lenic, lower in silica, and with potash relatively much higher than soda, than obtains in the districts toward both extremes of the line.

Although anticipating a point which will be brought out later, it will be of interest to note here that the average composition of the regional magma as a whole is probably a ciminose-vicose (II. 5-6. 2. 2); that is to say, that the average exterior magmas are of about the composition of the original, or proximately original, magma, while the central ones show compositions approaching the more femic extremes of differentiation. 
Progression of Types.

In a recent paper* Pirsson calls attention to a phase of the occurrence of the rock types in Central Montana Region, to which he applies the name of "Regional Progression of Types." The idea to be expressed by this term is that in traversing a given comagmatic region certain types, from being sporadic, become frequent and then disappear, the rare types of one district or portion of a region becoming the common ones of other portions. As he says that "it would be a matter of interest to know if this progression of types is a peculiarity confined to this (Central Montana) province and occasioned by the local distribution of magmas, or whether it is of more general application," and as he suggests the region of central Italy as one in which it is likely to be observed, it will be well to examine our region briefly from this point of view.

It may be stated at the outset that a similar progression does seem to exist, though not as clearly cut in many ways, as seems to be the case in the Montana one. This is possibly due to the fact that in the Italian region the rocks are entirely extrusive. As instances of the kind the following may be mentioned:

The galeral and hernical types of braccianose and the romal and saccal of albanose [leucitites] occur in abundance, and form the majority of the flows in the Hernican and Latian and the southern part of the Sabatinian Districts. To the south of the first of these, these types are rather common, though somewhat sporadic, in the Auruncan District, but are quite absent in the Campanian, the types of braccianose here being quite distinct. To the north these types are unknown in the Ciminian District, but reappear in the Vulsinian, especially in the southern part, to die out in the northern.

The ischial and cumal types of phlegrose [augite-trachyte] are most abundant in the western part of the Campanian District, they (especially the cumal) are rather abundant but sporadic in the Auruncan District, disappear in the central ones, to recur as the scattered blocks of cumal phlegrose in the Ciminian. Similarly, but in a reversed direction, the arsal types of vulsinose and monzonose (vulsinite) are fairly common in the northerly Vulsinian District, attain a maximum in the Ciminian, are lost in the three central districts, occur in the Auruncan, and are very rare in the Campanian.

The types with the characteristic viterboid habit, viterbal vulsinose, ciminose, and vicose [leucite-trachyte], show a closely similar distribution. Occurring rarely in the Vulsinian District, they form the most prominent rocks of the Vico Volcano in the Ciminian, vanish in the central districts, and are rather common in the Auruncan, though they do not reappear in the Campanian.

These are the most prominent examples, though others might be given or can be found by the reader by examination of the descriptions of the types, and they show clearly that a progression of types does exist in the Roman Region, and that such a phenomenon is not local and a peculiarity of the Central Montana Region,

* L. V. Pirsson, Am. Jour. Sci., XX, 1905, p. 48. 
but one which is widespread and probably to be observed elsewhere, now that attention has been directed to it.

\section{The Rocks of the Tuscan Region.}

In this connection a few words may be devoted to the relations of the rocks of the volcanoes making up the Tuscan Region to those considered in this paper. It has been mentioned that these volcanoes are all of rather small size and area, their eruptions being apparently of the domal type, and that they lie close to the area of the Roman, but exterior to it, on the north and west.

It is unnecessary here to go into descriptions of the rocks, which will be found in several publications mentioned in the bibliography, especially in Nos. 4, 15, 43, 62 , and 65. It must suffice to say that the rocks are quite uniform in character, mostly toscanites or quartz-trachyandesites in the prevailing nomenclature, while in the quantitative classification they fall in dellenose (I. 4. 2. 2), toscanose (I. 4 . 2. 3), or amiatose (I. $4 \cdot 3 \cdot 3)$.*

This general uniformity, or rather comparatively restricted range in chemical composition, their persalic and quardofelic characters, and the prevalence of sodipotassic subrangs are features which fall in line with the general course of the distribution of magmas in the Roman Region, where we have just noted the more salic, felic, and sodipotassic characters of the exterior portions as contrasted with the central ones. It suggests the thought that these Tuscan rocks may belong to the same general body of magmas as those of the Roman Region, and that they represent in fact the extreme exterior differentiation products.

While this hypothetical magmatic connection is very tempting, it must be noted that a serious objection to it lies in the fact that the volcanoes of the Tuscan Region are apparently all of about Eocene age, while those of the Roman Region are much later, belonging to the Pliocene or even modern times.

Whether this objection on the score of time relations is a valid one or not, we are scarcely in a position to judge as yet, though consideration of the very great time intervals involved would seem to render the objection to the hypothesis of more weight than the chemical and petrological evidence in its favor. At the same time it may be mentioned that the actual time interval between the earliest and the latest of the eruptions in the Roman Region, which are undoubtedly connected magmatically, is itself very great, so that possibly the objection raised here is not of such a serious character as might appear at first sight. At any rate, the hypothesis here presented may be borne in mind in further studies of the Italian volcanic rocks.

\section{Quantitative Relations.}

In any comagmatic region where the igneous rocks are all effusive it is in a high degree improbable that they represent, in the aggregate, the composition of the original magma from which they have been derived. This is so since, assuming

* Cf. Washington, Prof. Paper, U. S. Geol. Surv. No. 14, 1903, pp. 159, I7I, I85. 
the existence of some deep-seated "reservoir," "magma-basin," or other body of magma as a source, it is highly improbable that these extruded portions form more than a small fraction of the whole, or that their relative proportions when averaged are such as to give a correct idea of the true composition of the magma whence they are derived. It is probable that the body of extruded rock is very small relatively to the parent body and that it consists for the most part of only a certain, and not wholly representative, portion of the differentiates.

The above conclusions would also hold good, though probably to a less extent, of regions where the erosion has been profound, so that the deep-seated rock bodies, as stocks and laccoliths, are exposed, with their satellites of dikes and sometimes of flows. In most cases it is probably true that here erosion has destroyed a very considerable portion of the masses, especially of the effusive portions, while again it has not progressed far enough to reveal the deeper portions, and we are left in the dark as to the downward extensions.

In both cases the practical difficulty of estimating the relative masses of the various types is a serious one. In certain small bodies, as some differentiated dikes or small and deeply eroded laccoliths, as that of Shonkin Sag, exceptionally favorable conditions may almost entirely overcome the inherent difficulties, and very reliable estimates can be made. But in the great majority of cases the difficulties are almost or quite insuperable, and we must perforce remain content with such approximate estimates as the erosion and exposures permit.

But notwithstanding the impossibility in most cases of arriving at perfectly satisfactory or trustworthy data, the problem of the composition of the original magma is of such interest in the study of comagmatic regions, and has such important bearings on the phenomena of differentiation, that an attempt should be made to determine it wherever possible, even though the results arrived at must be regarded as of no very high order of accuracy and provisional in their character. As such observations increase in number and cover more kinds of comagmatic regions or differentiated bodies, their value will increase, even though they be not absolutely accurate, since in any case they will probably point out the directions in which the processes of differentiation take place, if not their extent. We shall at least gain some general knowledge, though all the details are unknown to us.

In the case of the Roman Region, as much of it is as yet unmapped geologically, and in any case the thicknesses of the various flows are quite unknown for the most part, as well as many of them certainly covered beyond our observation by later flows and tuffs, the possibility of detailed knowledge of relative masses is reduced almost to a minimum. The only basis on which I can estimate them at present are my general observations, and the published statements of others, as to the relative abundance of the various types which are accessible to study, the relative areas of the different districts being also taken into consideration. We shall begin, therefore, with a general examination of the quantitative relations of the different 
magmas, the spatial relations of the different magmas and types being discussed elsewhere, and shall then attempt to estimate the average composition of the whole.

\section{Quantitative Relations of the Magmas.}

The persalanes, while widely distributed, are not the most abundant rocks, forming possibly but one-quarter or one-third of the whole. The great majority belong to the perfelic order canadare, rocks of the lenic orders russare and tasmanare being rare. For the most part they are domalkalic, either vulsinose or pulaskose, the former subrang being the more abundant, with the peralkalic and sodipotassic phlegrose in greater amount than pulaskose but less than vulsinose.

The dosalanes constitute the greater part of the rocks, one might say rather more than one-half. Of these those belonging to the quaric order austrare are very few, the perfelic germanares are very abundant, and probably in somewhat greater amount than these last are collectively the lenic norgares, italares, and campanares. By far the most of the rocks which fall in this class are domalkalic, with fewer alkalicalcic and no peralkalic or docalcic ones. The subrangs are generally dopotassic, though sodipotassic subrangs are not unusual, but are generally confined to the less common types. Of the subrangs of dosalane it may be said that ciminose, braccianose, and vicose are most abundant, with less amounts of monzonose and vesuvose, the others being comparatively rare.

The salfemanes are less abundantly represented than either of the other two classes, and probably considerably less than a quarter, let us say one-fifth, of the rocks belong here. With few exceptions the salfemane rocks are in the lendofelic order of bohemare, and of the subrangs of salfemane that of albanose is undoubtedly the most abundant.

Summing up the above, we may make the following roughly quantitative statement, in which the relative abundance of the subrangs, in the judgment of the writer, is that of the order in which they appear. It would be impossible to give more exact quantitative data without very minute and detailed study of all the districts.

\section{Order of Abundance of Subrangs.}

Abundant.-Ciminose (II. 5. 2. 2), braccianose (II. 7. 2.2), vicose (II. 6. 2. 2), vulsinose (I. 5. 2. 2).

Common.-Albanose (III. 8. 2.2), phlegrose (I. 5. I. 3), monzonose (II. 5. 2. 3), vesuvose (II. 8.2.2). Rare.-Pulaskose (I. 5. 2. 3), auruncose (II. 5. 3. 2), harzose (II. $4.3 \cdot 3$ ), shoshonose (II, 5 . 3. 3), jugose (III. 7. 2. 2), beemerose (I. 6. I. 3).

Very rare.-Procenose (I. 6. 2. 3), fiasconose (III. 7. 3. 2), appianose (I. 7. I. 3).

The reliability of these relative positions varies much. Thus the first four are undoubtedly easily the most abundant, but the orders of ciminose and braccianose, and of vicose and vulsinose, are open to question. The same is true of the "common" magmas, which collectively should follow the "abundant" ones, though there may be some question as to the relative abundance of albanose and phlegrose, 
or of monzonose and vesuvose. Similar criticisms could be made of the rare and very rare magmas, though the positions of the last two are almost certain, but all of these are so exceptional that they have little bearing on the immediate problem.

The Average Magma.

As we have seen that the relative amounts of the different subrangs vary greatly, from those which are very abundant to those which are only met with exceptionally, it is clear that the composition of the whole, or of the original magma, can not be arrived at by simply taking the average of all the analyses. This would lead to correct results if the number of analyses of each type were proportional to its relative abundance or less accurately to the number of occurrences. But as this is not true we must, in our final calculation, weight the analyses of the rocks belonging to each type or subrang according to the relative abundance as best we may. This is a somewhat difficult proceeding, and in the nature of the case and the absence of exact quantitative data, must be somewhat arbitrary and depend largely on the judgment of the calculator. The matter has been the subject of considerable thought and numerous calculations, the latter indicating that the range of possible variation in different directions was much smaller than had been thought probable, and it was also found that the influence of small amounts of the rarer magmas was almost, if not quite, negligible.

As a final basis of calculation it was decided to employ only the more abundant magmas, the relative amounts of which could be approximately estimated with a fair degree of satisfaction. The introduction of the rarer ones into the calculation must be regarded as a small correction, to be applied in the future, when the main data are more accurately known. To a certain extent also these rarer magmas are of such characters that they compensate for each other more or less, so that their introduction or neglect does not seem to affect the final result seriously.

The magmas selected for use were ciminose (II. 5. 2. 2), braccianose (II. 7 . 2. 2), vicose (II. 6. 2. 2), vulsinose (II. 5. 2. 2), albanose (III. 8. 2. 2), phlegrose (I. 5. I. 3), and monzonose (II. 5. 2. 3). The average of the analyses of the rocks of the various types which fall in each of these* was calculated, and each average was weighted as follows: Ciminose, braccianose, and vicose $=$ weight 5 ; vulsinose $=$ weight 4 ; albanose, phlegrose, and monzonose = weight 2 .

It would have been well to include vesuvose, with a weight of 2 , but no chemical analysis of this was a vailable, and it is probable that its neglect is compensated for by the possible greater abundance of phlegrose over albanose. Also, it might have been somewhat more accurate to include pulaskose, auruncose, and harzose with a weighting of I each, but it was thought that this was giving these rather rare magmas undue importance, and it was found that a less relative weighting had but little effect on the final result.

In any accurate estimate corrections for the specific gravities of the different types should also be made. But the data in regard to the relative abundance are so rough in themselves that this was deemed to be an unnecessary refinement.

* Except that of the viterbal vulsinose from below San Rocco, at the Vico Volcano (cf. p. 39). 
Calculating the average on the bases given above, and neglecting water and the minor constituents except $\mathrm{TiO}_{2}$ and $\mathrm{P}_{2} \mathrm{O}_{5}$, the following results were obtained:

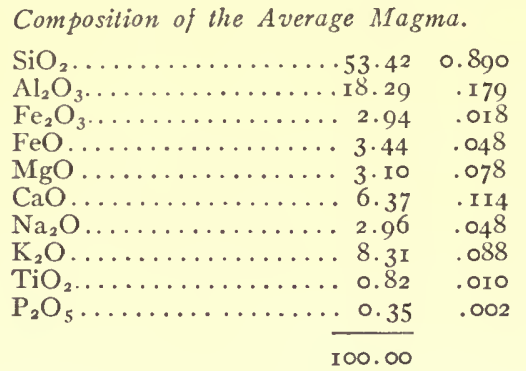

Norm of the Average Magma.

Or...........48.93)

Ab..........4. 4. 72$\} 65.60$ )

An ................ $\}_{76} 6.68$

$\mathrm{Ne} \ldots \ldots \ldots \ldots \ldots$ II. 08 Ix.08

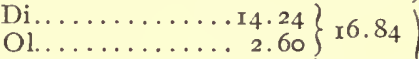

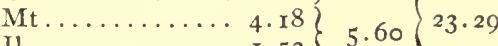

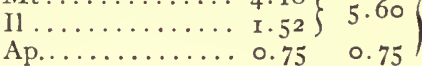

$99 \cdot 97$

According to this calculation the average or original magma falls almost exactly at the center point of dosalane, is fairly well within the lendofelic order norgare, though somewhat close to the border of the perfelic germanare, is almost exactly at the center point of the domalkalic rang essexase, and is well within the borders of the dopotassic subrang vicose. It is thus a vicose (II. 6. 2. 2), somewhat approaching a ciminose (II. 5. 2. 2), though not sufficiently closely to be called a ciminose-vicose. Its general composition is therefore that of two of the most abundant subrangs, and it is clear that the influences of the others which were introduced into the calculation have largely counterbalanced each other, the persalanes the salfemanes, the perfelic orders those which are more lenic, and the peralkalic rangs those which are alkalicalcic, while the sodipotassic subrangs reduce slightly the markedly dopotassic character of the others.

None of the rocks which were analyzed have exactly the same composition, though the analyses of bagnoreal ciminose and viterbal vicose most resemble it in general features. In the former, however, the silica is a little higher (the order being perfelic on this account), and the bivalent oxides are lower, while in the vicose analyses alumina is a little higher and potash considerably so.

When the position of this average analysis is referred to the diagram given farther on (p.I84), it is seen that it falls almost exactly in the middle of the gap between $\mathrm{SiO}_{2}=52.40$, and the critical group, with a ratio of $\frac{\mathrm{SiO}_{2}}{\mathrm{~K}_{2} \mathrm{O}}=\mathrm{IO}$. I I, or almost exactly the average one. It would seem from these facts that the composition as calculated must approximate very closely to the true average of the effusive rocks so far as they are known.

It is worthy of remark that rocks belonging to vicose and ciminose, or which approach the average in chemical composition, occur only in those districts where there is the greatest variety of magmas, namely the Vulsinian, Ciminian, Sabatinian, and Auruncan, and which, furthermore, we have reason to believe are the oldest. They seem to be entirely wanting in those districts where the rocks are more uniform in character, the Latian and the Hernican, as well as in the Cam- 
panian District with its two subdistricts, each of very uniform rocks, the one highly salic and perfelic, and the other more lenic and more femic than the average.

We have also seen in the discussion of the space relations of the types and magmas that the average compositions of the outer districts, the Vulsinian, Ciminian, Auruncan, and Campanian, are probably very close to that of the average magma of the region as a whole. In the first three of these districts the relations are too complex and the number of types too great to allow of very satisfactory estimates. But in the comparatively simple Campanian District there seems to be a possibility of testing this statement by calculation. For this district the average has been arrived at by taking the average of the three analyses of Vesuvian lavas given in the table to find the composition of the Vesuvian magma. That of the Phlegrean and Ischian magma was found by taking the average of the analyses of the phlegrose rocks of the district, and of the vulsinose and monzonose rocks of Astroni and L'Arso, and weighting these in the proportion of 5 to $\mathrm{I}$, as the phlegrose rocks are much the most abundant. These two averages were then averaged by taking equal parts, with the results here given.

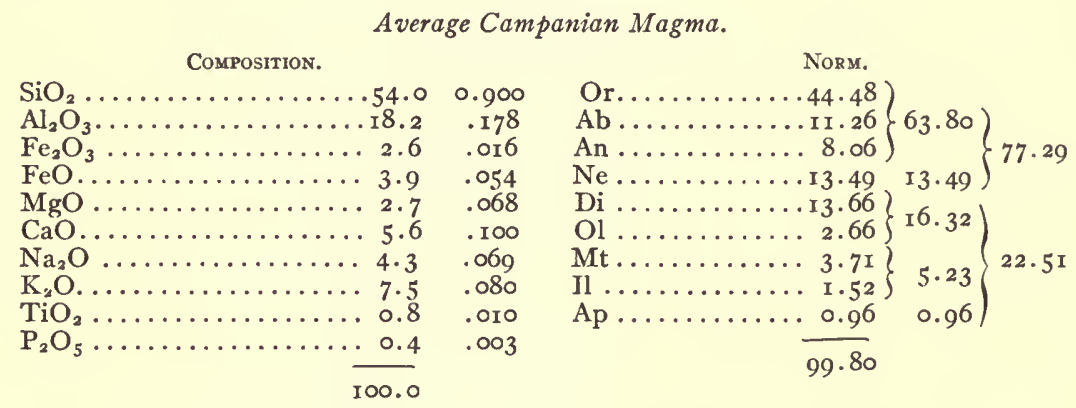

The position of this magma is in borolanose (II. 6. 2. 3). The general resemblance to the average magma of the whole region is very close, both chemically and normatively, the only difference of importance being in the relations of potash to soda, which is here almost unity, potash being only very slightly higher than the soda. This is, of course, due to the peculiar character of the phlegrose rocks of the district, which are so high in soda as to be almost in nordmarkose (I. 5. I. 4).

\section{Time Relations.}

Geologic Age of the Eruptions.

It would lead us too far astray, and would be outside of the province of this paper, to discuss this topic fully and adequately, so a few words must suffice. Furthermore, there exists considerable divergence of opinion in regard to the exact age of the eruptions in some cases.

While the volcanoes of the Tuscan Region date from the Eocene or Miocene Period, those of the Roman Region have begun either in the late Pliocene or in the 
Pleistocene (Quaternary), and in some cases have continued into the present time. There does not seem to be any good evidence in favor of a regular shifting of the volcanic foci along the line in any direction, that is, that the volcanic action began successively later either northwardly or southwardly. On the contrary it is quite clear that some of them have been active simultaneously, or at least that the periods of activity have overlapped.

But there seems to be no doubt of the fact that the extinction of activity has shifted southerly, and that the more northern volcanoes were extinct before the more southern ones. That this extinction was successive in a general way, though possibly with some irregularities, seems also to be true. Thus the Vulsinian volcanoes, which began before those of the Campanian District according to Moderni, the Ciminian and the Sabatinian have all suffered much from erosion, so much so as to have lost much of their original forms. The Latian Volcano seems to have been active in the year 639 B. C. (II4 A. U. C.), if we can believe the story of Livy* as to a shower of ashes from Mount Albanus. The age of the Hernican volcanoes is uncertain, but they were probably extinct before the Latian, as we have no records of an eruption in historic times. There is some evidence going to show that the Auruncan Volcano was active during Roman times, and the date 269 B. C. has been assigned to one eruption. But the evidence is not conclusive, and the general silence on the part of the Latin authors makes one somewhat skeptical as to so recent a date. $\dagger$ The modern activity of Vesuvius is too well known to need more than mention, while the last-recorded eruption of Ischia was in 1302 , and that of the Phlegrean Fields in ${ }_{1538}$ at Monte Nuovo, although the Solfatara Volcano is still emitting hot vapors.

\section{Order of Succession of Types.}

A much more detailed study of the various districts than the writer was able to give and an extensive collation of the literature are needed before this matter can be satisfactorily treated. From such observations as were made, however, and from a general survey of the literature, it would appear that no definite and constant order of succession obtains in the region. Salic types sometimes precede and sometimes follow the more femic ones, those with leucite sometimes underlie and sometimes overlie those without leucite. Instances of both kinds could be cited from the more complex districts, the Vulsinian, Ciminian, Sabatinian, and Auruncan. An order which seems to hold good in general, though with exceptions, in one district is contradicted by the facts of another. Indeed, so varied are the relations in this respect that the only general law which can be laid down for the region, at least for the present, is that there is no definite order of succession.

* Cf. V. Sabatini, Mem. Descr. Carta Geol. Ital., X, 1900, p. 132.

† P. M oderni, Boll. Com. Geol. Ital., 1887, p. 77. 


\section{COMPARISON WITH OTHER REGIONS.}

It is only within the last few years, and following the increase in the number and quality of chemical analyses of igneous rocks, that comagmatic regions (petrographic provinces) have been described in terms that permit of satisfactory correlation between them, with a view to their bearing on the phenomena and processes of differentiation. And even now the number of those which have been at all adequately described is so small that it would be unwise to attempt any broad generalizations. These must wait for the future and a great increase in our detailed knowledge, especially as regards the chemical side, of many widely diverse regions. At the same time it may be profitable, and not without interest, to institute comparisons with one or two others of the best-known regions. The phenomena are so complex that even tentative comparisons may be of use in pointing out some of the lines along which it will be most profitable to work, or in calling attention to certain lacunæ in our knowledge or to features which have been overlooked and which may demand investigation.

From a general survey of the literature it is clear that it is far easier to find well-described regions which differ radically from the Roman than to find those which resemble it. Thus the Christiania Region, so well-known through the classic researches of Brögger, that of Madagascar, recently described by Lacroix, and that of eastern Africa, known through the studies of Prior and others, while they resemble the Roman in the dominantly alkalic character of the rocks, are strikingly dissimilar in that they are dominantly sodic. Most of those around the borders of the Pacific Ocean, those of Great Britain and Iceland, those of Hungary and the Grecian Archipelago are all much more prominently calcic and with soda dominating potash, and in some cases with highly quaric magmas. But it is needless to cite more examples of the dissimilar ones.

In certain respects the Bohemian Region, so ably described by Hibsch, and that of the Eifel and Laacher See, of the rocks of which satisfactory analyses are singularly few, resemble ours. Leucitic rocks are present to some extent and the magmas are for the most part highly alkalic, but here also the soda dominates the potash, giving rise to many highly nephelinic and orthoclase-poor types of rock.

The only sufficiently known region which is strikingly analogous to the Roman one is that of central Montana, the knowledge of which we owe to the labors of Weed and Pirsson, and the general characters of which have recently been summarized by the latter.*

While the geologic occurrence of the rocks of this is very largely intrusive, in the form of laccoliths and stocks with their attendant dikes and comparatively

* L. V. Pirsson, Am. Jour. Sci., XX, 1905, p. 35. 
few flows, the chemical and mineralogical features are very similar, though there are some marked differences.

If the magmatic positions, which express concisely the general chemical characters, of the various analyzed rocks of the Central Montana Region be examined and compared with that on p.II, the main points are clearly seen.

In the first place, there is a considerably greater variety of magmas than in the Roman region, 27 being represented in central Montana against 17 known in central Italy. But the general range is much the same. There are rocks belonging to the persalane, dosalane, and salfemane classes, but none in the dofemane (except one on the border of salfemane) or perfemane classes. While there are some rocks which belong to the quaric orders, britannare and austrare, in the persalane and dosalane classes, the great majority are either perfelic or are more or less lenic, and it is noteworthy that in both regions rocks containing notable amounts of normative lenads are rare in the persalane class, become more frequent in the dosalane, and are most so in the salfemane. Peralkalic rangs are likewise unusual, though more common in the Montana Region than in the Roman, and in the former they are met with in rocks of the dosalane and salfemane classes, which is not the case in the latter. Alkalicalcic rangs are rare in both, and in both also the rangs most commonly met with are domalkalic. In the subrangs the majority of those of the Montana Region are sodipotassic, but with a very considerable representation of dopotassic ones, while we have seen the reverse to be true of the Roman Region, and in addition a few dosodic subrangs are found in Montana sporadically, which are entirely absent in the Italian one.* But on the whole potash can be said to dominate over soda in both, though this is less strongly marked in the Montana rocks. The resemblance between the two regions is also shown among the minor constituents by the prevalence of high $\mathrm{BaO}$ in the rocks of both, a point which will be referred to later.

Similarly, so far as the serial chemical characters are concerned, we find in both a great agreement in that potash increases relatively to soda as silica decreases and as the femic components increase, $\dagger$ and also that magnesia increases over ferrous oxide in the same direction. It will also be noted that in both the general geographical distribution of magmas is much the same. The border or end districts are more highly siliceous and salic and with more soda relatively to potash than the central districts, which are much more distinctly femic and lenic and more markedly dopotassic.

The average magma of the Central Montana Region has not been calculated by Pirsson, but he gives+ an estimate of that of the Highwood District, a comparison of which with the averages of the magma of the Roman Region and of the Campanian District is not without interest.

* It is worthy of note that dosodic subrangs are very common in the Crazy Mountains, which Pirsson does not include in his region. The rocks of these evidently belong to a different and more highly sodic magma.

$\dagger$ Pirsson, op. cit., p. 43.

$\ddagger$ Pirsson, Bull. U. S. Geol. Surv. No. 237,1905 , p. 193. 
Magmas of Roman, Campanian, and Central Montana Regions.

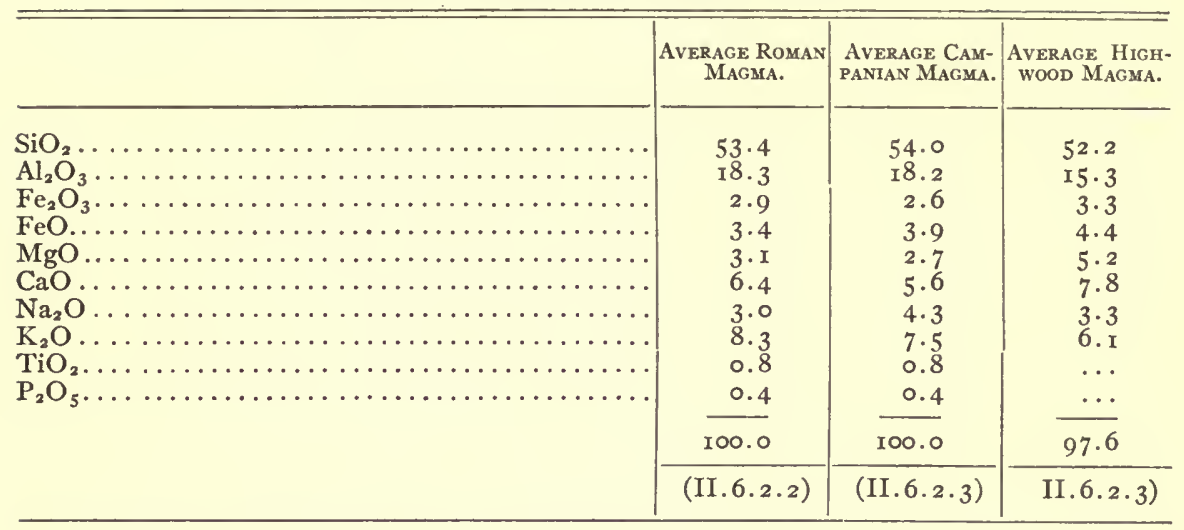

In general features the resemblance between the Italian and the Montana magmas is close, though it must be remembered that in III we are not dealing with the magma of the whole region, but with that of a single district. It is clear that the last is distinctly higher in the femic constituents, the two oxides of iron, magnesia, and lime, and lower in alumina and potash, silica and soda being about the same in both.

Mineralogically also there are some features in common. One of the most striking is the occurrence of many leucite-rich types in both regions, though these are much more abundant in the Roman Region. This is undoubtedly connected with the more potassic character of its magmas, and possibly also with the difference in the geologic occurrences of the rocks. Another is the predominance in both regions of augite as the alferric mineral. The color and other physical properties differ somewhat, it is true, but in both cases this mineral, though titaniferous, does not show the purple tones found elsewhere, and the constant occurrence of a diopside-augite in two comagmatic regions so closely alike magmatically is certainly a very striking fact, and possibly one of some significance.

Again, while biotite is rather more common in the Montana Region, possibly because of the intrusive nature of most of the Montana rocks, it is not an abundant mineral in either, while the hornblendes are rare in both regions. Similarly the alkali-feldspar is invariably a soda-orthoclase, and microcline and microperthitic intergrowths are equally rare in both.

These comparisons could be carried further and with greater detail, but the above must suffice for the present. It shows clearly that, while there are certain constant differences, there is a very great degree of similarity between the two regions, not only in the absolute and serial chemical and the mineralogical characters, but in the distribution in space of the various magmas and rock types.

The bearing of these and similar facts upon the general questions of differentiation, its causes, conditions, and processes, is as yet very obscure. As Pirsson 
has pointed out, these are all undoubtedly complex in most cases, if not in all, especially when differentiation over large areas is involved, and the difficulties in the way of solution of the problems are certainly great. But the discovery of such similarities as have been shown above, and the undoubted occurrence of similarities of a different sort obtaining between similar comagmatic regions of widely distinct characters from the two here discussed, indicate the truth of Pirsson's conclusion that "the distribution and occurrence of igneous rocks are not due to mere chance," and that it is unreasonable "to deny that they are governed like other things in nature by definite laws and processes."

A much larger body of data than is yet available must be collected before we are in a position to ascertain the many facts of differentiation and to understand its laws. This is true even of the smaller and less complex rock-masses, such as dikes and laccoliths, where the chemical and physical factors involved are comparatively simple. It is a fortiori still more true of such large areas and masses as those of comagmatic regions. In these we are confronted with such difficulties in the way of complexities of distribution and structure; complexity, variety, and mass of magmas; the possibility and, indeed, the probability of superposed and diverse processes and conditions; considerations of space and time; the certainty of some known physical factors, as viscosity and convection currents, and the probability of some unknown ones entering into the problem; that we must for the present be content to observe and collect facts, leaving their collation and the final generalizations from them for a future period. 


\section{THE FORMATION OF LEUCITE.}

Although it is now well recognized that a magma of a certain composition may crystallize as very diverse aggregates, the variations depending largely if not entirely upon the conditions obtaining during solidification, it is nevertheless true that the chemical composition of the magma controls the mineral composition of the rock within limits. Without going into a general discussion of this interesting topic, the special case of the relation between the occurrence of leucite in igneous rocks and the composition of the magma may be investigated.

As to the occurrence of this mineral the only general "law" which has yet been recognized is that leucite, as well as nephelite and melilite, are never found in association with quartz,* that is, in rocks with an excess of silica. It is also generally understood that it occurs most frequently in rocks which are rich in potash, but the limitations of this term are very vague, and it is known to occur in rocks whose potash content can not be called high.

For the study of this relation from the side of actual occurrences the Roman Region is especially favorable. The number and variety of its leucitic rocks are great and they have a wide range in chemical composition; both leucitic and nonleucitic rocks occur here of similar as well as of different chemical compositions; and the disturbing factor of differences in physical conditions during solidification is almost entirely eliminated, or at least minimized, by the uniform occurrence of the rocks as effusive lava flows. We may, then, examine the rocks belonging to magmas of the various kinds as to the presence of leucite, drawing such conclusions as we may from these data. The full theoretical discusssion of the problem will be published elsewhere, probably in the Journal of Geology.

\section{The Roman Region.}

Among the persalane rocks of the Roman Region leucite may be said to be non-existent in those which belong to the sodipotassic subrang phlegrose (I. 5. I. 3), though it occurs very sporadically in the blocks of cumal phlegrose at the Vico Volcano. The mineral begins to appear in notable amount in the dopotassic vulsinose rocks (I. 5. 2. 2), many of which are highly leucitic, with the viterboid habit, though the majority of the types of this subrang are non-leucitic. The same is true of the rarer sodipotassic pulaskose (I. 5.2.3) rocks, while in the types belonging to beemerose (I. 6. I. 3), procenose (I. 6. 2. 3), and appianose (I. 7. I. 3) leucite is a constant and important constituent.

In the dosalanes it is, of course, absent from the sorianal harzose (II. 4.3 .3 ), as there is an excess of silica in this magma. The ciminose (II. 5. 2. 2) rocks

* Cf. F. Zirkel, Lehrbuch der Petrographie, Leipzig, I893, I, p. ${ }_{4} 6$. 
resemble those of vulsinose in that some of the types are non-leucitic and some highly leucitic, this mineral assuming the form either of large phenocrysts or of small individuals in the groundmass. In these, as well as in the preceding cases of persalane rocks, it is to be noted that the modal leucite is formed at the expense of normative nephelite, leucite not being found in the norms, except in the tavolatal appianose. In the closely similar but sodipotassic monzonose (II. 5. 2. 3) rocks leucite is not found, except very sporadically in that from L'Arso, while in the few rocks which belong to auruncose (II. 5. 3. 2) leucite is uniformly present in abundance. In the only rocks of this region so far known which belong to shoshonose (II. 5. 3. 3) leucite is wanting.

With the rocks belonging to vicose (II. 6. 2. 2) we meet leucite both in the norm and in the mode, and from here on to the end of the series leucite is a constant and important constituent, no non-leucitic types of vicose (II. 6. 2. 2), braccianose (II. 7. 2. 2), vesuvose (II. 8. 2. 2), or of the salfemane subrangs jugose (III. 7 . 2. 2), fiasconose (III. 7. 3. 2), or albanose (III. 8. 2. 2) being known in the Roman Region.

From these facts we may draw the following conclusions as to the formation of leucite in effusive rocks, in the Roman Region at least: It will not be formed in rocks belonging to quaric orders, or those with an excess of silica (normative quartz). It is not liable to be formed in sodipotassic magmas, especially when of the dosalane class and in persalanes when the norm is perfelic. But this prohibitive influence of the abundance of soda is counteracted by paucity in silica, as in beemerose, procenose, and appianose rocks, whose norms all show notable amounts of lenads.

In magmas which belong to perfelic orders and to dopotassic subrangs, whether in persalane or dosalane, as vulsinose (I. 5. 2. 2) and ciminose (II. 5. 2. 2), leucite may or may not be formed, and these magmas seem to be in a somewhat critical condition as regards the occurrence of this mineral. The occurrences are all extrusive lava flows and no constant differences in the conditions obtaining during solidification can be made out for the leucitic and the non-leucitic flows, nor can any definite order of succession be established. From the chemical side the analyses at hand would lead us to suppose that leucite will not be formed if the silica is above $5^{6}$, assuming that 8 or 9 per cent of potash is present, though it can form with this amount of silica if the potash percentage runs above ro (with about 3 or 4 per cent of soda). Stated in other terms, if no nephelite, or only I or 2 per cent, is found in the norm no leucite or only sporadic crystals will occur in the rock.

In the subrangs of dosalane which show notable amounts of nephelite in the norm and in the similar ones of salfemane, all of these being dopotassic, leucite invariably occurs in the mode.

Although the number of chemical factors possibly involved is large, and the possibilities of mutual readjustments between normative mineral molecules, as between hypersthene and olivine, are therefore complex, it would seem that the 
relations between silica and potash on the one hand, and between potash and soda on the other, are largely the determining factors in the rocks of the region, the conditions of solidification being similar. The data on which to study this question are given in the annexed table, in which the amounts of silica and potash are given both in percentages and as molecular ratios, together with the ratios (molecular) $\frac{\mathrm{SiO}_{2}}{\mathrm{~K}_{2} \mathrm{O}}$ and $\frac{\mathrm{K}_{2} \mathrm{O}}{\mathrm{Na}_{2} \mathrm{O}}$. The rock numbers are the same as in the table of analyses on p. $\mathrm{x}_{4} 6$, and the leucitic rocks are indicated by an asterisk (*), those in which the mineral is merely sporadic and accessory, as the cumal phlegrose and arsal monzonose, being considered non-leucitic.

Relations of Silica, Potash, and Soda in the Roman Rocks.

\begin{tabular}{|c|c|c|c|c|c|c|c|c|c|}
\hline & $\mathrm{SiO}_{2}$ & $\mathrm{~K}_{\mathbf{2}} \mathrm{O}$ & $\frac{\mathrm{SiO}_{2}}{\mathrm{~K}_{2} \mathrm{O}}$ & $\frac{\mathrm{K}_{2} \mathrm{O}}{\mathrm{Na}_{2} \mathrm{O}}$ & & $\mathrm{SiO}_{2}$ & $\mathrm{~K}, \mathrm{O}$ & $\frac{\mathrm{SiO}_{2}}{\mathrm{~K}_{2} \mathrm{O}}$ & $\frac{\mathrm{K}_{2} \mathrm{O}}{\mathrm{Na}_{2} \mathrm{O}}$ \\
\hline I $\ldots \ldots$ & 6 I. 88 & 6.72 & $14 \cdot 5^{2}$ & 0.64 & $23 \ldots \ldots$ & $5^{6.75}$ & $5 \cdot 92$ & 15.02 & 0.83 \\
\hline $2 \ldots \ldots$ & 59.79 & 7.10 & $13 \cdot 12$ & 0.69 & $24 \ldots \ldots$ & $54 \cdot 72$ & 6.87 & I 2.49 & I. 30 \\
\hline $3 \ldots \ldots$ & 60.33 & $7 \cdot 30$ & 12.90 & 0.73 & $25^{*} \ldots$ & 52.37 & $7 \cdot 47$ & $10.9 \mathrm{I}$ & 1.70 \\
\hline $4 \ldots \ldots$ & 59.24 & 9.14 & I0. 17 & I. 23 & $26 * \ldots \ldots$ & 50.86 & 7.15 & II.OI & 2.20 \\
\hline $5 \ldots \ldots$ & 61.62 & 7.60 & I2.68 & 0.87 & $27^{*} \ldots \ldots$ & $5 \mathrm{I} .2 \mathrm{I}$ & 6.60 & 12.20 & I. 75 \\
\hline $6 \ldots \ldots$ & 58.08 & 8.87 & 2.07 & 1.07 & $28 \ldots \ldots$ & 55.69 & $4 \cdot 4 I$ & I9. 74 & 1.00 \\
\hline $7 \ldots \ldots$ & $57 \cdot 5^{8}$ & 8.68 & 10.32 & I. 86 & $29 * \ldots$ & 54.83 & 10.40 & 8.23 & $2 \cdot 3^{6}$ \\
\hline $8 \ldots . \ldots$ & 57.50 & 8.39 & 10. 78 & I. 74 & $30 * \ldots \ldots$ & 51.20 & 10.63 & $7 \cdot 55$ & $3 \cdot 32$ \\
\hline $9 * \ldots \ldots$ & 56.19 & 10.47 & 8.36 & 2.43 & $3 I^{*} \ldots \ldots$ & 50.68 & $9 \cdot 3^{8}$ & 8.45 & $2.3^{8}$ \\
\hline 10*..... & 55.17 & $9 \cdot 5^{8}$ & 9.02 & $2 \cdot 7^{6}$ & $32 * \ldots \ldots$ & $50 \cdot 3^{6}$ & $9 \cdot 39$ & 8.39 & $3 \cdot 13$ \\
\hline I r $\ldots \ldots$ & 57.60 & $8.7 \mathrm{I}$ & 10.02 & I. 63 & $33^{*} \ldots \ldots$ & 50.24 & $7 \cdot 45$ & 10.48 & 2.00 \\
\hline $12 * \ldots \ldots$ & 55.07 & 8.65 & 9.87 & I. 43 & $34^{*} \ldots \ldots$ & 47.65 & $7 \cdot 47$ & 9.90 & I. 78 \\
\hline $13^{*} \ldots \ldots$ & 55.87 & 10.49 & 8.31 & I. 45 & $35^{*} \ldots \ldots$ & 47.89 & 8.23 & 9.18 & 2.08 \\
\hline $14 * \ldots \ldots$ & 50.25 & II. 32 & 6.98 & I. 43 & $36 * \ldots$ & $47 \cdot 20$ & 7.63 & $9 \cdot 7^{2}$ & 2.25 \\
\hline$x_{5} \ldots \ldots$ & $59 \cdot 4 \mathrm{I}$ & 5.29 & I 7.68 & I. 33 & $37^{*} \ldots \ldots$ & 48.10 & 7.90 & 9.55 & I.9I \\
\hline $16 \ldots \ldots$ & $57 \cdot 32$ & 9.15 & 9.84 & I. 87 & $3^{8 *} \ldots \ldots$ & $47 \cdot 7 I$ & 7.64 & $9.8 \mathrm{I}$ & I. 80 \\
\hline $17 \ldots$ & 55.46 & 6.63 & 13.01 & 2.45 & $39 * \ldots \ldots$ & $47 \cdot 39$ & 6.93 & 10. 82 & 3.04 \\
\hline $18 \ldots \ldots$ & $57 \cdot 3 \mathrm{I}$ & $6.3^{8}$ & 10.04 & 3.09 & $40 * \ldots .$. & 44.89 & 3.63 & 19.02 & 2.29 \\
\hline I9*.. & 55.85 & 8.77 & 9.90 & 1.71 & $4 I^{*} \ldots \ldots$ & 46.24 & 6.37 & II.33 & $2.5^{2}$ \\
\hline $20 * \ldots$ & $55 \cdot 2 \mathrm{I}$ & 8.45 & 10. 22 & 1.80 & $42 * \ldots \ldots$ & 46.27 & $8 \cdot 5^{8}$ & 8.47 & 2.07 \\
\hline $2 \mathrm{I} * \ldots$ & $5^{2.14}$ & $7 \cdot 24$ & II. 29 & 2.48 & $43^{*} \ldots \ldots$ & 47.05 & $7 \cdot 5^{2}$ & 9.80 & 3.07 \\
\hline $22 \ldots \ldots$ & $55 \cdot 22$ & $7 \cdot 5^{8}$ & II. 36 & I. 45 & $44^{*} \ldots \ldots$ & 45.99 & 8.97 & 8.00 & $2 \cdot 74$ \\
\hline
\end{tabular}

Regarded thus in tabular form these figures seem to point to no very definite law. While the non-leucitic rocks show generally high $\frac{\mathrm{SiO}_{2}}{\mathrm{~K}_{2} \mathrm{O}}$ ratios, we find almost equally high figures for this (19.74 and 19.02) in the non-leucitic and the leucitic types. Similarly the other ratio, $\frac{\mathrm{K}_{2} \mathrm{O}}{\mathrm{Na}_{2} \mathrm{O}}$, does not show any very marked regularity. But if the figures are plotted as in the subjoined diagram, the abscissæ representing the percentage of silica and the ordinates the ratios in question, some interesting relations are made manifest. The dots represent non-leucitic rocks and the dots in circles leucitic ones. 
In the first place, as regards the amounts of silica alone some very decided breaks in the continuity are visible, as has been mentioned on a previous page. These are especially marked and wide between 48 and 50 per cent, and between 52.5 and 54.6. There are narrower ones between 56.2 and 57.3 (with one analysis in the gap), and between 54.7 and 59.2 , though probably the series of silica percentages between 54.7 and $6 \mathrm{I} .9$ may be regarded as continuous. As the number of analyses is rather large, it would be reasonable to suppose that the two large breaks are real and that they point to some definite differentiation of the general magma into at least three submagmas. It would be of very great interest to discover if similar clusterings, or indications of the presence of submagmas, are to be found in other regions. There are some indications that "such is the case elsewhere, but

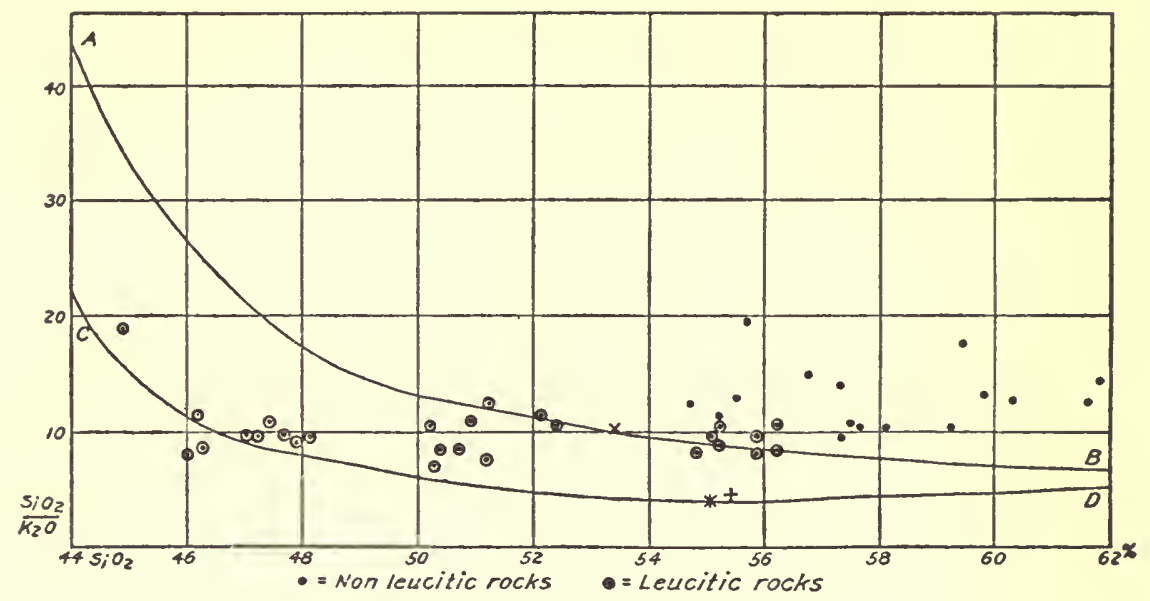

FIG, 2.

this is a matter the investigation of which must be deferred for the present, as it is too general in scope for the purposes of this paper.

Returning to the immediate question at issue, it will be seen that the rocks below 52.5 of silica are uniformly leucitic, while those above 56.3 are as uniformly non-leucitic, and those with silica between 54.6 and 56.3 are of both leucitic and non-leucitic types.

Confining our attention to the rocks with silica above 54.6 , it is clear that the silica-potash ratios of the non-leucitic rocks are uniformly above those of the leucitic ones in the group between 54.6 and 56.3 , which may be called the critical group, and which embraces most of the types of vulsinose and ciminose. To the right of this the silica-potash ratios tend to decrease and even reach the level of or fall below the ratios of the leucitic rocks of the critical group. The division line between them may therefore be regarded as a curve which inclines downward gently to the right, that is, as silica increases, slightly above, but parallel to, the line $A-B$ of 
the diagram, which is drawn from data furnished by a theoretical discussion of the subject and which will be referred to later.

The relations of the potash-soda ratios are not so clear, especially in the critical group, where they are quite involved, those of leucitic and non-leucitic rocks being both above and below each other. But the tendency to high figures as silica decreases and as leucite becomes constant, and to low figures as silica increases and as leucite vanishes, is very marked, and seems to admit of no question.

In regard to the so-called critical magmas, the possibly significant fact may be pointed out that its limits of variation in the percentage of silica are practically conterminous with those shown by the analyses of natural leucites, which are 54.4 and 57.2 in the better analyses.* The best analysis of the leucite of Vesuvius, $\uparrow$ with $\mathrm{SiO}_{2}=55.40$ and $\frac{\mathrm{SiO}_{2}}{\mathrm{~K}_{2} \mathrm{O}}=4.44$, falls just beneath the center of the critical group, while the theoretical leucite molecule, with $\mathrm{SiO}_{2}=55.05$ and $\frac{\mathrm{SiO}_{2}}{\mathrm{~K}_{2} \mathrm{O}}=4.00$, lies a trifle to the left of this. The positions of the two are indicated respectively in the diagram by a small cross $(+)$ and by a star $(*)$. The position of the average magma of the region is indicated by the sign $\times$.

\section{Conclusions.}

From the facts set forth in the preceding pages the following conclusions as to the relation of the magmatic composition to the occurrence of leucite in effusive, holocrystalline, igneous rocks can be drawn. They seem to hold good for the Roman Region, but whether they are of more general application or not must be determined by future investigation. The more special conclusions are first given, followed by those of a more general character.

I. Leucite forms invariably in magmas with $\mathrm{SiO}_{2}$ less than $5^{2} \cdot 5^{0}$ per cent, the ratio $\frac{\mathrm{SiO}_{2}}{\mathrm{~K}_{2} \mathrm{O}}$ being lower than $\mathrm{I}_{3} .0$, though it may be higher than this. (Analytical data are wanting in regard to this last point.)

2. Leucite is invariably absent, or present only very sporadically, when the silica is above 56.5 and with the ratio $\frac{\mathrm{SiO}_{2}}{\mathrm{~K}_{2} \mathrm{O}}$ at least to or higher, the upper limit being infinity. (Analytical data are wanting for ratios considerably lower than ro.)

3. In magmas with silica varying from 54.7 to 56.3 , or those in which the silica percentages are approximately those of the natural leucites, $\frac{\mathrm{SiO}_{2}}{\mathrm{~K}_{2} \mathrm{O}}$ varying from 20 to less than ro, leucite may or may not occur, and these magmas may be regarded as critical ones.

4. In the critical magmas the ratio $\frac{\mathrm{SiO}_{2}}{\mathrm{~K}_{2} \mathrm{O}}$ is uniformly higher, for any given

* Cf. Dana, Mineralogy, 1892, p. 342, and Hintze, Mineralogie, II, I895, p. 13 Ir.

† G. Steiger, analyst, Bull. U. S. Geol. Surv. No. 220, 1903, p. 30. 
silica percentage, in the non-leucitic than in the leucitic rocks, the division line as expressed on the diagram falling slowly as silica increases and rising as silica decreases. It is probable that this division line extends an indefinite distance in both directions beyond the limits of the critical group, but analytical data are wanting to determine this.

5. Leucite is most apt to occur in the mode when the ratio $\frac{\mathrm{K}_{2} \mathrm{O}}{\mathrm{Na}_{2} \mathrm{O}}$ is greater than unity (perpotassic and dopotassic subrangs), the tendency to the formation of leucite being proportional to the ratio; leucite is not apt to be formed if the ratio approximates to unity (sodipotassic subrangs); and leucite does not form when the ratio is less than unity (dosodic and persodic subrangs).

6. The prohibitive tendency of high soda may be overcome by a low ratio of silica to potash.

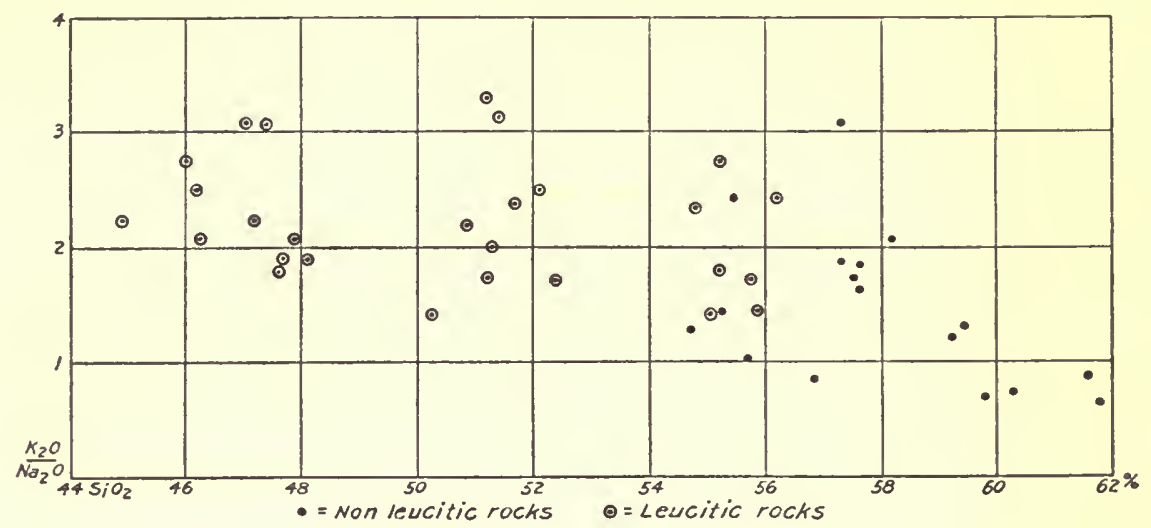

FIG. 3.

The more general conclusions which may be drawn are:

7. The formation of leucite, or its modal occurrence, is directly dependent upon the chemical composition of the magma.

8. The chief chemical factors involved are the percentage of silica, the ratio of silica to potash, and the ratio of potash to soda. The relations of the other constituents are apparently of subordinate importance, if not quite negligible in some cases.

9. The ratio of potash to soda is of subordinate importance to that of silica to potash.

Io. Leucite does not occur in rocks with an excess of silica, or more than sufficient to saturate the bases completely and form the most highly silicated mineral molecules possible, that is, in magmas where quartz would occur in holocrystalline types. 
I I. The presence in the norm of such mineral molecules as nephelite or olivine, which are capable of being more highly silicated, is a necessary condition for the formation of leucite if there is no normative leucite. Of these nephelite seems to be the most important, modal leucite being usually formed by a readjustment of silica involving the formation of modal albite from normative nephelite.

12. When leucite is found in the norm of a rock it is also present in the mode.

I3. It is probable that the formation of leucite anticipates and determines the distribution of other mineral molecules, as those of $\mathrm{Na}_{2} \mathrm{O}$ in albite (as modal plagioclase rather than nephelite, or as $(\mathrm{Fe}, \mathrm{Mg}) \mathrm{O}$ in hypersthene (as modal augite) rather than olivine.

Returning for a moment to the diagram, and anticipating part of a theoretical discussion which will be published elsewhere, it may be pointed out that the line $A-B$ represents the limiting value of the ratio $\frac{\mathrm{SiO}_{2}}{\mathrm{~K}_{2} \mathrm{O}}$ for persalic magmas, in which leucite would be present in the norm (and hence also in the mode according to I 2 above), on the assumption that the affinity of potash for silica is greater than that of soda. For a given silica percentage, if the ratio in question falls below this line the rock will be leucitic. If the ratio is above this line for any given silica percentage the rock may be leucitic actually, but is not necessarily so, the tendency to the formation of leucite in the mode decreasing rapidly as the silica-potash ratio rises above the line.

It appears from this that the so-called "critical group" is, in reality, one of rocks whose silica-potash ratios fall very close to the limiting curve for the formation of leucite, and that the apparently sensitive or nearly balanced chemical condition of their magmas, where very slight changes in the physical or physico-chemical conditions would either bring about or prevent the formation of leucite, is presumably due to this fact.

The line $C-D$ indicates the limiting values in persalic magmas of the possible formation of leucite due to deficient silica. Below it for any given silica percentage there is an insufficient amount of silica for even leucite and nephelite, and hence such magmas would seem to be incapable of existence, unless such a mineral as kaliophilite $\left(\mathrm{K}_{2} \mathrm{O} \cdot \mathrm{Al}_{2} \mathrm{O}_{3} \cdot 2 \mathrm{SiO}_{2}\right)$, were present. It is interesting to note that the only two analyses which fall below it here are Nos. 42 and 44 on page I46, the rocks corresponding to which contain notable amounts of akermanite in the norm, and of modal melilite in one case at least. 


\section{THE DISTRIBUTION OF BARIUM.}

In the comparison of the Roman and Central Montana Regions it was noted that the rocks of both regions are characterized by the presence of large amounts of barium, large, that is, for this constituent, the amount of which in igneous rocks is very seldom over I per cent and usually less than one-tenth of this. It will be appropriate, therefore, in this connection to discuss briefly the distribution of barium among igneous rocks.

Hillebrand* and Vogt $†$ have called attention to its widespread occurrence, and the former has pointed out* the local variation of the igneous rocks of the United States in regard to this constituent, in that those "of the Rocky Mountain region show far higher average percentages than the rocks from the eastern and more western portions." It will be of interest to examine its distribution from another point of view, not so much that of the locality as in relation to the other chemical characters of the magmas or comagmatic regions.

Our data for such a discussion are unfortunately somewhat scanty. In the igneous rocks of the United States $\mathrm{BaO}$ has been determined very frequently by the chemists of the Geological Survey, especially in the more recent analyses, where it is invariably looked for. It is also regularly determined by the chemists of the Geological Survey of New South Wales, and has been determined frequently in the rocks of British Guiana by Professor J. B. Harrison. For the igneous rocks of Europe, as well as of Asia and Africa, determinations of $\mathrm{BaO}$ are almost nonexistent, those presented in this paper being about the only ones to be found. Indeed $\mathrm{BaO}$, as well as most of the other minor constituents, have been usually neglected in rock analysis. Outside of the main constituents, $\mathrm{TiO}_{2}, \mathrm{P}_{2} \mathrm{O}_{5}$ and $\mathrm{MnO}$ are the only minor ones to which attention is commonly paid.

The average percentage of barium in the earth's crust was first estimated by Clarke $\$$ in I89I, the figure, 0.03 per cent, being based only on analyses of rocks of the United States. This was later and successively $\|$ raised to $0.04,0.05$, and 0.089 ; these figures applying only to the igneous rocks of the United States. The reason for the great difference between the earlier estimates and the latest is the difference in method of computing the means. In the earlier estimates all the analyses were averaged as if each was complete, while in the last the determinations for each constituent were averaged separately. $\mathrm{As} \mathrm{BaO}$ was not determined in many of the analyses, this would lead to low figures by the former method.

* W. F. Hillebrand, Jour. Am. Chem. Soc., XVI, 1894, p. 8r.

$\dagger$ J. H. L. Vogt, Zeils. prakt. Geol., 1898, p. 23 x.

$\ddagger$ W. F. Hillebrand, Bull. U. S. Geol. Surv. No. 148,1897 , p. 19.

§ F. W. Clarke, Bull. U. S. Geol. Surv. No. 78, 1891, p. 39.

|| Clarke, Bulls. U. S. Geol. Surv. No. 148, 1897. p. 13; No. 168, 1900, p. 15; No. 228, 1904, p.19.

I Clarke. Bull. U. S. Geol. Surv. No. 228, 1904, p. 16. 
Assuming that the value of $0.1 \mathrm{I}$ for $\mathrm{BaO}$ in the igneous rocks of the United States is correct, it must be noted that the data include many analyses of rocks from regions where this constituent is prominent, and to judge from the meager indications at hand for other parts of the globe, it would seem that the average for the earth as a whole is considerably lower than this. Exactly how much less it is impossible to say, but it is probable that the average percentage of barium in the igneous rocks of the globe may be put at about 0.05 , equivalent to about 0.06 of $\mathrm{BaO}$. While this figure is based on admittedly insufficient data, it is probably not far from truth, and may be accepted provisionally for the present. For Europe, at least, it is undoubtedly less than for the United States.

Examining analyses in which $\mathrm{BaO}$ has been determined, those of the United States, New South Wales, British Guiana, and the Roman Region, it is found that this constituent tends to increase as silica decreases, though this is not marked, and seems to be subordinate to other relations. These are that rocks high in $\mathrm{BaO}$ are likewise apt to be high in $\mathrm{K}_{2} \mathrm{O}$, especially if considerable $\mathrm{CaO}$ is also present. On the other hand, rocks high in $\mathrm{Na}_{2} \mathrm{O}$, and those which are docalcic or percalcic (that is with very subordinate amounts of the alkalis) show very small amounts of $\mathrm{BaO}$ as a rule.

All the specific data can not, of course, be cited here, but the following illustrations may be given. In the rocks of the Leucite Hills in Wyoming, which are the richest in potash as well as in barium so far known, with an average percentage of I0.53 for $\mathrm{K}_{2} \mathrm{O}, \mathrm{BaO}$ is 0.80 , in the Central Montana Region the average for $\mathrm{K}_{2} \mathrm{O}$ is 4.75 and that of $\mathrm{BaO}$ is 0.33 , while in the Roman Region the figures are respectively 7.93 and 0.I6. The average percentage of $\mathrm{K}_{2} \mathrm{O}$ in central Montana may not seem very high, but it is very considerably above that for the igneous rocks of the United States, 2.93,* or for the earth, 3.r6. $\dagger$ That for the Roman Region is much above this, and relatively high potash is also shown by the frequent occurrence of leucite rocks in both regions. While the figure for $\mathrm{BaO}$ in the Roman Region may seem low, it is above the average one as stated above, and certainly above that for European rocks so far as the data at hand allow us to judge.

Examples of the converse of the above among the rocks of the United States are so numerous that it is needless to cite instances. An examination of the analyses recorded in the bulletins mentioned above will disclose the frequency of figures for $\mathrm{BaO}$ varying from o.ro to none in the rocks of comagmatic regions where leucitic rocks do not occur, and where $\mathrm{Na}_{2} \mathrm{O}$ is the dominant alkali or where salic lime dominates over the alkalis. Similarly in British Guiana the analyses of Professor Harrison show an average percentage for $\mathrm{K}_{2} \mathrm{O}$ of 2.47 , while that of $\mathrm{BaO}$ is about 0.02 , and this latter constituent is reported as absent in half the analyses.

The igneous rocks of New South Wales furnish somewhat different results. Here 46 excellent analyses published between I902 and r905 in the records of the

* Clarke, Bull. U. S. Geol. Surv. No. 228, 1904, p. I9.

† Washington, Prof. Paper U. S. Geol. Surv. No. 14, 1903, p. 107. 
Geological Survey show an average for $\mathrm{K}_{2} \mathrm{O}$ of $2.6 \mathrm{r}$, that for $\mathrm{BaO}$ being 0.094 . This figure for $\mathrm{K}_{2} \mathrm{O}$ is distinctly below the average for igneous rocks as a whole, while that for $\mathrm{BaO}$ is somewhat above the average already given. Also the rocks of the country, so far as known, are relatively high in soda, dosodic and sodipotassic subrangs predominating, and nephelite being quite common. But it is notable that the highest figures for $\mathrm{K}_{2} \mathrm{O}, 0.32$ and 0.30 , are reported for the "leucite-basalts" of Byerock and El Capitan, and that in the "olivine-basalts" and "monchiquites" the percentages of $\mathrm{BaO}$ are expressed in a few hundredths of I per cent.

In greater detail it will be found that for any region the variation of $\mathrm{BaO}$ corresponds in a general way with that of $\mathrm{K}_{2} \mathrm{O}$, though there are exceptions to this in all. From the facts above we may infer, at least provisionally and with due recognition of the insufficiency of our data, that there is some correspondence between the $\mathrm{K}_{2} \mathrm{O}$ and the $\mathrm{BaO}$ in igneous rocks, and that the two go hand in hand more or less, the detailed relations varying with the special characters of the region.

But while such a general correspondence is thus indicated, it can not be denied that there are exceptions and that there does not seem to be any strict proportionality between the amounts of the two constituents, at any rate when different regions are considered. This is illustrated by the figures for the Roman and the Central Montana Regions, and among the analyses of the rocks of the United States, New South Wales, and the Roman Region cases can be found with quite high figures for $\mathrm{BaO}$, connected with relatively low ones for $\mathrm{K}_{2} \mathrm{O}$.

It would seem, therefore, that the distribution of $\mathrm{BaO}$, while almost certainly connected in some way with that of $\mathrm{K}_{2} \mathrm{O}$, is dependent also upon more general magmatic or regional characters. It is uncertain as yet whether the correspondence between the two, assuming this to exist, is due to some relation between potassium and barium as elements, to the similarity of their behavior in regard to the physico-chemical processes involved in the formation or differentiation of igneous rocks, or finally to a mere coincidence, the correspondence being brought about by chance segregations in the earlier stages of the formation of igneous magmas in the body of the earth.

The present case seems to be analogous to the predilection of $\mathrm{ZrO}_{2}$ for sodic rocks and that of $\mathrm{Cr}_{2} \mathrm{O}_{3}$ for those high in magnesia. Exceptions to both of these are known, in the sense that highly sodic rocks are found with little or no $\mathrm{ZrO}_{2}$ and highly magnesic ones in which $\mathrm{Cr}_{2} \mathrm{O}_{3}$ is absent. But the general correspondence between these pairs of constituents, as well as between others which might be mentioned, is now generally recognized in petrology.

In view of the common and widespread occurrence of such correspondences, the exceptions should not be held to invalidate the final conclusions as to the distributions. They indicate rather that the relations are more complex than is now apparent, and that the distributions of the rarer elements, as well as of the more common ones, among igneous magmas or rocks are the resultants of many factors. 
Whatever be the true facts it is clear that such problems are of considerable importance, not only to petrology but to other sciences as well, and that for their solution complete chemical analyses of igneous rocks and the determination of constituents which are usually disregarded on account of their rarity are absolutely essential.

As to the minerals into which the $\mathrm{BaO}$ enters in igneous rocks, the data are as yet unsatisfactory, since many mineral analyses have suffered, like those of rocks, from neglect to determine the rarer constituents. As shown by the analyses in Hintze's Mineralogie, by those in Bulletin No. 220 of the U. S. Geological Survey (I903), and as pointed out by Vogt in the paper cited above, $\mathrm{BaO}$ has been found in many feldspars, though it has been looked for only exceptionally. It would seem to be most common in orthoclase, soda-orthoclase, and microcline, presumably as the hyalophane molecule, and has also been noted in a few soda-lime feldspars, where it doubtless exists in the molecule of celsian. Its presence has been detected in both muscovite and biotite, sometimes in very considerable amount, up to as high as 6.84 of $\mathrm{BaO}$, while it seems to be absent from, or present only as traces in, the pyroxenes and amphiboles. It will be noted that these facts of distribution among minerals, showing that $\mathrm{BaO}$ is most prominent in the potassic minerals and least so in those poor in potash, are in line with the observations as to the distribution of $\mathrm{BaO}$ among igneous rocks.

There does not seem to be any record of the presence of $\mathrm{BaO}$ in leucite, at least none has been found in a search of the literature. A large leucite from the viterbal vicose of Garofali in the Auruncan District was examined, and furnished 0.09 per cent of $\mathrm{BaO}$, while the similar rock from Monte San Antonio gave 0.33 per cent. It is expected to examine other leucites in this regard, but it would seem from this result that the $\mathrm{BaO}$ in the Italian rocks exists, for the most part, in the feldspars, and only subordinately in the leucite. 


\section{BIBLIOGRAPHY.}

The following list does not aim at completeness, but simply presents the books and papers, especially those of more modern dates, which have been found most useful in the present study. It includes chiefly those in which the several districts and their igneous rocks have been described petrographically, but only very few which deal chiefly or solely with the structural and stratigraphical geology. The districts vary widely from a bibliographical point of view. In some cases, notably the Campanian and Latian Districts, the literature is extensive and covers several centuries, while for others the literature is scanty and the number of titles few.

I. Авгсн, H. Geologische Beobachtungen über dievulkanischen Erscheinungen und Bildungen in Unter- und Mittel-Italien. Braunschweig, r84 I, I, Lief. r, pp. I-I34.

2. Branco, W. "Die Vulkane des Herniker-Landes bei Frosinone in Mittel-Italien." Neu. Jahrb., 1877 , pp. $561-589$. (Map.)

3. Branco, W. "I Vulcani degli Ernici nella Valle del Sacco." Atti Acc. Linc. (3), I, I877, pp. 80 I-8I 7 .

4. Bucca, L. "Contribuzione allo studio petrografico dell' Agro Sabatino e Cerite." Boll. Com. Geol. Ital., I 886 , pp. 2 I I-223.

5. Bucca, L. "Il Monte di Roccamonfina." Boll. Com. Geol. Ital., 1886, pp. 245-265.

6. BuccA, L. "Contribuzione allo studio petrografico dei Vulcani Viterbesi." Boll. Com. Geol. Ital., r888, pp. 57-63.

7. BuccA, L. "Studio petrografico sulle trachite leucitiche del Lago di Bolsena." Riv. Min. Crist., XII, I893, pp. I8-30.

8. Deecke, W. "Fossa Lupara, ein Krater in den phlegräischen Feldern bei Neapel." Zeits. d. deutsch. geol. Ges., XL, r888, pp. r66-r8r.

9. DeEcke, W. "Bemerkungen zur Entstehungsgeschichte und Gesteinskunde der Monti Cimini." Neu. Jahrb., B. B. VI, I889, pp. 205-240.

Io. Deecke, W. Geologischer Führer durch Campanien. Berlin, Igor, pp. 235 .

I I. Dell' Erba, L. "Considerazioni sulla genesi del Piperno." Giorn. Min. Pet., III, I892, pp. $23-53$.

12. DE Lorenzo and Rrva. "Il cratere del Vivara nelle Isole Flegree." Mem. Acc. Napoli, $\mathrm{X}$, I900, No. 8, pp. I-60.

I3. De Lorenzo and Riva. "Il cratere di Astroni nei Campi Flegrei." Mem. Acc. Napoli, $\mathrm{XI}, \mathrm{I902}, \mathrm{No} .8$, pp. I -87 .

14. De Lorenzo, G. "I crateri di Miseno." Mem. Acc. Napoli, XIII, I905, pp. I-25.

15. De Stefani, C. “I Vulcani Spenti dell' Apennino settentrionale." Boll. Soc. Geol. Ital., $\mathrm{X}$, I89r, pp. 499-555.

I6. FANTAPpIE, L. “Sui Proietti vulcanici trovati nell' Altipiano tufaceo occidentale dei Vulsinii." Mem. Acc. Linc. (5), II, I898, pp. 547-575.

17. Fuchs, C. W. C. "Die Laven von Vesuv." Neu. Jahrb., I866, pp. 667-687; r868, pp. $553-562 ;$ r 869 , pp. 42-59, r69-r93.

18. Fuchs, C. W. C. "Die Insel Ischia." Tsch. min. Mitth., 1872, pp. 196-239.

I9. Fuchs, C. W. C. "Monografia geologica dell' Isola d' Ischia." Mem. Com. Geol. Ital., II, I873, pp. I-58. (Map.) 
20. GÜNrher, R. T. “The Phlegräan Fields.” Geog. Jour., London, 1897, pp. 412-435, 477-499. (Maps.)

2 I. Haughton, S. "Report on the Chemical, Mineralogical, and Microscopical Character of the Lavas of Vesuvius from I63I to I868." Trans. Irish Acad., XXVI, I876, pp. 49-I64.

22. Johnston-Lavis, H. J. "The Geology of Monte Somma and Vesuvius, being a Study of Vulcanology." Quart. Jour. Geol. Soc., XL, 1884, pp. 35-1 I 2.

23. Johnston-Lavis, H. J. "On a Remarkable Sodalite Trachyte Lately Discovered in Naples, Italy." Geol. Mag., Dec. III, VI, x889, pp. 74-77.

24. Johnston-Lavis, H. J., and others. The South Italian .Volcanoes. Naples, r89r, pp. 33 r.

25. Kalkowsky, E. "Ueber den Piperno." Zeits. d. deutsch. geol. Ges., XXX, 1878, pp. 663-677.

26. KLEIN, C. "Petrographische Untersuchung einer Suite von Gesteine aus der Umgebung des Bolsener Sees." Sb. Ak. Wiss., Berlin, I888, pp. 9I-I2I; also Neu. Jahrb., B. B. VI, I889, pp. I-35.

27. Mercalli, G. "Osservazioni petrografico-geologiche sui Vulcani Cimini." Rend. Inst. Lomb., XXII, ז889, pp. I-9.

28. Mercalli, G. "Contribuzione allo studio geologico dei Vulcani Viterbesi." Mem. Acc. Linc., XX, I903, pp. 5-38.

29. Moderni, P. "Note geologiche sul gruppo vulcanico di Roccamonfina." Boll. Com. Geol. Ital., I887, pp. 74-99. (Map.)

3o. Moderni, P. "Le bocche eruttive dei Vulcani Sabatini." Boll. Com. Geol. Ital., i896, pp. 57-I 12, I 29-ז60. (Map.)

3r. Moderni, P. Contribuzione allo studio geologico dei Vulcani Vulsini. Roma, I904, pp. 234. (Map.)

32. RICcIARDI, L. "Ricerche di chimica vulcanologica sulle rocce dei Vulcani Vulsinii." Gazz. Chim. Ital., XVIII, I888, pp. I-2 I.

33. Ricciardi, L. "Ricerche chimiche sulle rocce vulcaniche dei dintorni di Viterbo." Atti Soc. Ital. Sci. Milano, XXVIII, 1885.

34. Roth, J. Der Vesuv und die Umgebung von Neapel. Berlin, I857, pp. 539 .

35. Sabatini, V. "Sulla origine del felspato nelle leucititi Laziali." Boll. Soc. Geol. Ital., XV, I896, pp. $70-76$.

36. Sabatini, V. "Vulcano Laziale." Mem. Carta Geol. Ital., X, igoo, pp. 392. (Map.)

37. Sabatini, V. "De l'état actuel des recherches sur les volcans de l'Italie centrale." C. $r$. VIII. Cong. Géol. Int., Paris, rgor, I, pp. 366-376.

38. Sabatini, V. "Il peperino de' Monti Cimini." Boll. Com. Geol. Ital., rgo2, pp. I-r2.

39. Sabatrni, V. De l'état actuel des recherches sur les volcans de l'Italie centrale. C. r. IX. Cong. Géol. Int., Vienne, I904, pp. 663-679. (Map.)

40. Speciale, S. "Ricerche chimiche sulle lave degli Ernici." Boll. Com. Geol. Ital., I879, pp. 301-302.

4I. Struever, G. "Studi petrografici sul Lazio." Mem. Acc. Linc. (3), I, I877, pp. I-I5.

42. Struever, G. "Contribuzione alla mineralogia dei Vulcani Sabatini." Mem. Acc. Linc. (4), I, ז885, pp. I-I7.

43. Titronı, T. "La regione trachitica dell' Agro Sabatino e Cerite." Boll. Soc. Geol. Ital., IV, I 885 , pp. $337-376$.

44. VERRI, A. "I Vulcani Cimini." Atti Acc. Linc., VIII, I880, pp. 3-34. (Map.)

45. VERRI, A. "Osservazioni geologiche sui Crateri Vulsinii." Boll. Soc. Geol. Ital., VII, I888, pp. $49-99$.

46. VerRI, A. "Note per la storia del Vulcano Laziale." Boll. Soc. Geol. Ital., XII, I893, pp. 39-80 and XIII, r 894 , pp. 559-585.

47. Vrola, C. "Osservazioni geologiche fatte nella Valle del Sacco in Provincia di Roma, e studio petrografico di alcune rocce." Boll. Com. Geol. Ital., I8g6, pp. 4-35. (Map.) 
48. Viola, C. "Mineralogische und petrographische Mittheilungen aus dem Hernikerlande in der Provinz Rom (Italien)." Neu. Jahrb., I899, I, pp. 93-I37.

49. Vom Rath, G. "Das Albaner-Gebirge." Zeits. d. deutsch. geol. Ges., XVIII, 1866, pp. 5 I0-56r.

50. Vom Rath, G. "Die Gegend von Bracciano und Viterbo." Zeits. d. deutsch. geol. Ges., XVIII, I866, pp. 56I-585.

51. Vom Rath, G. "Monte di Cuma, Ischia, Pianura." Zeits. d. deutsch. geol. Ges., XVIII, I866, pp. 607-639.

52. Vom RatH, G. "Die Umgebungen des Bolsener Sees." Zeits. d. deutsch. geol. Ges., XX, I868, pp. $26_{5}-307$.

53. Vom Rath, G. "Zwei Gesteine der Rocca Monfina." Zeits. d. deutsch. geol. Ges., XXV, I873, pp. $243^{-247}$.

54. Washington, H. S. "On Some Ischian Trachytes." Am. Jour. Sci., I, I896, pp. $375-385$.

55. Washington, H. S. "Italian Petrological Sketches: I, The Bolsena Region." Jour. Geol., IV, I 896 , pp. $54 \mathrm{I}-566$.

56. Washington, H. S. "Italian Petrological Sketches: II, The Viterbo Region." Jour. Geol., IV, I896, pp. 826-849.

57. Washington, H. S. "Italian Petrological Sketches: III, The Bracciano, Cerveteri, and Tolfa Regions." Jour. Geol., V, 1897, pp. 34-49.

58. Washington, H. S. "Italian Petrological Sketches: IV, The Rocca Monfina Region." Jour. Geol., V, I897, pp. 24I-256.

59. Washington, H. S. "Italian Petrological Sketches: V, Summary and Conclusions." Jour. Geol., V, I897, pp. 349-377.

6o. Washington, H. S. "Some Analyses of Italian Volcanic Rocks." Am. Jour. Sci., VIII, I 899, pp. 286-294.

6r. Washington, H. S. "Some Analyses of Italian Volcanic Rocks, II." Am. Jour. Sci., IX, I900, pp. 44-54.

62. Wrlliams, J. F. "Ueber den Monte Amiata in Toscana und seine Gesteine." Neu. Jahrb.,

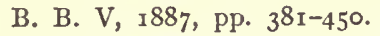

To these may be added the following general works which contain descriptions of some types.

63. LAcrorx, A. Les enclaves des roches volcaniques. Mâcon, I893.

64. Rosenbusch, H. Mikroskopische Physiographie der massigen Gesteine. Stuttgart, I 896.

65. Rotн, J. Allgemeine und chemische Geologie. Berlin, I883.

66. Zirkel, F. Lehrbuch der Petrographie. Leipzig, I894. 


\section{INDEX.}

Absolute chemical characters............. 148

Abundance of subrangs................ 172

Acquapendente..................4, 45,49

Age of eruptions.................... 175

Alban Hills. Seo Latian District.

Albanose:

Analysis of.

.131, 135, 139, 147

Description of $130,132,133,138,140$

Occurrence of ............152, 137, 140, 161, 164 Albanose-jugose :

Analysis of ......................124, 147

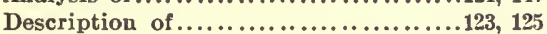

Occurrence of ........................ 125

Amiatose..........................162, 170

Analyses :

Albanose.....................131, 135, 139, 147

Albanose-jugose....................124, 147

Andesite ............................ 88

Appianose ......................51, 147

Augite............................... 134

Augite-trachyte...................20, 147

Auruncose....................80, 83, 86, 147

Beemerose......................47, 147

Biotite-latite ...................56, 88, 147

Biotite-vulsinite ..................88, 147

Braccianose ...........104, 109, 113, 116, 118, 147

Cascadose .......................... 127

Cecilite .............................. 139

Ciminite......................63, 75, 147

Ciminose.................59, 63, 67, 72, 147

Ciminose-auruncose...............80, 83, 147

Ciminose-monzonose ................83, 147

Fiasconose......................127, 147

Foyaite ............................. 51

Gauteite ......................... 75

Hattynitic leucite-tephrite............51, 147

Janeirose-appianose................51, 147

Jugose............................124, 147

Latite ......................56, 88, 147

Leucito-basalt........................ 135

Leucite-basanite...................127, 147

Leucite-phonolite ...............47, 147

Leucite-tephrite'. .43, 51, 72, 80, 86, 92, 97, 101,

$104,109,113,116,117,118,147$

Leucite-tinguaite..................... 51

Leucite-trachyte..........36, 43, 67, 83, 92, 147

Leucitite..........109, 113, 124, 131, 135, 139, 147

Melilitic lencitite..................139, 147

Minette ............................. 127

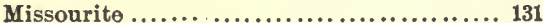

Monzonose .........................75, 147

Nephelite-syenite..................47, 51

Nordmarkose-phlegrose............20, 23, 147

Obsidian .........................28, 147

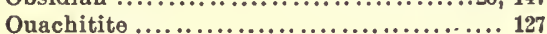

Analyses:

Peperiuo .........................56, 147

Phlegrose...................20, 23, 28, 147

Procenose-pulaskose.................43, 147

Pulaskose.........................43, 147

Shoshonose........................88, 147

Table of........................... 147

Tavolatite........................51, 147

Trachydolerite....................75, 147

Trachyte.....20, 23, 28, 31, 36, 43, 59, 63, 75, 147

Trachyte-obsidian .................28, 147

Vesuvose............................... 122

Vesuvose-braccianose.................118, 147

Vicose.......................92, 97, 101, 147

Vicose-ciminose....................72, 147

Vulsinite.........................31, 36, 147

Vulsinose...............31, 36, 43, 59, 75, 147

Vulsinose-ciminose .................59, 147

Vulsinose-pulaskose................43, 147

Andesite, analysis of . ................. 88

Anguillara .........................6, 132

Appianose:

Analysis of...................... 147

Description of ......................50, 54

Occurrence of ......................53, 164

Appian Way........................51, 53

Apulian Region....................... 1

Arcioni .............................113, 114

Arsal monzonose:

Analysis of .....................75, 147

Description of $\ldots \ldots \ldots \ldots \ldots \ldots \ldots \ldots \ldots \ldots, 78$

Arsal vulsinose-ciminose:

Analysis of . . . . . . . . . . . . . . . . 147

Description of ....................58, 62

Arso................ $8,74,75,76,77,78,157$

Aspenal monzonose, analysis of........... 75

Astroni Volcano......31, 33, 42, 43, 44, 75, 78, 157

Atrial braccianose :

Analysis of ....................116, 147

Description of ....................115, 117

Atrio del Cavallo................... 116

Augite:

Analysis of........................ 134

Occurrence of ........................ 157

Augite-trachyte:

Analysis of. .......................20, 147

Description of ..................... 19

Auruncan District..2, 7, 21, 26, 29, 33, 36, 40,

$61,84,88,90,92,94,110,122,164,167$

Auruncose :

Analysis of ..................80, 83, 86, 147

Description of..............79, 82, 84, 85, 87

Occurrence of..............81, 84, 87, 161, 165

Average Magma................167, 174, 175, 179 


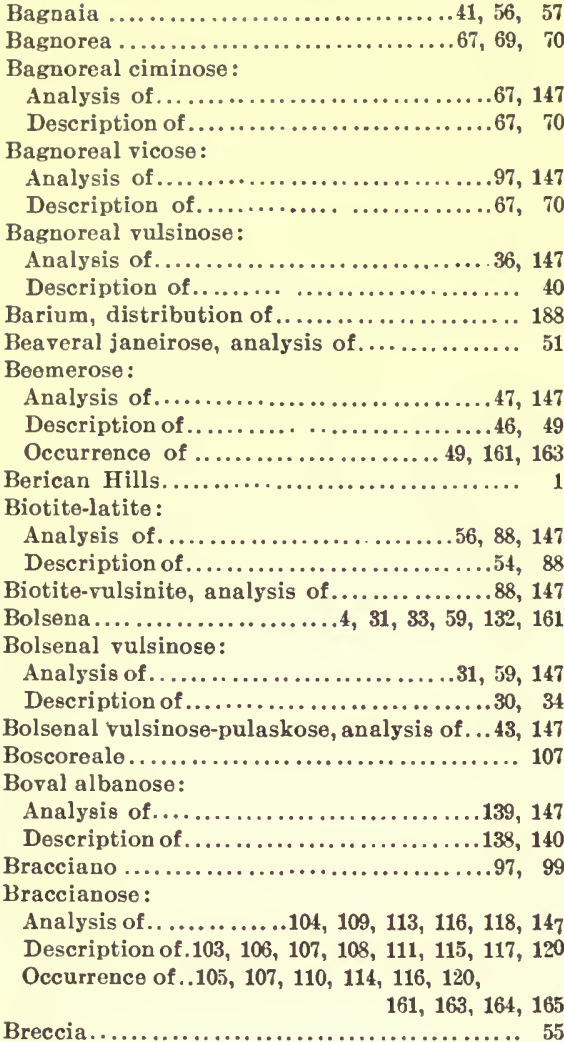

Campanian District..2, 8, 21, 26, 75, 78, 104, $105,116,118,120,165,166,167$

Campiglia ............................... 1

Capo di Bore.........................139, 140

Capodimonte ............................. 4

Capranica .............................. 41

Caprara................................... 31

Carbone.................................. 21

Casa Fredda............................. 21

Casi .................................26, 33

Cavorcie ............................41, 65

Ceccanal fiasconose..................... 129

Ceccano.................................. 129

Cecilite:

Analysis of ........................139, 147

Description of ......................... 138

Cellal venanzose.......................... 159

Cerveteri.............................. 1

Ciminian District.... 1, 5, 26, 29, 36, 39, 41, $56,57,59,61,63,65,67,70,72,73,75$,

$78,81,92,94,162,166,167$
Ciminite :

Analysis of .......................63, 75, 147

Description of.....................62, 74

Ciminose :

Analysis of ................59,63, 67, 72, 147

Description of..........58,62,66, 67, 70,71, 73

Occurrence of.....61, 66, 70,73, 161, 162, 163, 165

Cimino Volcano.......5, 57, 61, 63, 65, 66, 162, 163

Classification of rocks................... 11

Clathrate texture......................... 109

Colonetta ..........................63, 65

Comagmatic region, use of term............

Copper, presence of....................135, 149

Correlation of types....................... 141

Cremate............................... 78

Croce di San Martino...................... 81

Crocicchie ........................109, 110, 113

Cuma..........................23, 24, 29

Cumal phlegrose:

Analysis of .........................23, 147

Description of......................22, 27

Dellenose ............................... 170

Dikes, rarity of........................ 144

Epomeo Volcano............................ 8

Euganean Hills........................ 1

Fedorovite, analysis of ................... 134

Feldspar, origin of, in leucitite........... 112

Fiasconose:

Analysis of.......................127, 147

Description of .......................126, 129

Occurrence of.....................128, 161, 164

Fiescolal ciminose:

Analysis of ........................63, 147

Description of .....................62, 66

Fiordinal fiasconose:

Analysis of.... ....................127, 147

Description of ..........................126, 129

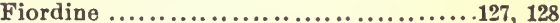

Flow breccia......................... 55

Foglianal ciminose-aurancose:

Analysis of ..........................80, 147

Description of......................79, 82

Foglianal vicose:

Analysis of ..........................92, 147

Description of........................91, 95

Fontana Fiescoli........................ 63

Formal descriptions, discussion of .............. 15

Fosso della Parchetta ...................72, 73

Foyaite, analysis of ...................... 51

Frascati ................................ 192

Frosinone .......................114, 135, 137

Galeral albanose-jugose :

Analysis of ..........................124, 147

Description of.....................123, 125

Galeral braccianose:

Analysis of ........................109, 147

Description of .......................108, 111

Galeroid habit ........................ 109

Gauteite, analysis of .................... 75

Glass, occurrence of .................... 160 
Gradoli.

Grads, use of discussed.....

Granatello............................... 120 Grignano ...................35, 36, 38, 39, 92 Grotta Ferrata...................114, 132, 140

Halite, use of, in the norm ................ 15

Harzose:

Analysis of............................56, 147

Description of......................54, 58

Occurrence of ............................57, 162

Hañnitic leucite-tephrite............... 51

Hernical braccianose:

Analysis of ........................113, 147

Description of ......................111, 115

Hernican District...2, 7, 112, 113, 114, 129, $135,137,164,167$

Highwood Mountains................75, 127, 131

Homologous types.......................... 142

Hornblende, rarity of.................. 159

Ischia.......8, 19, 20, 21, 26, 27, 28, 29, 75, 78, 165

Ischial nordmarkose-phlegrose:

Analysis of...........................20, 147

Description of......................19, 21

Janeirose-appianose:

Analysis of ...........................51, 147

Description of.....................5, 54

Jugose :

Analysis of .........................124, 147

Description of.......................123, 125

Occurrence of...................125, 161, 165

Lagosello ............................94, 122 Lake Bolsena.......3, 99, 102, 110, 122, 131. 132, 161 Lake Bracciano .. .6, 47, 49, 94, 109, 110, 132, 137, 163

Lake Mezzano ............................ 4

Lake Vico ......................... $70,75,78$

L'Arso...................8, 74, 75, 76, 77, 78

La Scala...........................118, 120

Latera Volcano....................4, 45, 49, 161

Latian District...2, 6, 51, 53, 110, 112, 113,

$114,132,139,140,164,167$

Latite:

Analysis of ......................... $56,88,147$

Leucite, formation of .................. 181

Leucite-basanite :

Analysis of .......................127, 147

Description of .......................... 126

Leucite-phonolite :

Analysis of .......................47, 83, 147

Description of .......................46, 49

Use of term............................ 13

Lencite-tephrite:

Analysis of..43, 51, 72, 80, 87, 92, 97, 101, $104,107,113,116,147$

Description of...50, 54, 71, 79, 86, 92, 96, $100,103,115$

Lencite-tinguaite, analysis of............. 51 Leucite-trachyte:

Analysis of.......

$.36,43,67,83,92,147$

Description of $34,40,41,67,82$
Leucitite:

Analysis of....109, 113, 122, 124, 131, 135, 138, 147

Description of .........108, 111, 121, 123, 130, 133

Madonna della Quercia ..................... 65

Madonna del Riposo......................97. 99

Madonna d'Oro.........................114, 140

Magma, average................167, 174, 175, 179

Magmas, distribution of ................166, 172

Marecocco.........................19, 20, 21

Martinal vicose-ciminose :

Analysis of ..........................72, 147

Description of ..........................71, 73

Melilitic leucitite, analysis of............139, 147

Methods of analysis........................ 10

Minor constituents, determination of ......18, 60

Missoural albanose........................ 130

Missourite, analysis of ................... 131

Mode, relation of norm to.................. 154

Monfinal shoshonose:

Analysis of ..........................88, 147

Description of ......................88, 90

Montana ..............51, 75, 127, 131, 169, 177

Monte Amiata.......................1, 158, 162

Monte Bisenzo.....................45, 99, 102

Monte Calveglia........................ . 45

Monte Calvario...........................1, 6

Monte Catini............................ 1

Monte Cavallo........................101, 102

Monte Cavo..........................6, 132

Monte Ciliano........................57, 65

Monte Cimino..................5, 24, 57, 63, 65

Monte di Cuma..................23, 24, 26, 29

Monte di Procida...................26, 27, 29

Monteflascone........4, 114, 124, 125, 127, 128, 140

Monte Fogliano........................5, 92, 94

Monte Jugo ...........................124, 125

Monte Levo ............................. 49

Monte Nuovo........................23, 24, 26

Monte Pallanzana .......................... 61

Monte Rado........................131, 132, 137

Monte Raschio .............................. 121

Monte Rotaro...............8, 21, 26, 27, 28, 29

Monte San Antonio.....................36, 92

Monte Santa Croce .................7, 88, 90, 165

Monte San Vito ........................ 6

Monte Somma............8, 105, 107, 116, 144, 165

Monte Tabor............................ 8, 26

Monte Valentino....................... 61

Monte Venere .................5, 6, 7, 69, 70, 163

Monte Vico......5, 23, 24, 25, 26, 36, 39, 41, 59, 61

Monte Vulture.......................... 1

Mount Vesuvius .........8, 104, 105, 107, 116, 165 Monzonose:

Analysis of ........................ 75,147

Description of........................74, 78

Occurrence of .....................78, 163, 165

Necrolite............................... 57

Nephelite-syenite, analysis of............47, 51 Nordmarkose-phlegrose:

Analysis of ........................20, 23, 147

Description of.....................19, 21, 22

Occurrence of.........................21, 26 
Norm and mode, relations of............. 154

Noselite, disuse of, in norm............... 15

Obsidian............................... 27

Olibano................................ 21

Orchi $\ldots \ldots \ldots \ldots \ldots \ldots \ldots \ldots \ldots \ldots \ldots . .26,40,83,84$

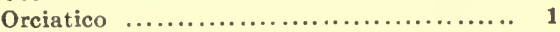

Oriolo ...........................49, 121, 123

Orvietal auruncose :

Analysis of.........................86, 147

Description of ...................... 85,87

Orvietal vicose:

Analysis of.........................101, 147

Description of ....................100, 102

Orvieto...........4, 70, 87, 94, 101, 102, 125, 161

Osteria del Tavolato...................51, 53

Ouachitite, analysis of .................. 127

Paglial procenose-pulaskose:

Analysis of ........................43, 147

Description of ............ ........41, 46

Pallanzanal vulsinose, description of ....... 40

Panza.................................. 26

Peperino.............................55, 57

Petrisco............................... 41

Petrographic province, use of term .......... v

Phlogrean Fields...8, 21, 23, 24, 26, 29, 31,

$33,42,43,75,78,165$

Phlegrose:

Analysis of....

$20,23,147$

Description of

$19,22,27$

Occurrence of ............21, 26, 161, 162, 163, 165

Phonolitic trachyte:

Analysis of .....

23,147

Description of .......................... 22

Piannra................................... 26

Pianural phlegrose....................... 26

Piperno................................. 26

Pofi ............................. 7, 114, 135, 137

Poggio Cavaliere.................74, 75, 76, 78

Poggio Cotognola.......................97, 99

Poggio Muratella......................47, 49

Poggio Tondo............................. 49

Porano.................................. 102

Portici................................ 120

Preta................................... 122

Proceno........................42, 43, 44, 45

Procenose-pulaskose:

Analysis of ........................43, 147

Description of .......................41, 46

Occurrence of.........................45, 161

Procida............................... 8

Progression of types..................... 169

Pulaskose:

Analysis of........................43, 147

Description of.......................41, 46

Occurrence of..........................45, 161

Punto di Castiglione..................... 26

Quartz, rarity of...................... 159

Radicofani.............................. 88

Rare earths, occurrence of................. 42

Regional progression of types............... 169

Rocea di Papa ..........................113, 114
Rocca Monfina ....................... 7, 90

Roccastrada............................. 1

Rock types, table of ..................... 14

Romal albanose:

Analysis of ........................131, 147

Description of .....................27, 29

Romal Vesurose:

Analysis of .......................... 122

Description of ......................... 121

Ronciglione............................ $\$ 1$

Rotaral phlegrose:

Analysis of .........................28, 147

Description of.......................27, 29

Rotondella.........................43, 45

Sabatinal beemerose:

Analysis of ........................47, 147

Description of ......................46, 49

Sabatinian District... 5, 47, 49, 94, 97, 99, $106,110,114,121,122,132,137,140,163,167$

Saccal albanose:

Analysis of ..................... 135, 147

Description of .....................133, 138

Sacco River............................. 7

San Francesco......................... 129

San Giovanni di Bieda..................... 61

San Lorenzo............................. 132

San Martino........................ 39, 72, 73

San Rocco..............................36, 39

Santa Maria di Galera....................... 110

Santa Trinita.......................... 94

Sassi Lanciati........................... 122

Scalal vesurose-braccianose:

Analysis of.........................118, 147

Description of .....................117, 120

Scanella............................21, 26

Selva del Lamone....................... 4

Serial chemical characters..............148, 150

Shoshonose:

Analysis of ...................... 88, 147

Description of ......................8, 90

Occurrence of........................90, 165

Sodalite, disuse of, in the norm............ 15

Sommal braccianose, description of......... 107

Sorianal harzose:

Analysis of . .........................56, 147

Description of ........................54, 58

Soriano.............................57, 65

Succession of types...................... 176

Tavolatal janeirose-appianose:

Analysis of .........................51, 147

Description of.......................... 50,54

Tavolatite:

Analysis of ..........................51, 147

Description of ......................... 50

Tavolato ............................ $51, \quad 53$

Teanal ciminose-auruncose :

Analysis of..........................83, 147

Description of .......................82, 85

Teano.............................26, 83, 84

Thenardite, $n$ se of, in the norm............ 15

Ticchiena.........................134, 135, 137 
Tolfa

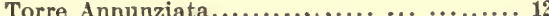

Torre del Greco.........................118, 120

Toscanella ...........................86, 87

Trachyandesite.......................57, 66

Trachydolerite, analysis of................ 75

Trachyte:

Analysis of .................20, 23, 28, 75, 147

Description of ..................19, 22, 27, 74

Trebianello ............................. 110

Trevignano.............................132, 140

Tuoro ................................ 84

Tuscan Region............1, 2, 3, 145, 158, 162, 170

Tusculum .............................. 140

Type, definition of ........................ 12

Types :

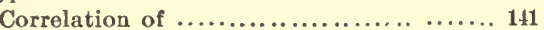

Descriptions of.........................9, 12

Progression of.......................... 169

Succession of ........................ 176

Table of..............................14, 147

Valentino.............................. 125

Venanzite.............................. 159

Venetian Region........................ 1

Vesbal braccianose :

Analysis of ........................104, 147

Description of ......................103, 106

Vesbian Volcano. See Vesuvius,

Vesurius......8, 104, 105, 107, 116, 118, 120, 159, 165

Vesurose:

Analysis of........................... 122

Description of......................... 121

Error in regard to name..............104, 123

Occurrence of............122, 161, 163, 164, 165

Vesuvose-braccianose:

Analysis of...

118,147

Description of

117,120
Vetralla................................59, 61

Vicarello................................. 49

Vicoite................................ 95

Vicose:

Analysis of $\ldots \ldots \ldots \ldots \ldots \ldots \ldots \ldots . .92,97,101,147$ Description of ............91, 95, 96, 99, 100, 102 Occurrence of..........94, 99, 102, 161, 163, 165

Vicose-ciminose:

Analysis of ........................72, 147

Description of.....................71, 73

Vico Volcano....5, 22, 23, 25, 26, 36, 39, 41, $61,73,78,81,92,94,157,162,163$

Viterbal vulsinose:

Analysis of ...........................36, 147

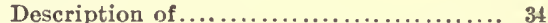

viterbite............................... 40

Viterbo.....................24, 40, 56, 57, 73

Viterboid habit.......................... 35

Vulsinian District... 1, 3, 31, 33, 45, 61, 67, $70,86,94,99,101,102,110,114,122,124$, $125,128,131,132,137,140,161,166,167$

Vulsinite:

Analysis of .................... 31, 59,75, 147

Description of.....................30, 58, 74

Vulsinose :

Analysis of.........................31, 36, 147

Description of ....................... 30, 34, 40

Occurrence of........33,39,41, 161, 162, 163, 165

Vulsinose-ciminose:

Analysis of .......................... 59,147

Description of $\ldots \ldots \ldots \ldots \ldots \ldots \ldots \ldots . \ldots, 62$

Occurrence of .......................... 61

Vulsinose-pulaskose, analysis of .........43, 147

Zale...................................... 21 



-

I 


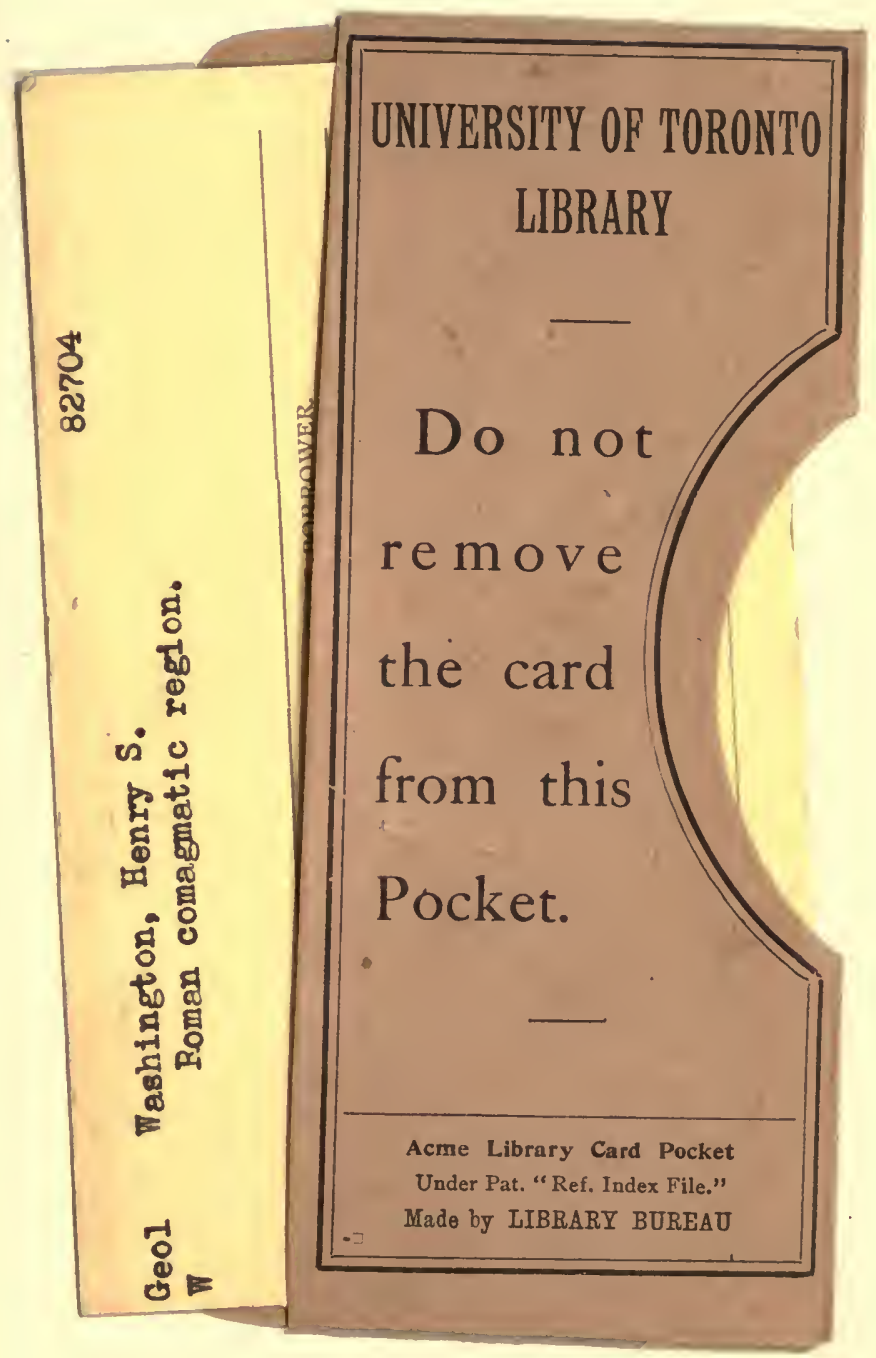


